\title{
CALCÁRIO, NITROGÊNIO E ENXOFRE PARA A RECUPERAÇÃO DO CAPIM-BRAQUIÁRIA CULTIVADO EM SOLO PROVENIENTE DE UMA PASTAGEM DEGRADADA
}

\author{
ROSANE CLÁUDIA RODRIGUES
}

\begin{abstract}
Dissertação apresentada à Escola Superior de Agricultura "Luiz de Queiroz", Universidade de São Paulo, para obtenção do título de Mestre em Agronomia, Área de Concentração: Ciência Animal e Pastagens.
\end{abstract}

PIRACICABA

Estado de São Paulo - Brasil

Julho - 2002 


\title{
CALCÁRIO, NITROGÊNIO E ENXOFRE PARA A RECUPERAÇÃO DO CAPIM-BRAQUIÁRIA CULTIVADO EM SOLO PROVENIENTE DE UMA PASTAGEM DEGRADADA
}

\author{
ROSANE CLÁUDIA RODRIGUES
}

Zootecnista

Orientador: Prof. Dr. HERBERT BARBOSA DE MATTOS

Dissertação apresentada à Escola Superior de Agricultura "Luiz de Queiroz", Universidade de São Paulo, para obtenção do título de Mestre em Agronomia, Área de Concentração: Ciência Animal e Pastagens.

PIRACICABA

Estado de São Paulo - Brasil

Julho - 2002 


\section{Dados Internacionais de Catalogação na Publicação (CIP)}

DIVISÃO DE BIBLIOTECA E DOCUMENTAÇÃO - ESALQ/USP

Rodrigues, Rosane Claúdia Calcário, nitrogênio e enxofre para a recuperação do capim-braquiária cultivado em solo proveniente de uma pastagem degradada / Rosane Claúdia Rodrigues. - Piracicaba, 2002.

$141 \mathrm{p}$.

Dissertação (mestrado) - - Escola Superior de Agricultura Luiz de Queiroz, 2002.

Bibliografia.

1. Calcário 2. Capim braquiária 3. Fertilizantes nitrogenados 4. Fertilizantes sulfatados I. Título

CDD 633.2

\section{"Permitida a cópia total ou parcial deste documento, desde que citada a fonte - $O$ autor"}


À Regina Célia de Carvalho Braga e família

\section{OFEREÇO}

À minha filha Júlia. 


\section{AGRADECIMENTOS}

À Deus pela proteção e força nos momentos difíceis.

À minha família e à Regina e Álvaro Braga pelo apoio em todas as etapas de minha vida.

Ao Professor Dr. Herbert Barbosa de Mattos, pela sua orientação, amizade e compreensão.

À FAPESP, pela bolsa de estudos e de pesquisa concedida.

Aos Professores Francisco Antônio Monteiro, Quirino A. C. Carmello, Ricardo Ferraz de Oliveira, pela atenção e colaboração no trabalho de pesquisa.

À Faculdade de Zootecnia e Engenharia de Alimentos/USP, na pessoa do Professor Valdo Herling e Marcos Ferraz, na realização de algumas análises.

Às funcionárias do Laboratório de Solos e Nutrição de Plantas - ESALQ, Lúcia, Nivanda, Ednéia, Sueli pela amizade e auxílio na execução das análises. Às bibliotecárias Eliane $\mathrm{M}^{\mathrm{a}}$. Garcia e Sílvia $\mathrm{M}^{\mathrm{a}}$. Zinsly, pela ajuda nas correções. Às minhas amigas Renata Carrijo, Laryssa Raquel Schmaltz Marques.

Aos amigos Walcylene Pereira, João de Deus, José Lavres Júnior, Waldeliza, Alexandre, Ana Clara Fayal, Michelle Costa, Maria del Carmen e Patrícia Sarmento pela amizade desenvolvida e bons momentos que me proporcionaram.

Aos estagiários em especial, Ricardo Bull, Thiago Maique e Dylnei Consumagno Neto pelo apoio na condução do experimento. 


\section{SUMÁRIO}

Página

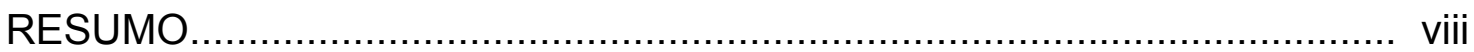

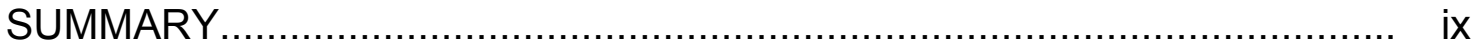

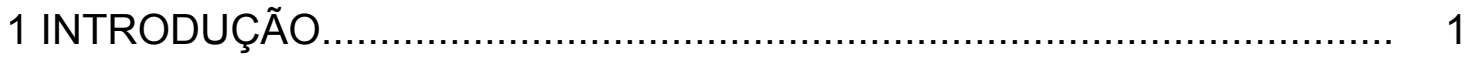

2 REVISÃO DE LITERATURA............................................................. 3

2.1 Brachiaria decumbens Stapf....................................................... 3

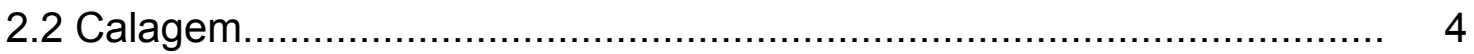

2.2.1 Origem da acidez do solo....................................................... 4

2.2.2 Alumínio como componente da acidez do solo................................ 5

2.2.3 Efeitos da acidez no solo........................................................... 5

2.2.4 Correção da acidez do solo....................................................... 6

2.2.5 Efeitos da calagem sobre a produção de plantas forrageiras ............. 8

2.3 Nitrogênio................................................................................ 9

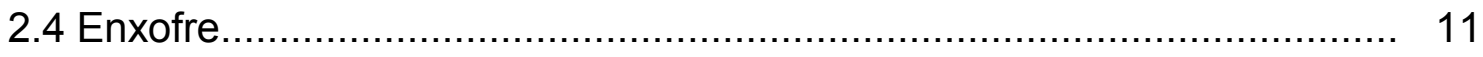

2.4.1 Relação nitrogênio : enxofre....................................................... 14

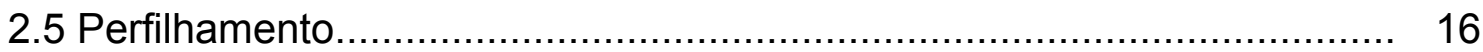

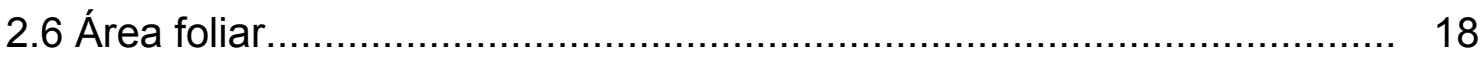

2.7 Estimativa do teor de clorofila em valor SPAD................................... 20

3 MATERIAL E MÉTODOS ............................................................. 23

3.1 Localização e espécie forrageira.................................................... 23

3.2 Doses de nitrogênio, enxofre e calcário e delineamento experimental. 23

3.3 Instalação e condução do experimento.............................................. 23

3.4 Determinação do número de perfilhos, estimativa do teor de clorofila, avaliação da área foliar.............................................................. 25

3.5 Produção de matéria seca.......................................................... 26 


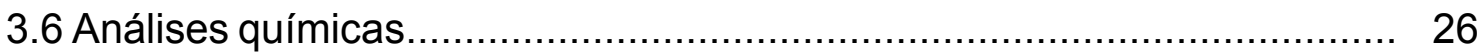

3.7 Análises estatísticas................................................................ 27

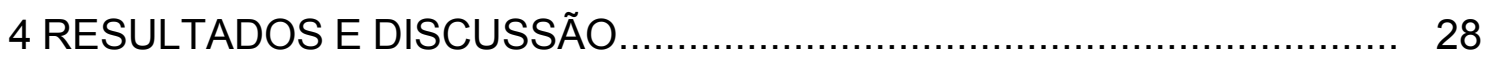

4.1 Produção de matéria seca da parte aérea.......................................... 28

4.2 Produção de matéria seca das raízes................................................... 34

4.3 Perfilhamento.......................................................................... 35

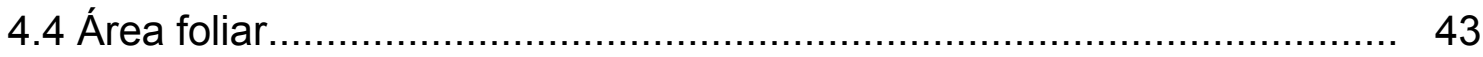

4.5 Estimativa do teor de clorofila através do valor SPAD ........................ 47

4.6 Concentração macronutrientes nos componentes da parte aérea.......... 48

4.6.1 Nitrogênio ............................................................................ 48

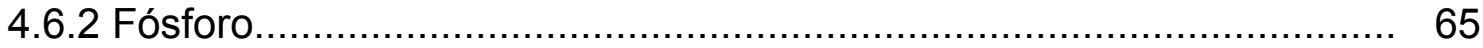

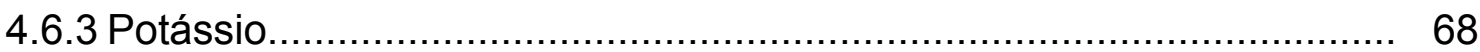

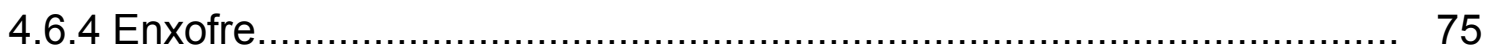

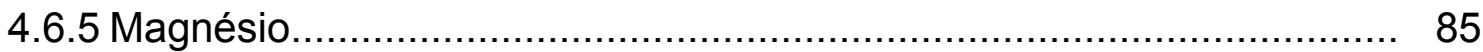

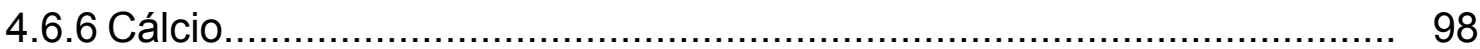

4.7 Concentração micronutrientes nos componentes da parte aérea............ 100

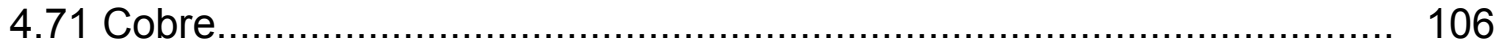

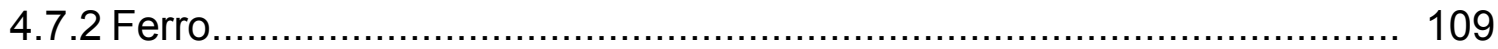

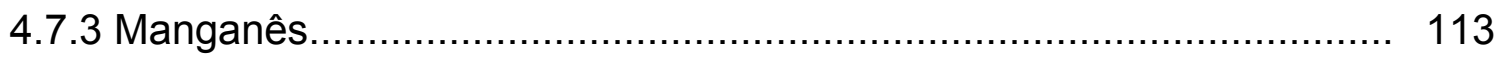

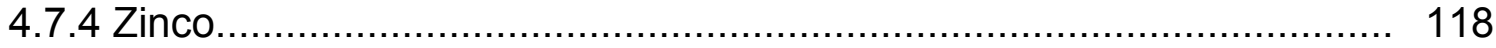

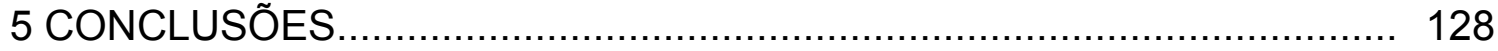

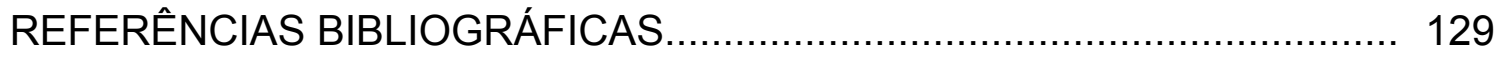




\title{
Calcário, nitrogênio e enxofre para a recuperação do capim- braquiária cultivado em solo proveniente de uma pastagem degradada
}

\author{
Autora: ROSANE CLÁUDIA RODRIGUES \\ Orientador: Prof. Dr. HERBERT BARBOSA DE MATTOS
}

\section{RESUMO}

O presente trabalho foi desenvolvido com o objetivo de avaliar as respostas da Brachiaria decumbens Stapf, cultivada em solo proveniente de uma pastagem degradada. O experimento foi desenvolvido em casa-devegetação do Departamento de Ciências Biológicas da Escola Superior de Agricultura "Luiz de Queiroz"/USP. O solo utilizado foi classificado como Neossolo Quartzarênico e foi coletado numa profundidade de 0 a $20 \mathrm{~cm}$. Após a coleta esse solo foi seco, homogeneizado, pesado e colocados em sacos plásticos, juntamente com as respectivas doses de calcário e depositados em vasos com capacidade de $10 \mathrm{~kg}$, onde permaneceram por um período de 60 dias. Os tratamentos consistiram de quatro doses de nitrogênio $(0,180,630$ e $1080 \mathrm{mg} \mathrm{kg}^{-1}$ de solo), quatro doses de calcário $(0,1587,6,3175,2$ e 4762,8 mg $\mathrm{kg}^{-1}$ de solo) e três doses de enxofre (0, 108 e $216 \mathrm{mg} \mathrm{kg}^{-1}$ de solo). Empregouse um esquema fatorial $4 \times 4 \times 3$ perfazendo 48 combinações, as quais foram distribuídas segundo o delineamento experimental de blocos casualizados, com três repetições. No momento do plantio efetuou-se uma adubação com fósforo e potássio, micronutrientes (cobre e zinco) e enxofre. Aos treze dias após o 
plantio realizou-se a adubação com o nitrogênio. Foram realizados dois cortes e um dia antes de cada corte efetuou-se avaliações do teor de clorofila. Após o corte o material coletado foi separado em folhas emergentes, lâminas de folhas recém-expandidas, lâminas de folhas maduras e colmos mais bainhas e foi realizada a leitura da área foliar dos três primeiros. Em seguida esse material foi colocado em estufa de circulação forçada de ar a $65^{\circ} \mathrm{C}$ por 72 horas para determinar a matéria seca de cada componente da parte aérea e, esse mesmo procedimento foi feito para as raízes após serem lavadas. O material depois de pesado foi moído em moinho tipo Wiley e levado ao laboratório para a determinação de macro e micronutrientes. Realizou-se também, a contagem de perfilhos. Os resultados evidenciaram efeito significativo $(P<0,05)$ das doses de nitrogênio no primeiro corte, e significância para a interação entre enxofre e nitrogênio para a produção de matéria seca da parte aérea da planta, no primeiro e segundo crescimentos. Quanto à produção de matéria seca das raízes, verificou-se efeito significativo $(P<0,05)$ somente para as doses de nitrogênio. No perfilhamento da forrageira houve significância para a interação entre as doses de enxofre, nitrogênio e calcário, no segundo corte. Também houve significância $(P<0,05)$ para as doses de enxofre e nitrogênio no valor SPAD e interação nitrogênio e calcário na área foliar. Na concentração de macro e micronutrientes da planta houve significância $(P<0,05)$ das doses de nitrogênio, enxofre e calcário e interação entre nitrogênio e enxofre e nitrogênio e calcário em alguns componentes da parte aérea. 


\title{
LIME, NITROGEN AND SULFUR FOR SIGNAL GRASS RECOVERY IN A SOIL FROM A DEGRADED PASTURE
}

\author{
Author: ROSANE CLÁUDIA RODRIGUES \\ Adviser: Prof. Dr. HERBERT BARBOSA DE MATTOS
}

\section{SUMMARY}

The present work was carried out with the objective of evaluating responses of Brachiaria decumbens Stapf. grown in a soil from a degraded pasture. The experiment was conducted in a grenhouse in the Departamento de Ciências Biológicas at the "Escola Superior de Agricultura Luiz de Queiroz" - USP. The soil was classified as an Entissol and it was collected from a layer of 0 to $20 \mathrm{~cm}$. The pots were filled with $10 \mathrm{~kg}$ of this soil and lime rates were incubated for 60 days. The experimental arrange was a $4 \times 4 \times 3$ factorial with nitrogen $\left(0,180,630\right.$ and $\left.1080 \mathrm{mg} \mathrm{kg}^{-1}\right)$, lime $(0,1587.6,3175.2$ and $\left.4762.8 \mathrm{mg} \mathrm{kg}^{-1}\right)$ and sulfur (0, 108 and $\left.216 \mathrm{mg} \mathrm{kg}^{-1}\right)$, and it was used a randomized complete block design, with three replications. Fertilization with $\mathrm{P}, \mathrm{K} \mathrm{Cu}, \mathrm{Zn}$ and $\mathrm{S}$ was done at sowing, and $\mathrm{N}$ was applied 13 days that. Plants was harvested twice, and plant tops was separated in emergent leaves $(E L)$, laminae of recently expanded leaves $(R L)$, laminae of mature leaves $(\mathrm{ML})$ and culms plus sheaths (CS), Leaf area was determined by measuring 
EL, LR and ML. SPAD values (chlorophyll content) were evaluated one day before each harvests. The collected material was dried at $65{ }^{\circ} \mathrm{C}$ during 72 hours in an oven with circulating air. The root system was collected and washed following the second harvest. Nutrient concentrations in the forage dry matter and roots were determined after weighting and grinding the samples. Results showed significant effect $(P<0.05)$ for nitrogen supply in the first harvest, and significant interaction for sulfur nitrogen on plant tops dry matter in the first and the second harvests. Roots dry matter had significant $(P<0.05)$ effect for nitrogen rates. Significancies were observed for nitrogen nitrogen $X$ sulfur interaction for SPAD values, for nitrogen $X$ lime for leaf area and for lime $X$ nitrogen $X$ sulfur for plant tillering at second harvest. The nitrogen, sulfur and lime had significant effects on nutrients concentrations, as well as by interaction of nitrogen $X$ sulfur and nitrogen $X$ lime for some parts of plant tops. 


\section{INTRODUÇÃO}

A exploração pecuária no Brasil Central está baseada no potencial de produção de forragens, visto que a pastagem é a mais importante, quando não a única fonte de alimentação de bovinos e, indubitavelmente a mais econômica. Entretanto, os rebanhos bovinos são mantidos, na maioria das vezes, em pastagens implantadas sem qualquer tipo de tecnologia e nos primeiros anos as mesmas apresentam alta capacidade de suporte. Porém, com o passar dos anos, vão se degradando em decorrência, principalmente, da queda na fertilidade dos solos e do manejo inadequado, comprometendo o desenvolvimento dessa atividade e contribuindo para os baixos índices zootécnicos obtidos em nosso País.

Dentro desse contexto, deve-se considerar a importância das gramíneas do gênero Brachiaria que, ocupam uma posição de destaque na pecuária brasileira por se adaptarem a solos de baixa fertilidade. Atualmente, estima-se que, aproximadamente, 40 milhões de hectares de pastagens no Brasil Central sejam do gênero Brachiaria. Todavia, a tradição extrativista dos agropecuaristas tem levado essas pastagens à degradação. Dessa forma, torna-se necessário buscar formas de recuperá-las, sendo a adubação uma das opções mais interessantes.

$\mathrm{Na}$ maioria dos solos do Brasil Central, em função de sua acidez elevada, a adubação por si só não supre efetivamente os nutrientes às pastagens, tornando-se necessária a adoção de medidas para corrigir tal acidez. Nesse ponto, a calagem visa propiciar condições favoráveis para que as 
mesmas melhorem sua produtividade, assim como proporcionar melhor aproveitamento de nutrientes primordiais para o desenvolvimento das forrageiras fornecidos pela adubação, e fornecer $\mathrm{Ca}$ e $\mathrm{Mg}$.

Um outro elemento importante é o nitrogênio, pois ele é o principal constituinte das proteínas, participa na formação de compostos orgânicos além de possuir participação ativa na estrutura vegetal. Portanto, se não houver nitrogênio suficiente no solo para atender a demanda da planta seu crescimento será lento, com poucos perfilhos, e o teor de proteína da forragem produzida torna-se insuficiente para atender às exigências dos animais.

O enxofre, por sua vez, tem uma importância relevante para as plantas pois participa na síntese de proteínas, além de todas as proteínas vegetais 0 apresentam em sua composição. A deficiência desse elemento é maior em solos degradados, o que compromete ainda mais o desenvolvimento e a qualidade das plantas forrageiras.

O propósito deste trabalho foi o de avaliar as respostas da Brachiaria decumbens Stapf., cultivada em um solo proveniente de uma pastagem degradada, às aplicações de doses de enxofre, nitrogênio e calcário quanto à produção de matéria seca, número de perfilhos, teor de clorofila estimado através da leitura SPAD, área foliar e concentração de macro e micronutrientes nos componentes da planta. 


\section{REVISÃO DE LITERATURA}

\subsection{Brachiaria decumbens Stapf.}

A Brachiaria decumbens tem como principal centro de origem a Àfrica tropical e é de ocorrência natural nas savanas africanas. É uma das gramíneas que mais tem sido utilizada para a formação de pastagens no mundo. No Brasil há dois cultivares de Brachiaria decumbens. O primeiro conhecido como cultivar IPEAN, introduzido pelo Instituto de Pesquisa Agropecuária do Norte em Belém -PA em 1952. Esse cultivar apresenta crescimento mais decumbente, com raízes nos nós e folhas muito pilosas. O segundo é proveniente da Austrália, porém de origem Africana e teve seu desenvolvimento inicial no Estado de São Paulo. Esse cultivar é mais robusto, de crescimento sub-erecto e com folhas menos pilosas. É conhecido como cultivar Basilisk ou cultivar Australiana (Alcântara, 1987).

Cultivada em todas as regiões do país, essa planta forrageira destaca-se nas grandes extensões de áreas da região Central. A sua disseminação deu-se de maneira acentuada devido à boa produção e germinação de sementes, alta agressividade na competição com a vegetação nativa e elevada disseminação pela semeadura natural, além de ser uma espécie tolerante à seca. O capimbraquiária, muito usado nos cerrados, foi o primeiro capim a ser plantado em larga escala, embora se desenvolva melhor em regiões tropicais úmidas onde as estações de seca não duram mais que quatro meses (Alcântara, 1987). As pastagens formadas com essa planta forrageira freqüentemente apresentam 
redução gradativa de produtividade após estabelecimento (Carvalho et al., 1991).

Segundo Soares Filho et al. (1992), a maioria das pastagens de braquiária no Estado de São Paulo encontram-se em estado de degradação e apontam como causas mais comuns para esse declínio, o esgotamento da fertilidade do solo e o manejo inadequado.

\subsection{Calagem}

\subsubsection{Origem da acidez dos solos}

A capacidade de troca de cátions medida a $\mathrm{pH} 7$ tem valor constante. Assim o solo será tanto mais ácido, quanto menos dessa capacidade de troca for ocupada por cátions básicos tais como cálcio, magnésio, potássio e sódio. A acidificação consiste na remoção dos cátions básicos do complexo de troca catiônica (Raij, 1981). Segundo Correia (1981), na origem da acidez do solo, o $\mathrm{H}^{+}$surge inicialmente da reação do $\mathrm{CO}_{2}$ do ar atmosférico com a água, além da reação de nitrificação do $\mathrm{NH}_{4}{ }^{+}$.

$\mathrm{Na}$ reação do $\mathrm{CO}_{2}$ do ar atmosférico com a água, além de ser liberado próton $\mathrm{H}^{+}$, há produção também de ânion bicarbonato, conforme demonstrado na fórmula: $\mathrm{CO}_{2}+\mathrm{H}_{2} \mathrm{O} \leftrightarrow \mathrm{HCO}_{2}^{-}+\mathrm{H}^{+} \leftrightarrow \mathrm{CO}_{3}^{-}+\mathrm{H}^{+}$.

O ânion bicarbonato é um dos principais fatores de arraste de bases em profundidade, sendo tal reação mais importante em solos de $\mathrm{pH}$ elevado, e pouco expressiva em solos ácidos como os encontrados na maior parte do Brasil (Quaggio, 1986).

Outro aspecto relevante no processo de acidificação dos solos consiste no deslocamento dos cátions para camadas mais profundas do perfil. Para isso ser possível, torna-se necessário a presença de íons que possuam o mesmo sinal de cargas das partículas do solo, designados de co-íons, os quais têm facilidade de movimento através de um fluxo descendente de água. Nessa situação, os ânions ligam-se aos cátions presentes na solução do solo, gerando 
uma neutralização mútua das cargas e tornando possível, então, o movimento dos cátions, que até então possuíam cargas positivas, e passam a ter carga nula. Ao se ligarem aos ânions ocorre a interrupção da atração eletrolítica entre as partículas do solo, propiciando a sua lixiviação (Quaggio, 1986).

\subsubsection{Alumínio como componente da acidez do solo}

O processo natural ou artificial de acidificação do solo faz com que a estabilidade química dos compostos de alumínio seja reduzida, ocorrendo aumento da solubilidade dos minerais, de forma que parte do alumínio total se torne solúvel, podendo ocorrer em concentrações potencialmente tóxicas para as plantas. A atividade desses prótons faz com que o alumínio se desloque das lâminas das argilas tornando-se trocável ou solúvel. Dessa maneira, a medida que os solos são lixiviados de íons $\mathrm{Ca}^{+2}, \mathrm{Mg}^{+2}, \mathrm{~K}^{+}$, e $\mathrm{Na}^{+}$e os minerais de argila vão solubilizando, passam a predominar os íons $\mathrm{H}^{+}$e $\mathrm{Al}^{3+}$, caracterizando a transformação de um solo originalmente neutro, com seu complexo coloidal ocupado por bases, em solo ácido pela perda de bases trocáveis e acúmulo relativo de Al e H (Defelipo, 1990).

\subsubsection{Efeitos da acidez no solo}

Arnon \& Johnson (1942) citados por Malavolta (1980), realizaram experimentos para verificar o efeito direto do $\mathrm{pH}$, onde foram utilizados $\mathrm{o}$ tomateiro, a alface e a grama bermuda. Concluíram que, em valores extremos de $\mathrm{pH}$, as plantas morreram ou apresentaram acentuada diminuição do crescimento. Em pH 3,0 a absorção de macronutrientes foi drasticamente reduzida, havendo, em alguns casos perdas de $\mathrm{P}, \mathrm{K}$, e $\mathrm{Mg}$. $\mathrm{Em} \mathrm{pH} \mathrm{9,0} \mathrm{houve}$ acentuada queda na absorção de $\mathrm{P}$. Em pH 4,0 houve diminuição dos prejuízos devido ao cálcio, pois segundo esses autores, o cálcio estimula a absorção de 
potássio e, aparentemente, diminui a competição do hidrogênio com os demais cátions. $\mathrm{O}$ crescimento máximo foi verificado entre $\mathrm{pH} 6$ e 7.

Acredita-se que nas condições de solo o efeito principal do $\mathrm{pH}$ seja o indireto, ou seja, a variação na acidez ou alcalinidade está associada com variações na disponibilidade de elementos químicos, nutrientes ou não (Malavolta, 1980).

Malavolta et al. (1989) afirmaram que, de modo geral, as maiores disponibilidades em relação ao pH estão associadas à maiores concentrações na solução do solo e finalmente maior capacidade de absorção da planta.

\subsubsection{Correção da acidez do solo}

A calagem é uma prática muito antiga, usada pelos gregos e os bárbaros gauleses, os quais aplicavam calcário ao solo de diversas formas para aumentar as colheitas (Malavolta, 1980). Entretanto, a sua recomendação, principalmente com base na análise do solo, tem sido até hoje motivo de controvérsia nos meios científicos.

A correção da acidez, ou princípio da calagem, baseia-se na troca iônica, capacidade que o solo possui, quando em presença de um sal, de reagir e trocar cátions. Defelipo (1990) cita que, apesar de muitos materiais terem a capacidade de permutar seus cátions com o solo, para ser considerado corretivo, o material deve possuir certos requisitos:

Efetuar reação: $\circ \mathrm{H}^{+}$pode estar retido no solo com uma força tal, que não permite que este seja trocado com o sal. Ou seja, o corretivo deve apresentar poder de efetuar a troca.

Produto da reação: uma vez efetuada a troca o corretivo recebendo o $\mathrm{H}^{+}$deve formar um composto que não seja tóxico ou danoso às culturas. O composto resultante deve ser um produto inerte ou solúvel que possa ser lixiviado com a água. 
Elemento essencial: o corretivo fornece à micela do solo um cátion e este deve ser um elemento essencial às plantas. Dessa forma, além de corrigir a acidez estará fertilizando o solo.

O calcário tem sido o produto mais freqüentemente utilizado como corretivo, face a freqüência e abundância com que ocorre na natureza. Porém, outros materiais também podem ser utilizados tais como: óxido de cálcio e de magnésio (cal virgem) obtidos pela calcinação do calcário; hidróxidos de cálcio e de magnésio, obtidos pela hidratação dos seus respectivos óxidos; e calcário calcinado, obtido pela calcinação parcial do calcário. Também são usados como corretivos as escórias de siderurgias, em que os componentes principais são os silicatos de cálcio e de magnésio e que apresentam ainda teores relativamente altos de micronutrientes (De-Polli, 1988).

A recomendação de calagem em pastagens é muito variável, pois depende da planta forrageira bem como da região em que esta encontra-se (Vitti \& Luz, 1997). No Estado de São Paulo e principalmente no Centro Oeste, o critério de calagem utilizado é baseado no método de saturação por bases, proposto por Raij (1981), o qual é realizado através da seguinte expressão:

\section{NC $(\mathrm{t} / \mathrm{ha})=\left(\mathrm{V}_{2}-\mathrm{V}_{1}\right) \mathrm{T} / 10 \mathrm{PRNT}$.}

Onde: $\mathrm{NC}=$ necessidade de calagem (t/ha) para a profundidade de $0-20$ $\mathrm{cm}, \mathrm{V}_{1}=$ saturação por bases atual do solo na camada de $0-20 \mathrm{~cm}(\%), \mathrm{V}_{2}=$ saturação por bases desejada para uma determinada pastagem (\%), $\mathrm{T}=$ capacidade de troca catiônica $\left(\mathrm{mmol}_{d} / \mathrm{dm}^{3}\right)$ e PRNT = poder relativo de neutralização total do calcário (\%).

Os valores de $V_{1}$ e $T$ são fornecidos através da análise química da amostra de solo, o PRNT depende do calcário e o valor de $V_{2}$ a ser utilizado é dependente da planta forrageira a ser cultivada. Esse é o critério mais utilizado em todo o Brasil. Os outros critérios são baseados nos teores de Ca e Mg, no Al e Ca + Mg trocáveis do solo (Minas Gerais) e tampão SMP (Rio Grande do Sul e Santa Catarina). 


\subsubsection{A calagem na produção de plantas forrageiras}

A calagem promove a diminuição da acidez dos solos, através da insolubilização de elementos tóxicos, principalmente alumínio e manganês; aumento dos teores de cálcio e magnésio e o favorecimento das propriedades físicas do solo, pela ação floculante do cálcio (Raij \& Quaggio, 1985).

Num experimento em casa de vegetação, Siqueira et al. (1980), trabalharam com um Latossolo Vermelho-Amarelo distrófico álico, inicialmente com $84 \%$ de saturação por $\mathrm{Al}$, aplicando 0; 0,8; 1,3 e 4,0 t ha- ${ }^{-1}$ de $\mathrm{CaCO}_{3}$ com três gramíneas, entre elas Brachiaria decumbens. Observaram aumento significativo no peso da parte aérea das três gramíneas até a dose de $0,8 \mathrm{t} \mathrm{ha}^{-1}$. Conclusões semelhantes para a Brachiaria decumbens foram obtidas por Pereira (1986) e Sanzonowicz et al., (1987) para as dose de $2,5 \mathrm{t} \mathrm{ha}^{-1}$ de calcário em Latossolo Vermelho com vegetação de campo limpo e 3,0 $\mathrm{t} \mathrm{ha}^{-1} \mathrm{em}$ Latossolo Vermelho-escuro distrófico, respectivamente.

Lopes (1984) apontou a necessidade de calagem para elevar o $\mathrm{pH}$ dos solos de cerrado a valores acima de 5,5 para ativar a formação de cargas negativas na fração orgânica do solo, aumentar a capacidade de troca catiônica e reduzir o potencial de perdas de cátions por lixiviação.

Em um experimento realizado em casa de vegetação para determinar a dose para elevar a saturação por base que permitiria a máxima produção de forragem para Brachiaria brizantha cv. Marandu, Panicum maximum cv. IZ-1 e algumas espécies de leguminosas, Premazzi (1991), observou que a máxima produção de matéria seca foi obtida com $43 \%$ e $47 \%$ de saturação por base para a Brachiaria brizantha e Panicum maximum, respectivamente. 


\subsection{Nitrogênio}

O nitrogênio é considerado, dentre os fatores de produção, como um dos nutrientes mais importantes e de alta contribuição, pois constitui o principal nutriente para a manutenção da produtividade das gramíneas forrageiras.

Apesar desse elemento ser abundante na atmosfera na forma de $N_{2}$, está presente em pequenas quantidades na maioria dos solos. Esse elemento participa ativamente na síntese de compostos orgânicos que formam a estrutura do vegetal, tais como: aminoaçúcares, aminas, amidas, vitaminas, pigmentos, aminoácidos, proteínas, ácidos nucléicos e molécula de clorofila (Malavolta, 1980; Mengel \& Kirkby,1987). Além disso, é responsável pelo aparecimento e desenvolvimento dos perfilhos, tamanho das folhas e dos colmos (Nabinger, 1997; Werner, 1986). Assim, se houver baixa disponibilidade de nitrogênio no solo, as plantas manifestarão menor crescimento, reduzindo a quantidade de perfilhos e tamanho das folhas e, como conseqüência, redução no teor de proteína bruta, tornando a forragem deficiente para a nutrição animal.

O nitrato e o amônio são as formas de nitrogênio mais absorvidas pelas raízes e transportadas no xilema das plantas superiores. Parte do amônio é incorporado em compostos orgânicos ainda nas raízes, enquanto o nitrato é reduzido a amônio para fazer parte dos esqueletos carbônicos das plantas. $\mathrm{O}$ nitrato é muito móvel na planta e pode também ser armazenado nos vacúolos das células das raízes, colmos e orgãos de reserva (Marschner, 1995). De acordo com o autor, a acumulação do nitrato no vacúolo é fundamental para o balanço de cátions e ânions assim como para o processo de osmoregulação. Mas, para que isso ocorra, é necessário a redução do nitrato a amônia para que haja incorporação do nitrogênio em estruturas orgânicas nas plantas.

Segundo Fernandes \& Rossielo (1986), uma grande parte do amônio absorvido pode ser incorporado em compostos orgânicos nas raízes e ser armazenado nos vacúolos de suas células. 
A adubação nitrogenada em pastagens há muito vem sendo estudada pela comprovada importância que esse nutriente tem sobre a produção das plantas forrageiras. Vicente-Chandler (1973), estudando o efeito de doses de nitrogênio em sete capins tropicais, verificou uma ampla faixa de resposta em produção de matéria seca à aplicação de nitrogênio, sendo que o capim gordura (Melinis minutiflora Beauv.) obteve sua máxima produção na dose de $224 \mathrm{~kg} \mathrm{ha}^{-1} \mathrm{ano}^{-1}$. Para o capim-napier (Pennisetum purpureum Schum.) a máxima produção ocorreu na dose $1729 \mathrm{~kg} \mathrm{ha}^{-1} \mathrm{ano}^{-1}$. O autor mencionou que as gramíneas tropicais podem responder a doses de nitrogênio de até $1800 \mathrm{~kg}$ $\mathrm{ha}^{-1} \mathrm{ano}^{-1}$, sendo que essas respostas ocorrem de forma diferenciada, dependendo da espécie.

Harding \& Grof (1978), estudando gradientes de nitrogênio em Brachiaria decumbens, constataram como ótima a dose de $365 \mathrm{~kg} \mathrm{ha}^{-1} \mathrm{ano}^{-1} \mathrm{em}$ termos de produção de forragem e aproveitamento de nitrogênio, Estudos semelhantes desenvolvidos pelo CIAT (1978) mostraram que, no primeiro ano o capim-braquiária respondeu positivamente até a dose de nitrogênio de $400 \mathrm{~kg}$ de ha-1, enquanto que para o capim colonião esse valor foi de $200 \mathrm{~kg} \mathrm{ha}^{-1}$.

Em pastagens estabelecidas há mais de cinco anos, Sanzonowicz (1986) relatou que o nitrogênio foi o nutriente que mais limitou a produção de forragem das pastagens de Brachiaria ruziziensis e Brachiaria decumbens. Pereira (1986) obteve resposta diferencial na produção de matéria seca de quatro braquiárias submetidas a cinco doses de nitrogênio em solos de cerrado. A Brachiaria decumbens e a Brachiaria ruziziensis tiveram as maiores produções de forragem em todas as doses de nitrogênio, exceto na ausência de adubação nitrogenada, situação em que a Brachiaria decumbens cv. IPEAN foi a mais produtiva.

Trabalhando com Brachiaria decumbens e Brachiaria brizantha em Latossolo Vermelho-Amarelo, Alvim et al. (1990) constataram que todos os acessos de Brachiaria estudados responderam até a dose de nitrogênio de 150 $\mathrm{kg} \mathrm{ha}^{-1}$ e não apresentaram diferenças entre si na produção de forragem 
quando a dose foi $75 \mathrm{~kg} \mathrm{ha}^{-1}$. Na ausência desse elemento, os acessos de Brachiaria decumbens foram os mais produtivos. Carvalho et al. (1991) avaliaram as respostas de gramíneas forrageiras à adubação nitrogenada e constataram incrementos marcantes na produção de matéria seca da Brachiaria decumbens quando esta foi submetida a doses crescentes de nitrogênio até o valor de $400 \mathrm{~kg} \mathrm{ha}^{-1} \mathrm{ano}^{-1}$.

As folhas são as partes de primeira oferta aos herbívoros, dessa maneira, sua composição química torna-se primordial para a determinação do valor nutritivo. A qualidade e aceitação de forragem diminuem à medida que as forrageiras amadurecem e alcançam as fases de florescimento e frutificação (Blaser et al., 1986).

Um dos parâmetros utilizados para avaliar o valor nutritivo das plantas forrageiras é a concentração de proteína bruta no tecido vegetal. Milford \& Minson (1965) citaram que há redução no consumo de matéria seca pelos animais quando o teor de proteína bruta estiver abaixo de 7\% nas gramíneas tropicais.

Fernandes et al. (1985) observaram em Brachiaria decumbens que doses de nitrogênio de 0 a $40 \mathrm{~kg} \mathrm{ha}^{-1}$ resultaram em baixas concentrações de nitrogênio na parte aérea, correspondentes a 7,8 e $9,0 \mathrm{~g} \mathrm{~kg}^{-1}$, respectivamente. Botrel et al. (1990) verificaram que o teor de proteína bruta na matéria seca de todos os acessos de Brachiaria estudados aumentou em função do nitrogênio aplicado, tanto no período da seca como no período das águas.

Carvalho et al. (1991) constataram concentrações baixas de nitrogênio na parte aérea de Brachiaria decumbens, com valores de 1,7 a 2,1\%. Na ausência do nitrogênio, as concentrações desse nutriente variaram de 0,8 a $1,4 \%$. Também verificaram que nos tratamentos com elevadas produções de matéria seca, obtidas com altas doses de adubo, houve uma redução nas concentrações de nitrogênio na forragem, caracterizando um efeito de diluição. 


\subsection{Enxofre}

Vitti \& Novaes (1986) verificaram numa revisão, que o enxofre na planta encontra-se em sua maior parte nas proteínas, como componentes dos aminoácidos cistina e cisteína, desempenhando funções vitais no metabolismo proteíco e nas reações enzimáticas, sendo também componente da molécula de acetil-CoA influenciando o metabolismo energético de gorduras e carboidratos. É ainda componente da ferrodoxina, molécula transferidora de elétrons envolvida na fotossíntese, na fixação de $\mathrm{N}_{2}$ atmosférico e na redução de oxidados como o nitrato. A deficiência de enxofre reduz a quantidade de nitrogênio, restringindo o crescimento da planta. A estrutura da membrana celular e suas funções também necessitam de enxofre, pois os sulfolipídeos, que são essenciais para a composição da mesma, estão intimamente envolvidos na organização de clorofila na lamela de cloroplasto. O enxofre também faz parte de compostos que transmitem sabores e odores, os quais são importantes na aceitabilidade da pastagem pelos animais. Assim, o fornecimento adequado de enxofre para as plantas forrageiras deverá, entre outros objetivos, além de visar a maximização da produção, também aumentar o conteúdo de aminoácidos sulfurados na dieta animal.

Segundo Malavolta (1980), o enxofre é absorvido pelas raízes na forma ativa e, preferencialmente na forma oxidada de sulfato $\left(\mathrm{SO}_{4}^{-2}\right)$ e na forma orgânica como aminoácidos ( cisteína, cistina e metionina). O sulfato é transportado predominantemente na direção acrópeta. Contudo, a capacidade da planta para deslocar o enxofre na direção basípeta é reduzida.

Marschner (1995) afirmou que a cisteína é o primeiro produto estável da redução do sulfato assimilado e atua como percursora para a síntese de todos os outros compostos contendo enxofre reduzido, como também para formação de produtos biosintéticos, como o etileno. Altas concentrações de cisteína podem inibir a ação da enzima adenosina 5 -fosfosulfato (APS) sulfotransferase que atua no processo de redução do sulfato. 
Considerando que os solos brasileiros de cerrados são, via de regra, pobres em matéria orgânica, de constituição física arenosa, sujeitos a uma estação chuvosa definida, e o que é mais agravante, sujeito a queimadas periódicas como instrumento de manejo das pastagens, é de se prever que os teores de enxofre e nitrogênio situem-se aquém das necessidades do animal (Haddad, 1983).

Nos últimos anos, a elevada utilização de adubos concentrados como a uréia, fosfatos de amônio e cloreto de potássio, reduziu significativamente a adição do enxofre nas áreas de cultivo, com efeitos mais agravantes em solos de textura mais arenosa, submetidos a queimadas periódicas, com baixos teores de matéria orgânica e alta incidência pluviométrica, favorecendo a lixiviação do sulfato (Vitti \& Novais, 1986).

Em estudos desenvolvidos pelo CIAT (1978) constatou-se que, entre as gramíneas avaliadas quanto a influência do enxofre, a Brachiaria decumbens foi a mais exigente, respondendo a aplicações de até $20 \mathrm{~kg} \mathrm{ha}^{-1}$.

Casagrande \& Souza (1982), em trabalhos para avaliar a resposta de gramíneas forrageiras a quatro doses de enxofre $\left(0,15,30,60 \mathrm{~kg} \mathrm{ha}^{-1}\right)$ em três solos (Areia Quartzosa, Latossolo Vermelho Escuro eutrófico fase cerradão, Latossolo Vermelho Escuro distrófico fase cerrado), após três cortes, observaram que as plantas forrageiras responderam significativamente até 30 $\mathrm{kg} \mathrm{ha}^{-1}$, sendo a Brachiaria decumbens e Melinis minutiflora cv. Cabelo-deNegro as espécies que mais responderam em aumento da produção de matéria seca.

Werner \& Monteiro (1988) mencionaram que, as maiores respostas de plantas forrageiras à adubação com enxofre têm ocorrido em solos arenosos com baixos teores de matéria orgânica, e que pastagens exclusivas de gramíneas não adubadas com nitrogênio e fósforo mostram pouca ou nenhuma resposta ao enxofre. Esses autores citaram ainda que, a concentração desse nutriente na planta acima daquela requerida para a síntese de proteínas resulta 
em acumulação do enxofre no tecido vegetal, especialmente na forma de sulfato.

Avaliando a produção de matéria seca, proteína bruta, percentagem de folhas e colmos e composição mineral dos capins Brachiaria decumbens cv. Basilisk e Brachiaria brizantha cv. Marandu em Latossolo Vermelho-Escuro, Ferrari Júnior et al. (1994) obtiveram valores médios de enxofre de 0,12\%,para a Brachiaria decumbens e Brachiaria brizantha, e notaram, também, que os teores de enxofre não diferiram entre as gramíneas.

Em estudos com Brachiaria decumbens, Faquin et al. (1995) observaram que as máximas produções de matéria seca no primeiro e no segundo cortes, foram obtidas nas doses de enxofre de 65 e $100 \mathrm{mg} \mathrm{kg}^{-1}$ de solo, respectivamente. Os autores observaram que os maiores incrementos na produção ocorreram nas doses mais baixas de enxofre.

\subsubsection{Relação nitrogênio: enxofre}

Segundo Santos (1997) a importância do equilíbrio entre a quantidade de nitrogênio e enxofre no solo e na planta é refletida no crescimento e no estado nutricional do vegetal. A adição de doses mais elevadas de um desses elementos no sistema de produção pode induzir à menor disponibilidade de um outro elemento para a planta. $O$ mesmo autor enfatiza que o nitrogênio e $O$ enxofre são componentes da molécula dos aminoácidos. Em condições de deficiência desses elementos, pode ocorrer menor teor de aminoácidos, diminuição na síntese de proteínas e aumentos na relação $\mathrm{N}$ solúvel: $\mathrm{N}$ proteíco.

As necessidades de enxofre em plantas forrageiras tropicais têm sido comumente avaliadas pela análise de tecidos vegetais. Determinações de enxofre total e relação N/S de toda a parte aérea, como de partes definidas, têm sido usadas para essas finalidades (Vitti \& Novaes, 1986). 
Um dos índices mais comuns para avaliar o estado nutricional da planta, quanto ao enxofre, bem como para avaliar a produção máxima de forragens e adequada produção animal, é a relação N/S do tecido da planta.

Monteiro \& Carriel (1987), em trabalhos realizados com dois solos arenosos do Estado de São Paulo, aplicaram doses de enxofre de 0 a $120 \mathrm{~kg}$ $\mathrm{ha}^{-1}$ (na forma de gesso) em experimento com o capim colonião. Observaram acréscimos significativos na produção de matéria seca dessa gramínea, sendo a máxima produção, no caso do solo Areia Quartzosa, com a dose de enxofre de $75 \mathrm{~kg} \mathrm{ha}^{-1}$. Acrescentaram ser necessária a aplicação de enxofre entre $30 \mathrm{e}$ $40 \mathrm{~kg} \mathrm{ha}^{-1}$ para que esse capim apresentasse um teor de enxofre entre $0,08 \% \mathrm{e}$ $0,11 \%$ e uma relação de $\mathrm{N}: \mathrm{S}$ de $13,7: 1$ quando cultivado em qualquer daqueles solos.

Haddad (1983) realizou estudos com aplicação de doses de enxofre sob a forma de gesso, associadas com doses de nitrogênio, a um solo de cerrado, para cultivo de capim colonião e observou que houve respostas acentuadas do capim à aplicação de enxofre somente quando o nitrogênio foi também empregado na adubação.

Num estudo para avaliar respostas da Brachiaria decumbens Stapf cv. Basilisk a doses de nitrogênio e enxofre quanto à produção de matéria seca, número de perfilhos e acúmulo desses nutrientes nos componentes da planta, Santos (1997) verificou que o aumento das doses de enxofre proporcionou aumentos na produção de matéria seca da parte aérea e das raízes da braquiária. O número de perfilhos não sofreu influência das doses de enxofre no primeiro crescimento, mas foi incrementado no segundo crescimento para as doses de 64 e $80 \mathrm{mg}$ de enxofre $\mathrm{L}^{-1}$ de solução nutritiva. Apesar dessas doses não diferirem entre si, apresentaram um número de perfilhos superior às doses mais baixas de enxofre.

Mattos (2001) avaliando doses de nitrogênio e enxofre, na Brachiaria decumbens cultivada em cilindros contendo terra de área recentemente adubada e área não recentemente adubada, também verificou efeitos desses 
nutrientes na produção de matéria seca, perfilhamento, área foliar e valor SPAD.

\subsection{Perfilhamento}

Os perfilhos têm origem nas gemas que estão presentes na axila das folhas, e possuem estrutura similar ao do perfilho mãe. As folhas dos perfilhos também possuem gemas axilares, que podem dar origem a novos perfilhos e assim sucessivamente. Os perfilhos da haste principal são denominados primários e os surgidos posteriormente secundários e terciários em função da hierarquia de aparecimento (Langer, 1963). O mesmo autor citou que a capacidade de perfilhamento das gramíneas forrageiras depende de muitos fatores, dentre os quais as características genéticas de cada espécie, a intensidade luminosa, o suprimento de água, florescimento, fotoperíodo, reguladores de crescimento, regime de corte e seu estado nutricional.

O nitrogênio é fundamental no crescimento de gramíneas, tendo influência sobre tamanho das folhas, do colmo e do desenvolvimento dos perfilhos (Werner, 1986). Corsi (1986) enfatizou que no momento da aplicação da adubação nitrogenada, a luminosidade e a disponibilidade de água são fatores que influenciam no efeito do nitrogênio sobre o perfilhamento da planta. Esse nutriente deve estar disponível no período em que a planta estimula todos os sítios de crescimento para a reconstituição da parte aérea.

Nabinger (1997) relatou efeitos positivos do nitrogênio sobre a taxa de aparecimento de perfilhos. Contudo, altas disponibilidades desse elemento podem determinar uma menor densidade populacional de perfilhos na pastagem devido ao mais rápido desenvolvimento do índice de área foliar e ao aumento na mortalidade.

Wilman \& Pearse (1984) trabalhando com pastagens de azevém (Lolium perene), observaram um aumento tanto no número de novos "sítios de 
perfilhamento" como no número de novos perfilhos emergindo em função do incremento nas doses de nitrogênio de 0 para 66 e para $132 \mathrm{~kg} \mathrm{ha}^{-1}$.

Hoffmann (1992) avaliou o efeito de doses de nitrogênio até a dose de $500 \mathrm{mg} \mathrm{kg}^{-1}$ de solo em Brachiaria decumbens, e observou que o perfilhamento, por ocasião do primeiro corte, seguiu a mesma tendência de resposta da produção de matéria seca (quadrática). Nesse estudo, a braquiária apresentou maiores taxas de perfilhamento e produção de matéria seca em relação ao colonião.

Avaliando o efeito da aplicação de nitrogênio sobre o crescimento do capim-braquiária e capim-colonião, Hoffmann et al. (1995) utilizaram as seguintes doses $0 ; 100 ; 200$ e $500 \mathrm{mg} \mathrm{kg}^{-1}$ de solo, sendo cada dose subdividida em $1 / 3$ na semeadura, $1 / 3$ aos 15 dias e 1/3 aos 30 dias após a emergência. Constataram que no primeiro corte o máximo perfilhamento de 13,9 e 3,8 perfilhos/planta para a braquiária e o colonião, ocorreu nas doses de nitrogênio 376 e $410 \mathrm{mg} \mathrm{kg}^{-1}$ de solo, respectivamente. Já os máximos valores de produção de matéria seca da parte aérea foram encontrados nas doses de nitrogênio de 342 e $338 \mathrm{mg} \mathrm{kg}^{-1}$ de solo. Para os capins braquiária e colonião, as doses de nitrogênio no solo para os máximos de perfilhamento foram mais elevadas que as necessárias para maximizar a produção de matéria seca da parte aérea.

Em estudo com Brachiaria brizantha, Monteiro et al. (1995) constataram reduções significativas no número de perfilhos no tratamento em que se omitiu o enxofre, quando comparado ao tratamento completo. Faquin et al. (1995) trabalhando em vasos com Latossolo Vermelho-Escuro, observaram respostas significativas às aplicações de enxofre para o perfilhamento da Brachiaria decumbens, sendo a dose de $98 \mathrm{mg} \mathrm{kg}^{-1}$ de solo, a que proporcionou o número máximo de perfilhos. Entretanto, para o capim colonião não foi constatada influência desse nutriente sobre o perfilhamento.

\section{6 Área foliar}


A determinação da área foliar constitui-se numa importante ferramenta nos estudos de nutrição e adubação nitrogenada em plantas forrageiras, podendo a resposta da planta em produção ser avaliada através dessa variável resposta. A área da lâmina foliar pode ser medida através de equipamento integrador de área foliar que permite leitura diretamente nas plantas (modelos portáteis) ou em folhas destacadas (Premazzi, 2001).

Segundo Taiz \& Zaiger (1991), o crescimento de um vegetal inicia-se com a germinação da semente, emergência da plântula e formação das primeiras folhas sobre o perfilho principal. A continuação do processo de formação de folhas e aparecimento de perfilhos primários e secundários caracterizam a fase linear de crescimento, de rápidos aumentos de peso, altura e área foliar. A última fase da curva sigmóide, que descreve o crescimento da planta, é alcançada quando a formação de novos tecidos é compensada pela senescência e morte de partes mais velhas .

Para Humphries \& Wheeler (1963), o tamanho final de uma folha é determinado pelo número de células primordiais, taxa de divisão celular, duração da fase de divisão celular e tamanho das células maduras, e isso varia conforme a planta e o seu estado nutricional.

Dentre os fatores limitantes ao índice de área foliar (IAF), a deficiência de nitrogênio e de água são considerados de maior importância. Tanto a deficiência de nitrogênio como de água diminuem progressivamente a taxa fotossintética das folhas, a interceptação da luz, a produção de biomassa e o índice de área foliar do pasto (Nabinger, 1997).

O crescimento da folha é um dos parâmetros a ser avaliado quanto ao efeito do nitrogênio em pastagens. O suprimento de nitrogênio influencia a produção da forragem principalmente através do seu efeito sobre o tamanho da folha, que ocorre tanto nas plantas individualmente como em nível de dossel (Whitehead, 1995). Esse elemento faz parte das proteínas, moléculas essenciais para o metabolismo dos seres vivos. Mas essas moléculas contêm em média $16 \%$ de nitrogênio, e por isso, a ação do nitrogênio só poderá resultar 
em aumento de biomassa agindo sobre a fixação do carbono. Essa ação se manifesta, de um lado, melhorando diretamente a eficiência da fotossíntese e, por outro lado, promovendo a redistribuição prioritária do carbono para a formação da parte aérea, que resulta em maior área fotossintetizante. Esse efeito é mais importante em relação ao primeiro e resulta do aumento da taxa de elongação de folhas por área e, em menor proporção, do ritmo de surgimento de folhas por área, menor senescência e maior número de perfilhos por área (Gastal \& Lemaire, 1988).

O efeito do nitrogênio sobre a taxa de elongação foliar, decorre do maior acúmulo desse nutriente na zona de alongamento da folha, mais precisamente na região de divisão celular (Gastal \& Nelson, 1994). Os autores verificaram ainda alta correlação entre a quantidade de nitrogênio contido nessa região e a taxa de elongação foliar. Segundo Mazzanti \& Lemaire (1994), a deficiência de nitrogênio reduz ligeiramente a duração de vida das folhas, sendo que a taxa de senescência aumenta devido ao efeito do nitrogênio na taxa de aparecimento e no tamanho da folha.

Pearse \& Wilman ( 1984) constataram que a taxa de expansão foliar de azevém aumentou de 4,2 para 8,3 e 12,1 mm perfilho-1 dia quando utilizou-se doses de nitrogênio de 0; 66 e $132 \mathrm{~kg} \mathrm{ha}^{-1}$, respectivamente. Gastal et al. (1992) também ressaltaram que, a disponibilidade de nitrogênio tem pronunciado efeito sobre a taxa de alongamento das folhas por perfilho, podendo resultar em valores de três a quatro vezes menores num alto nível de deficiência, relativamente a um nível não limitante desse nutriente. Outros estudos (Pinto et al., 1994; Premazzi 2001; Mattos 2001 e Lavres Júnior 2001) também mostram os efeitos significativos do nitrogênio sobre a área foliar de gramíneas forrageiras. 


\subsection{Estimativa do teor de clorofila em valor SPAD}

Desenvolvido pela Companhia Minolta no Japão, o aparelho portátil Chlorophyll Meter SPAD-502 (Soil and Plant Analysis Development) permite a avaliação indireta do teor de clorofila nas plantas. Esse aparelho recebeu no Brasil o nome de clorofilômetro, e expressa os resultados em valor de unidades SPAD. Por ser portátil e de fácil manuseio, esse aparelho é usado diretamente no campo, e fornece resultados imediatos da estimativa do teor de clorofila através de leituras realizadas no limbo foliar (Minolta Camera Corporation, 1989).

O medidor de clorofila SPAD-502 fornece leituras que correspondem ao teor do pigmento presente na folha. Os valores são calculados com base na quantidade de luz transmitida pela folha em duas regiões de comprimento de onda nas quais a absorção pela clorofila é diferente. $O$ instrumento tem sido usado para estimar a concentração de nitrogênio da folha, visto que o teor de clorofila se relaciona positivamente com a concentração desse nutriente (Malavolta et al., 1997).

Fox et al. (1994) buscaram determinar a necessidade de adubação nitrogenada complementar através de avaliação da correlação entre a concentração de nitrogênio em folhas do trigo de inverno (Triticium aestivum) e a estimativa do teor de clorofila utilizando o aparelho SPAD-502. Constataram que o valor crítico foi de 46 unidades SPAD e que os resultados do uso do clorofilômetro foram corretos para predizer as doses de fertilizantes nitrogenados necessárias para obtenção da máxima colheita econômica.

O SPAD-502 tem sido utilizado com sucesso para diagnosticar a concentração de nitrogênio em culturas como milho (Piekielek \& Fox, 1992; Blackmer et al., 1994), batata (Minotti et al., 1994), trigo (Hoel \& Solhaug, 1998), tomate (Guimarães et al., 1999), maçã (Neilsen et al., 1995), entre outras.

Turner \& Jund (1991), em experimento com três tipos de solos no Texas-EUA, verificaram a necessidade de adubação nitrogenada complementar 
para a cultura do arroz por meio de leituras SPAD, e encontraram que o valor crítico correspondeu a 42 unidades SPAD.

Com relação às plantas forrageiras, Kantety et al. (1996) avaliaram diversos genótipos de festuca submetidos a doses de nitrogênio. No primeiro experimento, utilizando doses de nitrogênio de 0 a $392 \mathrm{~kg} \mathrm{ha}^{-1}$, observaram uma relação quadrática entre leitura SPAD-502 e nitrogênio aplicado, sendo um máximo de resposta da leitura do SPAD obtido com nitrogênio de $254 \mathrm{mg}$ $\mathrm{ha}^{-1}$. Os valores das leituras SPAD e os coeficientes de determinação diminuíram no decorrer do período de crescimento das plantas, sugerindo que a concentração de clorofila diminuiu e a variação aumentou à medida que as plantas se tornaram mais velhas. No segundo experimento, realizado em condições de campo, as doses de nitrogênio utilizadas variaram de 0 a $336 \mathrm{~kg}$ $\mathrm{ha}^{-1}$ e as leituras SPAD apresentaram uma relação quadrática com as doses de nitrogênio. Os valores de coeficientes de determinação variaram entre 0,97; 0,96 e 0,99 em função do local amostrado, sendo que a máxima resposta do valor SPAD ocorreu na dose de nitrogênio de $306 \mathrm{~kg} \mathrm{ha}^{-1}$.

Avaliando os efeitos de doses de nitrogênio e fósforo sobre a leitura SPAD nas folhas de quatro cultivares de Panicum maximum (Aruana, Tanzânia, Tobiatã e Vencedor), Paulino et al. (1998) concluíram que essa leitura pode identificar prontamente severas deficiências de nitrogênio em Panicum maximum em condições de campo, e que os teores de clorofila correspondentes a menos de 38 unidades de SPAD são indicativos de estado nutricional inadequado.

Santos (1997) avaliando em casa-de-vegetação os efeitos de nitrogênio e de enxofre sobre o teor estimado de clorofila em Brachiaria decumbens cv. Basilisk, observou que o teor de clorofila na planta forrageira variou entre 17,0 no primeiro crescimento, e 23,9 unidades, no segundo crescimento, para a condição de omissão de nitrogênio e de 50,2 e 52,0 unidades para as doses de nitrogênio de 330 e $442 \mathrm{mg} \mathrm{L}^{-1}$, respectivamente. Para o estudo com enxofre, 
o valor SPAD máximo esteve em 43,1 unidades no primeiro crescimento e em 38,0 unidades de valor SPAD no segundo crescimento.

Colozza (1998), estudando o capim-Mombaça cultivado em Latossolo Vermelho-Amarelo em condições de casa-de-vegetação, obteve valores de nitrogênio entre 32,0 e 38,6 unidades SPAD. Manarin (2000), ao cultivar o mesmo capim em doses de nitrogênio, obteve valores entre 41 e 45 unidades SPAD. Mattos (2001) também constatou efeitos significativos da interação entre as doses de nitrogênio e enxofre no valor SPAD do capim-braquiária em áreas recentemente adubadas e não recentemente adubadas. 


\section{MATERIAL E MÉTODOS}

\subsection{Localização e espécie forrageira}

O experimento foi conduzido em casa-de-vegetação no Departamento de Ciências Biológicas, da Escola Superior de Agricultura "Luiz de Queiroz"USP, em Piracicaba, no Estado de São Paulo. A espécie forrageira utilizada foi a Brachiaria decumbens Stapf., que foi cultivada no período de janeiro a março de 2001.

\subsection{Doses de calcário, nitrogênio e enxofre e delineamento experimental}

Foi utilizado um esquema fatorial $4 \times 4 \times 3$, envolvendo quatro doses de calcário ( $0 ; 1587,6 ; 3175,2$ e 4762,8 mg kg-1 de solo), quatro doses de nitrogênio $\left(0 ; 180 ; 630\right.$ e $1080 \mathrm{mg} \mathrm{kg}^{-1}$ de solo) e três doses de enxofre $(0 ; 108 \mathrm{e}$ $216 \mathrm{mg} \mathrm{kg}^{-1}$ de solo), perfazendo um total de 48 combinações, as quais foram distribuídas segundo um delineamento experimental de blocos completos ao acaso, com três repetições.

\subsection{Instalação e condução do experimento}

O solo utilizado no experimento, foi coletado na estação experimental do Instituto de Zootecnia de Brotas-SP, numa pastagem que apresentava sinais visíveis de degradação nutricional, com mais de quinze anos de uso e que nunca havia sido adubada. O solo da região é classificado como Neossolo 
Quartzarênico (EMBRAPA, 1999), possuindo as seguintes características químicas: $14 \mathrm{~g} / \mathrm{dm}^{3}$ de MO, $2 \mathrm{mg} / \mathrm{dm}^{3}$ de $\mathrm{P}, 1,2 \mathrm{mmol} / \mathrm{dm}^{3}$ de $\mathrm{K}, 7$ de $\mathrm{Ca}, 4$ de $\mathrm{Mg}, 26$ de $\mathrm{H}+\mathrm{Al}$ e 4,9 de $\mathrm{pH}$ em $\mathrm{CaCl}_{2} ; 12,6$ de S; 38,9 de T; $32 \%$ de V e 0,19 de $\mathrm{mg} / \mathrm{dm}^{3}$ de B, 0,4 de Cu, 59,6 de Fe, 3,0 de Mn e 1,2 de Zn.

O solo utilizado no experimento foi coletado a uma profundidade de $0-20$ $\mathrm{cm}$, e depois seco, homogeneizado, peneirado, pesado, colocado em sacos plásticos, aplicando-se o calcário, para então ser depositado em vasos com capacidade para $10 \mathrm{~kg}$. Todos os vasos receberam água desmineralizada até a capacidade máxima de retenção afim de permitir reação do calcário com o solo.

As sementes utilizadas receberam um tratamento para quebra de dormência, que resultou em aumento de germinação de $41 \%$, para $73 \%$ e pureza física $38,6 \%$.

A semeadura foi realizada 60 dias após a aplicação do calcário, utilizando-se 30 sementes por vaso. Em seguida foi aplicada a quantidade de fósforo equivalente a $288 \mathrm{mg} \mathrm{kg}^{-1}$ de solo na forma de $\mathrm{KH}_{2} \mathrm{PO}_{4}$ para fornecer fósforo e potássio, micronutrientes $(72 \mathrm{mg} / \mathrm{vaso}$ de cloreto de zinco e a mesma quantidade de cloreto de cobre) e as doses de enxofre $\left(0,108\right.$ e $216 \mathrm{mg} \mathrm{kg}^{-1}$ de solo). Após 7 dias da germinação foi efetuado o primeiro desbaste, seguido de desbastes periódicos até ficarem 4 plantas por vaso. Aos 13 dias após a semeadura foram aplicadas as doses de nitrogênio ( 0, 180, 630 e $1080 \mathrm{mg} \mathrm{kg}^{-1}$ de solo).

Aos 30 dias após a adubação realizou-se o primeiro corte, a uma altura de cinco centímetros do colo das plantas e coletou-se a parte aérea que foi separada em: a) folhas emergentes (FE) : folhas do topo da planta, sem lígula visível; b) lâminas de folhas recém-expandidas (LN): lâminas das duas folhas mais novas completamente expandidas, com lígula visível; c) lâminas de folhas maduras (LM): lâminas das demais folhas completamente expandidas, com lígula visível; d) colmos mais bainhas (CB): colmos mais as bainhas que foram mantidas a eles circundadas. A separação dos quatro componentes da parte 
aérea das plantas se deu de forma idêntica a adotada por Mattos (1997), Santos(1997), Ferragine (1998) e Benetti \& Monteiro (1999) com diferenças somente nas denominações desses componentes (já que as expressões de folhas não-expandidas, folhas novas, folhas velhas e colmos mais bainhas foram adotadas naqueles estudos). Foi realizado ainda, uma coleta de solo para análise e uma adubação de reposição de potássio, calculada com base numa extração equivalente de $2 \%$ desse elemento na produção de matéria seca.

Aos 21 dias após o primeiro corte realizou-se a segunda colheita, separando-se a parte aérea pelo mesmo critério adotado no primeiro corte. Ao final desse último corte foi realizada coleta do solo para análise e separação das raízes, que foi realizada com auxílio de jatos de água pressurizados, ficando o bloco de solo apoiado em cima de peneiras com aberturas de $5 \mathrm{~mm}$.

Todo o material foi colocado para secar em estufa de circulação forçada de ar à temperatura de $65{ }^{\circ} \mathrm{C}$, por 72 horas. As amostras foram moídas em moinho tipo Wiley com peneira de 2 mesh e acondicionados em sacos plásticos para serem enviados ao laboratório para determinação de nitrogênio, potássio, cálcio, magnésio, enxofre e os micronutrientes (boro, cobre, ferro, manganês e zinco).

\subsection{Determinação do número de perfilhos, teor de clorofila e avaliação da área foliar}

Durante o período de crescimento da espécie forrageira foram marcados a cada cinco dias os perfilhos emitidos. No primeiro período de crescimento as marcações foram iniciadas a partir do $12{ }^{0}$ dia após a semeadura e, no segundo crescimento, um dia após o $1^{0}$ corte e de cinco em cinco dias a partir dessa data.

O Chlorophyll Meter SPAD-502, (Soil-Plant Analysis Development Section, Minolta Camera Co., Osaka, Japan) foi utilizado para as medidas indiretas de clorofila em valor SPAD, em folhas intactas. Os espectros de 
absorção são determinados com base na quantidade de luz transmitida pela folha amostrada em dois comprimentos de onda, sendo nas áreas do vermelho aproximadamente em $650 \mathrm{~nm}$ e infravermelho em $940 \mathrm{~nm}$, onde os picos de absorção são máximo e mínimo, respectivamente. Nessa faixa, as leituras não são influenciadas pela presença de outros pigmentos. A luz transmitida é convertida em sinais elétricos, que são digitalizados e microprocessados para cálculo em valor SPAD da medida de clorofila (Minolta Câmera, 1989). As leituras do clorofilômetro foram realizadas antes do primeiro e segundo cortes da planta forrageira, no terço médio da lâmina da segunda folha completamente expandida a partir do ápice de cada planta, conforme Santos (1997).

Por ocasião dos cortes, as folhas emergentes e as lâminas foliares (LN e LM) foram, separadamente, acondicionas em sacos plásticos e foram colocadas em câmara fria. Em seguida tiveram sua área determinada em aparelho integrador de área foliar, marca LI-COR, modelo LI 3100. Após essa avaliação as lâminas foliares foram postas para secar em estufa. Após a realização dessa medida o material vegetal foi acondicionado em sacos de papel identificados e foi levado para estufa secadora.

\subsection{Produção de matéria seca}

Para a obtenção dos resultados de produção de massa seca da parte aérea somaram-se os pesos dos seus componentes (folhas emergentes, lâminas de folhas recém-expandidas, lâminas de folhas maduras e colmos mais bainhas), enquanto o das raízes foi obtido diretamente pela pesagem do material. 


\subsection{Análises químicas}

As determinações químicas dos nutrientes nos tecidos vegetais colhidos nos cortes da forrageira foram realizadas no Laboratório de Nutrição Mineral de Plantas da Escola Superior de Agricultura "Luiz de Queiroz", segundo a metodologia descrita por Sarruge \& Haag (1974). A digestão sulfúrica foi utilizada para obtenção do extrato, e a determinação do nitrogênio total envolveu a destilação em aparelho semi-micro Kjeldahl e titulação com ácido sulfúrico. A determinação de $\mathrm{Ca}, \mathrm{Mg}, \mathrm{K}, \mathrm{P}, \mathrm{S}, \mathrm{Zn}, \mathrm{Cu}, \mathrm{Fe}$ e $\mathrm{Mn}$ foi feita a partir de um extrato obtido por digestão nítrico-perclórica. O fósforo foi determinado colorimetricamente; o potássio por fotometria de chama; $\mathrm{Ca}, \mathrm{Mg}$, $\mathrm{S}, \mathrm{Zn}, \mathrm{Cu}, \mathrm{Fe}$ e Mn por espectrofotometria de absorção atômica.

\subsection{Análises estatísticas}

Os resultados foram analisados estatisticamente através da análise de variância e, nos casos de significância $(P<0,05)$, procedeu-se o estudo das regressões para os componentes de primeiro e de segundo grau; e teste de médias (Tukey $5 \%$ ) somente para o perfilhamento. Empregou-se o procedimento estatístico "Statistical Analysis System" (SAS Institute, 1996). 


\section{RESULTADOS E DISCUSSÃO}

\subsection{Produção de matéria seca da parte aérea}

A análise de variância da produção de matéria seca da parte aérea revelou significância $(P<0,05)$ para as doses de nitrogênio e interação nitrogênio e enxofre no primeiro e segundo cortes. As doses de nitrogênio foram representadas por uma equação de segundo grau nas duas avaliações.

Derivando-se essas equações observou-se que os valores de máxima produção de matéria seca da parte aérea foram obtidas nas doses de nitrogênio de 752 e $1113 \mathrm{mg} \mathrm{kg}^{-1}$ de solo, no primeiro e segundo cortes, respectivamente (Figura 1). No segundo corte, o ponto de máxima seria alcançado mediante dose superior à dose máxima utilizada nesse estudo. Esses valores foram mais elevados que aqueles obtidos por Hoffmann (1992) que obteve a máxima produção com a dose de nitrogênio de $437 \mathrm{mg} \mathrm{kg}^{-1}$ de solo. Santos (1997) encontrou que a máxima produção de matéria seca da parte aérea desse capim foi encontrado nas doses 435 e $433 \mathrm{mg} \mathrm{L}^{-1}$ de nitrogênio, no primeiro e segundo cortes, respectivamente.

A literatura apresenta uma vasta gama de trabalhos que mostram a importância do nitrogênio na produção da braquiária, como os resultados encontrados por Vicente-Chandler et al. (1972) com Brachiaria ruziziensis em Porto Rico e por Carvalho et al. (1990) que, obtiveram respostas significativas em produção de matéria seca até a dose de $400 \mathrm{~kg} \mathrm{ha}^{-1}$ para Brachiaria decumbens. Também foram observadas altas respostas da braquiária ao nitrogênio no trabalho de Harding \& Grof (1978), que estudaram doses de nitrogênio em Brachiaria decumbens e constataram como ótima a dose de 365 
$\mathrm{kg} \mathrm{ha}^{-1} \mathrm{ano}^{-1}$, em termos de produção de matéria seca e aproveitamento do nutriente.

Ferragine (1998) constatou que as doses de nitrogênio apresentaram respostas lineares e foram significativas apenas no segundo crescimento da braquiária. Mattos (2001) encontrou que a produção de matéria seca da parte aérea da Brachiaria decumbens foi influenciada pelas doses de nitrogênio apenas no terceiro corte e o ponto de máxima produção ocorreu com o nitrogênio aplicado na adubação em $141 \mathrm{mg} \mathrm{dm}^{-3}$.

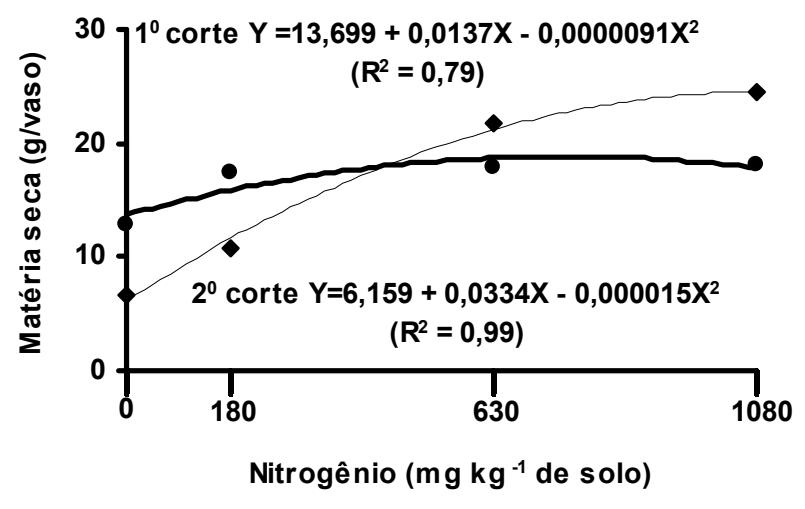

Figura 1 - Produção de matéria seca da parte aérea da Brachiaria decumbens, no primeiro e segundo crescimentos, em função das doses de nitrogênio.

No primeiro crescimento, a produção de matéria seca da parte aérea foi significativamente $(P<0,05)$ influenciada pelas doses de enxofre dentro das doses de nitrogênio 0,630 e $1080 \mathrm{mg} \mathrm{kg}^{-1}$ de solo. Esses efeitos foram representados através de equações de primeiro grau nas doses 0 e $630 \mathrm{mg} \mathrm{kg}^{-1}$ de solo e por uma equação de segundo grau na dose $1080 \mathrm{mg} \mathrm{kg}^{-1}$ de solo (Figura 2). A máxima produção de matéria seca da parte aérea ocorreu com o suprimento de enxofre em $110 \mathrm{mg} \mathrm{kg}^{-1}$ de solo dentro da dose de nitrogênio de $1080 \mathrm{mg} \mathrm{kg}^{-1}$ de solo. 

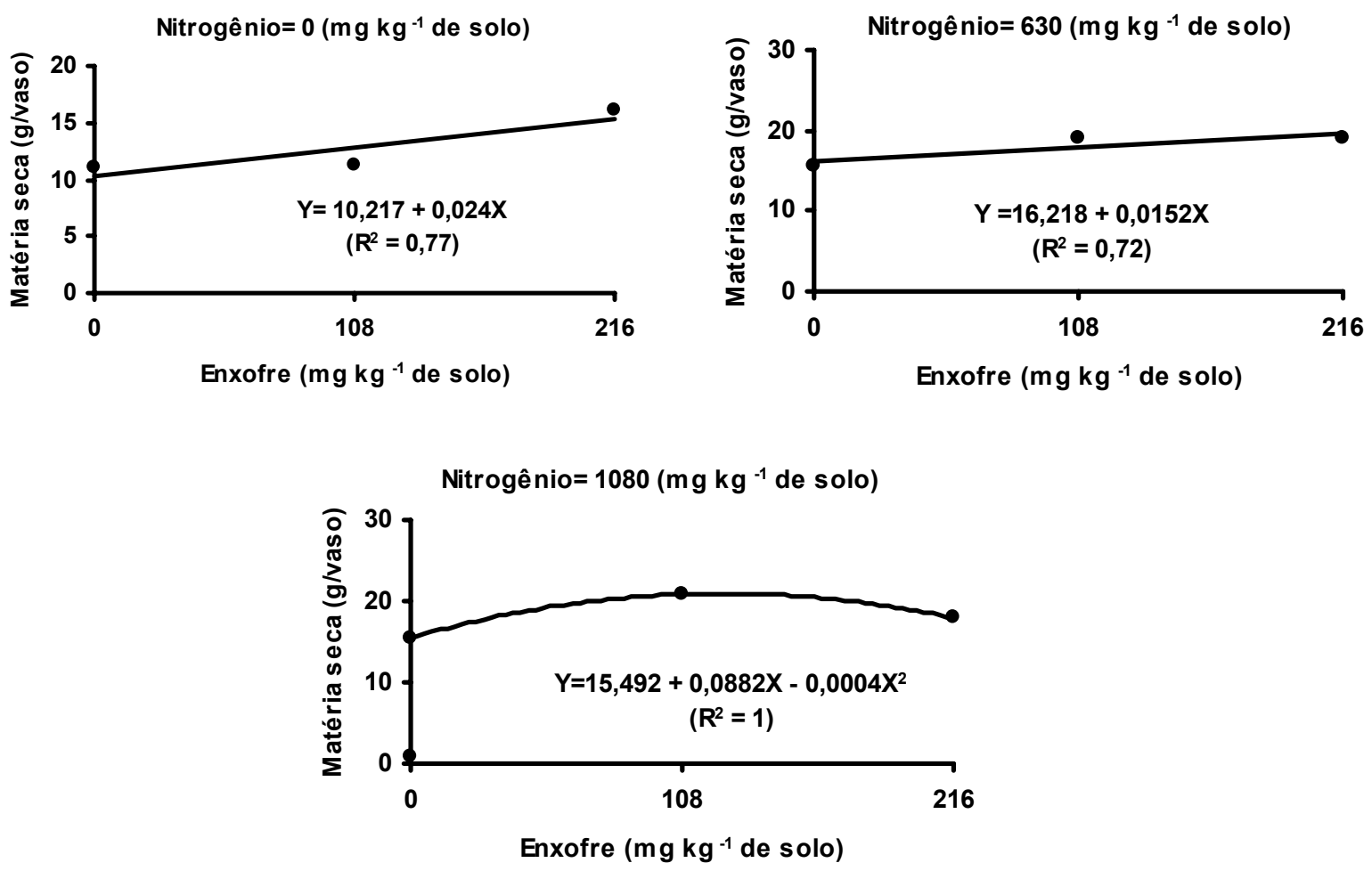

Figura 2 - Produção de matéria seca da parte aérea da Brachiaria decumbens, no primeiro crescimento, em função das doses de enxofre dentro das doses 180 e $1080 \mathrm{mg} \mathrm{kg}^{-1}$ de solo de nitrogênio.

No segundo crescimento, o estudo das doses de enxofre dentro de cada dose de nitrogênio, revelou significância $(P<0,05)$ apenas para as doses de nitrogênio 180 e $1080 \mathrm{mg} \mathrm{kg}^{-1}$ de solo. Nos dois casos o capim respondeu às doses de enxofre segundo um modelo quadrático dentro das respectivas doses de nitrogênio. No primeiro caso, a dose mínima de enxofre para que a planta produzisse foi de $95 \mathrm{mg} \mathrm{kg}^{-1}$ de solo dentro da dose de nitrogênio $180 \mathrm{mg} \mathrm{kg}^{-1}$ de solo. A maior produção de matéria seca da parte aérea no segundo crescimento ocorreu mediante o suprimento de enxofre de $138 \mathrm{mg} \mathrm{kg}^{-1}$ de solo e em presença da referida dose de nitrogênio (Figura 3). 

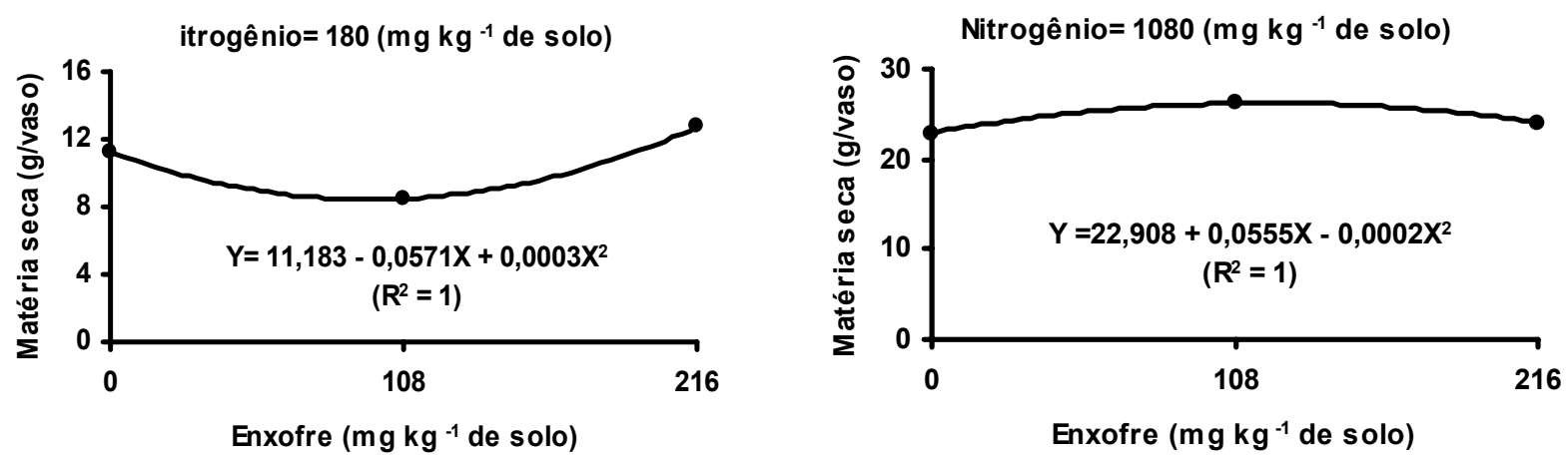

Figura 3 - Produção de matéria seca da parte aérea da Brachiaria decumbens, no segundo crescimento, em função das doses de enxofre dentro das doses 180 e $1080 \mathrm{mg} \mathrm{kg}^{-1}$ de solo de nitrogênio.

No desdobramento da interação para o estudo de nitrogênio dentro de cada dose de enxofre, em termos de produção de matéria seca da parte aérea, verificou-se efeito significativo $(P<0,05)$ do nitrogênio nas doses de enxofre 0 , $108 \mathrm{mg} \mathrm{kg}^{-1}$ de solo, no primeiro e segundo cortes (Figura 4) e para a dose 216 $\mathrm{mg} \mathrm{kg}^{-1} \mathrm{de}$ solo, no primeiro corte (Figura 5). Esses efeitos foram representados por equações de segundo grau em todos os casos. Os máximos valores de produção de matéria seca da parte aérea ocorreram nas doses de nitrogênio de 750 e 1037, primeiro e segundo cortes dentro da dose de enxofre $0 \mathrm{mg} \mathrm{kg}^{-1}$ de solo; com o suprimento de nitrogênio em 935 e1850 mg kg-1 de solo, primeiro e segundo cortes dentro da dose de enxofre $108 \mathrm{mg} \mathrm{kg}^{-1}$ de solo e na dose de nitrogênio de $937 \mathrm{mg} \mathrm{kg}^{-1}$ de solo, no primeiro corte dentro da dose de enxofre de $216 \mathrm{mg} \mathrm{kg}^{-1}$ de solo. A máxima produção de matéria seca da parte aérea na dose de enxofre $108 \mathrm{mg} \mathrm{kg}^{-1}$ de solo, no segundo corte ocorreria em doses de nitrogênio mais elevadas que as utilizadas nesse experimento. 

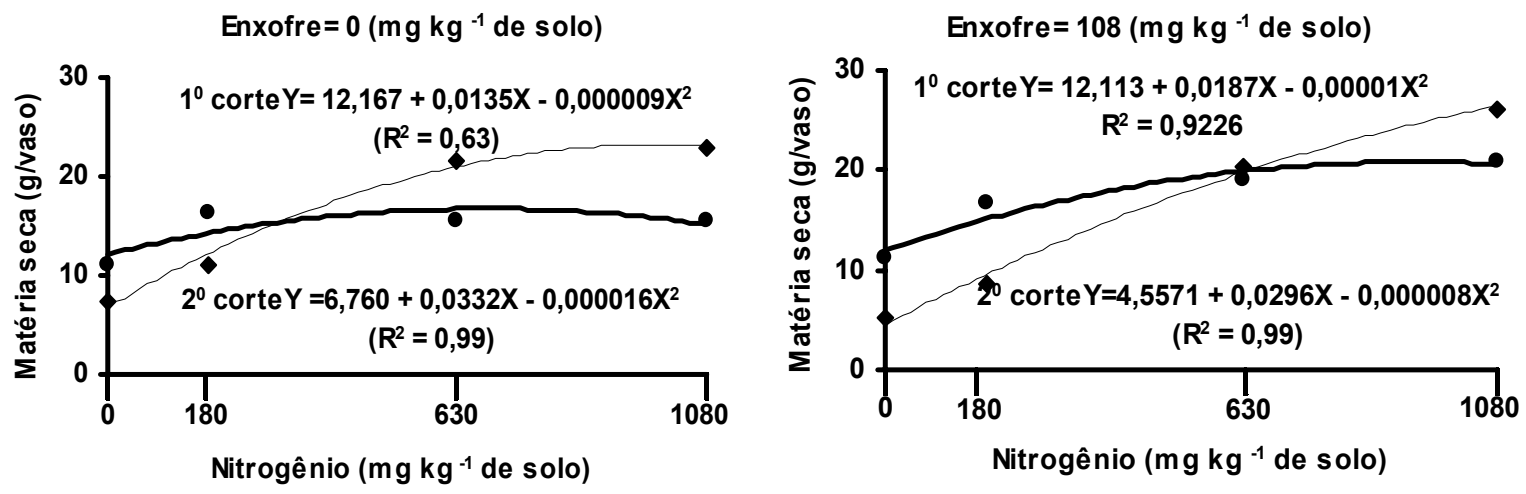

Figura 4 - Produção de matéria seca da parte aérea da Brachiaria decumbens, no primeiro e segundo crescimentos, em função das doses de nitrogênio dentro das doses de enxofre 0 e $108 \mathrm{mg} \mathrm{kg}^{-1}$ de solo.

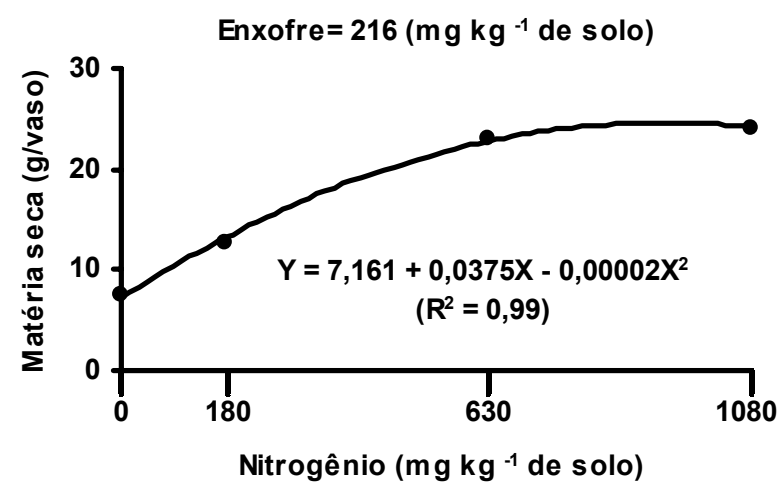

Figura 5 - Produção de matéria seca da parte aérea da Brachiaria decumbens, no primeiro crescimento, em função das doses de nitrogênio dentro da dose de enxofre de $216 \mathrm{mg} \mathrm{kg}^{-1}$ de solo.

Observou-se que a maior produção de matéria seca da parte aérea da braquiária ocorreu na interação entre as maiores doses de enxofre e nitrogênio utilizadas nesse estudo. Também foi verificado que, esses aumentos de produção ocorreram sempre no segundo corte. Essa magnitude de produção do segundo corte em relação ao primeiro, se deve ao fato de já ter ocorrido o 
estabelecimento das plantas, o que favorece uma maior absorção de nutrientes promovendo aumentos de produção de matéria seca.

Os resultados apresentados comprovam que, o nitrogênio é importante para a produção de matéria seca das plantas forrageiras, mas deve ser acompanhado de uma adubação com enxofre para proporcionar melhores rendimentos.

Esses resultados também, confirmam os descritos por Monteiro \& Carriel (1987), que apontaram ser necessário a aplicação de 30 a $40 \mathrm{~kg} \mathrm{ha}^{-1}$ de enxofre para que o capim colonião apresentasse melhor produção. Haddad (1983) observou que, houve respostas acentuadas do capim colonião à aplicação de enxofre somente quando o nitrogênio foi também empregado na adubação.

Soares Filho (1991), trabalhando com braquiária decumbens, encontrou que no tratamento com macro e micronutrientes a produção de matéria seca foi superior aos demais tratamentos e aponta como causa os efeitos da adubação de nitrogênio associada a quantidades adicionais de enxofre. Santos (1997), avaliando o mesmo capim em função de doses de nitrogênio e enxofre, verificou que o aumento das doses de enxofre proporcionou aumentos na produção de matéria seca da parte aérea. Mattos (2001), observou interação significativa $(P<0,01)$ para as doses de nitrogênio dentro de cada dose de enxofre para a produção de matéria seca do capim-braquiária. Os efeitos foram quadráticos no primeiro corte e a máxima produção foi alcançada mediante o suprimento de nitrogênio de $192 \mathrm{mg} \mathrm{dm}^{-1}$ de solo. No segundo crescimento os efeitos foram lineares.

Não foi constatado efeito significativo $(P>0,05)$ das doses de calcário sobre a produção de matéria seca em nenhuma das avaliações. Isso provavelmente, se deve ao fato de que as braquiárias apresentam boa tolerância à acidez e aos níveis de alumínio inicialmente encontrados no solo e a importância da calagem se deve mais ao fornecimento de $\mathrm{Ca}$ e $\mathrm{Mg}$ como nutrientes. 
Esse comportamento também foi verificado por Pereira (1986), que concluiu para a braquiária decumbens que, o efeito positivo do calcário foi como fonte de Ca e Mg. Martins Sobrinho (1997), avaliando tipos e doses de calcário em pastagens de capim-Tobiatã, não encontrou respostas do capim à calagem. Já Marun (1990) observou que a produção de matéria seca do capim-Colonião, brizanta e decumbens tiveram decréscimos à medida que se elevou as relações $\mathrm{Ca} / \mathrm{Mg}$ no solo, sendo esta mais acentuada na decumbens. Trabalhos relatando maior ou menor efeito da calagem no aumento da produção de matéria seca de braquiárias foram encontrados por (Siqueira et al.,1980; Pereira, 1987; Sanzonowicz et al., 1987; Premazzi, 1991; Mitidieri, 1995;).

\subsection{Produção de matéria seca das raízes}

$\mathrm{Na}$ produção de matéria seca das raízes verificou-se que não foi significativa a interação entre doses de calcário, nitrogênio e enxofre, tendo revelado efeito significativo $(P<0,05)$ apenas de doses de nitrogênio. No estudo dos efeitos das doses de nitrogênio, a produção de matéria seca das raízes da planta forrageira foi representada por uma equação de segundo grau (Figura 6). Através dessa equação verifica-se que a máxima produção de matéria seca ocorreu na dose de nitrogênio de $1033 \mathrm{mg} \mathrm{kg}^{-1}$ de solo.

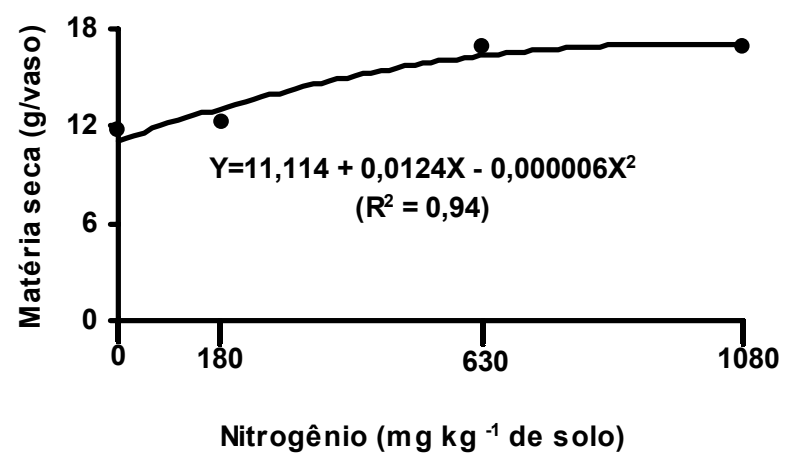

Figura 6 - Produção de matéria seca das raízes da Brachiaria decumbens, em função das doses de nitrogênio . 
Resultados semelhantes foram obtidos por Corrêa e Monteiro (1997), que trabalhando com os capins Colonião, Tanzânia-1 e Vencedor, verificaram efeitos significativos das doses de nitrogênio na produção de matéria seca das raízes. Martim (1997) também observou efeito significativo do nitrogênio para a produção de matéria seca de raízes de Tifton-85 e Coastcross-1, sendo as doses de maior produção 100 e $180 \mathrm{~kg} \mathrm{ha}^{-1}$, respectivamente. Doses estas inferiores à dose máxima utilizada nesse estudo

Santos (1997), trabalhando com a braquiária encontrou que, a máxima produção de matéria seca foi obtida na dose de $\mathrm{N}$ de $453 \mathrm{mg} \mathrm{L}^{-1}$ de solução. Premazzi (2001), avaliando doses de nitrogênio em capim-Tifton 85 constatou que a dose para obtenção da produção máxima foi de $196 \mathrm{mg} \mathrm{kg}^{-1}$ de solo.

\subsection{Perfilhamento}

$\mathrm{Na}$ análise de variância para o número total de perfilhos por vaso, no primeiro crescimento, observou-se significância $(P<0,05)$ para as doses de nitrogênio e interação entre as doses de nitrogênio e calcário, enquanto que no segundo crescimento verificou-se interação significativa $(P<0,05)$ entre doses de enxofre, nitrogênio e calcário. As doses de nitrogênio estão representadas na (Figura 7). Avaliando as doses de nitrogênio dentro de cada dose de calcário, no primeiro crescimento, foi constatado que o número de perfilhos variou com as doses de nitrogênio dentro de cada dose de calcário (Figura 8 ). 


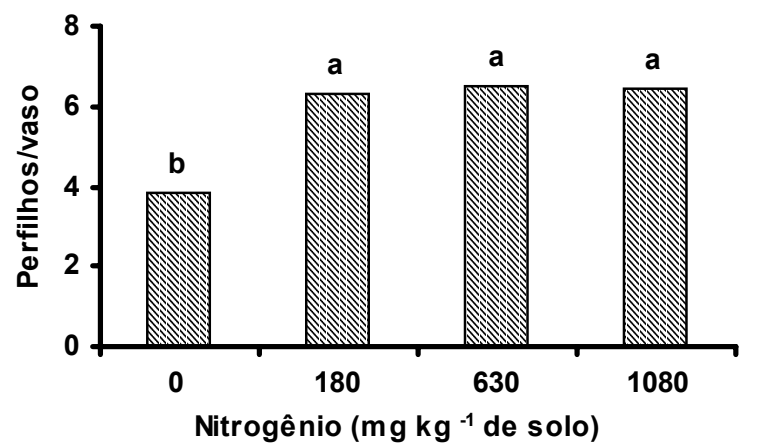

Figura 7 - Número de perfilhos/vaso na Brachiaria decumbens, no primeiro crescimento em função das doses de nitrogênio. Letras diferentes indicam significância ao nível de $5 \%$ de probabilidade.
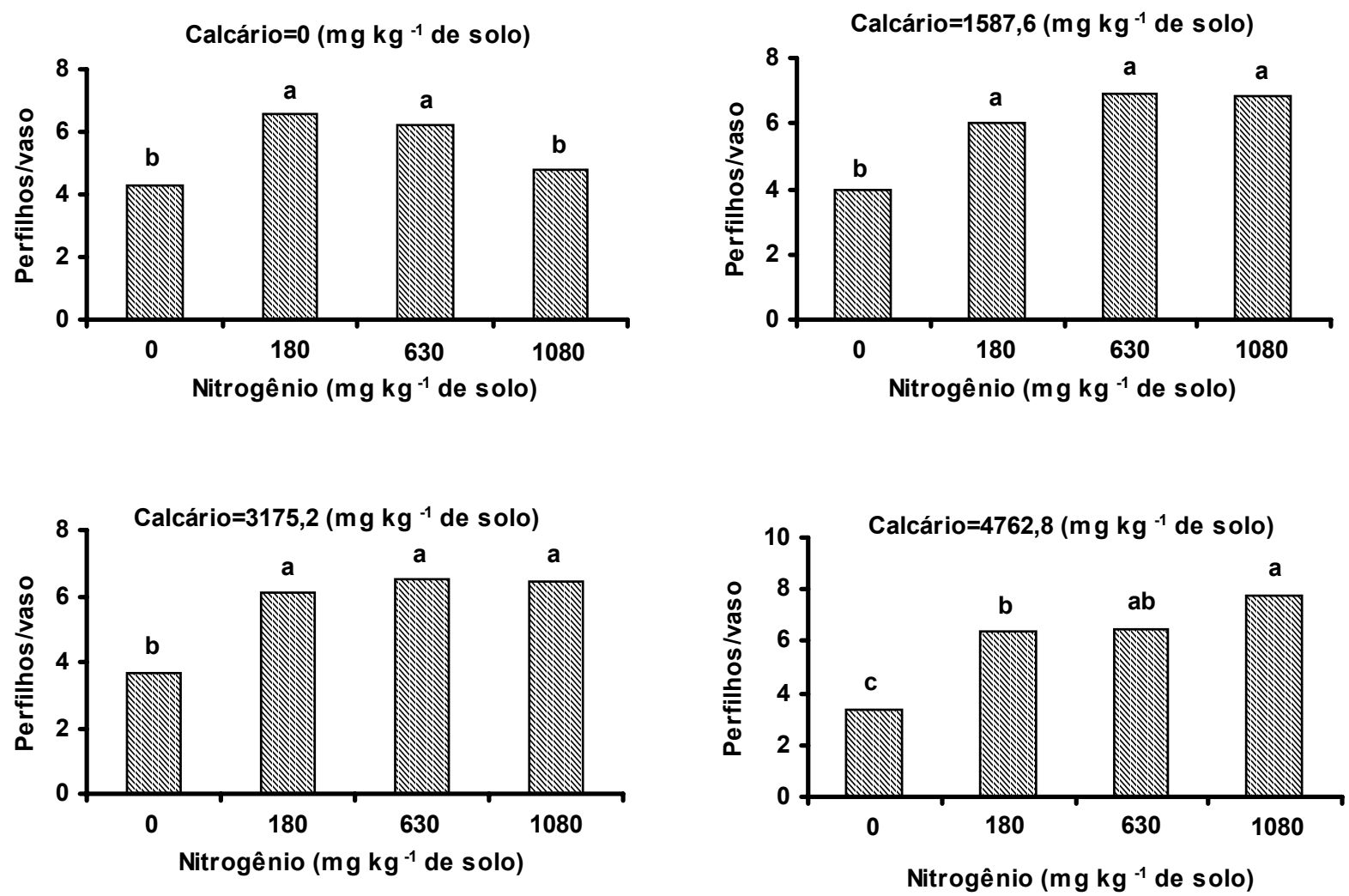

Figura 8 - Número de perfilhos/vaso na Brachiaria decumbens, no primeiro crescimento em função das doses de nitrogênio dentro de cada dose de calcário. Letras diferentes indicam significância ao nível de $5 \%$ de probabilidade. 
Observou-se que, o maior perfilhamento ocorreu nas maiores doses de nitrogênio e calcário. Isso demonstra que, para que haja maior eficiência de utilização do nitrogênio no perfilhamento da braquiária decumbens é necessário a aplicação de calcário, nesse tipo de solo. Isso provavelmente, se deve a uma elevação do $\mathrm{pH}$ que, favorece a mineralização da matéria orgânica e disponibiliza mais nitrogênio e fósforo, além do fornecimento de $\mathrm{Ca}$ e $\mathrm{Mg}$.

Esses resultados discordam do encontrado por Mitidieri (1995), que avaliando doses de calcário sobre o perfilhamento dos capins IZ-1, Vencedor, Centenário e Marandu, encontrou que as espécies diminuíram o perfilhamento no nível mais elevado de saturação por bases ( $\mathrm{V} \%=68,8)$, não encontrando diferenças significativas nos três níveis iniciais de saturação por bases. Por outro lado, aumento no número médio de perfilhos/planta/vaso até $37 \%$ de saturação por bases foi encontrado por Premazzi (1991), em capim Colonião.

No estudo dos efeitos das doses de calcário dentro das doses de nitrogênio, no primeiro crescimento, revelou-se significância $(P<0,05)$ para o calcário, apenas quando a dose de nitrogênio foi de $1080 \mathrm{mg} \mathrm{kg}^{-1}$ de solo. Nas doses de nitrogênio 0,180 e $630 \mathrm{mg} \mathrm{kg}^{-1}$ de solo, não se verificou significância $(P<0,05)$ para o calcário em termos de número de perfilhos totais nas plantas. Quando a dose de calcário foi de $4762,8 \mathrm{mg} \mathrm{kg}^{-1}$ de solo, verificou-se que o número de perfilhos foi maior, apesar de não ter havido diferença estatística (Figura 9). Os resultados mais uma vez mostram que o maior pefilhamento ocorreu nas maiores doses de nitrogênio e calcário utilizadas nesse estudo, comprovando a necessidade da calagem como fonte de nutrientes para a planta. 


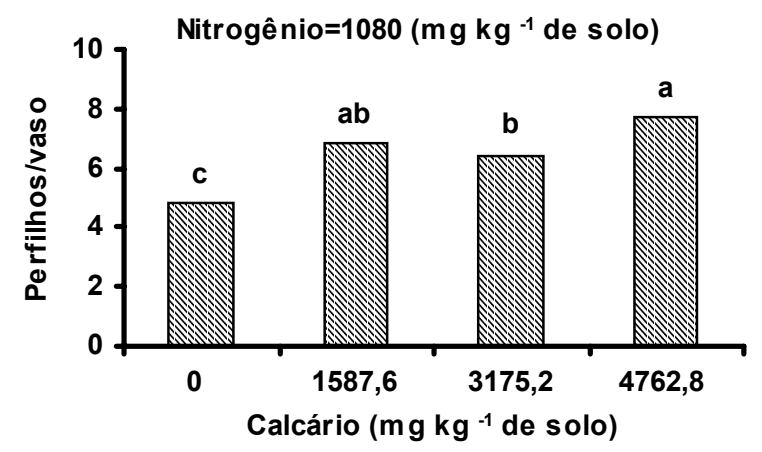

Figura 9 - Número de perfilhos/vaso na Brachiaria decumbens, no primeiro corte em função das doses de calcário dentro da dose de nitrogênio 1080 $\mathrm{mg} \mathrm{kg}^{-1}$ de solo. Letras diferentes indicam significância ao nível de $5 \%$ de probabilidade.

No segundo período de crescimento foi constatado significância $(P<0,05)$ para o número total de perfilhos para as doses de enxofre na dose de nitrogênio $630 \mathrm{mg} \mathrm{kg}^{-1}$ de solo dentro das doses 0 e $4762,8 \mathrm{mg} \mathrm{kg}^{-1}$ de solo de calcário (Figura 10). Também houve significância $(P<0,05)$ para as doses de enxofre dentro da dose $1080 \mathrm{mg} \mathrm{kg}^{-1}$ de solo de nitrogênio e $4762,8 \mathrm{mg} \mathrm{kg}^{-1}$ de solo de calcário (Figura 11). Os resultados mostram que quando se utiliza doses de nitrogênio e calcário maiores é necessário uma menor quantidade de enxofre para que essa planta alcance máximo perfilhamento. Esses resultados devem ser considerados como informações relevantes para um manejo mais adequado para essa braquiária quanto ao uso de calcário, nitrogênio e enxofre em condições de campo. 

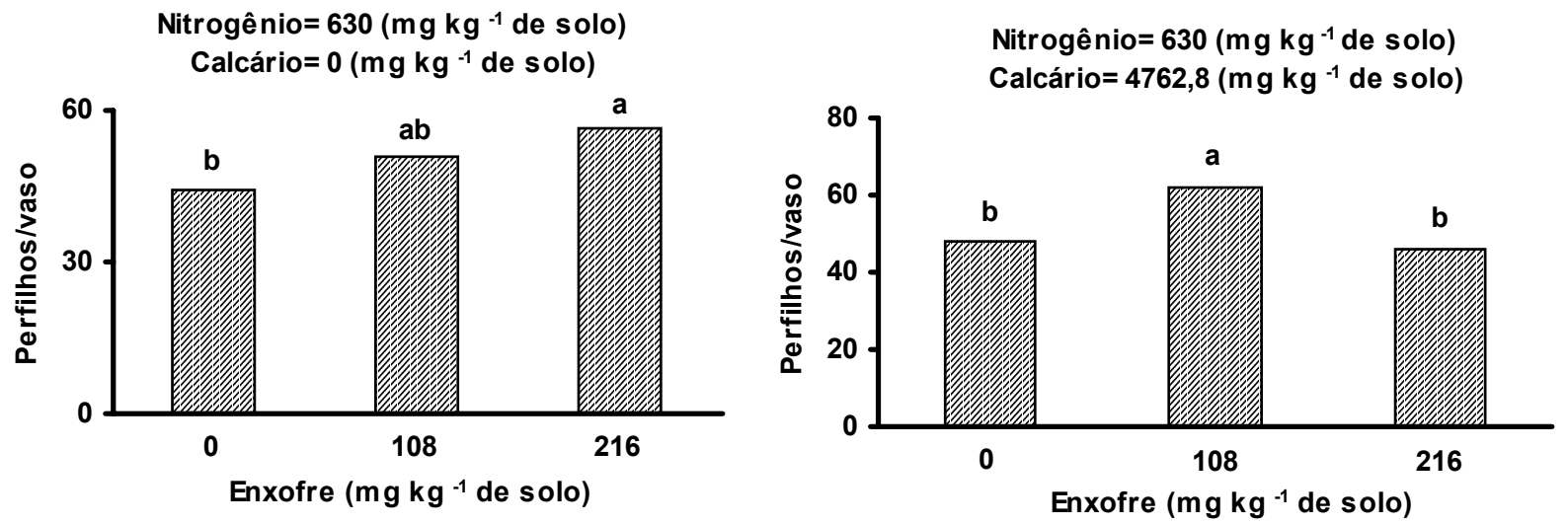

Figura10 - Número de perfilhos/vaso na Brachiaria decumbens, no segundo corte em função das doses de enxofre dentro da dose de nitrogênio $630 \mathrm{mg} \mathrm{kg}^{-1}$ de solo e das doses de calcário 0 e 4762,8 $\mathrm{mg} \mathrm{kg}^{-1}$ de solo. Letras diferentes indicam significância ao nível de $5 \%$ de probabilidade.

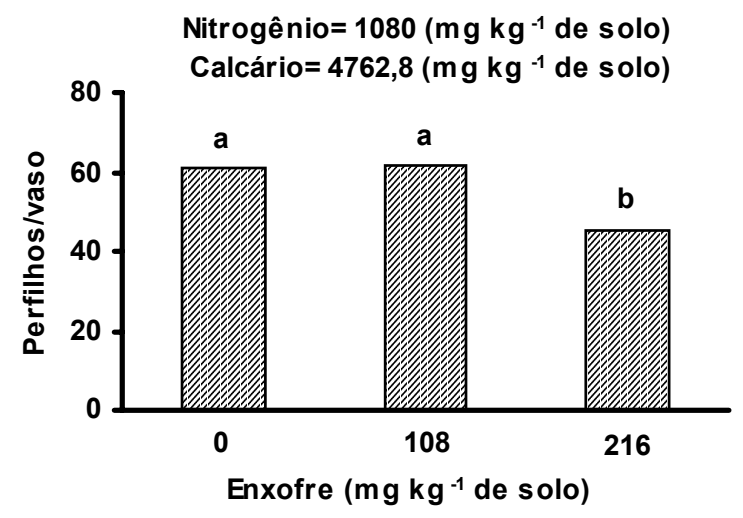

Figura 11 - Número de perfilhos/vaso na Brachiaria decumbens, no segundo corte em função das doses de enxofre dentro da dose de nitrogênio $1080 \mathrm{mg} \mathrm{kg}^{-1}$ de solo e da dose de calcário $4762,8 \mathrm{mg} \mathrm{kg}^{-1}$ de solo. Letras diferentes indicam significância ao nível de $5 \%$ de probabilidade.

Com relação ao nitrogênio, houve significância $(P<0,05)$ dentro da dose 0 de enxofre e de todas as doses de calcário para o perfilhamento da Brachiaria 
decumbens, no segundo período de crescimento (Figura 12). O perfilhamento também foi influenciado pelas doses de nitrogênio dentro da dose $108 \mathrm{mg} \mathrm{kg}^{-1}$ de solo de enxofre e de todas as doses de calcário (Figura 13). Para as doses de nitrogênio dentro da dose $216 \mathrm{mg} \mathrm{kg}^{-1}$ de solo de enxofre foi significativo $(P<0,05)$ apenas para as doses de calcário $0,1587,6$ e $3175,2 \mathrm{mg} \mathrm{kg}^{-1}$ de solo (Figura 14).
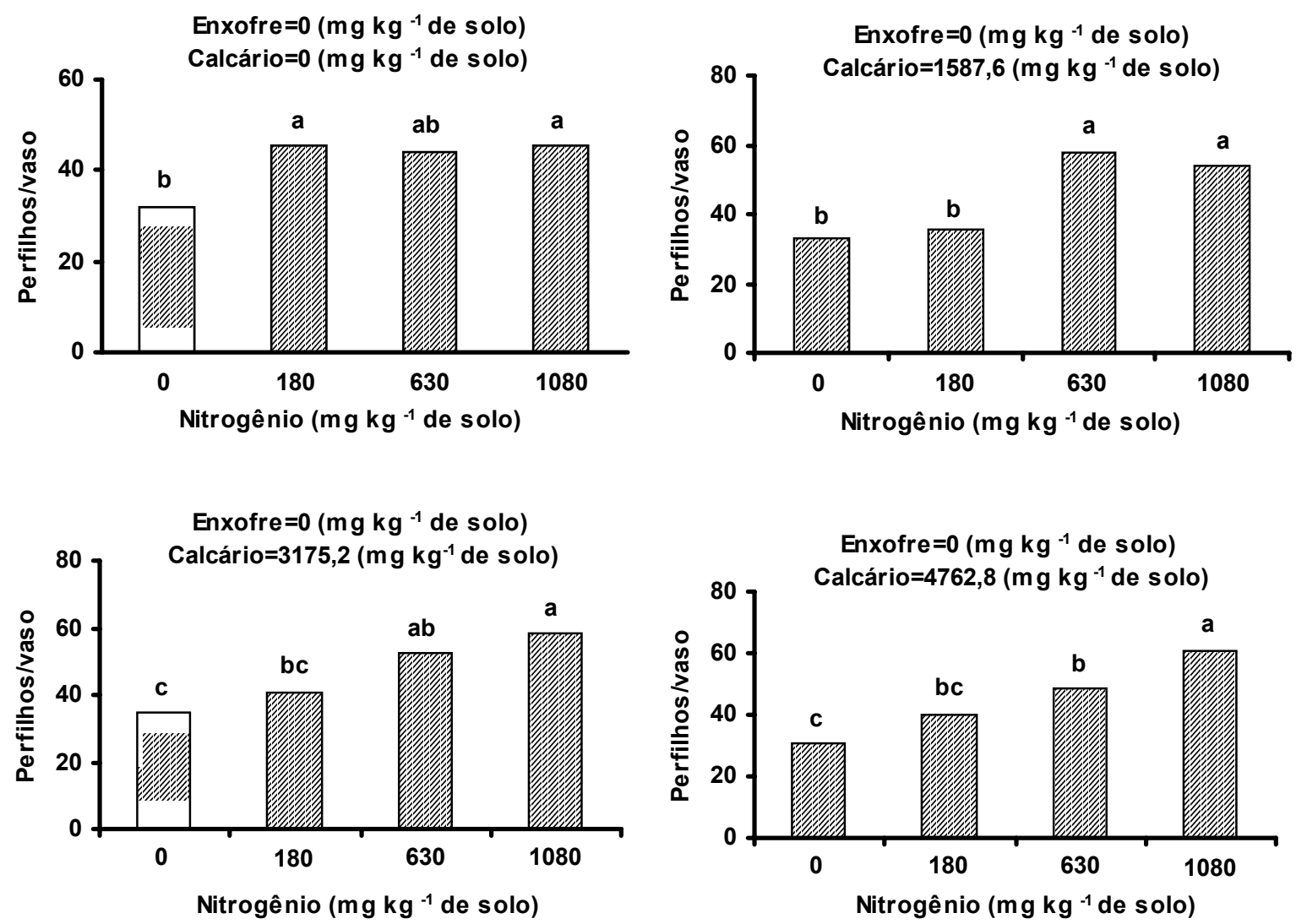

Figura 12 - Número de perfilhos/vaso na Brachiaria decumbens, no segundo corte em função das doses de nitrogênio dentro da dose de enxofre 0 $\mathrm{mg} \mathrm{kg}^{-1}$ e de todas as doses de calcário. Letras diferentes indicam significância ao nível de $5 \%$ de probabilidade. 

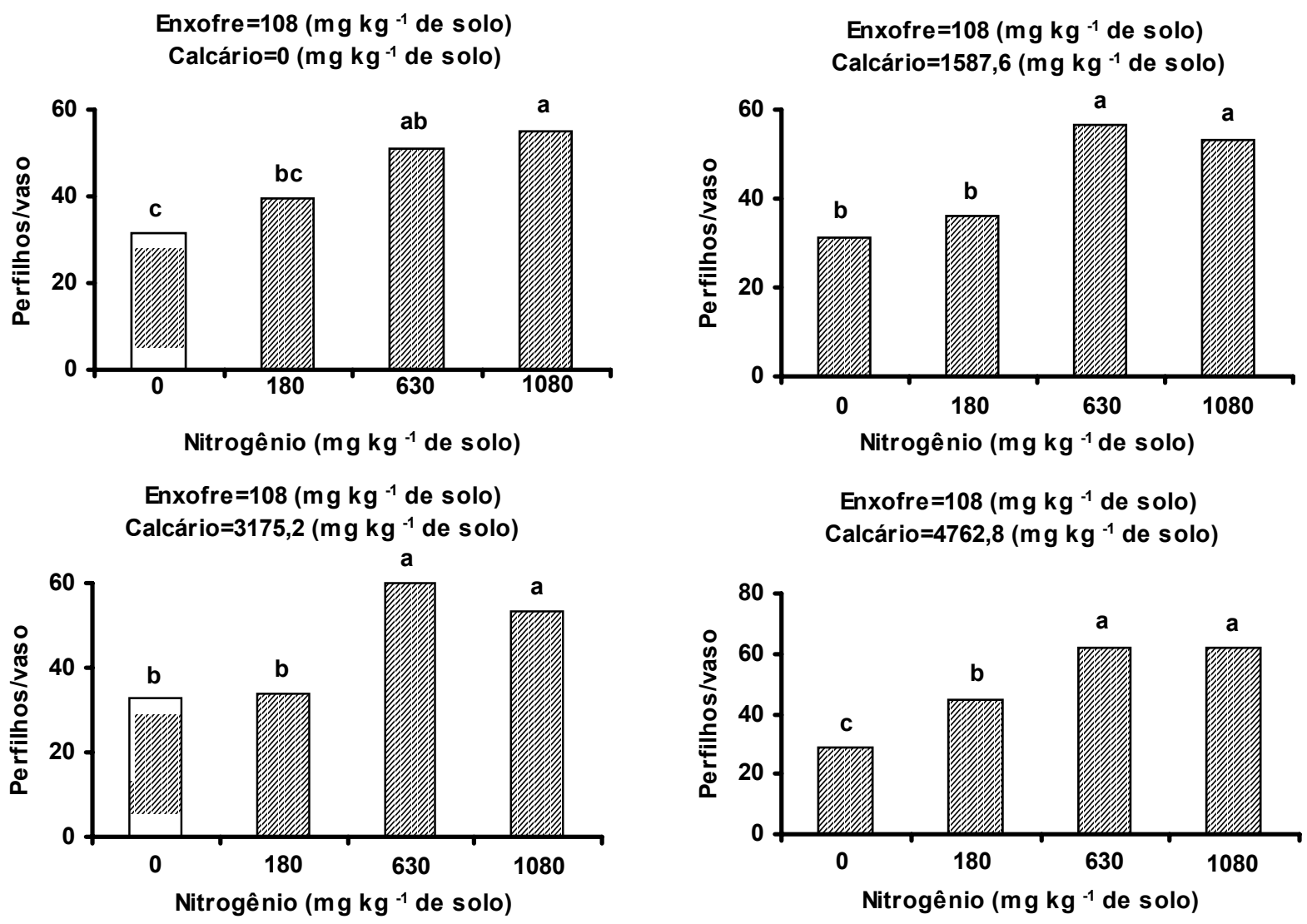

Figura 13 - Número de perfilhos/vaso na Brachiaria decumbens, no segundo corte em função das doses de nitrogênio dentro da dose de enxofre $108 \mathrm{mg} \mathrm{kg}^{-1}$ de solo e de todas as doses de calcário. Letras diferentes indicam significância ao nível de $5 \%$ de probabilidade. 

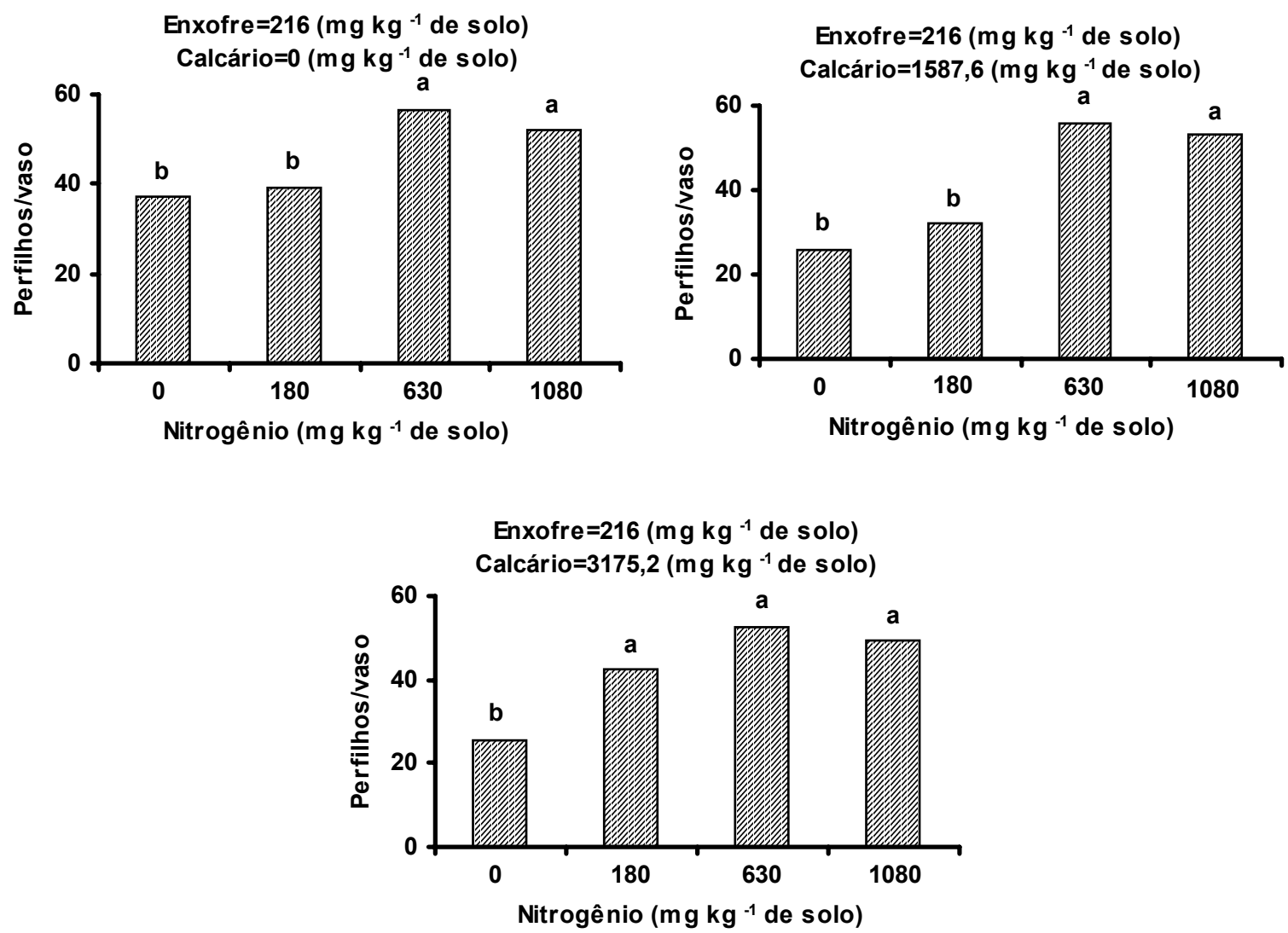

Figura 14 - Número de perfilhos/vaso na Brachiaria decumbens, no segundo corte em função das doses de nitrogênio dentro da dose de enxofre $216 \mathrm{mg} \mathrm{kg}^{-1}$ de solo e das doses de calcário 0, 1587,6 e 3175,2 mg $\mathrm{kg}^{-1}$ de solo. Letras diferentes indicam significância ao nível de $5 \%$ de probabilidade.

Com relação ao calcário, houve significância $(P<0,05)$ apenas na dose de enxofre $0 \mathrm{mg} \mathrm{kg}^{-1}$ de solo dentro das doses de calcário 1587,6 e 4762,8 mg $\mathrm{kg}^{-1}$ de solo (Figura 15). Os resultados indicam que a aplicação de doses maiores de enxofre e calcário integrados promovem maiores respostas do nitrogênio quanto ao perfilhamento. 

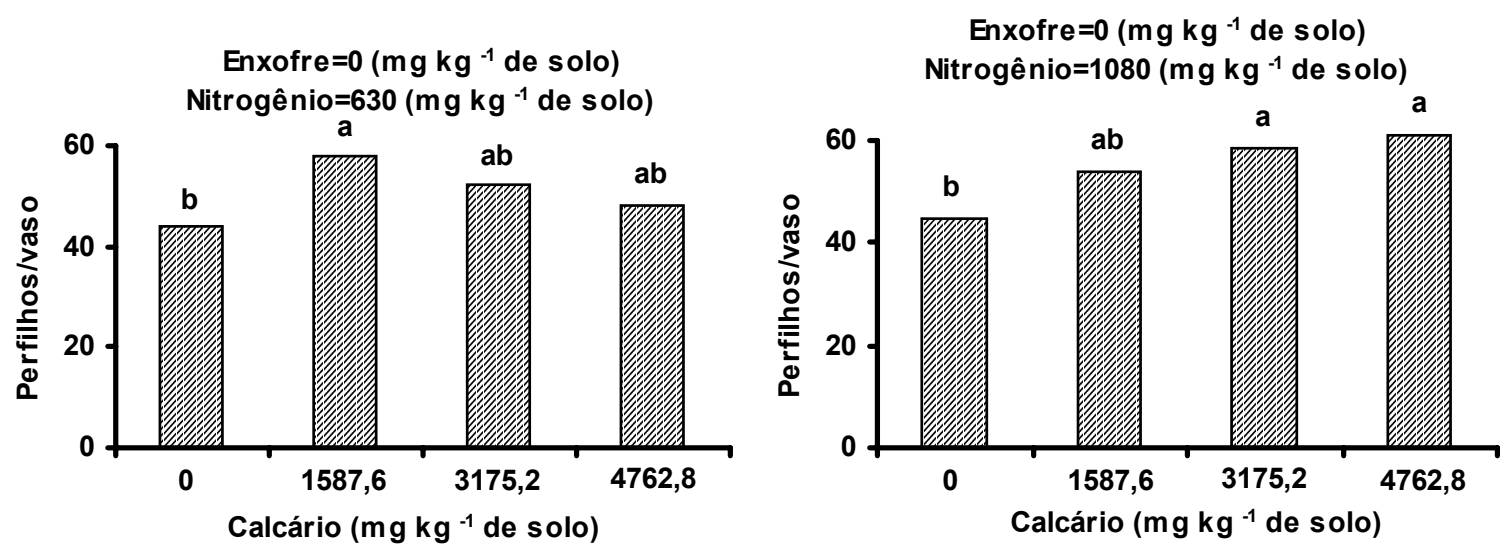

Figura 15 - Número de perfilhos/vaso na Brachiaria decumbens, no segundo corte em função das doses de calcário dentro da dose de enxofre 0 $\mathrm{mg} \mathrm{kg}^{-1}$ de solo e das doses de nitrogênio 630 e $1080 \mathrm{mg} \mathrm{kg}^{-1} \mathrm{de}$ solo. Letras diferentes indicam significância ao nível de $5 \%$ de probabilidade.

O maior perfilhamento das plantas ocorreu no segundo período de crescimento. Essa observação com relação aos perfilhos é compatível com os máximos de produção de matéria seca obtidos, no segundo corte. Isto pode ser justificado pelo fato de no segundo crescimento, as plantas já estarem estabelecidas e com maior volume radicular possibilitando maior absorção de nutrientes pelas raízes, como também pelo fato de terem sofrido a ação do corte que acaba promovendo a indução das gemas basais.

\section{4 Área foliar}

A área foliar total por vaso da braquiária foi influenciada $(P<0,05)$ pela interação entre as doses de nitrogênio e calcário nas duas avaliações e pelas doses de nitrogênio no segundo crescimento. As doses de nitrogênio na segunda avaliação, tiveram efeitos representados por uma equação de 
segundo grau e, derivando-se essa equação, verificou-se que o maior valor da área foliar total foi obtido na dose de nitroaênio $960.2 \mathrm{ma} \mathrm{ka}^{-1}$ de solo (Figura 16).

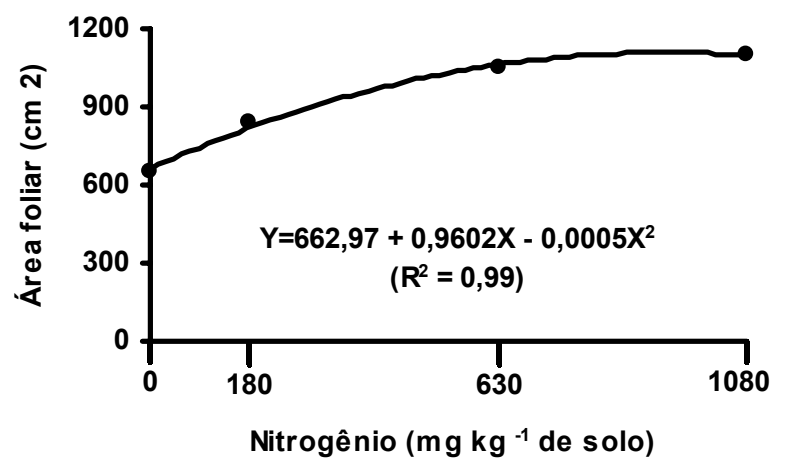

Figura 16 - Área foliar total da Brachiaria decumbens, no segundo crescimento, em função das doses de nitrogênio.

No desdobramento das doses de nitrogênio dentro de cada dose de calcário verificou-se efeito $(P<0,05)$ para todas as doses de calcário, no primeiro e segundo crescimentos (Figura 17). Esse efeito se ajustou a uma equação de segundo grau para a dose de calcário $1587,6 \mathrm{mg} \mathrm{kg}^{-1}$ de solo e o ponto de máxima área foliar total seria obtido na dose de nitrogênio $1134 \mathrm{mg} \mathrm{kg}^{-1}$ de solo, dentro da respectiva dose de calcário. As demais doses se ajustaram a um modelo linear, no primeiro corte. No segundo corte, as doses de calcário 1587,6 e $4762,8 \mathrm{mg} \mathrm{kg}^{-1}$ de solo, tiveram ajustes a um modelo linear, enquanto as doses 0 e $3175,2 \mathrm{mg} \mathrm{kg}^{-1}$ de solo se ajustaram a um modelo quadrático. Os pontos de máxima foram obtidos em 567,2 e $776,1 \mathrm{mg} \mathrm{kg}^{-1}$ de solo. 

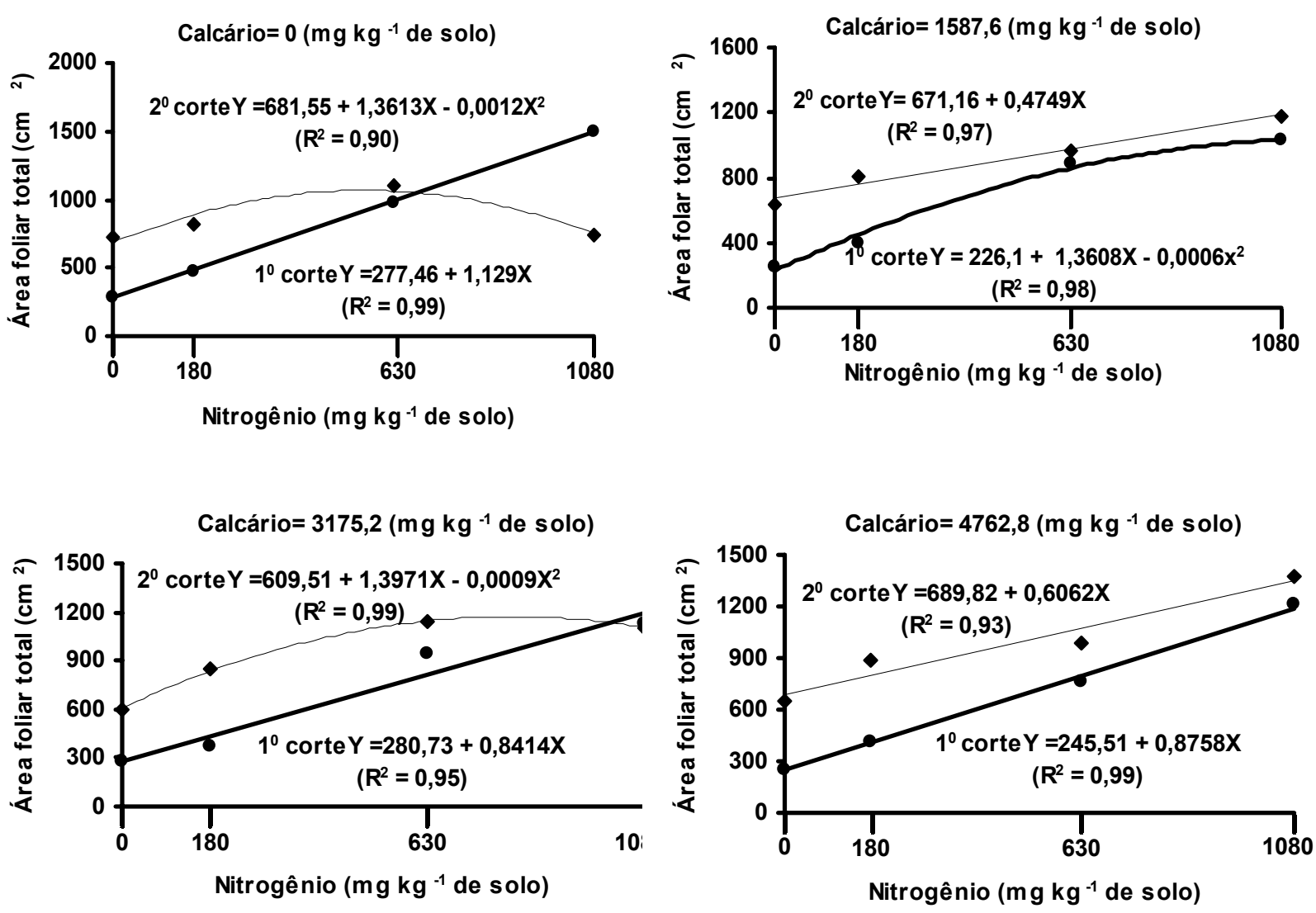

Figura 17 - Área foliar total da Brachiaria decumbens, no primeiro e segundo crescimentos, em função das doses de nitrogênio dentro de cada dose de calcário.

No estudo das doses de calcário dentro de cada dose de nitrogênio verificou-se efeito significativo $(P<0,05)$ apenas para as doses de nitrogênio 630 $\mathrm{mg} \mathrm{kg}^{-1}$ de solo, no primeiro corte e para a dose $1080 \mathrm{mg} \mathrm{kg}^{-1}$ de solo, no primeiro e segundo crescimentos (Figura 18). Esses efeitos ajustaram-se a um equação de primeiro grau na dose de nitrogênio de $630 \mathrm{mg} \mathrm{kg}^{-1}$ de solo e a uma equação de segundo grau na dose $1080 \mathrm{mg} \mathrm{kg}^{-1}$ de solo, no primeiro corte. $\mathrm{O}$ ponto de mínima foi obtido na dose de calcário de $3136 \mathrm{mg} \mathrm{kg}^{-1}$ de solo dentro da respectiva dose de nitrogênio. A dose de nitrogênio1080 $\mathrm{mg} \mathrm{kg}^{-1}$ de solo, no segundo corte teve comportamento linear. 

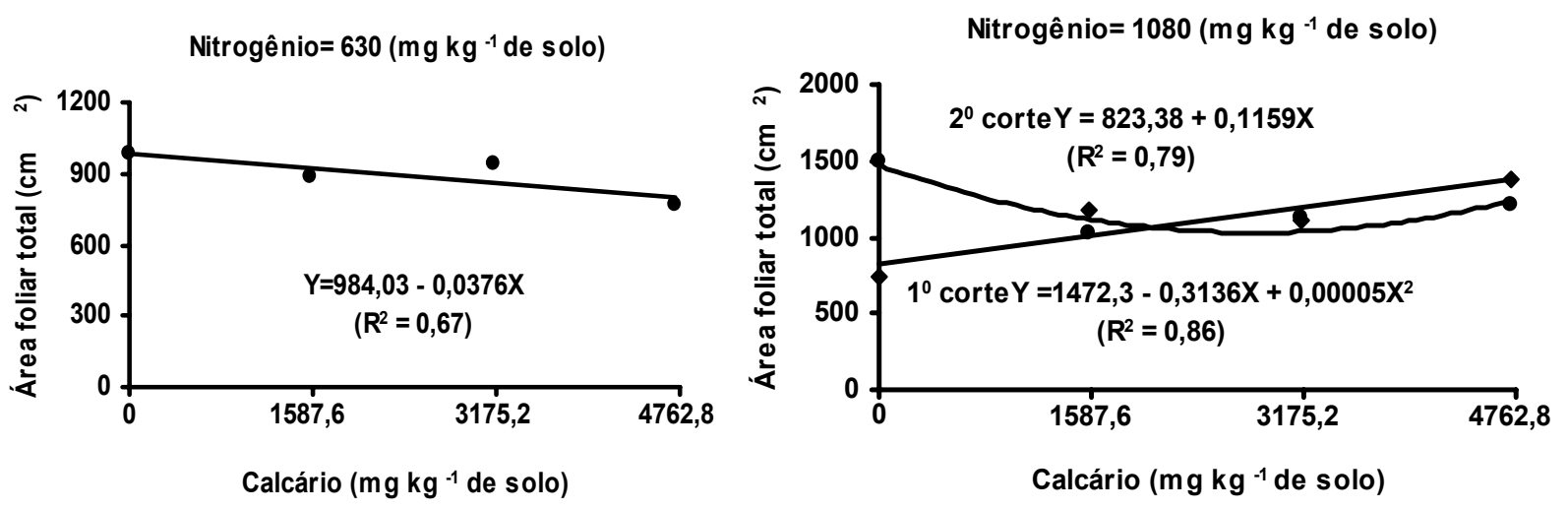

Figura 18 - Área foliar total da Brachiaria decumbens, em função das doses de calcário dentro das doses de nitrogênio $630 \mathrm{mg} \mathrm{kg}^{-1}$ de solo, no primeiro corte e $1080 \mathrm{mg} \mathrm{kg}^{-1}$ de solo, nos dois cortes.

O comportamento linear ou quadrático, na maioria dos casos, com exceção da dose 0 de nitrogênio dentro da dose 0 de calcário, no segundo corte e doses de calcário dentro da dose de nitrogênio de $1080 \mathrm{mg} \mathrm{kg}^{-1}$ de solo, no primeiro corte, indicam que as doses de nutrientes propostas nesse estudo não foram suficientes para que a planta atingisse a máxima área foliar. Os resultados desse estudo, mais uma vez, confirmam, a importância do nitrogênio e, também da calagem sobre a produção de plantas forrageiras .

De acordo com Gastal \& Nelson (1984), o efeito do nitrogênio sobre a taxa de alongamento foliar, decorre do maior acúmulo desse nutriente na zona de alongamento da folha, mais precisamente na região de divisão celular. Esses mesmos autores, encontraram uma alta correlação entre a quantidade de nitrogênio contido nessa região e a taxa de expansão foliar. Manarin (2000) também verificou efeitos significativos de doses de nitrogênio sobre a área foliar do capim-Mombaça. Mattos (2001), encontrou interação significativa $(P<0,01)$ para o nitrogênio e o enxofre para a área foliar no primeiro e terceiro crescimentos das plantas de braquiária. 


\subsection{Estimativa do teor de clorofila pelo valor SPAD}

Os resultados das leituras de clorofila obtidas através do Chlorophyll Meter SPAD na lâmina foliar da braquiária, revelou efeito significativo $(P<0,05)$ para as doses de nitrogênio, no primeiro e segundo corte. Esse efeito foi explicado por um modelo quadrático, no primeiro corte e por um modelo linear no segundo. Derivando-se a equação de regressão, verificou-se que o máximo valor SPAD obtido, ocorreu na dose $1025 \mathrm{mg} \mathrm{kg}^{-1}$ de solo (Figura 19). O valor SPAD encontrado com a dose máxima de nitrogênio utilizada neste estudo foi de 52,23 . No segundo crescimento o teor de clorofila ainda, sofreu variação significativa $(P<0,05)$ em função das doses de enxofre. $O$ resultado foi representado por um modelo linear (Figura 20).

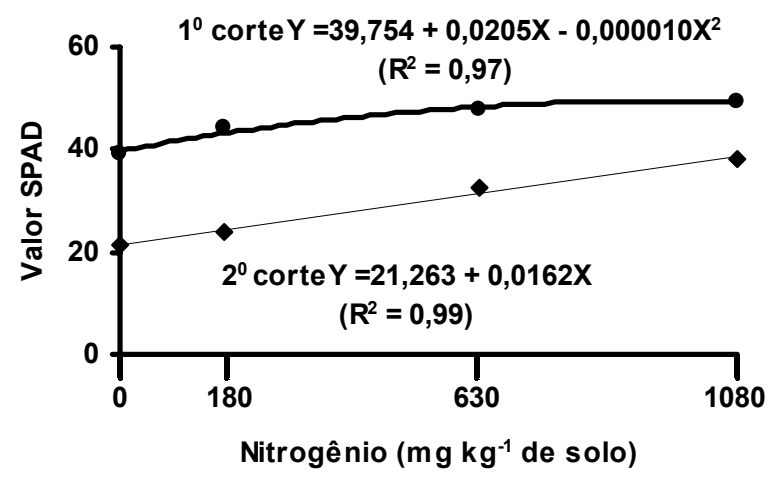

Figura 19 - Valor SPAD na Brachiaria decumbens, no primeiro e segundo corte, em função das doses de nitrogênio. 


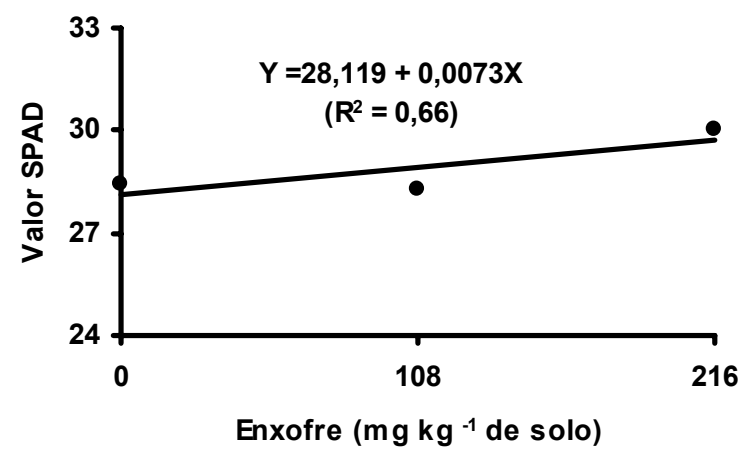

Figura 20 - Valor SPAD na Brachiaria decumbens, no segundo crescimento, em função das doses de enxofre.

Resultados semelhantes foram obtidos por Santos (1997) que obteve, para o primeiro e segundo crescimentos de Brachiaria decumbens, o teor de clorofila, expresso em valor SPAD, entre 50,2 e 52,0 respectivamente. Colozza (1998) obteve valores críticos de nitrogênio entre 32,0 e 38,6 unidades SPAD para o capim-Mombaça. Manarin (2000) trabalhando com o mesmo capim, obteve valores entre 41 e 45 unidades SPAD para o ponto crítico de nitrogênio nas folhas recém-expandidas. Trabalhando com o capim-Tifton 85, Premazzi (2001), encontrou valores de 39,4 e 44,2 unidades SPAD.

\subsection{Concentração de macronutrientes nos componentes da parte aérea}

\subsubsection{Nitrogênio}

A concentração de nitrogênio nas folhas emergentes da braquiária revelou efeito significativo $(P<0,05)$ para as doses de nitrogênio no primeiro e segundo cortes e interação entre doses de nitrogênio e calcário apenas no primeiro corte. Os efeitos das doses de nitrogênio ajustaram-se a um modelo quadrático em ambos os casos (Figura 21). Os pontos de máxima concentração de nitrogênio nesse componente da planta foram obtidos nas doses 868 e 1069 $\mathrm{mg} \mathrm{kg}^{-1}$ de solo. A concentração de nitrogênio no tecido em função da adubação nitrogenada variou de 10,70 a $35,38 \mathrm{~g} \mathrm{~kg}^{-1}$ na matéria seca. A maior 
concentração ocorreu na maior dose do nutriente, no segundo corte. Essa maior concentração de nitrogênio no tecido no segundo corte, deve-se a melhor eficiência de utilização da planta promovida pelo corte, além do fato desse elemento ser altamente móvel e se concentrar, principalmente nos orgãos mais novos das plantas.

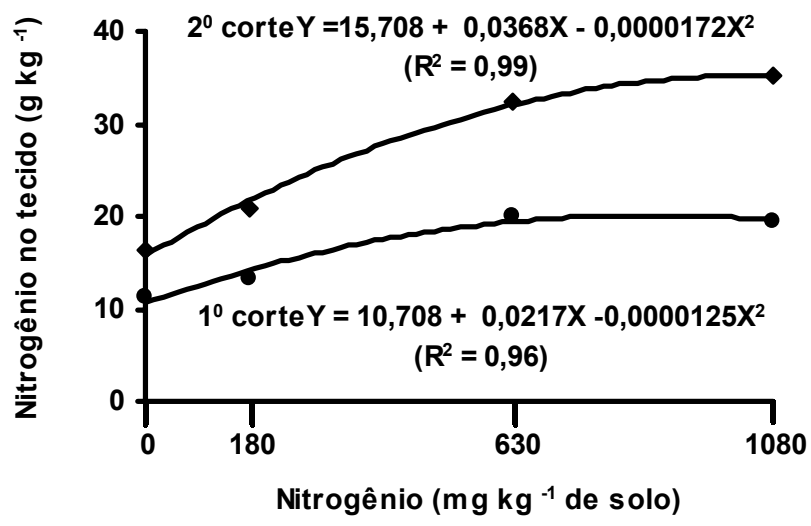

Figura 21 - Concentração de nitrogênio nas folhas emergentes da braquiária em função das doses de nitrogênio aplicadas, no primeiro e segundo cortes.

Avaliando as doses de nitrogênio dentro das doses de calcário, observou-se significância $(\mathrm{P}<0,05)$ para todas as doses de calcário. Os resultados foram demonstrados por um modelo linear nas doses 0 e 1587,6 e por um modelo quadrático nas doses 3175,2 e $4762,8 \mathrm{mg} \mathrm{kg}^{-1}$ de solo, com os pontos de máxima encontrados nas doses 729 e 1290 (Figura 22). 

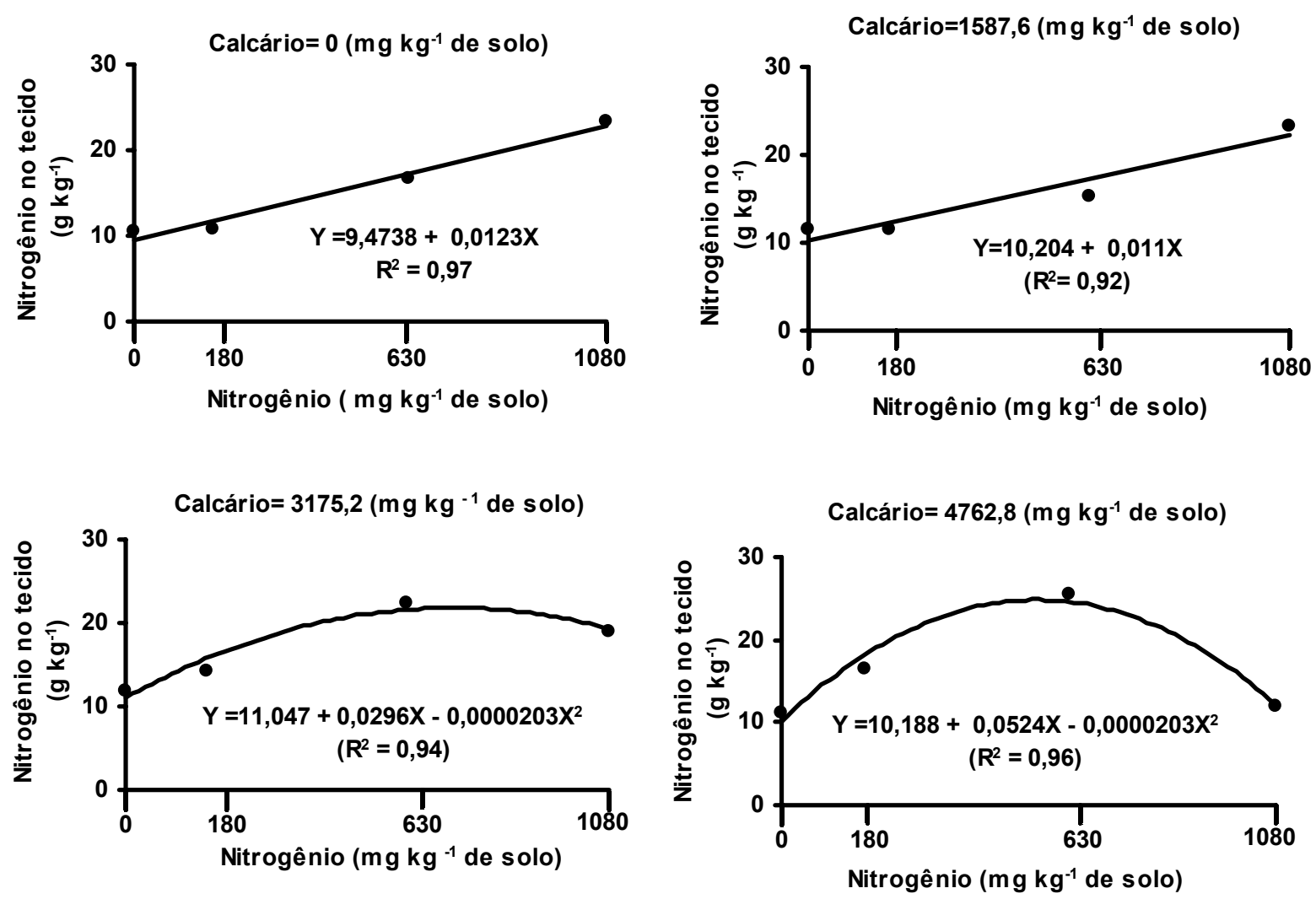

Figura 22 - Concentração de nitrogênio nas folhas emergentes da Brachiaria decumbens, no primeiro crescimento em função das doses de nitrogênio dentro de cada dose de calcário.

Já nas doses de calcário dentro das doses de nitrogênio houve efeito significativo $(P<0,05)$ apenas nas doses de nitrogênio 180,630 e $1080 \mathrm{mg} \mathrm{kg}^{-1}$ de solo. Esses efeitos foram demonstrados por um modelo linear nos dois primeiros casos e por um modelo quadrático na dose de nitrogênio de $1080 \mathrm{mg}$ $\mathrm{kg}^{-1}$ de solo, com o ponto de máxima obtido na dose de calcário de $714 \mathrm{mg} \mathrm{kg}^{-1}$ de solo dentro da respectiva dose de nitrogênio (Figura 23). 

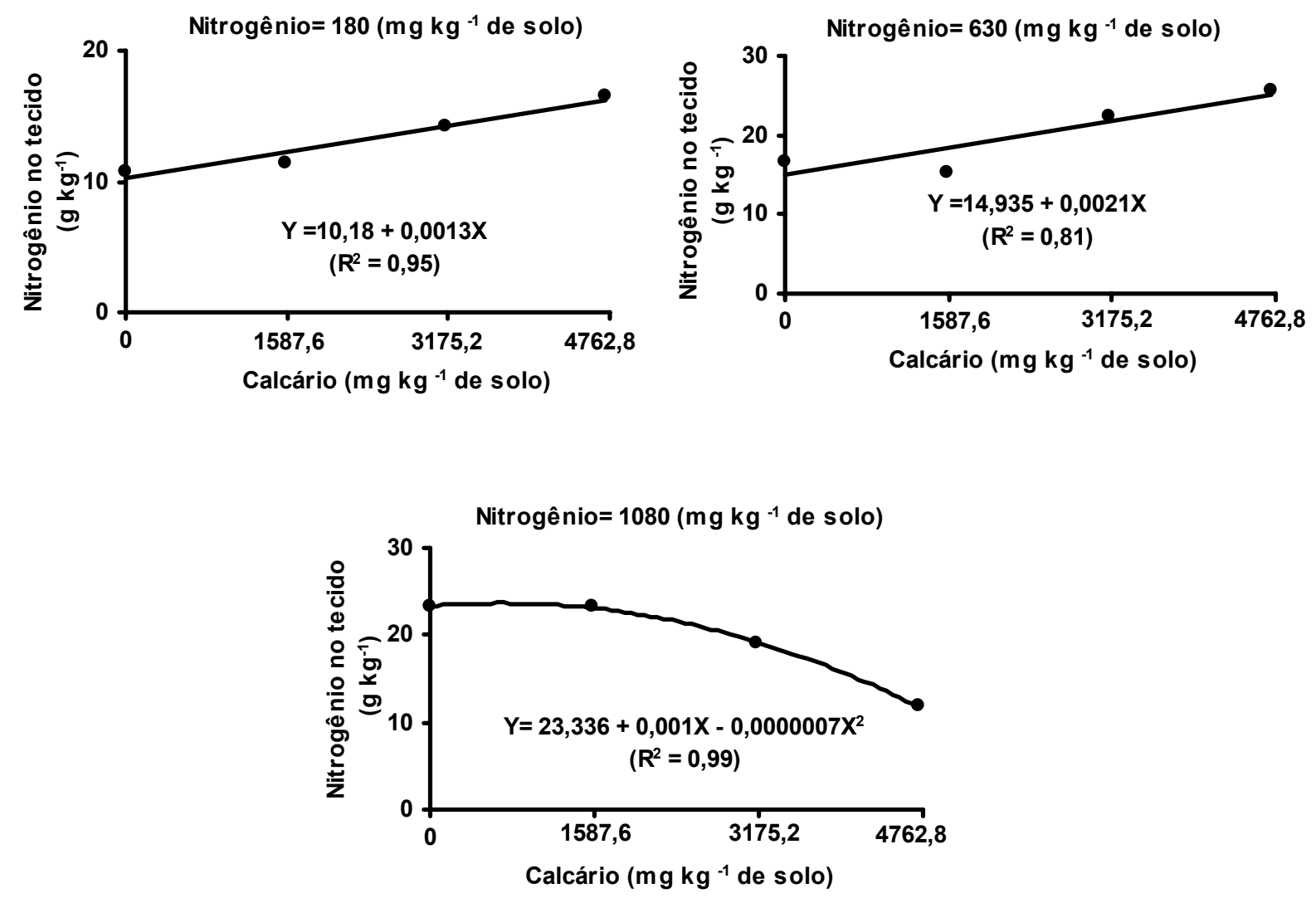

Figura 23 - Concentração de nitrogênio nas folhas emergentes da Brachiaria decumbens, no primeiro crescimento em função das doses de calcário dentro das doses 180, 630 e $1080 \mathrm{mg} \mathrm{kg}^{-1}$ de solo de nitrogênio.

No segundo corte também houve efeito significativo $(P<0,05)$ para as doses de enxofre. $O$ efeito das doses de enxofre na concentração de nitrogênio no tecido se ajustou a um modelo linear de regressão (Figura 24). Esses resultados permite inferir que maior concentração de nitrogênio nas folhas emergentes da braquiária poderão ser obtidas se doses de enxofre maiores que as avaliadas nesse estudo forem utilizadas. 


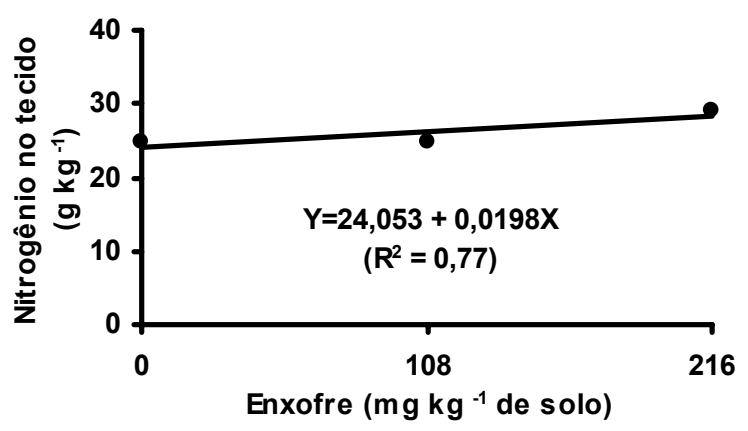

Figura 24 - Concentração de nitrogênio nas folhas emergentes da Brachiaria decumbens, no primeiro crescimento em função das doses de enxofre.

Através das equações de regressão pode-se constatar que, a variação na concentração de nitrogênio nesse tecido vegetal foi de 9,47 a 43,10 $\mathrm{g} \mathrm{kg}^{-1}$ na matéria seca, respectivamente na interação das menores e maiores doses de nitrogênio e calcário, no primeiro crescimento.

Santos (1997), observou que a concentração de nitrogênio neste componente da parte aérea apresentou respostas significativas para as doses de nitrogênio na solução nutritiva, no capim-braquiária.

A concentração de nitrogênio nas lâminas de folhas recém expandidas foi influenciada significativamente $(P<0,05)$ pelas doses de nitrogênio e pela interação entre nitrogênio e calcário, na primeira e segunda avaliação da braquiária.

Os efeitos das doses de nitrogênio tanto no primeiro como no segundo cortes ajustaram-se a um modelo quadrático (Figura 25). Os valores de máxima concentração nesse componente da planta foram obtidos nas doses de nitrogênio 797 e 992,7 mg kg-1 de solo, respectivamente. A variação na concentração de nitrogênio no tecido em função da adubação nitrogenada foi de 11,31 a $36,35 \mathrm{~g} \mathrm{~kg}^{-1}$ na matéria seca. A maior concentração do nutriente ocorreu na maior dose, no segundo corte. 


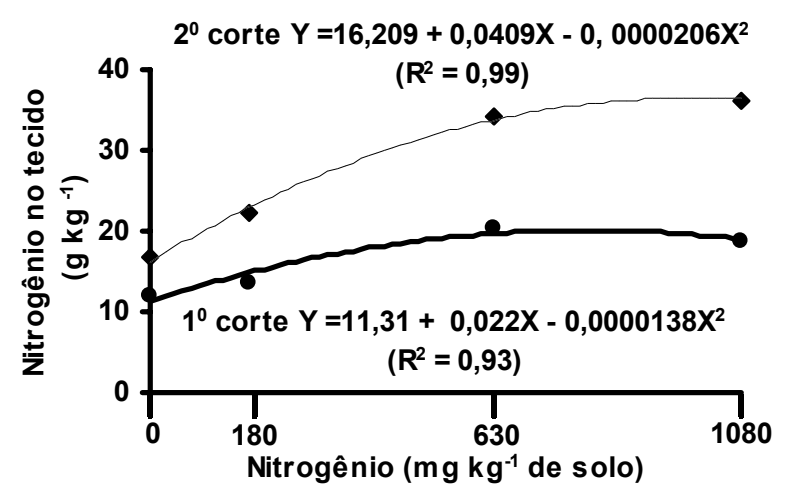

Figura 25 - Concentração de nitrogênio nas lâminas de folhas recém expandidas da Brachiaria decumbens, no primeiro e segundo crescimento em função das doses de nitrogênio.

No estudo das doses de nitrogênio dentro de cada dose de calcário, observou-se significância $(P<0,05)$ para o nitrogênio dentro de todas as doses de calcário nas duas avaliações. Os resultados se ajustaram a um modelo linear nas doses 0 e 1587,6 e a um modelo quadrático nas doses 3175,2 e $4762,8 \mathrm{mg} \mathrm{kg}^{-1}$ de solo, na primeira avaliação. Os valores de máxima foram obtidos nas doses 541 e $548 \mathrm{mg} \mathrm{kg}^{-1}$ de solo. Já no segundo corte, as doses 0 , 1587,6 e 3175,2 tiveram ajustes a um modelo linear, enquanto a dose 4762,8 $\mathrm{mg} \mathrm{kg}^{-1}$ de solo, teve ajuste a um modelo quadrático. $\mathrm{O}$ ponto de máxima concentração de nitrogênio foi obtido na dose $642 \mathrm{mg} \mathrm{kg}^{-1}$ de solo (Figura 26 ). A variação foi de 10,22 a $41,89 \mathrm{~g} \mathrm{~kg}^{-1}$ na matéria seca, na combinação das doses de nitrogênio e calcário. 

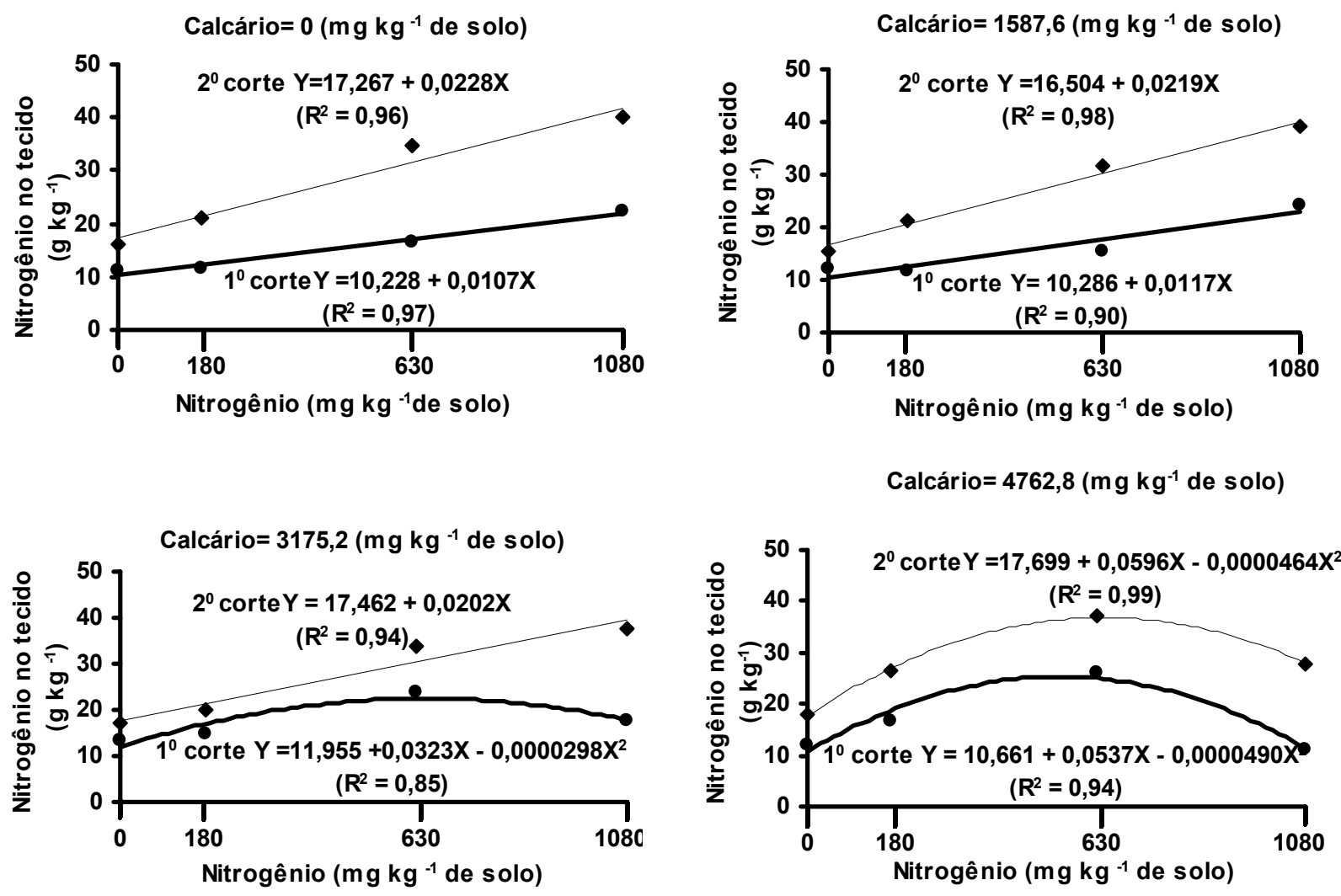

Figura 26 - Concentração de nitrogênio nas lâminas de folhas recém expandidas da Brachiaria decumbens, no primeiro e segundo crescimento em função das doses de nitrogênio dentro de cada dose de calcário.

$\mathrm{Na}$ avaliação das doses de calcário dentro de cada dose de nitrogênio, foi observado efeito significativo $(P<0,05)$ para as doses 180, 630 e $1080 \mathrm{mg}$ $\mathrm{kg}^{-1}$ de solo, no segundo corte (Figura 27) e apenas para a dose $1080 \mathrm{mg} \mathrm{kg}^{-1}$ de solo, no primeiro corte (Figura 28). Esses efeitos foram demonstrados por uma equação de primeiro grau para as doses 180 e 630, no segundo corte e por uma equação de segundo grau para a dose $1080 \mathrm{mg} \mathrm{kg}^{-1}$ de solo nos dois cortes (Figura 28). A máxima concentração de nitrogênio nas lâminas de folhas 
recém expandidas da braquiária ocorreu em 937,5 e $1000 \mathrm{mg} \mathrm{kg}^{-1}$ de solo, no primeiro e segundo cortes, respectivamente.
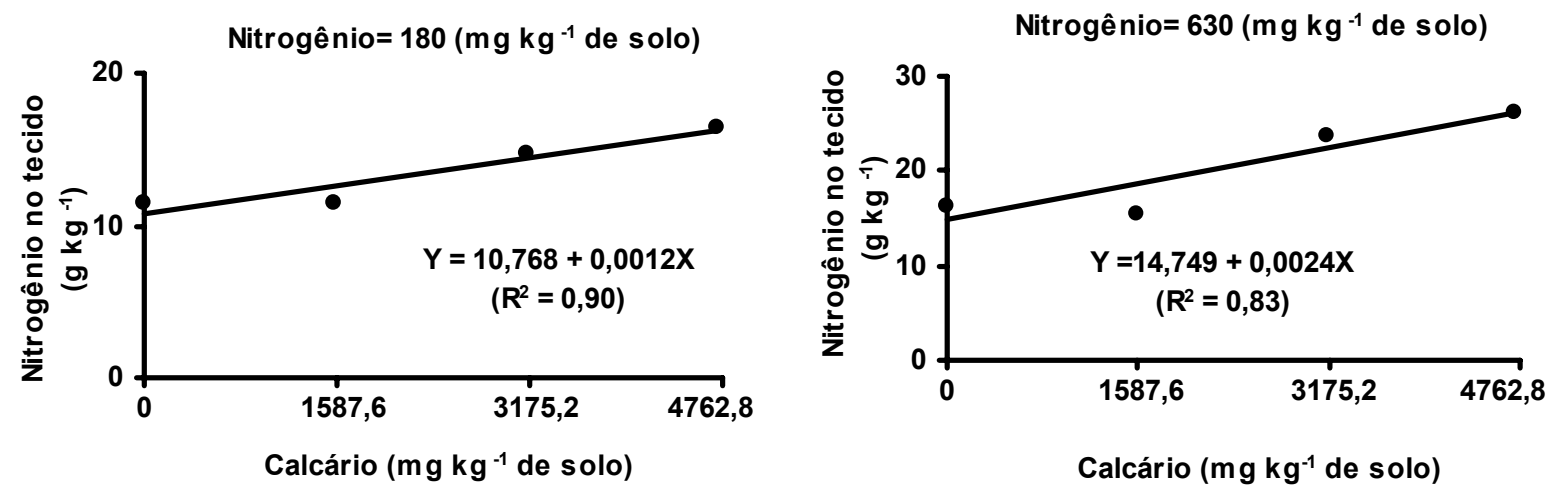

Figura 27 - Concentração de nitrogênio nas lâminas de folhas recém expandidas da Brachiaria decumbens, no segundo crescimento em função das doses de calcário dentro das doses de nitrogênio 180 e $630 \mathrm{mg} \mathrm{kg}^{-1}$ de solo.

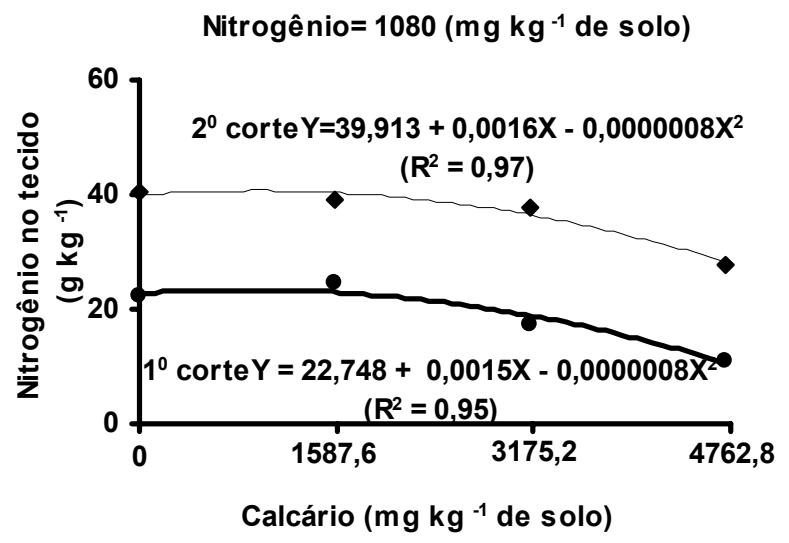

Figura 28 - Concentração de nitrogênio nas lâminas de folhas recém expandidas da Brachiaria decumbens, no primeiro e segundo crescimentos, em função das doses de calcário dentro da dose 1080 de nitrogênio $\mathrm{mg} \mathrm{kg}^{-1}$ de solo. 
Os teores de nitrogênio no tecido, em função da interação calcário e nitrogênio, variaram de 10,76 a 40,43 $\mathrm{g} \mathrm{kg}^{-1}$. Observou-se que a maior concentração ocorreu na menor dose de calcário dentro da mais alta dose de nitrogênio, no segundo crescimento das plantas.

Os valores encontrados nesse estudo foram superiores aos encontrados por Santos (1997), que verificou para este componente, no capim-braquiária teores de 12,6 a 27,5 $\mathrm{g} \mathrm{kg}^{-1}$. Ferragine \& Monteiro (1999) obtiveram para lâminas de folhas recém-expandidas do mesmo capim submetido a doses de nitrogênio e potássio, modelos quadráticos de regressão. Resultados diferentes dos encontrados por Mattos (2001) avaliando doses de nitrogênio e enxofre no capim-braquiária, observou um comportamento linear das doses de nitrogênio na concentração do elemento no tecido da planta.

Foi observado efeito significativo $(P<0,05)$ de doses de nitrogênio e interação nitrogênio calcário no primeiro e segundo crescimentos da braquiária sobre a concentração de nitrogênio nas lâminas de folhas maduras.

Os efeitos das doses de nitrogênio, no primeiro e segundo cortes se ajustaram a um modelo quadrático, com os pontos de máxima concentração do nutriente no tecido obtidos nas doses de nitrogênio 811,3 e $937,5 \mathrm{mg} \mathrm{kg}^{-1}$ de solo (Figura 29). A variação foi de 10,41 a $35,30 \mathrm{~g} \mathrm{~kg}^{-1}$, sendo o maior valor encontrado na mais alta dose do nutriente, no segundo corte. 


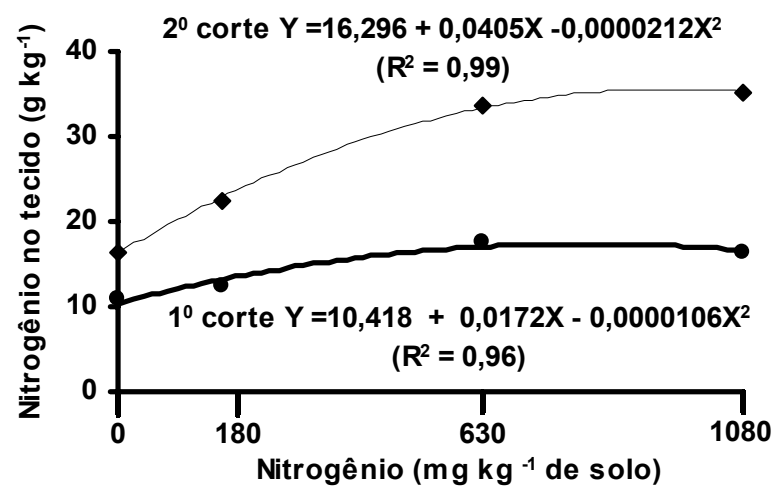

Figura 29 - Concentração de nitrogênio nas lâminas de folhas maduras da braquiária, no primeiro e segundo crescimentos em função das doses de nitrogênio.

Avaliando as doses de nitrogênio dentro de cada dose de calcário foi observado significância $(P<0,05)$ para as doses de calcário $0,1587,6$ e 4762,8 $\mathrm{mg} \mathrm{kg}^{-1}$ de solo, na primeira avaliação, enquanto que na segunda avaliação todas as doses foram significativas. Os resultados tiveram ajustes a um modelo linear na dose 0 e a um modelo quadrático nas doses 1587,6 e 4762,8 mg kg-1 de solo. $O$ valor de máxima concentração foi encontrado em $565 \mathrm{mg} \mathrm{kg}^{-1}$ de solo, enquanto o de mínima foi de $328 \mathrm{mg} \mathrm{kg}^{-1}$ de solo. No segundo corte o comportamento foi linear nas doses 1587,6 e 3175,2 e quadrático nas doses 0 e $4762,8 \mathrm{e} \mathrm{mg} \mathrm{kg}^{-1}$ de solo, os valores de máxima foram obtidos em 1050 e 643 $\mathrm{mg} \mathrm{kg}^{-1}$ de solo, respectivamente (Figura 30). A dose $3175,2 \mathrm{mg} \mathrm{kg}^{-1}$ de solo, do segundo corte está representada na (Figura 31). 

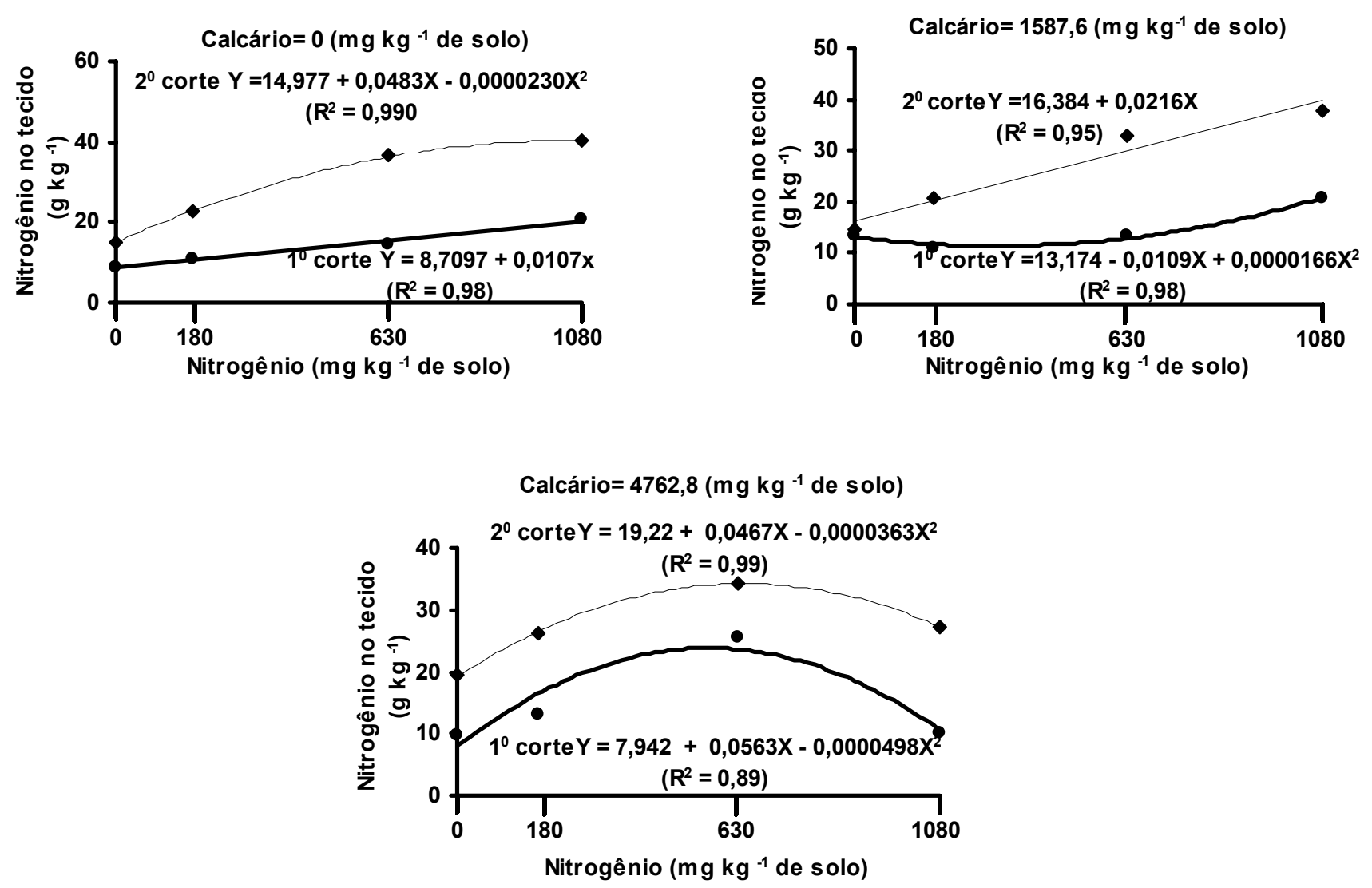

Figura 30 - Concentração de nitrogênio nas lâminas de folhas maduras da Brachiaria decumbens, no primeiro e segundo crescimentos em função das doses de nitrogênio dentro das doses 0,1587,6 e $4762,8 \mathrm{mg} \mathrm{kg}^{-1}$ de solo de calcário . 


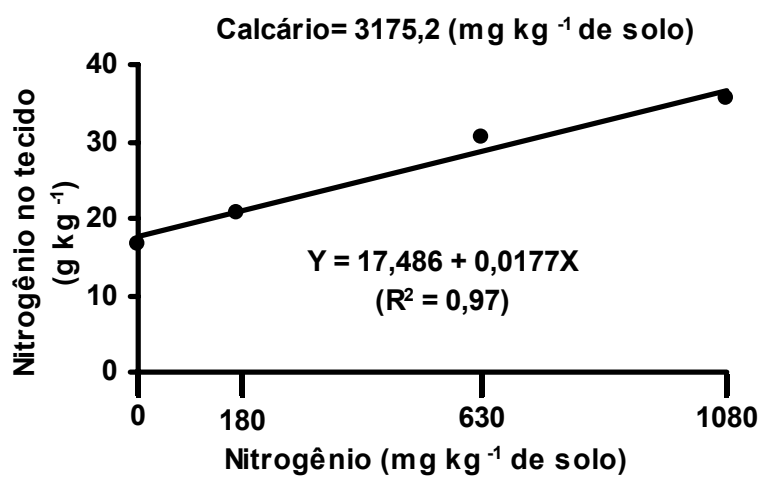

Figura 31 - Concentração de nitrogênio nas lâminas de folhas maduras da Brachiaria decumbens, no segundo crescimento em função das doses de nitrogênio dentro da dose de calcário $3175,2 \mathrm{mg} \mathrm{kg}^{-1}$ de solo.

No estudo das doses de calcário dentro das doses de nitrogênio, notouse efeito significativo $(P<0,05)$ das doses 630 e $1080 \mathrm{mg} \mathrm{kg}^{-1}$ de solo. Sendo que a dose de nitrogênio de $630 \mathrm{mg} \mathrm{kg}^{-1}$ de solo foi significativa apenas no primeiro corte (Figura 32) e teve seus efeitos representados por um modelo quadrático cujo o ponto de mínima foi de $1300 \mathrm{mg} \mathrm{kg}^{-1}$ de solo, para as doses de calcário dentro da referida dose de nitrogênio. Enquanto a dose $1080 \mathrm{mg}$ $\mathrm{kg}^{-1}$ de solo foi significativa $(P<0,05)$ nas duas avaliações (Figura 33). Os resultados ajustaram-se a um modelo linear nos dois casos. 


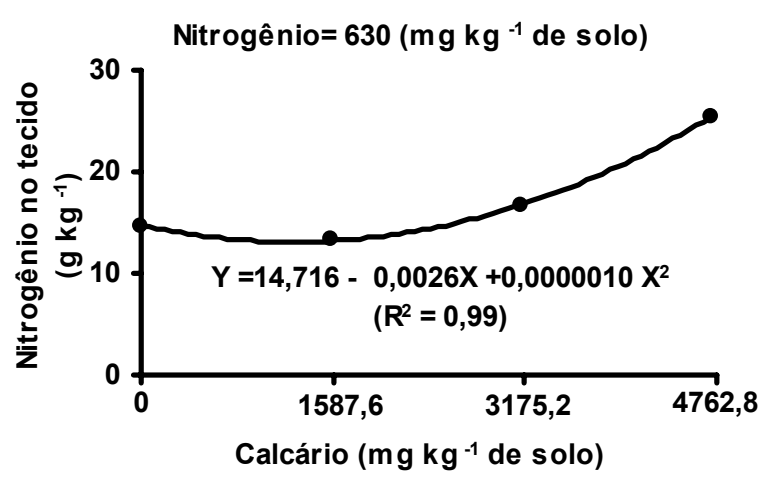

Figura 32 - Concentração de nitrogênio nas lâminas de folhas maduras da Brachiaria decumbens, no primeiro crescimento em função das doses de calcário dentro da dose $630 \mathrm{mg} \mathrm{kg}^{-1}$ de solo de nitrogênio.

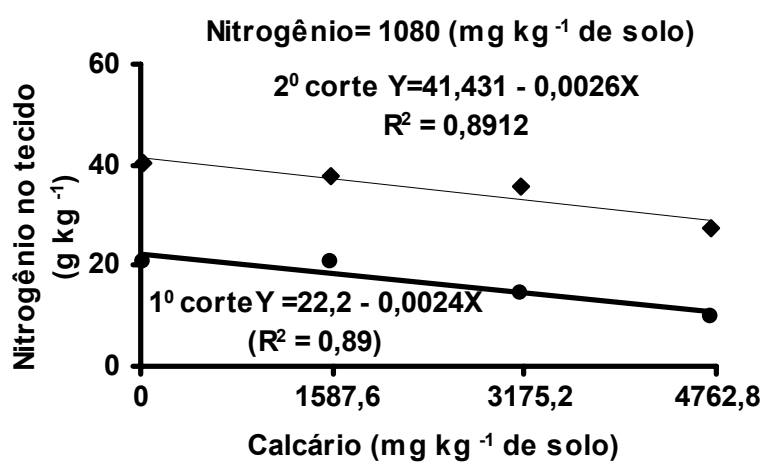

Figura 33 - Concentração de nitrogênio nas lâminas de folhas maduras da Brachiaria decumbens, nos dois cortes em função das doses de calcário dentro da dose de nitrogênio de $1080 \mathrm{mg} \mathrm{kg}^{-1}$ de solo.

Neste componente os teores de nitrogênio variaram de 7,94 a 38,31 g $\mathrm{kg}^{-1}$ no tecido vegetal. Santos (1997), encontrou comportamento linear para as doses de nitrogênio sobre este componente e o maior valor de concentração foi de $20,1 \mathrm{~g} \mathrm{~kg}^{-1}$. 
Nos colmos mais bainhas verificou-se efeito significativo $(P<0,05)$ para as doses de enxofre na primeira avaliação, doses de nitrogênio e interação nitrogênio e calcário na primeira e segunda avaliação.

As doses de enxofre sobre a concentração de nitrogênio no tecido tiveram ajustes a um modelo quadrático de regressão com o ponto de mínima alcançado em $66 \mathrm{mg} \mathrm{kg}^{-1}$ de solo (Figura 34). As doses de nitrogênio, no primeiro e segundo corte, também tiveram ajustes a um modelo quadrático, sendo que os valores de máxima foram obtidos em 919 e $975 \mathrm{mg} \mathrm{kg}^{-1}$ de solo de nitrogênio (Figura 35). Os teores de nitrogênio neste tecido vegetal variaram de 6,82 a $23,71 \mathrm{~g} \mathrm{~kg}^{-1}$ de matéria seca, em função das doses de nitrogênio.

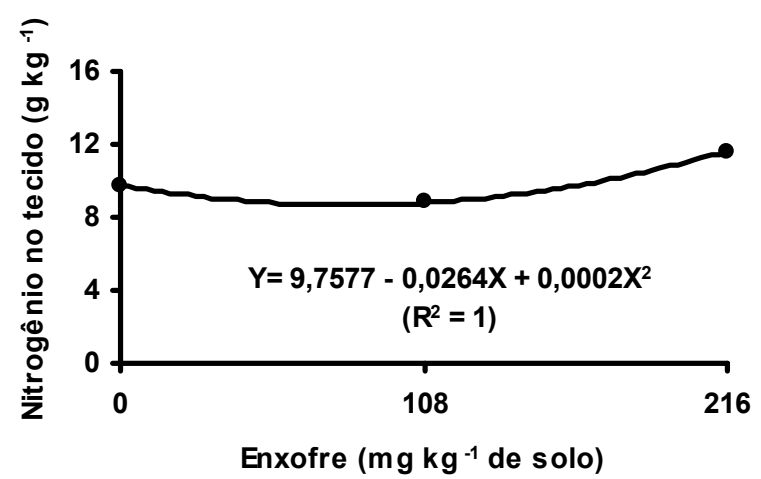

Figura 34 - Concentração de nitrogênio nos colmos mais bainhas da Brachiaria decumbens, no primeiro crescimento em função das doses de enxofre. 


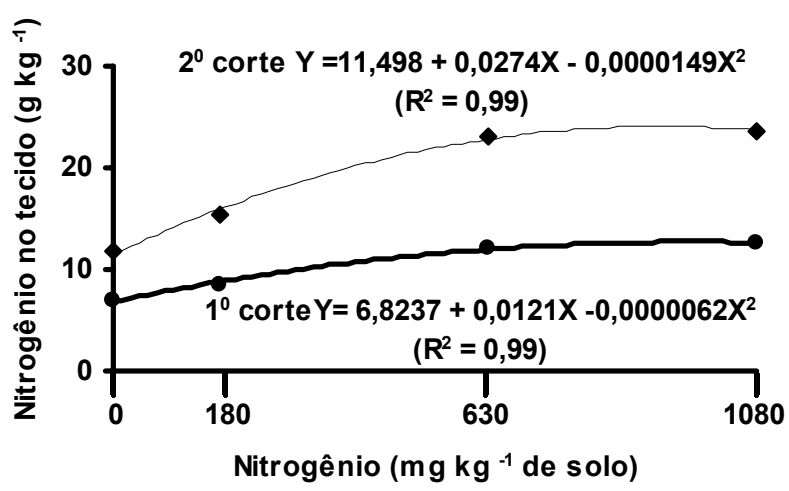

Figura 35 - Concentração de nitrogênio nos colmos mais bainhas da Brachiaria decumbens, no primeiro crescimento em função das doses de nitrogênio.

O estudo das doses de nitrogênio dentro das doses de calcário revelou significância $(P<0,05)$ para todas as doses de calcário, no primeiro e segundo cortes. Os resultados tiveram ajustes a um modelo linear nas doses de calcário 0; 1587,6 e 3175,2 $\mathrm{mg} \mathrm{kg}^{-1}$ de solo e a um modelo quadrático na dose 4762,8, no primeiro e segundo cortes. Observou-se que o ponto de máxima foi atingido em 577 e $982 \mathrm{mg} \mathrm{kg}^{-1}$ de solo, no primeiro e segundo cortes, respectivamente (Figura36). 

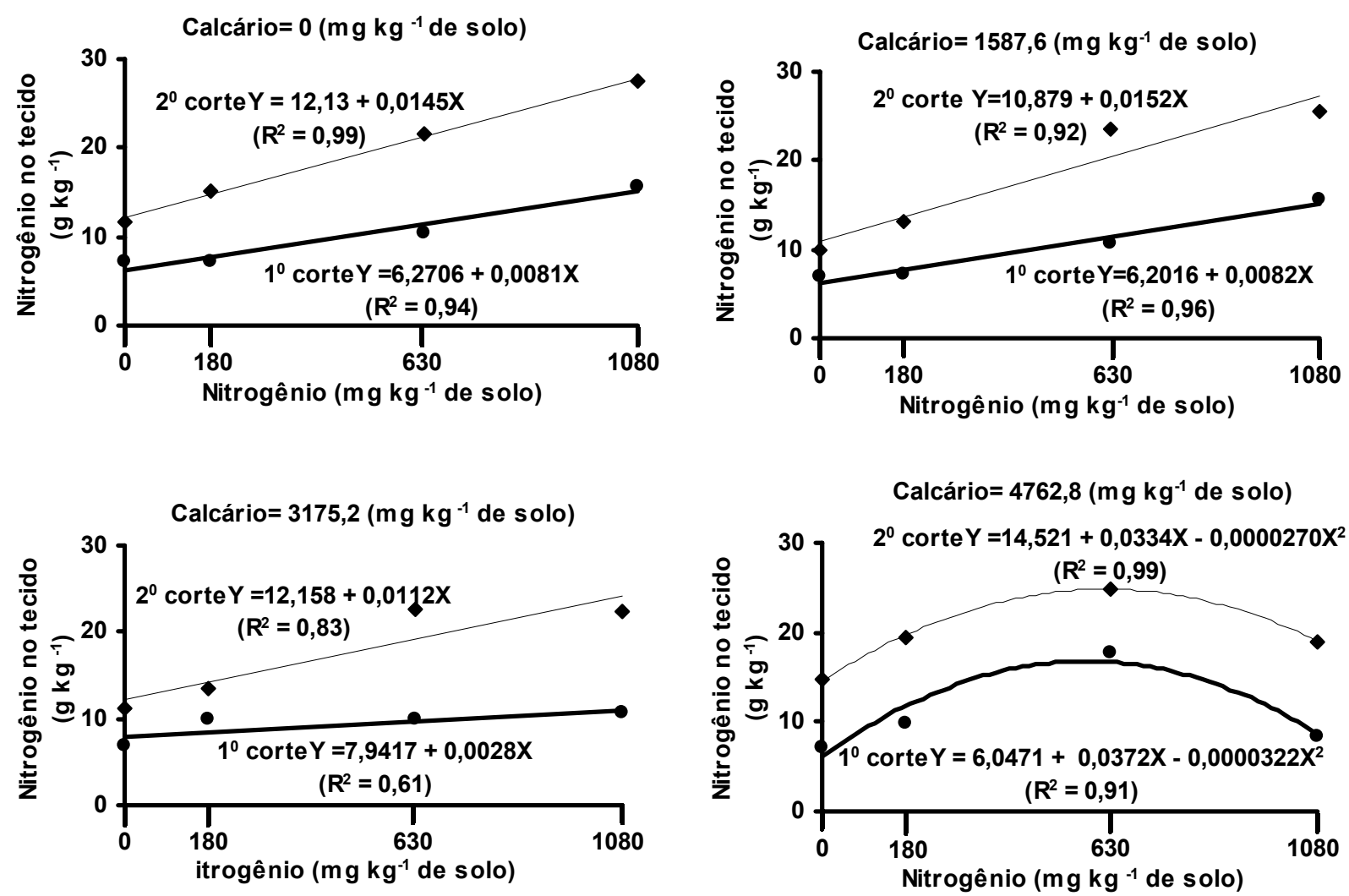

Figura 36 - Concentração de nitrogênio nos colmos mais bainhas da Brachiaria decumbens, no primeiro e segundo crescimentos em função das doses de nitrogênio dentro de cada dose de calcário.

Para as doses de calcário dentro das doses de nitrogênio notou-se efeito $(P<0,05)$ para as doses 180 e $1080 \mathrm{mg} \mathrm{kg}^{-1}$ de solo, nas duas avaliações (Figura 37) e, apenas para a dose $630 \mathrm{mg} \mathrm{kg}^{-1}$ de solo, no primeiro corte (Figura 38). Os resultados se ajustaram a um modelo linear nas doses $180 \mathrm{e}$ $1080 \mathrm{e}$, a um modelo quadrático na dose $630 \mathrm{mg} \mathrm{kg}^{-1}$ de solo do primeiro corte, com ponto de mínima obtido na dose de calcário de $1642,8 \mathrm{mg} \mathrm{kg}^{-1}$ de solo. No segundo corte, o comportamento foi linear na dose $1080 \mathrm{mg} \mathrm{kg}^{-1}$ de solo e quadrático na dose $180 \mathrm{mg} \mathrm{kg}^{-1}$ de solo. $\mathrm{O}$ ponto de mínima foi obtido em $2071,4 \mathrm{mg} \mathrm{kg}^{-1}$ de solo. 

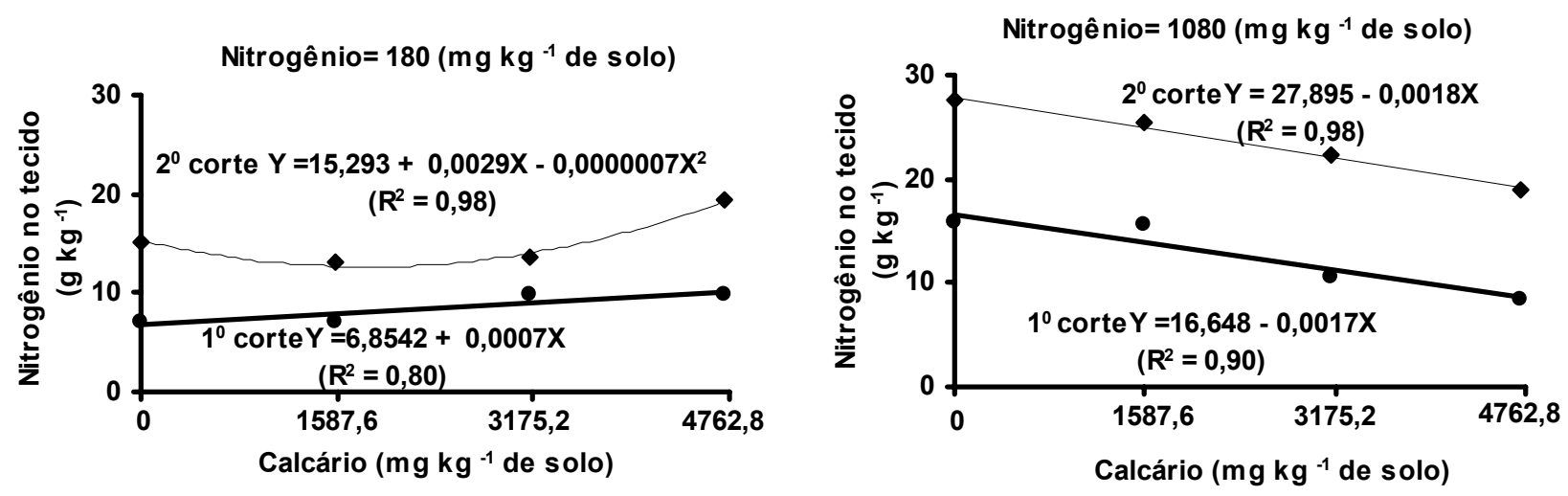

Figura 37 - Concentração de nitrogênio nos colmos mais bainhas da Brachiaria decumbens, no primeiro e segundo crescimentos em função das doses de calcário dentro das doses de nitrogênio 180 e $1080 \mathrm{mg}$ $\mathrm{kg}^{-1}$ de solo.

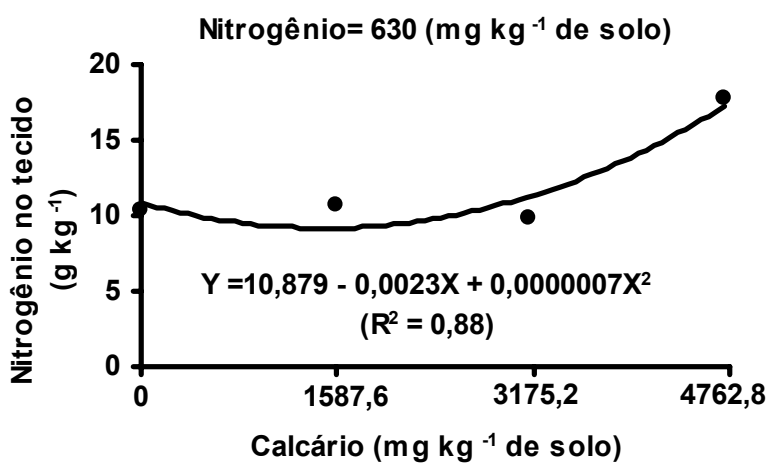

Figura 38 - Concentração de nitrogênio nos colmos mais bainhas da Brachiaria decumbens, no primeiro crescimento em função das doses de calcário dentro da dose de nitrogênio de $630 \mathrm{mg} \mathrm{kg}^{-1}$ de solo.

O comportamento das doses de nitrogênio dentro das doses de calcário tiveram comportamento linear na maioria dos casos, com exceção da dose de nitrogênio $1080 \mathrm{mg} \mathrm{kg}^{-1}$ de solo. Isso demonstra que a concentração de nitrogênio poderia ainda ser maior quando empregadas doses maiores de nitrogênio e calcário para esse capim. Na doses de calcário dentro das doses 
de nitrogênio $1080 \mathrm{mg} \mathrm{kg}^{-1}$ de solo, o comportamento foi linear decrescente. A variação na concentração de nitrogênio nesta fração foi de 6,04 a 27,29 em função da combinação de doses de nitrogênio e calcário. Observou-se que, este foi o componente da planta que apresentou a mais baixa concentração de nitrogênio no tecido. Este comportamento também foi observado por Santos (1997) e Premazzi ( 2001), que avaliaram doses de nitrogênio para os capins braquiária e tifton, respectivamente.

Os resultados demonstram que a concentração de nitrogênio pode ser mais elevada quando se utilizam maiores doses de calcário e nitrogênio, como ocorreu nas doses mais elevadas empregadas nesse estudo. Isso evidencia mais uma vez a importância do nitrogênio e da calagem para essa forrageira, uma vez que além de diminuir o $\mathrm{pH}$ favorecendo o desenvolvimento da planta, o fornecimento de $\mathrm{Ca}$ e $\mathrm{Mg}$ permite que a planta tenha uma melhor eficiência de utilização dos nutrientes.

\subsubsection{Fósforo}

$\mathrm{Na}$ análise de variância da concentração de fósforo nos componentes da parte aérea da braquiária, na primeira avaliação, foi constatado efeito significativo $(P<0,05)$ para as doses de nitrogênio em todos os componentes. $\mathrm{Na}$ segunda avaliação houve significância $(P<0,05)$ apenas para as doses de nitrogênio sobre a concentração de fósforo no tecido dos colmos mais bainhas

Avaliando os efeitos das doses de nitrogênio na concentração de fósforo nos componentes da parte aérea, notou-se um comportamento linear nas folhas emergentes (Figura 39), lâminas de folhas recém expandidas (Figura 40), lâminas de folhas maduras (Figura 41) e colmos mais bainhas (Figura 42). 


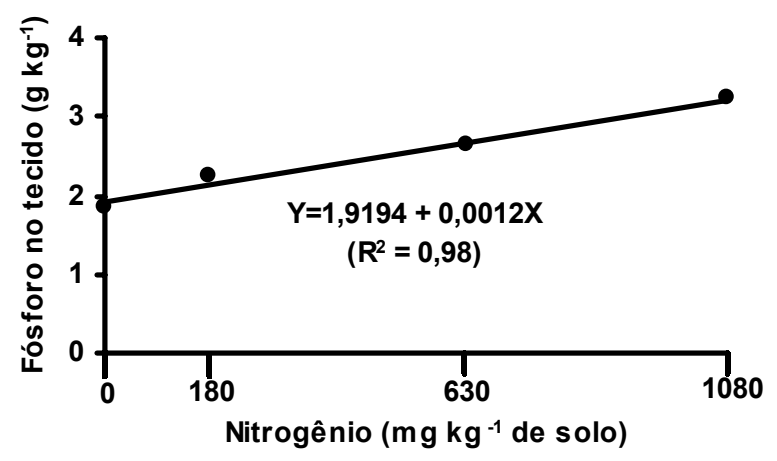

Figura 39 - Concentração de fósforo nas folhas emergentes da Brachiaria decumbens, no primeiro corte em função das doses de nitrogênio.

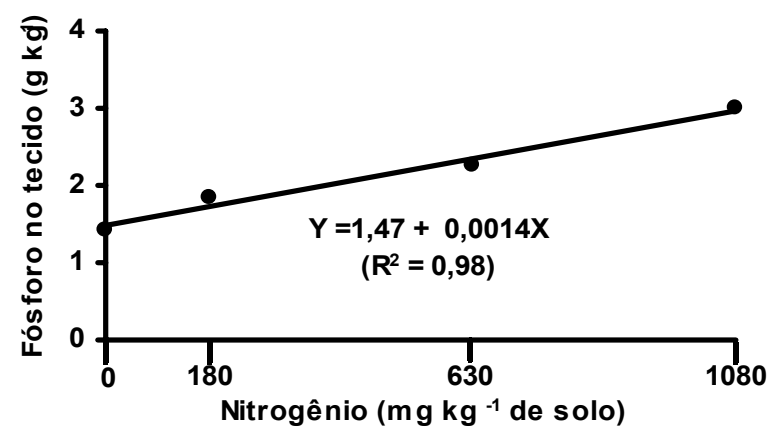

Figura 40 - Concentração de fósforo nas lâminas de folhas recém expandidas da Brachiaria decumbens, no primeiro corte em função das doses de nitrogênio.

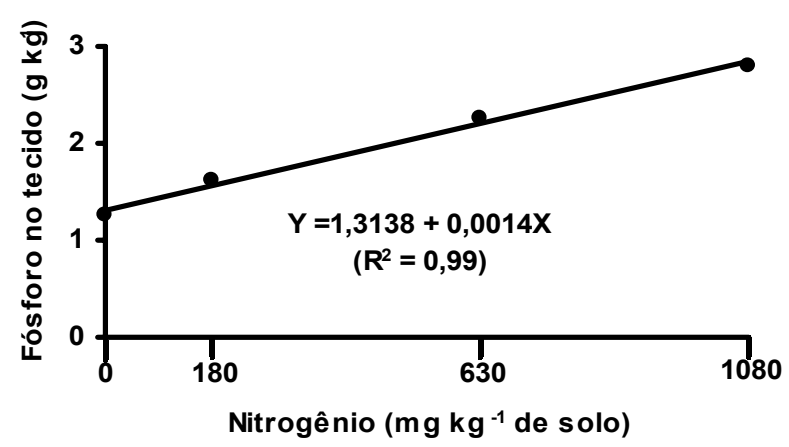

Figura 41 - Concentração de fósforo nas lâminas de folhas maduras da Brachiaria decumbens, no primeiro corte em função das doses de nitrogênio. 
No segundo crescimento, verificou-se significância $(P<0,05)$ para as doses de nitrogênio, apenas nos colmos mais bainhas da Brachiaria decumbens (Figura 42). Os efeitos das doses de nitrogênio na concentração de fósforo nos colmos mais bainhas, ajustou-se a um modelo linear.

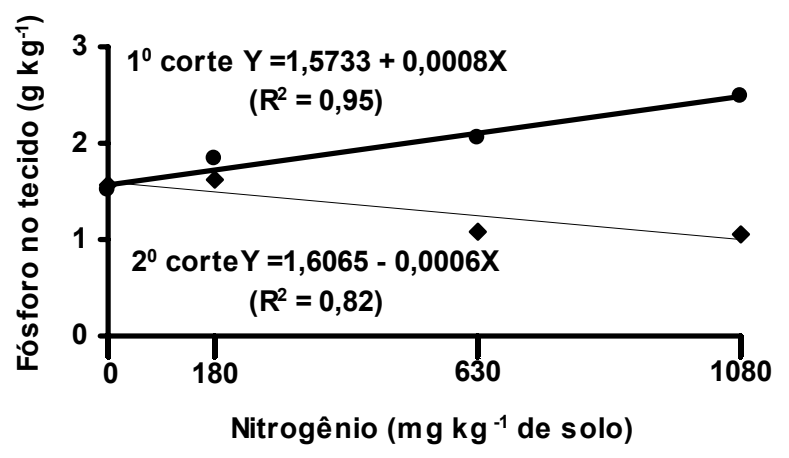

Figura 42 - Concentração de fósforo nos colmos mais bainhas da Brachiaria decumbens, no primeiro e segundo corte em função das doses de nitrogênio.

O comportamento linear das doses de nitrogênio sobre a concentração de fósforo nos componentes da parte aérea da braquiária, indica que as doses de nutrientes utilizadas nesse estudo não foram suficientes para que a máxima concentração do nutriente fosse atingida. $O$ fato de apenas os colmos mais bainhas terem sido significativos, no segundo corte pode ser explicado pela extração do fósforo no solo com o corte e pela maior produção de matéria seca, promovendo um efeito diluição. Os teores de fósforo neste tecido variaram de 0,95 a $3,21 \mathrm{~g} \mathrm{~kg}^{-1}$ na matéria seca. A maior concentração ocorreu nas folhas emergentes da planta.

Hernandez \& Cárdenas (1990) observaram que, o máximo teor de fósforo encontrado no capim-estrela (Cynodon nlemfluensis cv. Jamaicano) foi de $2,1 \mathrm{~g} \mathrm{~kg}^{-1}$ e $1,8 \mathrm{~g} \mathrm{~kg}^{-1}$, no primeiro e segundo ano, respectivamente, na dose mais baixa de nitrogênio ou quando este não foi suprido. Monteiro et al. (1995), em avaliações com Brachiaria brizantha Stapf cv. Marandu em solução nutritiva 
com omissões de macronutrientes, observaram teores de fósforo de $2,4 \mathrm{~g} \mathrm{~kg}^{-1}$ no tratamento completo. Ferragine (1998), encontrou que a concentração de fósforo nas lâminas de folhas novas do capim-braquiária, foi influenciada pelas dose de nitrogênio, nos dois cortes e os efeitos foram lineares.

\subsubsection{Potássio}

As doses de enxofre influenciaram significativamente $(P<0,05)$ a concentração de potássio nas folhas emergentes do capim-braquiária, no primeiro corte (Figura 43). Esse efeito foi representado por um modelo quadrático e o ponto de mínima ocorreu com a dose de enxofre de $180 \mathrm{mg} \mathrm{kg}^{-1}$ de solo.

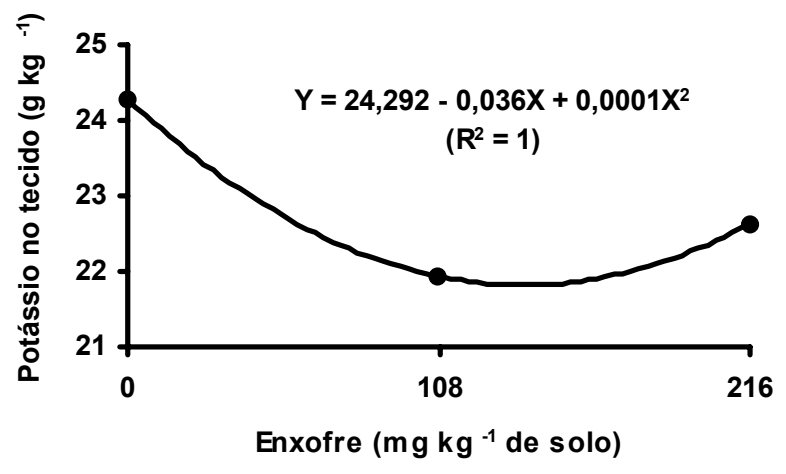

Figura 43 - Concentração de potássio nas lâminas das folhas emergentes da Brachiaria decumbens, no primeiro corte em função das doses de enxofre.

Por ocasião da segunda avaliação observou-se efeito significativo $(P<0,05)$ apenas das doses de nitrogênio sobre a concentração de potássio nesse componente. $O$ resultado teve ajuste a um modelo quadrático e o ponto de mínima ocorreu na dose $939 \mathrm{mg} \mathrm{kg}^{-1}$ de solo (Figura 44). A concentração de 
potássio no tecido foi de 21,18 a 24,29 em função das doses de enxofre e de 9,13 a $15,51 \mathrm{~g} \mathrm{~kg}^{-1}$ na matéria seca em função da adubação nitrogenada.

Nas lâminas de folhas recém expandidas da braquiária, no primeiro crescimento, foi observado significância $(\mathrm{P}<0,05)$ para as doses de calcário e para as doses de nitrogênio, no segundo corte (Figuras 45 e 46). Os resultados foram representados por um modelo linear para as doses de calcário e ao modelo quadrático para as doses de nitrogênio e o ponto de mínima ocorreu em $876,6 \mathrm{mg} \mathrm{kg}^{-1}$ de solo. A concentração de potássio no tecido variou de18,36 a 21,70 para as doses de calcário e de 4,10 a $15,30 \mathrm{~g} \mathrm{~kg}^{-1}$ na matéria seca em função da adubação com nitrogênio.

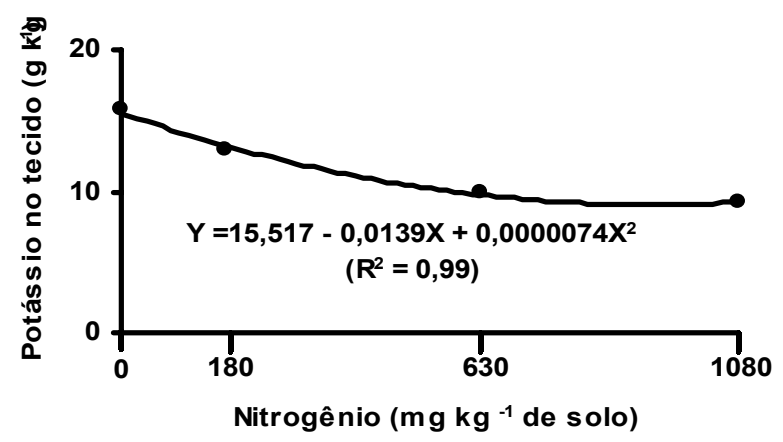

Figura 44 - Concentração de potássio nas lâminas das folhas emergentes da Brachiaria decumbens, no segundo corte em função das doses de nitrogênio. 


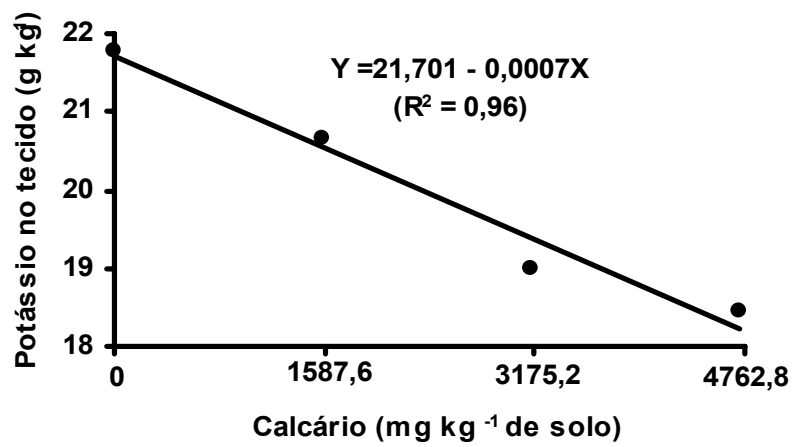

Figura 45 - Concentração de potássio nas lâminas de folhas recém expandidas da Brachiaria decumbens, no primeiro corte em função das doses de calcário.

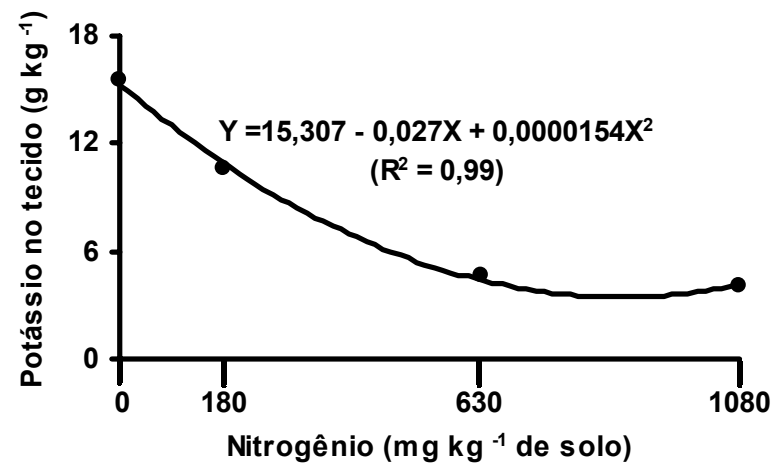

Figura 46 - Concentração de potássio nas lâminas de folhas recém-expandidas da Brachiaria decumbens, no primeiro corte em função das doses de nitrogênio.

Notou-se efeito significativo $(P<0,05)$ nas lâminas de folhas maduras para as doses de calcário no primeiro corte e para as doses de nitrogênio e interação nitrogênio e calcário no segundo corte. Os efeitos para as doses de calcário tiveram ajustes a um modelo linear de regressão (Figura 47). As doses de nitrogênio tiveram efeitos demonstrados por um modelo quadrático e o ponto de mínima encontrado em $823 \mathrm{mg} \mathrm{kg}^{-1}$ de solo (Figura 48). Os teores do 
nutriente no tecido foram de 18,14 a 21,00 e de 2,28 a $13,67 \mathrm{~g} \mathrm{~kg}^{-1}$ na matéria seca e, em função das doses de calcário e de nitrogênio, respectivamente.

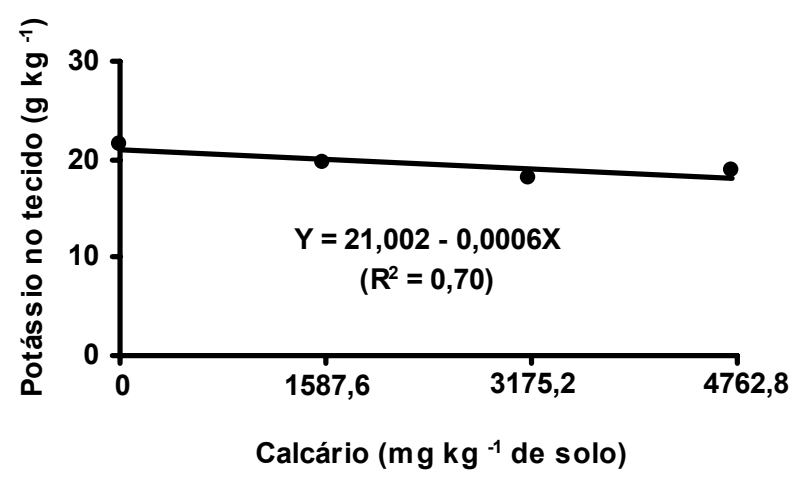

Figura 47 - Concentração de potássio nas lâminas de folhas maduras da Brachiaria decumbens, no primeiro corte em função das doses de calcário.

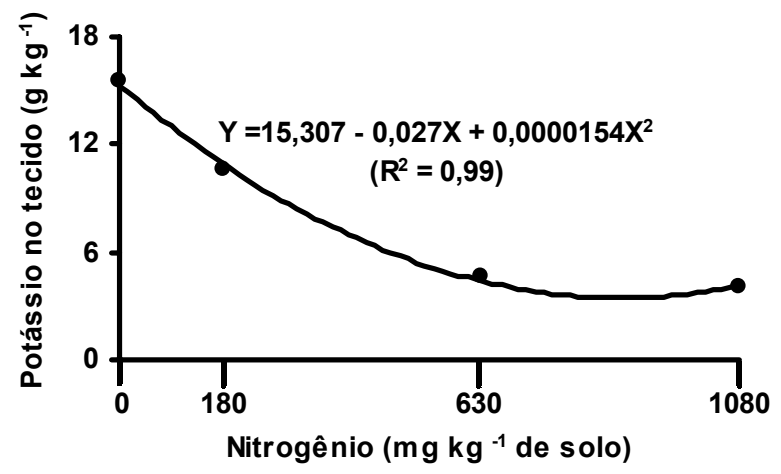

Figura 48 - Concentração de potássio nas lâminas de folhas maduras da Brachiaria decumbens, no segundo corte em função das doses de nitrogênio.

O estudo das doses de nitrogênio dentro das doses de calcário revelou efeito significativo $(\mathrm{P}<0,05)$ para todas as doses de calcário. Os resultados tiveram ajustes a um modelo linear na dose 0 e a um modelo quadrático nas 
demais doses (Figura 49). Os pontos de mínima foram encontrados em 868,7, 1254,4 e $847,3 \mathrm{mg} \mathrm{kg}^{-1}$ de solo de nitrogênio dentro das doses de calcário 1587,6, 3175,2 e 4762,8 $\mathrm{mg} \mathrm{kg}^{-1}$, respectivamente. Já nas doses de calcário dentro das doses de nitrogênio, apenas a dose de nitrogênio $180 \mathrm{mg} \mathrm{kg}^{-1} \mathrm{de}$ solo foi significativa $(P<0,05)$. $O$ resultado foi representado por um modelo linear (Figura 50).
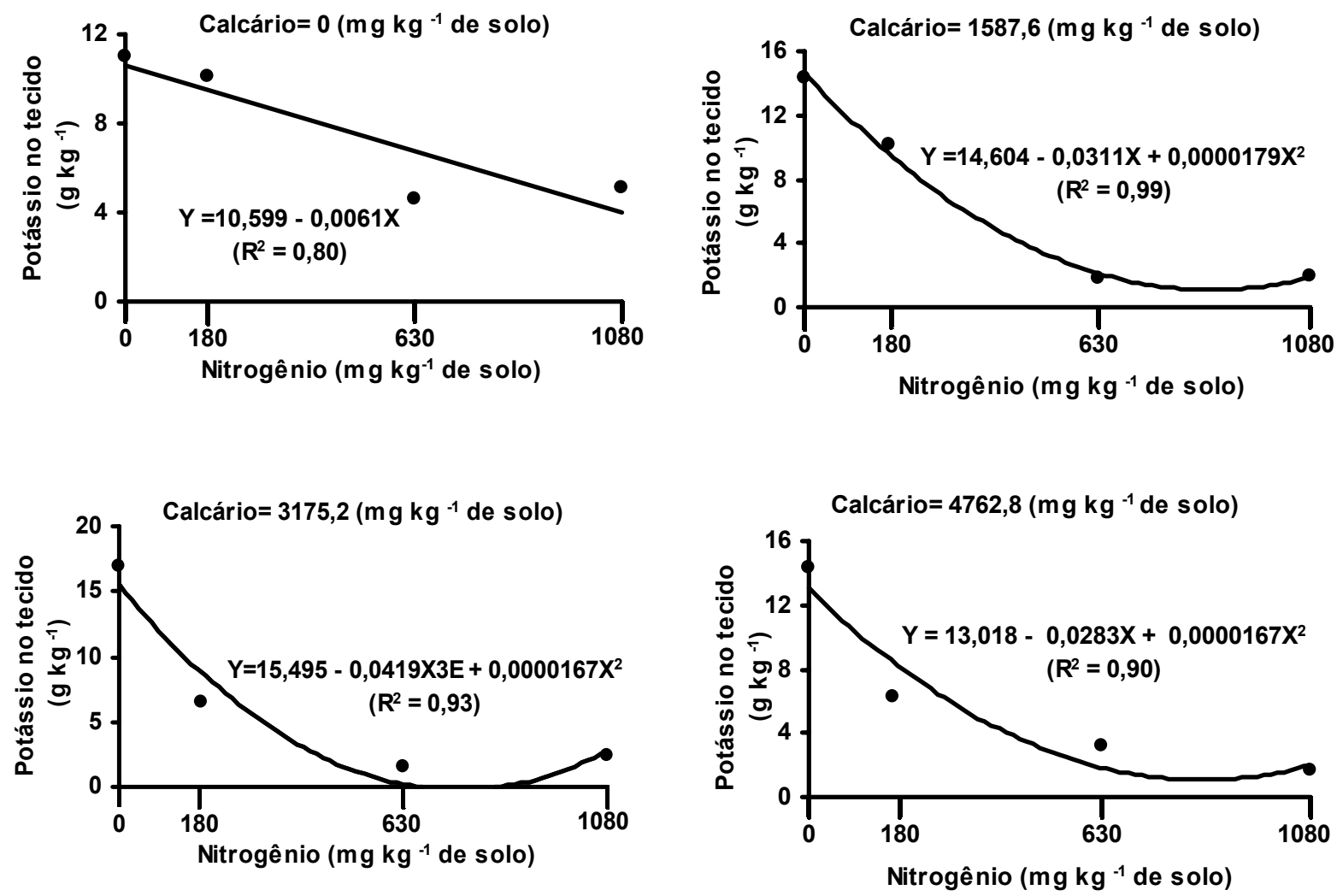

Figura 49 - Concentração de potássio nas lâminas de folhas maduras da Brachiaria decumbens, no segundo corte em função das doses de nitrogênio dentro de cada dose de calcário. 


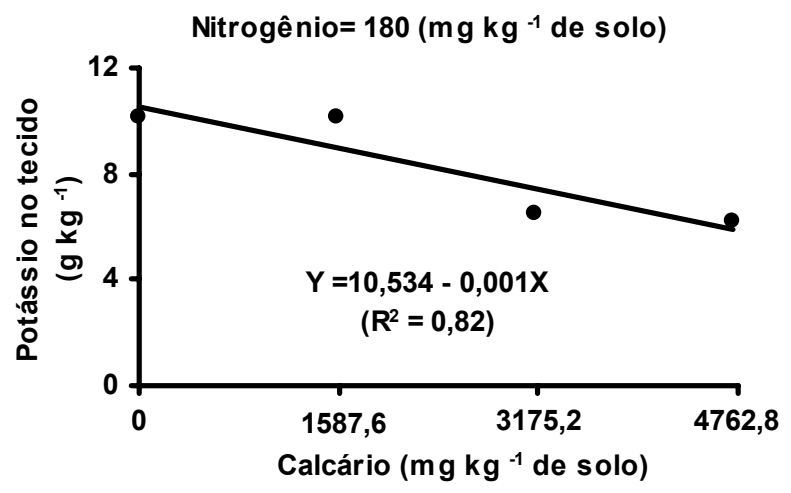

Figura 50 - Concentração de potássio nas lâminas de folhas maduras da Brachiaria decumbens, no segundo corte em função das doses de calcário dentro da dose de nitrogênio de $180 \mathrm{mg} \mathrm{kg}^{-1}$ de solo.

Houve interação significativa $(P<0,05)$ entre as doses de nitrogênio e calcário para a porção colmos mais bainhas da planta, no primeiro crescimento. Avaliando as doses de nitrogênio dentro das doses de calcário, verificou-se efeito significativo $(P<0,05)$ para as doses de calcário 0 e $3175,2 \mathrm{mg} \mathrm{kg}^{-1}$ de solo. Os resultados se ajustaram a um modelo linear na dose 0 e a um modelo quadrático, com ponto de mínima encontrado na dose de nitrogênio $603 \mathrm{mg} \mathrm{kg}^{-1}$ de solo dentro da respectiva dose de calcário (Figura 51). Na avaliação das doses de calcário dentro das doses de nitrogênio, verificou-se significância $(P<0,05)$ apenas para a dose de nitrogênio $630 \mathrm{mg} \mathrm{kg}^{-1}$ de solo. Esse efeito foi demonstrado por um modelo linear (Figura 52). Os teores de potássio nessa fração variaram de 23,58 a $29,26 \mathrm{~g} \mathrm{~kg}^{-1}$ na matéria seca em função da combinação das doses de nitrogênio e calcário. 

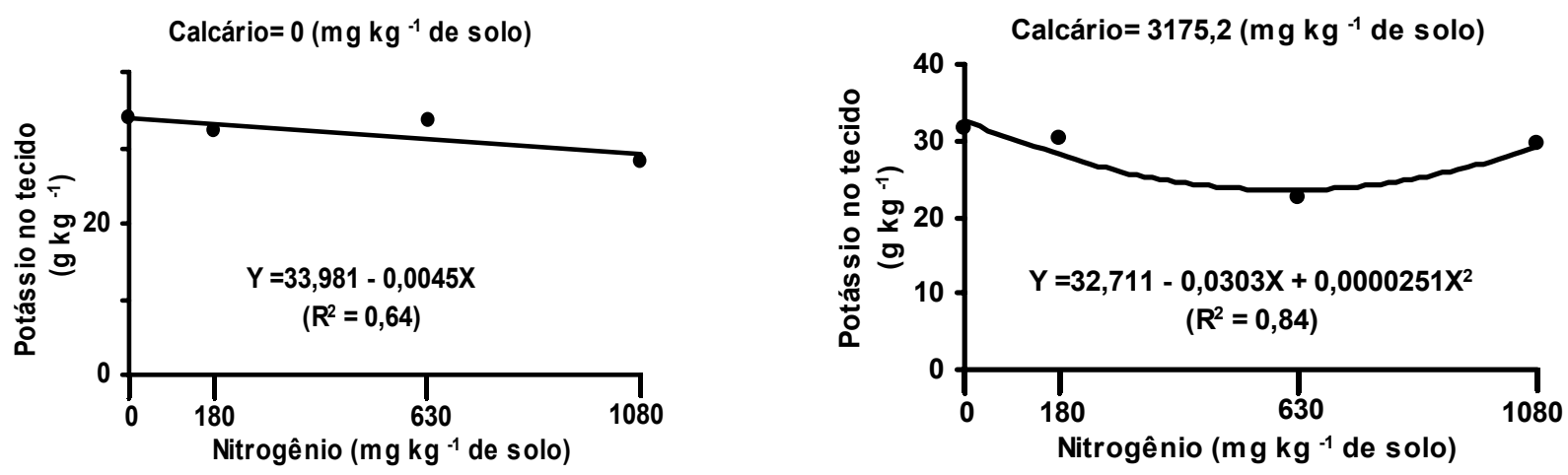

Figura 51 - Concentração de potássio nos colmos mais bainhas da Brachiaria decumbens, no primeiro corte em função das doses de nitrogênio dentro das doses de calcário 0 e $3175,2 \mathrm{mg} \mathrm{kg}^{-1}$ de solo.

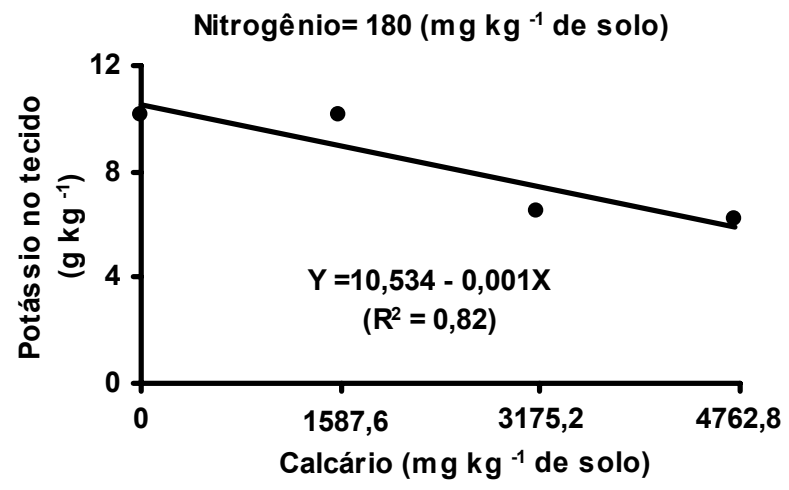

Figura 52 - Concentração de potássio nos colmos mais bainhas da Brachiaria decumbens, no primeiro corte em função das doses de calcário dentro da dose de nitrogênio $180 \mathrm{mg} \mathrm{kg}^{-1}$ de solo.

Por ocasião do segundo corte da forrageira, foi observado efeito significativo $(P<0,05)$ apenas para as doses de nitrogênio na concentração de potássio sobre esses componentes da planta. O resultado se ajustou a um modelo quadrático com ponto de mínima obtido em 1170,2 $\mathrm{mg} \mathrm{kg}^{-1}$ de solo de nitrogênio (Figura 53). 


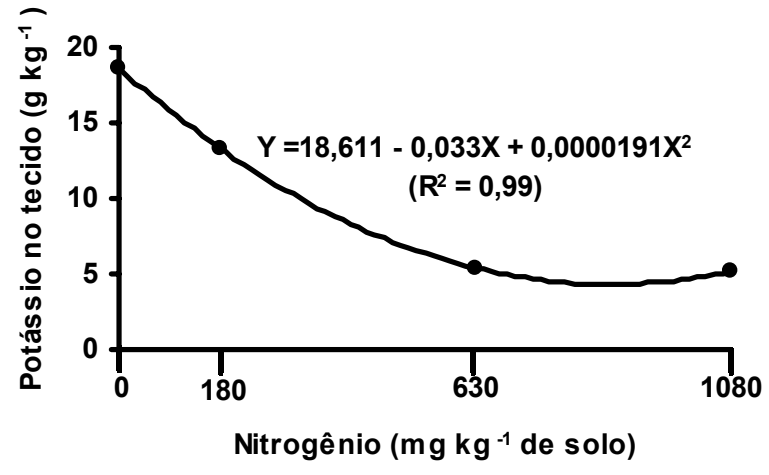

Figura 53 - Concentração de potássio nos colmos mais bainhas da Brachiaria decumbens, no segundo corte em função das doses de nitrogênio.

Pode-se observar efeito diluição, uma vez que nas menores doses de calcário, nitrogênio ou na interação entre ambos, houve uma maior concentração de potássio no tecido.

Resultados semelhantes foram obtidos por Fernandes et al. (1985), que encontraram uma redução no teor de potássio na parte aérea do capimbraquiária da ordem de 30 e $32 \%$, quando elevaram as doses de nitrogênio de 20 para $40 \mathrm{~kg} \mathrm{ha}^{-1}$ respectivamente, em relação à não aplicação de adubo nitrogenado. Ferragine (1998) trabalhando com Brachiaria decumbens também encontrou uma redução no teor de potássio quando se elevou as doses de nitrogênio na solução.

\subsubsection{Enxofre}

A concentração de enxofre no tecido das folhas emergentes da braquiária apresentou efeito significativo $(P>0,05)$ para as doses nitrogênio, no primeiro e segundo cortes. Os resultados tiveram ajustes a um modelo quadrático no primeiro corte, com o ponto de máxima obtido em $833 \mathrm{mg} \mathrm{kg}^{-1}$ de solo e a um modelo linear no segundo corte (Figura 54). Pode-se verificar que 
as concentrações de enxofre variaram de 0,85 a 2,15 $\mathrm{g} \mathrm{kg}^{-1}$ em função da adubação nitrogenada.

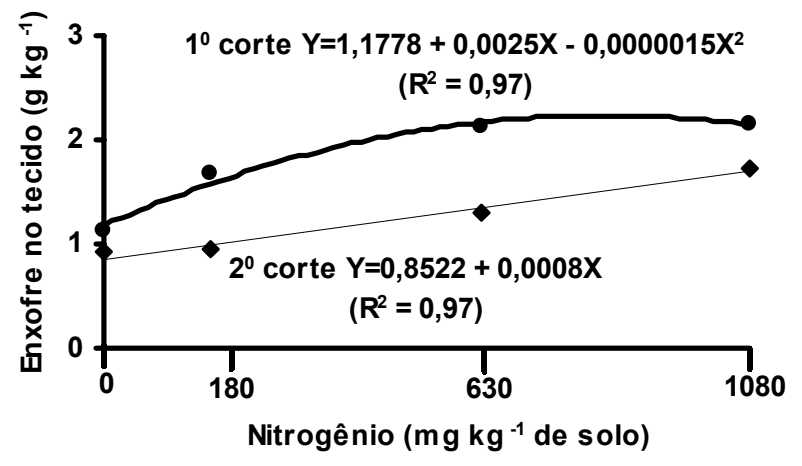

Figura 54 - Concentração de enxofre no tecido das folhas emergentes da Brachiaria decumbens, no primeiro e segundo corte em função das doses de nitrogênio.

Esse componente também sofreu efeito significativo $(P<0,05)$ das doses de enxofre no segundo corte, cujo efeito foi demonstrado por um modelo linear (Figura 55 ). O comportamento linear das doses de enxofre indica que a as doses desse nutriente utilizadas não foram suficientes para que a planta atingisse a máxima concentração. Os teores de enxofre variaram de 1,04 a 1,39 $\mathrm{g} \mathrm{kg}^{-1}$. 


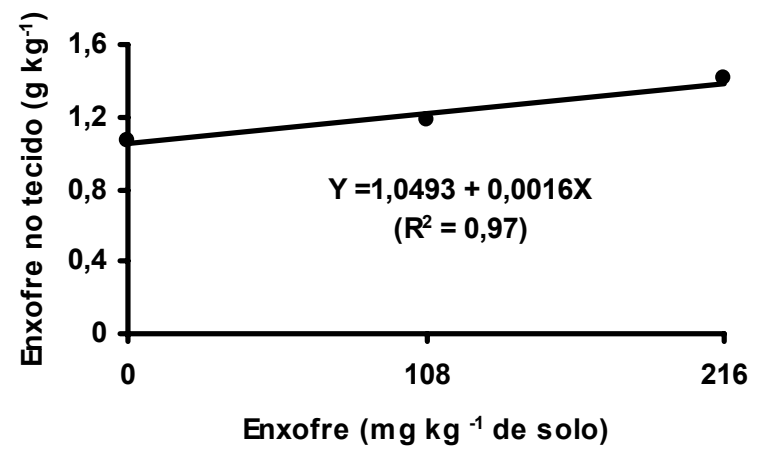

Figura 55 - Concentração de enxofre no tecido das folhas emergentes da Brachiaria decumbens, no segundo corte em função das doses de enxofre.

As lâminas de folhas recém-expandidas apresentaram efeito significativo $(P<0,05)$ para as doses de nitrogênio e calcário, no primeiro corte e para a interação entre as doses de enxofre e nitrogênio no segundo corte. As doses de nitrogênio tiveram efeitos representados por um modelo quadrático, com ponto de máxima obtido na dose $916,6 \mathrm{mg} \mathrm{kg}^{-1}$ de solo (Figura 56). A variação na concentração de enxofre em função das doses de nitrogênio foi de 1,28 a 2,27 $\mathrm{g} \mathrm{kg}^{-1}$ das mais baixas para as mais altas doses do nutriente. As doses de calcário seguiram um modelo linear de regressão (Figura 57). Os teores de enxofre foram decrescentes à medida que se elevou as doses de calcário e a variação foi de 1,66 a $2,01 \mathrm{~g} \mathrm{~kg}^{-1}$. 


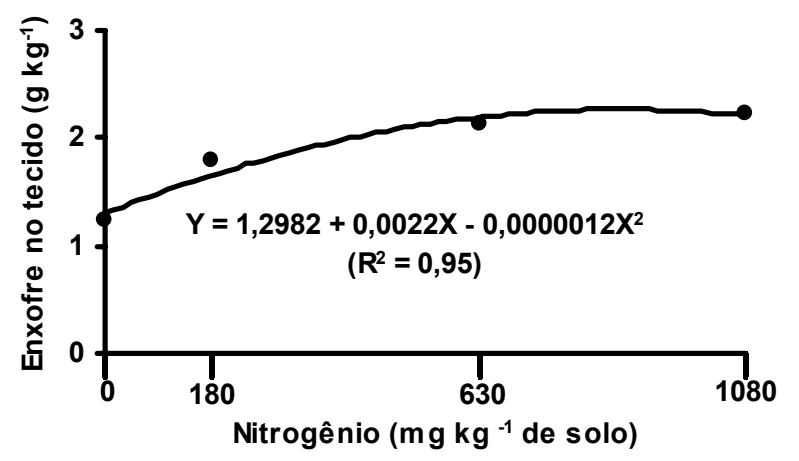

Figura 56 - Concentração de enxofre no tecido das folhas recém-expandidas da Brachiaria decumbens, no primeiro corte em função das doses de nitrogênio.

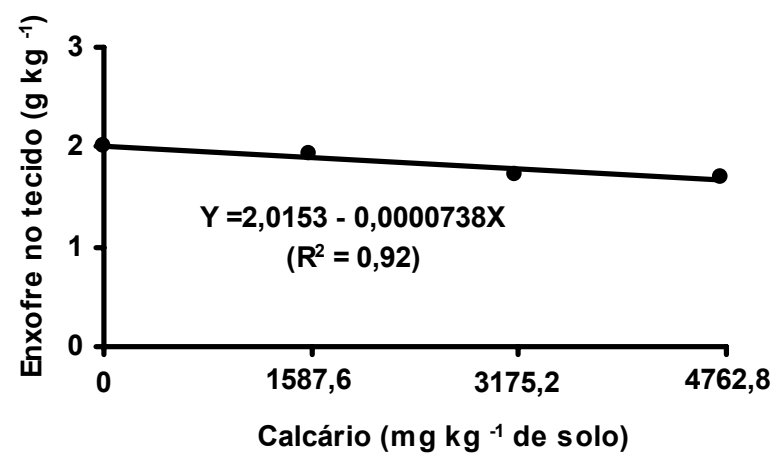

Figura 57 - Concentração de enxofre no tecido das lâminas de folhas recém expandidas da Brachiaria decumbens, no primeiro corte, em função das doses de calcário.

No estudo das doses de enxofre dentro das doses de nitrogênio, observou-se efeito significativo $(P<0,05)$ para as doses 0,630 e $1080 \mathrm{mg} \mathrm{kg}^{-1}$ de solo. Os resultados foram demonstrados por um modelo linear em todos os casos (Figura 58). A variação na concentração de enxofre no tecido em função das doses de enxofre dentro das doses de nitrogênio foi de 0,90 a 2,44 $\mathrm{g} \mathrm{kg}^{-1}$. Já o estudo das doses de nitrogênio dentro das doses de enxofre revelou efeito significativo $(P<0,05)$ para todas as doses de enxofre. Os resultados também 
seguiram um modelo linear em todos os casos (Figura 59). Os teores do nutriente no tecido para as doses nitrogênio dentro das doses de enxofre foram de 1,00 a 2,46 $\mathrm{g} \mathrm{kg}^{-1}$. Os resultados apontam que, concentrações maiores de enxofre poderão ser alcançadas com doses de enxofre e nitrogênio mais elevadas que as utilizadas neste estudo.
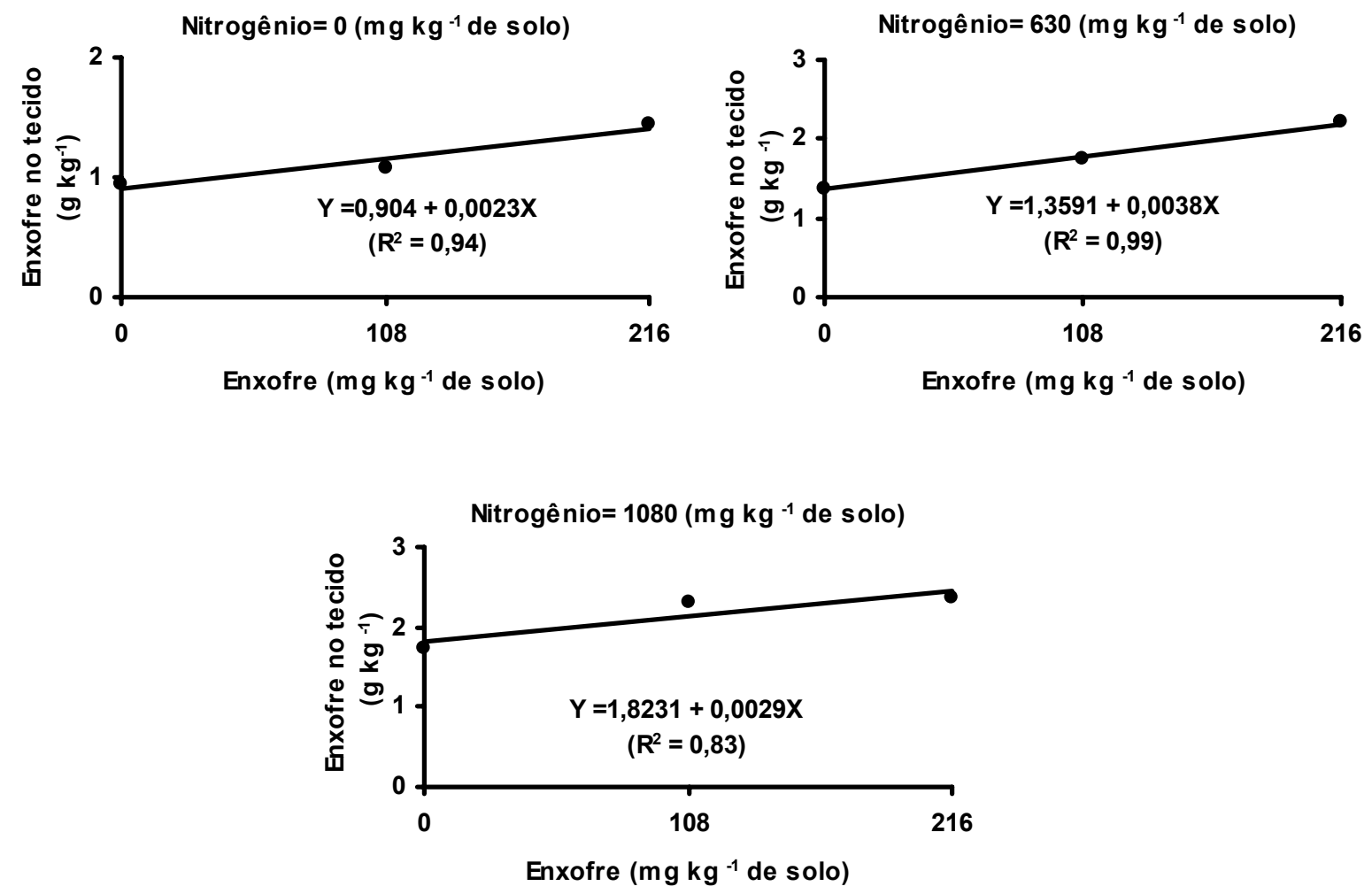

Figura 58 - Concentração de enxofre no tecido das lâminas de folhas recémexpandidas da Brachiaria decumbens, no segundo corte, em função das doses de enxofre dentro das doses de nitrogênio 0, 630 e 1080 $\mathrm{mg} \mathrm{kg}^{-1}$ de solo. 

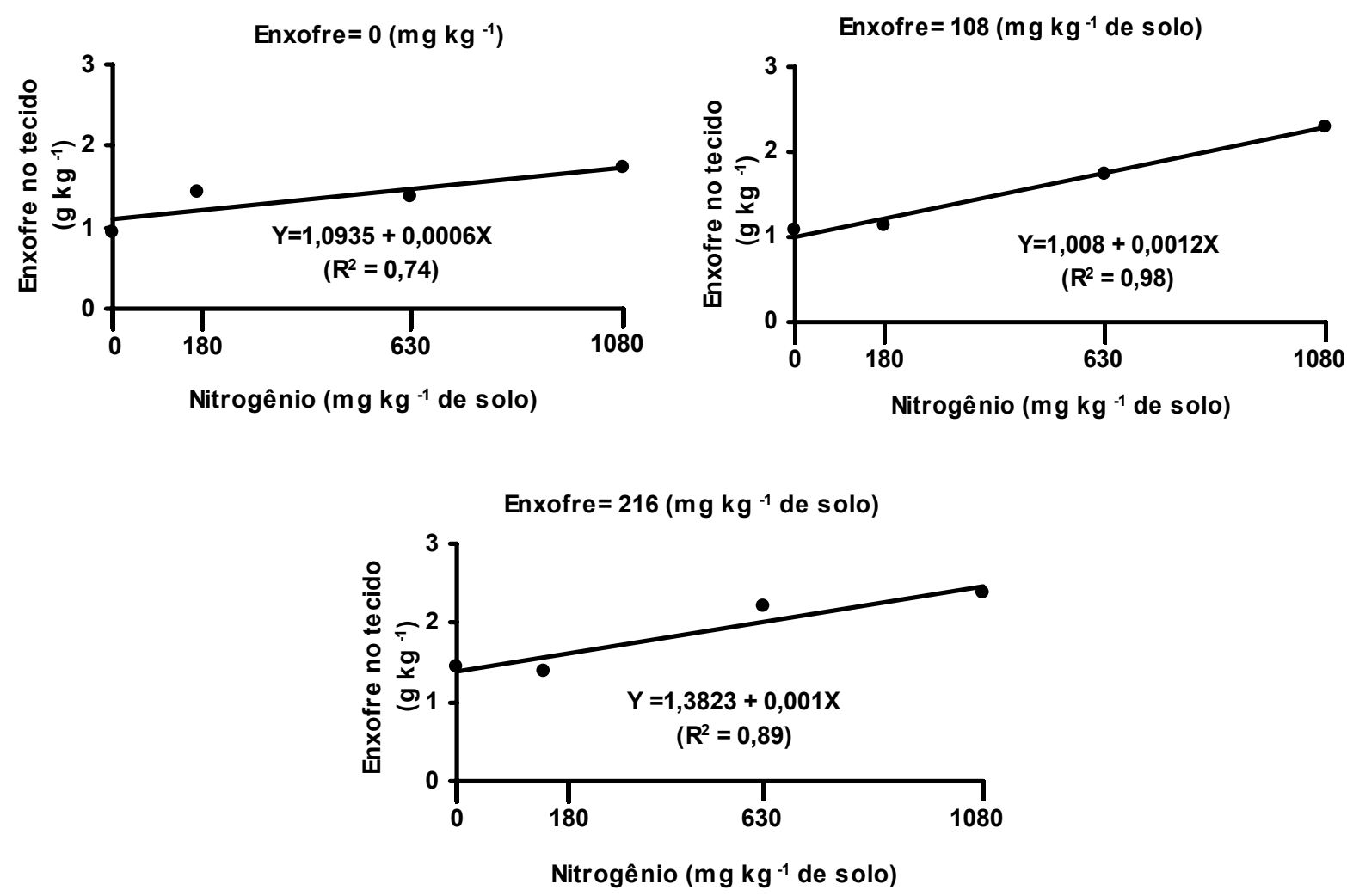

Figura 59 - Concentração de enxofre nas lâminas de folhas maduras da Brachiaria decumbens, no segundo corte, em função das doses de nitrogênio dentro de cada dose de enxofre.

Nas lâminas de folhas maduras houve efeito $(P<0,05)$ para as doses de enxofre, nitrogênio e calcário, no primeiro corte. No segundo, corte houve efeito $(P<0,05)$ apenas para as doses de enxofre e nitrogênio. As doses de enxofre tiveram um comportamento linear nas duas avaliações (Figura 60) e os teores no tecido foram de 1,79 a $3,27 \mathrm{~g} \mathrm{~kg}^{-1}$. Os efeitos das doses de nitrogênio seguiram um modelo quadrático de regressão nos dois cortes com pontos de máxima obtidos em 821,42 e $738,09 \mathrm{mg} \mathrm{kg}^{-1}$ de solo (Figura 61). A concentração de enxofre variou de 1,42 a $3,34 \mathrm{~g} \mathrm{~kg}^{-1}$. As doses de calcário tiveram um ajuste a um modelo linear (Figura 62). A concentração de enxofre 
em função das doses de calcário foram decrescentes e variou de 2,16 a 1,76 g $\mathrm{kg}^{-1}$.

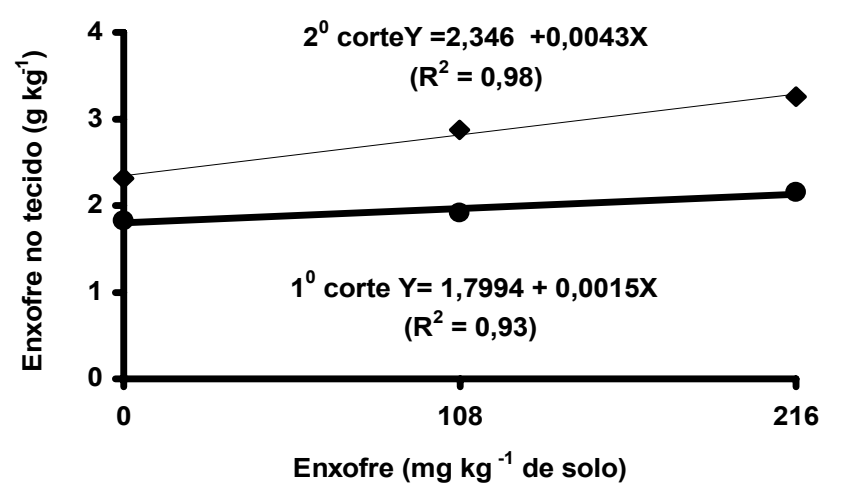

Figura 60 - Concentração de enxofre nas lâminas de folhas maduras da Brachiaria decumbens, no primeiro e segundo cortes, em função das doses de enxofre.

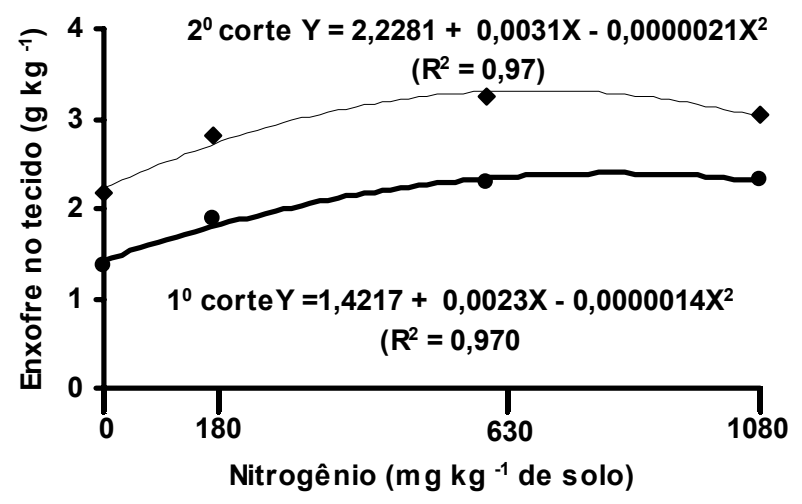

Figura 61 - Concentração de enxofre nas lâminas de folhas maduras da Brachiaria decumbens, no primeiro e segundo corte, em função das doses de nitrogênio. 


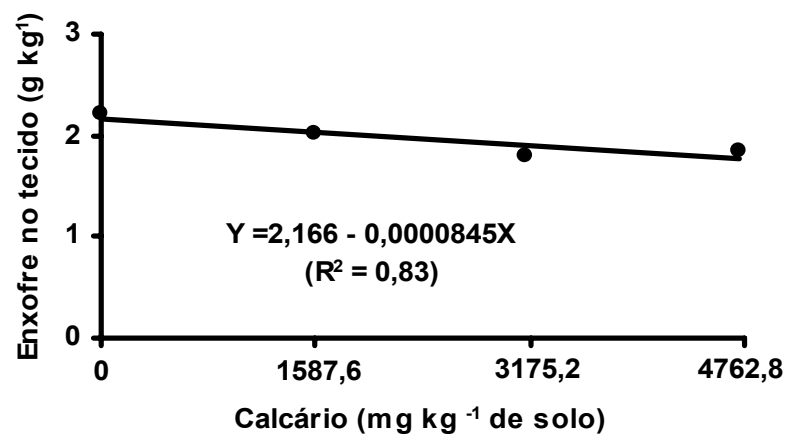

Figura 62 - Concentração de enxofre nas lâminas de folhas maduras da Brachiaria decumbens, no primeiro corte, em função das doses de calcário.

Os componentes colmos mais bainhas apresentaram efeitos significativos $(P<0,05)$ para as doses de enxofre, no primeiro e segundo cortes. Esses efeitos foram demonstrados por um modelo linear em ambos os casos (Figura 63) e, a variação desse nutriente no tecido em função da adubação com enxofre foi de 1,56 a $2,27 \mathrm{~g} \mathrm{~kg}^{-1}$.

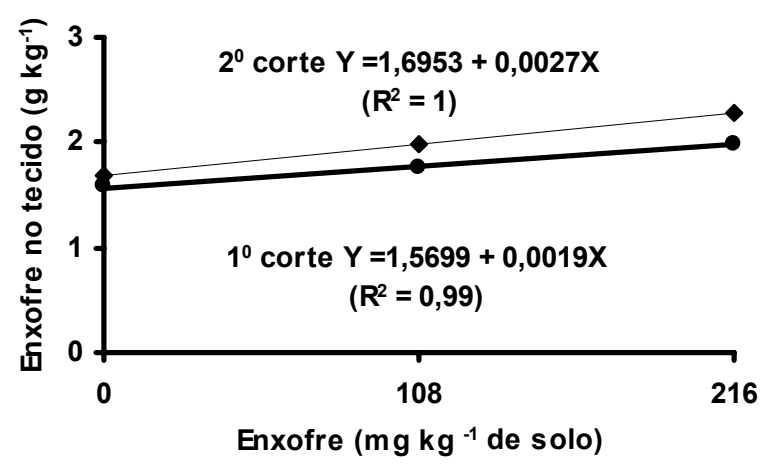

Figura 63 - Concentração de enxofre nos colmos mais bainhas da Brachiaria decumbens, no primeiro e segundo corte, em função das doses de enxofre.

No primeiro corte ainda, houve efeito $(P<0,05)$ da interação nitrogênio e calcário. Avaliando as doses de nitrogênio dentro das doses de calcário, notou- 
se efeito significativo $(P<0,05)$ para as doses $0,3175,2$ e $4762,8 \mathrm{mg} \mathrm{kg}^{-1}$ de solo. Em todos os casos os resultados ajustaram a um modelo quadrático de regressão e os valores de máxima concentração foram obtidos em 500, 833,33 e $733,33 \mathrm{mg} \mathrm{kg}^{-1}$ de solo (Figura 64 ). A variação nas concentrações foram de1,25 a 2,24 $\mathrm{g} \mathrm{kg}^{-1}$. Observou-se ainda que, as maiores concentrações ocorreram com o nitrogênio na ausência de calcário. Já nas doses de calcário dentro das doses de nitrogênio, apenas as doses 0 e $180 \mathrm{mg} \mathrm{kg}^{-1}$ de solo revelaram efeitos significativos $(P<0,05)$. Nos dois casos os resultados seguiram um modelo linear de regressão (Figura 65). Os efeitos para as doses de calcário dentro das doses de nitrogênio foram decrescentes e variaram de 2,29 a $1,22 \mathrm{~g} \mathrm{~kg}^{-1}$.
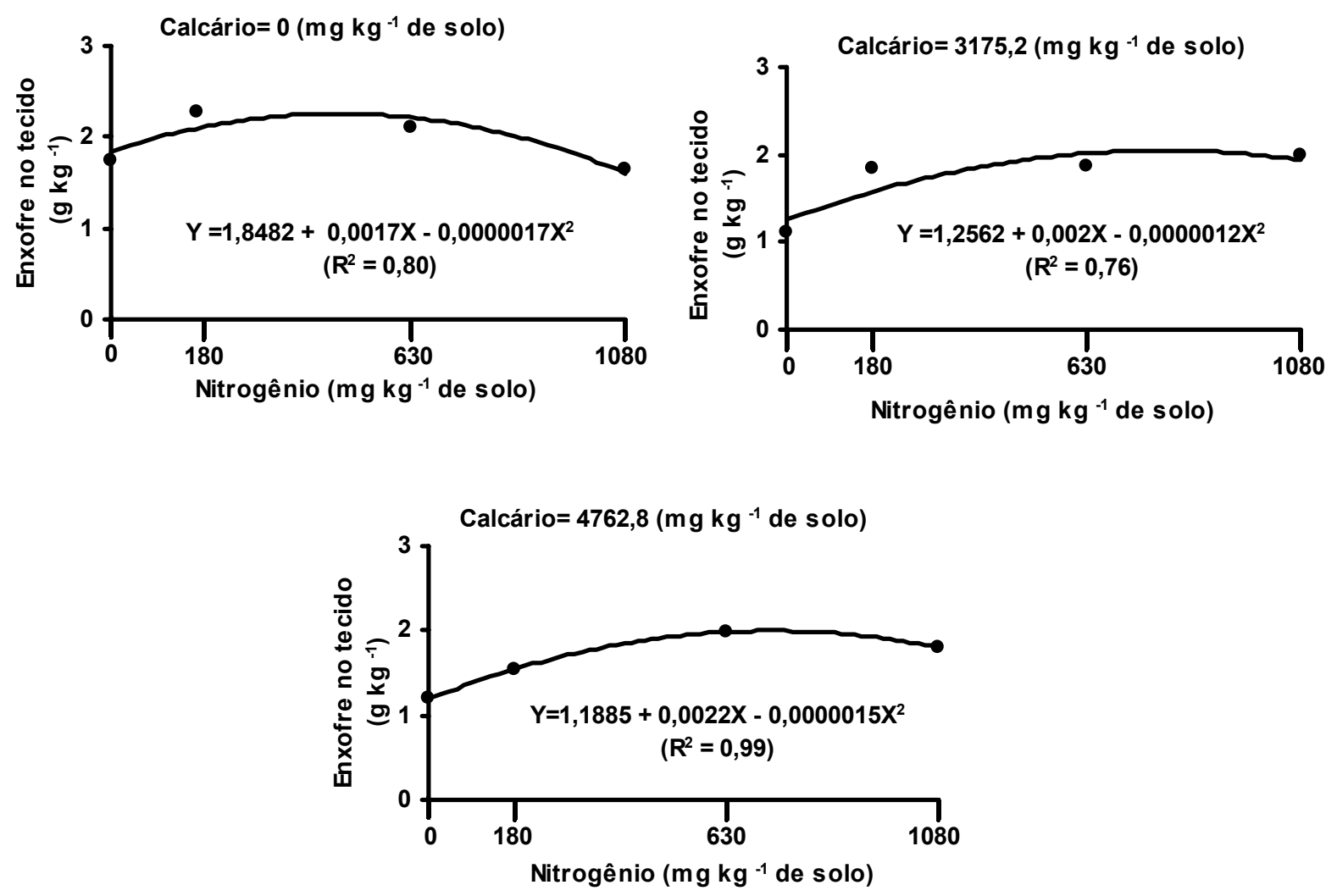

Figura 64 - Concentração de enxofre nos colmos mais bainhas da Brachiaria decumbens, no primeiro corte, em função das doses de nitrogênio dentro das respectivas doses de calcário. 

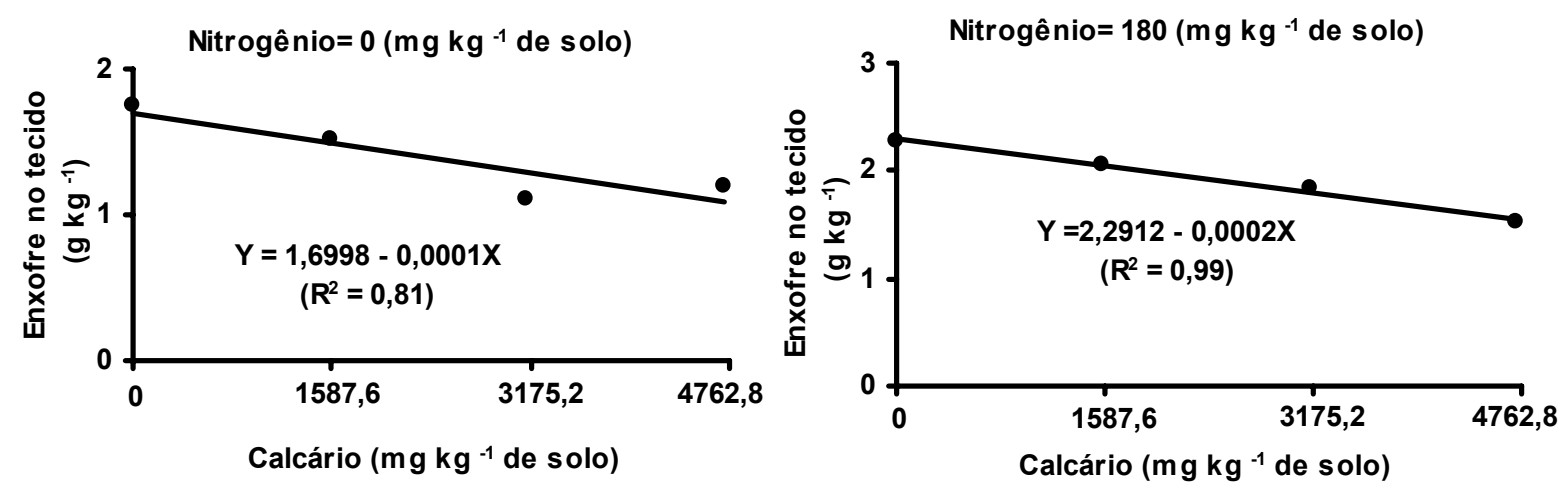

Figura 65 - Concentração de enxofre nos colmos mais bainhas da Brachiaria decumbens, no primeiro corte, em função das doses de calcário dentro das respectivas doses de nitrogênio.

Através da análise das equações de regressão constatou-se que, a máxima concentração de enxofre na parte aérea ocorreu nas lâminas de folhas maduras e nos colmos mais bainhas. Esse comportamento se deve à baixa mobilidade do nutriente na direção acrópeta da base da planta para cima. A dose de nitrogênio que proporcionou a maior concentração desse elemento na planta foi a dose $1080 \mathrm{mg} \mathrm{kg}^{-1}$ de solo.

Os valores de enxofre no tecido encontrados nesse estudo foram superiores aos encontrados por Monteiro et al. (1995) que, obtiveram na parte aérea da Brachiaria brizantha cv. Marandu, cultivada em solução nutritiva, teores de enxofre no tratamento completo de $2,4 \mathrm{~g} \mathrm{~kg}^{-1}$, enquanto que no tratamento com omissão desse nutriente o valor encontrado foi de $1,0 \mathrm{~g} \mathrm{~kg}^{-1}$. Faquin et al. (1995) avaliando doses de potássio e enxofre, encontraram nas lâminas de folhas novas do capim-braquiária teores de enxofre entre 0,9 e 1,2 g $\mathrm{kg}^{-1}$. Santos (1997) verificou que a máxima concentração de enxofre nas lâminas de folhas novas foi de $1,6 \mathrm{~g} \mathrm{~kg}^{-1}$. Mattos (2001) também observou que, a concentração de enxofre nas lâminas de folhas recém-expandida, variou em função das doses de nitrogênio dentro das doses 0 e $30 \mathrm{mg} \mathrm{dm}^{-3}$ e os resultados se ajustaram a modelos quadráticos. 


\subsubsection{Magnésio}

A análise de variância da concentração de magnésio nas folhas emergentes revelou significância $(P>0,05)$ para a interação entre as doses de nitrogênio e calcário, no primeiro corte. No segundo corte não houve efeito significativo $(P<0,05)$ para nenhum nutriente sobre esses componentes. No desdobramento da interação de nitrogênio dentro das doses de calcário, verificou-se efeito significativo $(P<0,05)$ para as doses de calcário 1587,6 , 3175,2 e $4762,8 \mathrm{mg} \mathrm{kg}^{-1}$ de solo (Figura 66 ). Os efeitos seguiram uma equação de segundo grau nas doses $1587,6,3175,2 \mathrm{mg} \mathrm{kg}^{-1}$ de solo, com pontos de máxima produção encontrados em 670 e $709 \mathrm{mg} \mathrm{kg}^{-1}$ de solo. $\mathrm{Na}$ dose de calcário de $4762,8 \mathrm{mg} \mathrm{kg}^{-1}$ de solo $\mathrm{o}$ ajuste foi linear. Os valores das concentrações de magnésio variaram de 1,27 a $4,84 \mathrm{~g} \mathrm{~kg}^{-1}$. Já no estudo das doses de calcário dentro das doses de nitrogênio, apenas as doses 180 e 1080 $\mathrm{mg} \mathrm{kg}^{-1}$ de solo apresentaram efeito significativo $(\mathrm{P}<0,05)$. Em ambos os casos os efeitos foram demonstrados por um modelo linear (Figura 67). Esses resultados indicam que, a concentração de magnésio nessa parte do capimbraquiária poderia ser mais elevada na utilização de doses de nitrogênio e calcário maiores que as empregadas neste estudo. 

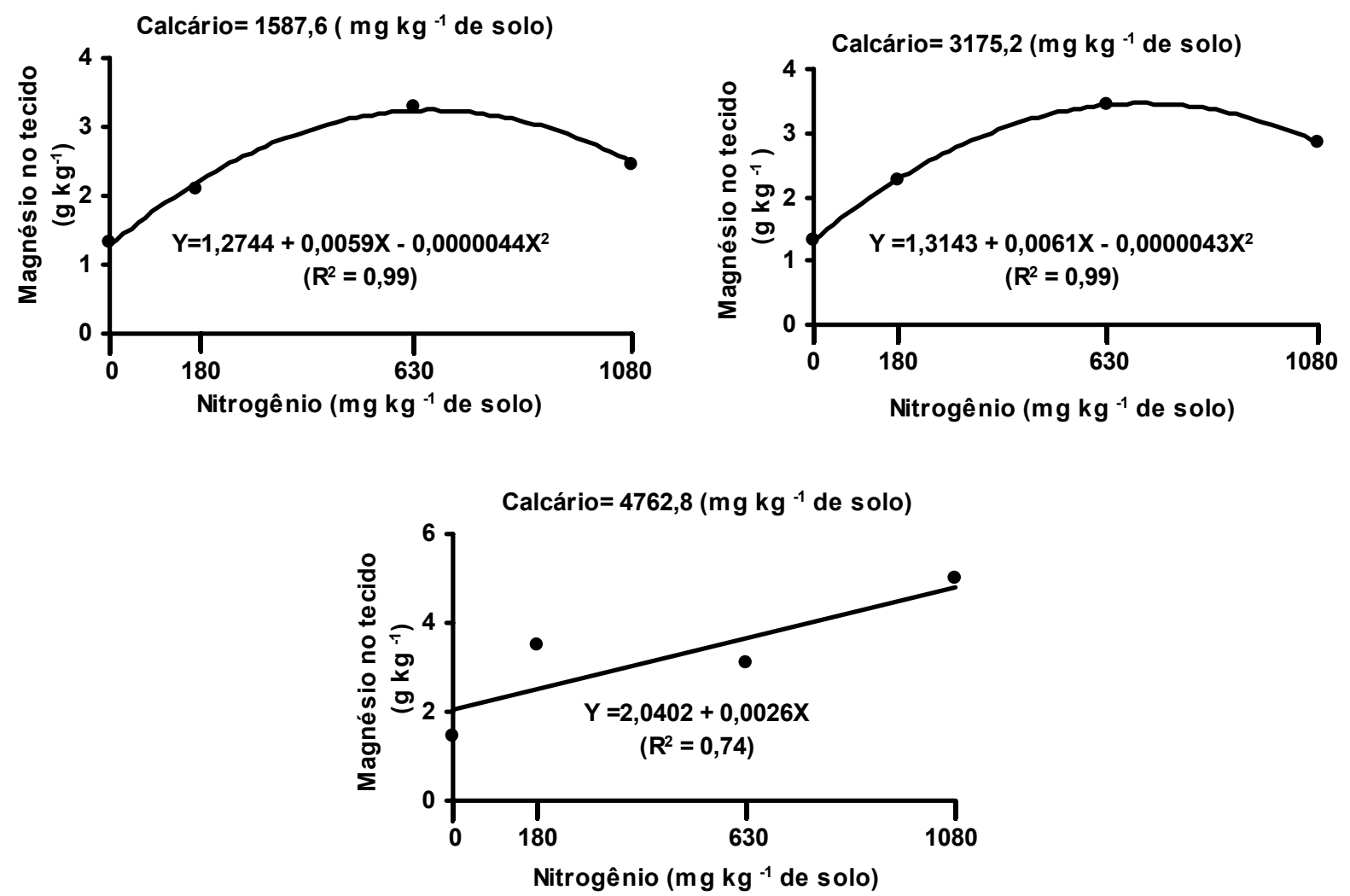

Figura 66 - Concentração de magnésio nas folhas emergentes da Brachiaria decumbens, no primeiro corte, em função das doses de nitrogênio dentro das doses de calcário 1587,6, 3175,2 e 4762,8 $\mathrm{mg} \mathrm{kg}^{-1}$ de solo.
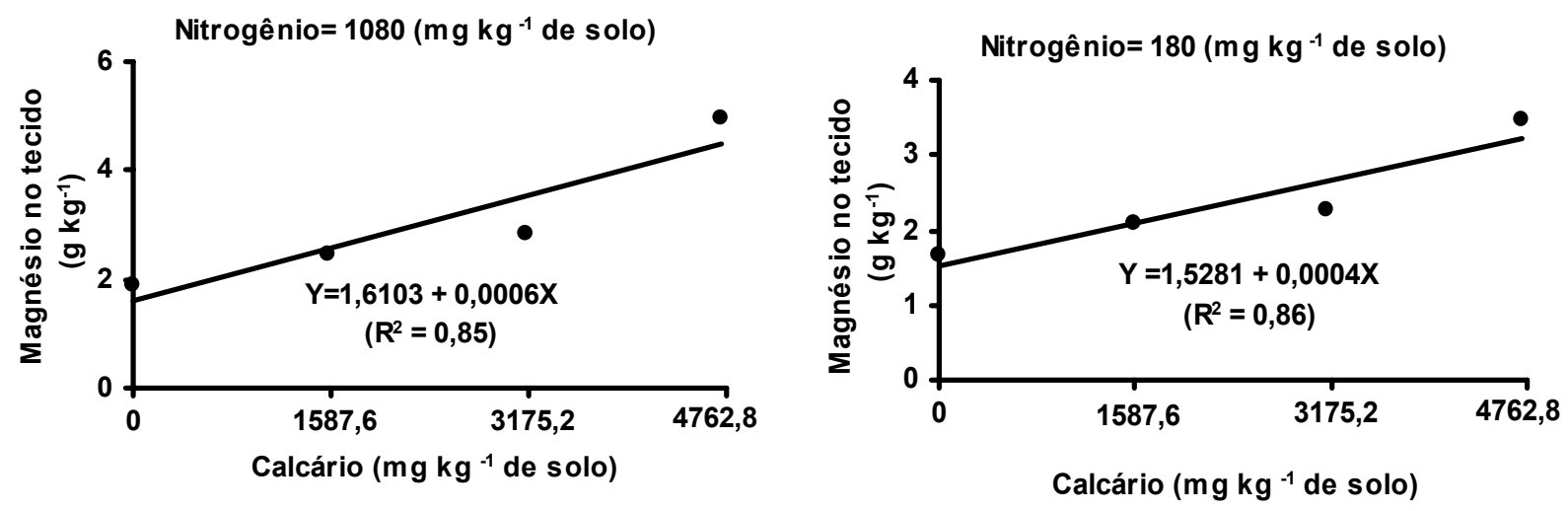

Figura 67 - Concentração de magnésio nas folhas emergentes da Brachiaria decumbens, no primeiro corte, em função das doses de calcário dentro das doses de nitrogênio 180 e $1080 \mathrm{mg} \mathrm{kg}^{-1}$ de solo. 
Nas lâminas das folhas recém-expandidas houve interação significativa $(P<0,05)$ entre doses de enxofre e nitrogênio e entre doses de nitrogênio e calcário, no primeiro corte. No segundo corte não houve efeito significativo $(P>0,05)$ dos nutrientes utilizados. No desdobramento das doses de enxofre dentro das doses de nitrogênio, verificou-se significância $(P<0,05)$ apenas na dose $1080 \mathrm{mg} \mathrm{kg}^{-1}$ de solo (Figura 68). O resultado foi representado por um modelo quadrático e o valor de máxima concentração de magnésio foi encontrado na dose de enxofre de $200 \mathrm{mg} \mathrm{kg}^{-1}$ de solo, dentro da respectiva dose de nitrogênio. A variação na concentração de magnésio foi de 3,46 a 6,14 $\mathrm{g} \mathrm{kg}^{-1}$. Com relação ao nitrogênio, houve significância $(P<0,05)$ para todas as doses de enxofre. Em todos o casos, os resultados se ajustaram a um modelo quadrático e os valores de máxima concentração de magnésio foram obtidos nas doses 606, 818 e $596 \mathrm{mg} \mathrm{kg}^{-1}$ de solo (Figura 69). Os teores de magnésio no tecido em função das doses de nitrogênio dentro das doses de enxofre foram de 2,83 e $6,44 \mathrm{~g} \mathrm{~kg}^{-1}$.

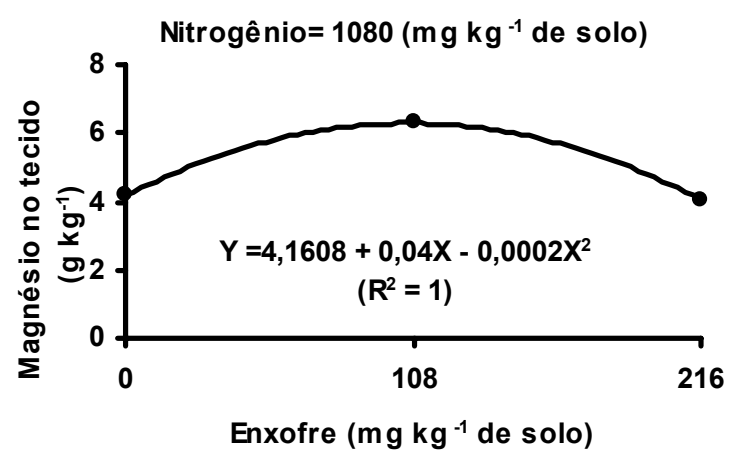

Figura 68 - Concentração de magnésio nas lâminas de folhas recémexpandidas da Brachiaria decumbens, no primeiro corte, em função das doses de enxofre dentro da dose de nitrogênio 1080 $\mathrm{mg} \mathrm{kg}^{-1}$ de solo. 

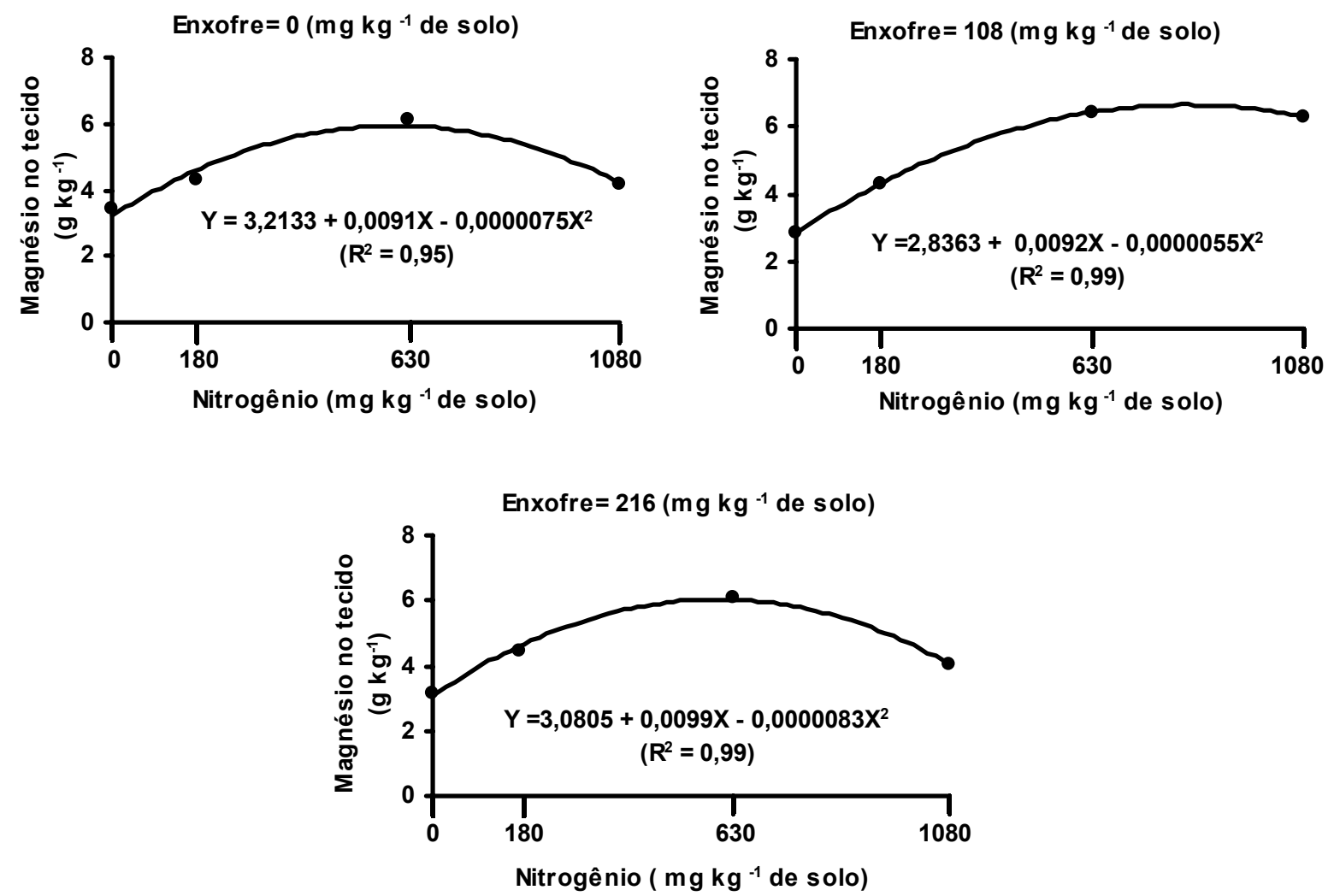

Figura 69 - Concentração de magnésio nas lâminas de folhas recémexpandidas da Brachiaria decumbens, no primeiro corte, em função das doses de nitrogênio dentro de cada dose de enxofre.

$\mathrm{Na}$ interação nitrogênio calcário, observou-se efeito significativo $(P<0,05)$ para as doses de nitrogênio dentro de todas as doses de calcário. Os resultados seguiram um modelo quadrático em todos os casos e os valores de máxima concentração de magnésio foram obtidos nas doses de nitrogênio 500 , 640, 646 e 933,0 $\mathrm{mg} \mathrm{kg}^{-1}$ de solo, dentro das respectivas doses de calcário (Figura 70). Os teores de magnésio no tecido da lâminas de folhas recémexpandidas foram de 2,96 a $7,67 \mathrm{~g} \mathrm{~kg}^{-1}$. O maior valor ocorreu na dose de nitrogênio de $630 \mathrm{mg} \mathrm{kg}^{-1}$ de solo, dentro da dose de calcário de $3175,2 \mathrm{mg} \mathrm{kg}$ ${ }^{1}$ de solo. $\mathrm{Na}$ avaliação das doses de calcário dentro das doses de nitrogênio, foi verificado significância $(P<0,05)$ apenas nas doses 630 e $1080 \mathrm{mg} \mathrm{kg}^{-1}$ de 
solo de nitrogênio. Os efeitos ajustaram-se ao modelo quadrático no primeiro caso e o valor de máxima concentração de magnésio foi encontrado na dose de calcário de $3333,3 \mathrm{mg} \mathrm{kg}^{-1}$ de solo, dentro da respectiva dose de nitrogênio e, a um modelo linear na dose de nitrogênio de $1080 \mathrm{mg} \mathrm{kg}^{-1}$ de solo (Figura 71). A variação nas concentrações de magnésio, em função das doses de calcário dentro das referidas doses de nitrogênio foram de 2,85 a $7,47 \mathrm{~g} \mathrm{~kg}^{-1}$.
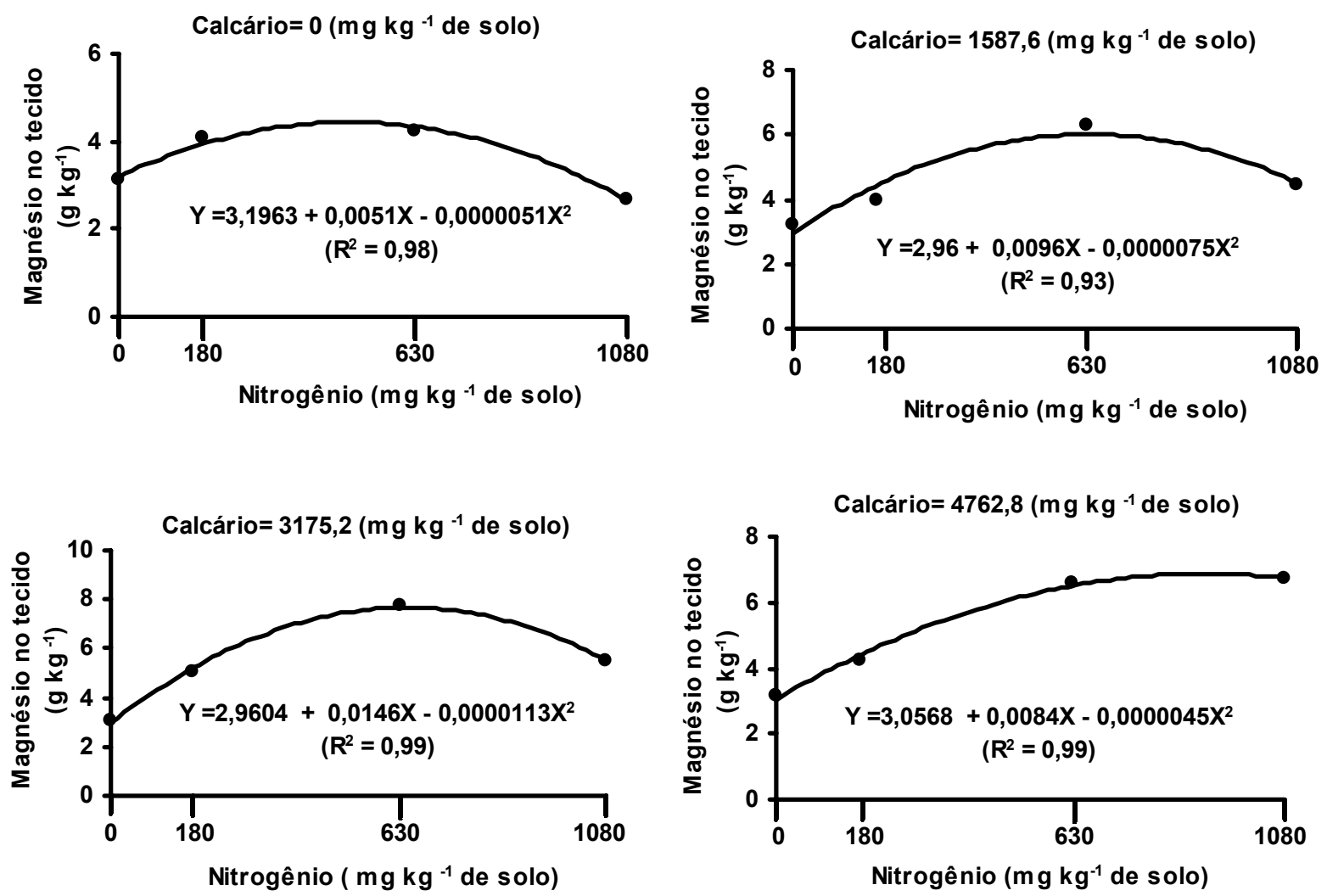

Figura 70 - Concentração de magnésio nas lâminas de folhas recém expandidas da $B$. decumbens, no primeiro corte, em função das doses de nitrogênio dentro das doses de calcário 0, 1587,6, 3175,2 e $4762,8 \mathrm{mg} \mathrm{kg}^{-1}$ de solo. 

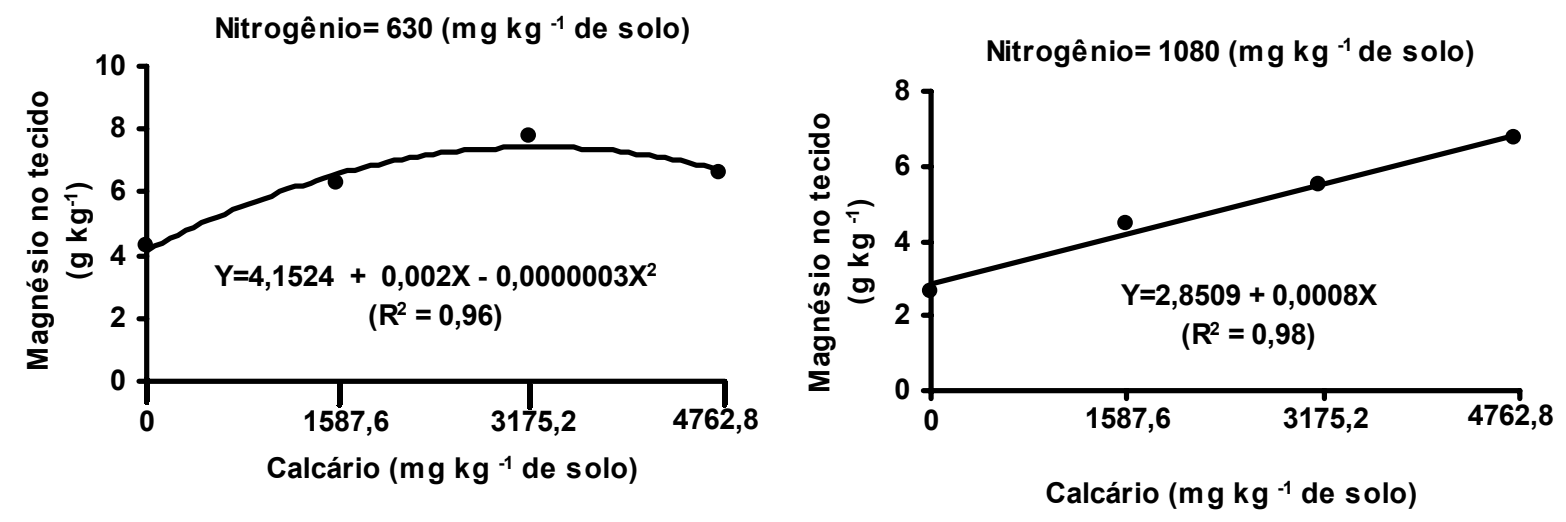

Figura 71 - Concentração de magnésio nas lâminas de folhas recémexpandidas da Brachiaria decumbens, no primeiro corte, em função das doses de calcário dentro das doses de nitrogênio 630 e $1080 \mathrm{mg} \mathrm{kg}^{-1}$ de solo.

As lâminas de folhas maduras, no primeiro corte, apresentaram significância $(P<0,05)$ para as doses de nitrogênio e calcário. Em ambos os casos os efeitos foram demonstrados por um modelo quadrático e os valores de máxima concentração de magnésio nesses componentes da planta, foram obtidos nas doses 566,2 e $6500 \mathrm{mg} \mathrm{kg}^{-1}$ de solo de nitrogênio (Figura 72) e calcário (Figura 73), respectivamente. O valor de máxima concentração de magnésio no tecido em função das doses de calcário ocorreria em doses mais elevadas que as utilizadas nesse estudo. Os teores de magnésio no tecido variaram de 6,60 a $9,23 \mathrm{~g} \mathrm{~kg}^{-1}$ e de 5,95 a 9,88 $\mathrm{g} \mathrm{kg}^{-1}$ em função das doses de nitrogênio e de calcário, respectivamente. 


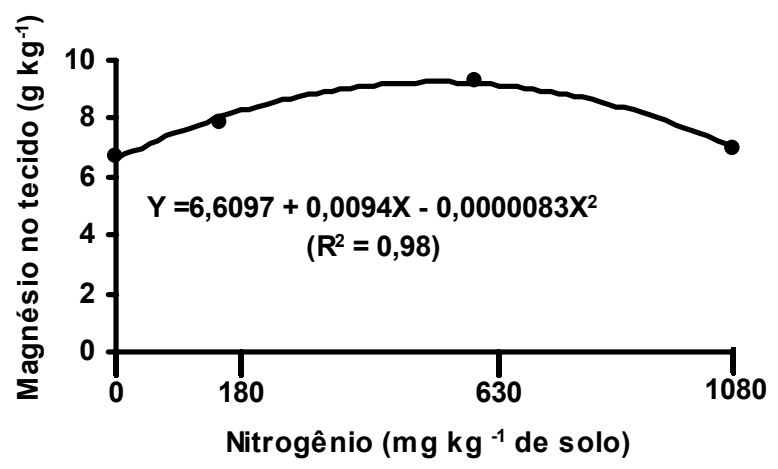

Figura 72 - Concentração de magnésio nas lâminas de folhas maduras da Brachiaria decumbens, no primeiro corte, em função das doses de nitrogênio.

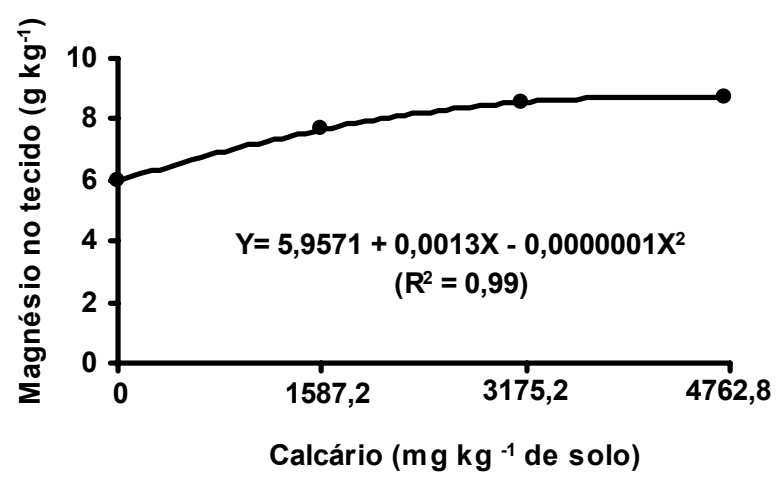

Figura 73 - Concentração de magnésio nas lâminas de folhas maduras da Brachiaria decumbens, no primeiro corte, em função das doses de calcário.

No segundo corte houve efeito significativo $(P<0,05)$ para a interação entre as doses de nitrogênio e calcário na concentração de magnésio nas lâminas de folhas maduras. No estudo das doses de nitrogênio dentro das doses de calcário, foi observado efeito significativo $(P<0,05)$ em todas as doses de calcário (Figura 74$)$. Em todos os casos os resultados seguiram uma equação de segundo grau. Os valores de máxima concentração de magnésio nesses componentes foram alcançados nas doses de nitrogênio dentro das doses de calcário de 625, 715, 996 e $992 \mathrm{mg}$ 
$\mathrm{kg}^{-1}$ de solo. A variação nos teores de magnésio no tecido foram de 3,58 a $19,9 \mathrm{~g} \mathrm{~kg}^{-1}$. A maior concentração do nutriente, foi verificada na maior dose de nitrogênio dentro da dose de calcário de $3175,2 \mathrm{mg} \mathrm{kg}^{-1}$ de solo. Nas doses de calcário dentro das doses nitrogênio, apenas a dose $1080 \mathrm{mg} \mathrm{kg}^{-1}$ de solo, foi significativa $(P<0,05)$ e o resultado foi demonstrado por um modelo linear (Figura 75).
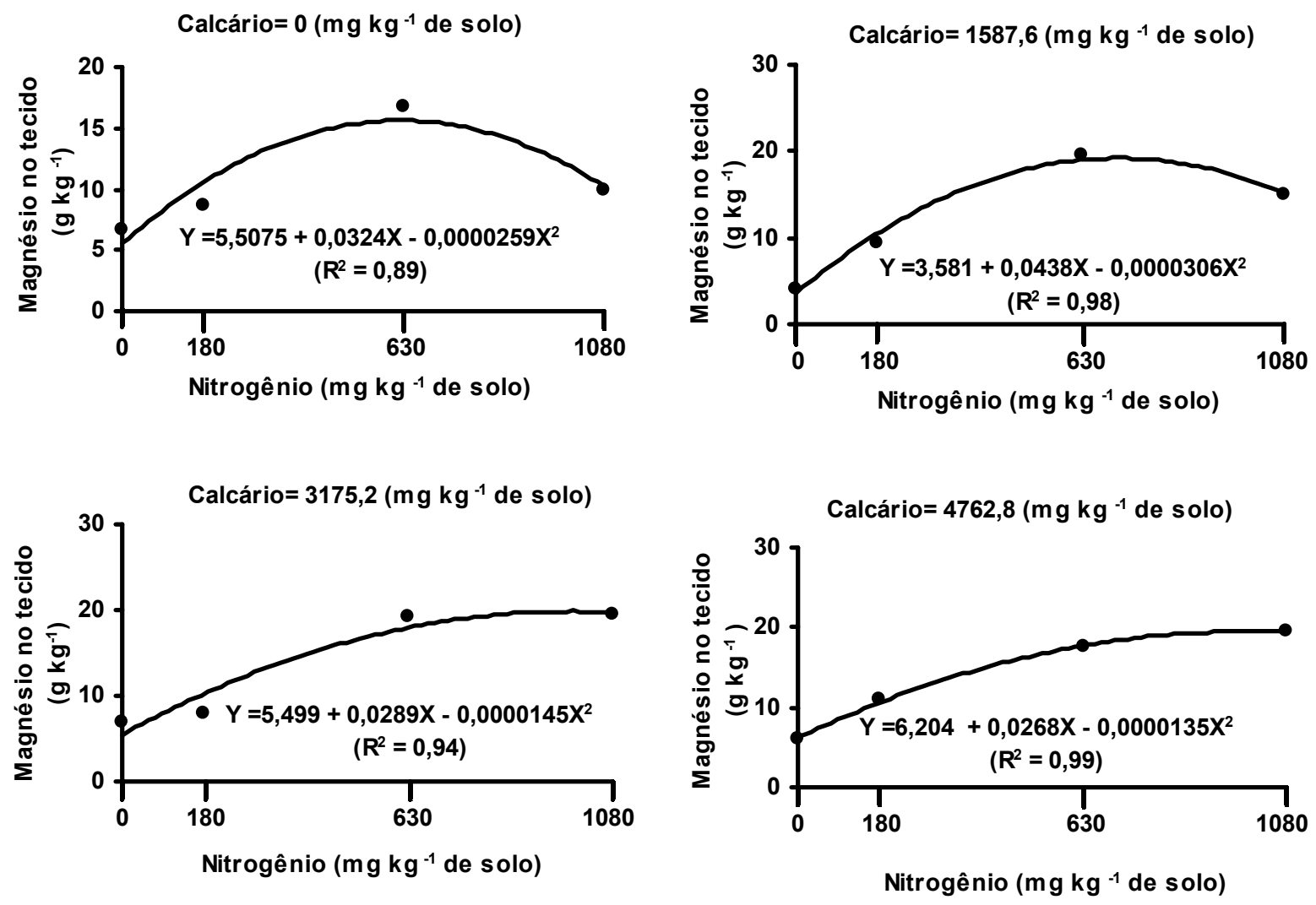

Figura 74 - Concentração de magnésio nas lâminas de folhas maduras da Brachiaria decumbens, no segundo corte, em função das doses de nitrogênio dentro de cada dose de calcário. 


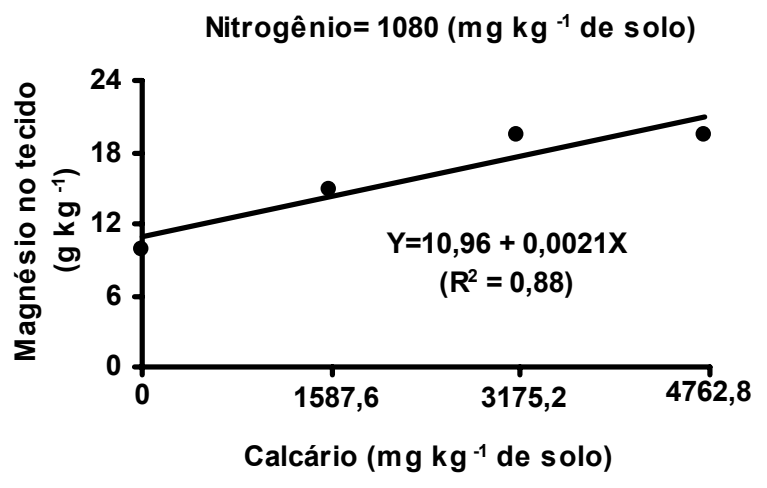

Figura 75 - Concentração de magnésio nas lâminas de folhas maduras da Brachiaria decumbens, no segundo corte, em função das doses de calcário dentro da dose de nitrogênio $1080 \mathrm{mg} \mathrm{kg}^{-1}$ de solo.

A análise de variância para a fração colmos mais bainhas revelou significância $(P<0,05)$ na concentração de magnésio em função da interação entre as doses de nitrogênio e calcário. Avaliando as doses de nitrogênio dentro das doses de calcário, observou-se efeito $(P<0,05)$ para todas as doses de calcário e, em todos os casos os efeitos foram demonstrados por uma equação de segundo grau (Figura 76). Os valores de máxima concentração de magnésio no tecido da planta foram alcançados nas doses de nitrogênio dentro das respectivas doses de calcário de 593, 621 e $865 \mathrm{mg} \mathrm{kg}^{-1}$ de solo. Notou-se que, a variação nas concentrações de magnésio no tecido variaram de 2,09 a $6,66 \mathrm{~g} \mathrm{~kg}^{-1}$ na matéria seca. Esse valor mais elevado nas doses de nitrogênio dentro da dose de calcário de $3175,2 \mathrm{mg} \mathrm{kg}^{-1}$ de solo. 

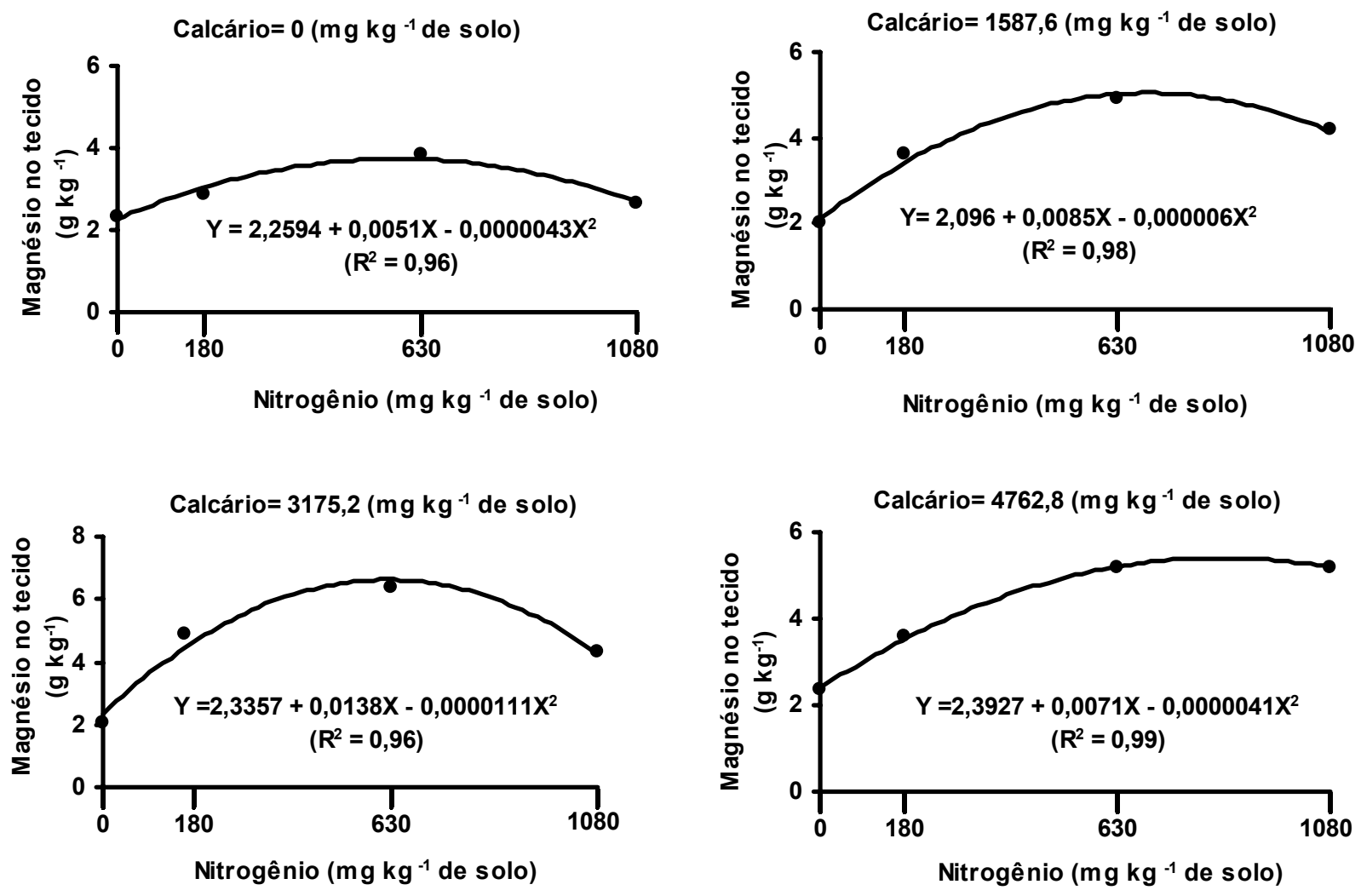

Figura 76 - Concentração de magnésio nos colmos mais bainhas da Brachiaria decumbens, no primeiro corte, em função das doses de nitrogênio dentro de cada dose de calcário.

Nas doses de calcário dentro das doses de nitrogênio, observou-se significância $(P<0,05)$ das doses 180, 630 e $1080 \mathrm{mg} \mathrm{kg}^{-1}$ de solo. Esses resultados foram demonstrados por um modelo quadrático nas doses $180 \mathrm{e}$ $630 \mathrm{mg} \mathrm{kg}^{-1}$ de solo, com os valores de máxima concentração obtidos $3000 \mathrm{e}$ $3500 \mathrm{mg} \mathrm{kg}^{-1}$ de solo. A dose de nitrogênio de $1080 \mathrm{mg} \mathrm{kg}^{-1}$ de solo teve ajuste a um modelo linear (Figura 77). Verificou-se que, os teores de magnésio no tecido variaram de 2,71 a $6,09 \mathrm{~g} \mathrm{~kg}^{-1}$ na matéria seca. 

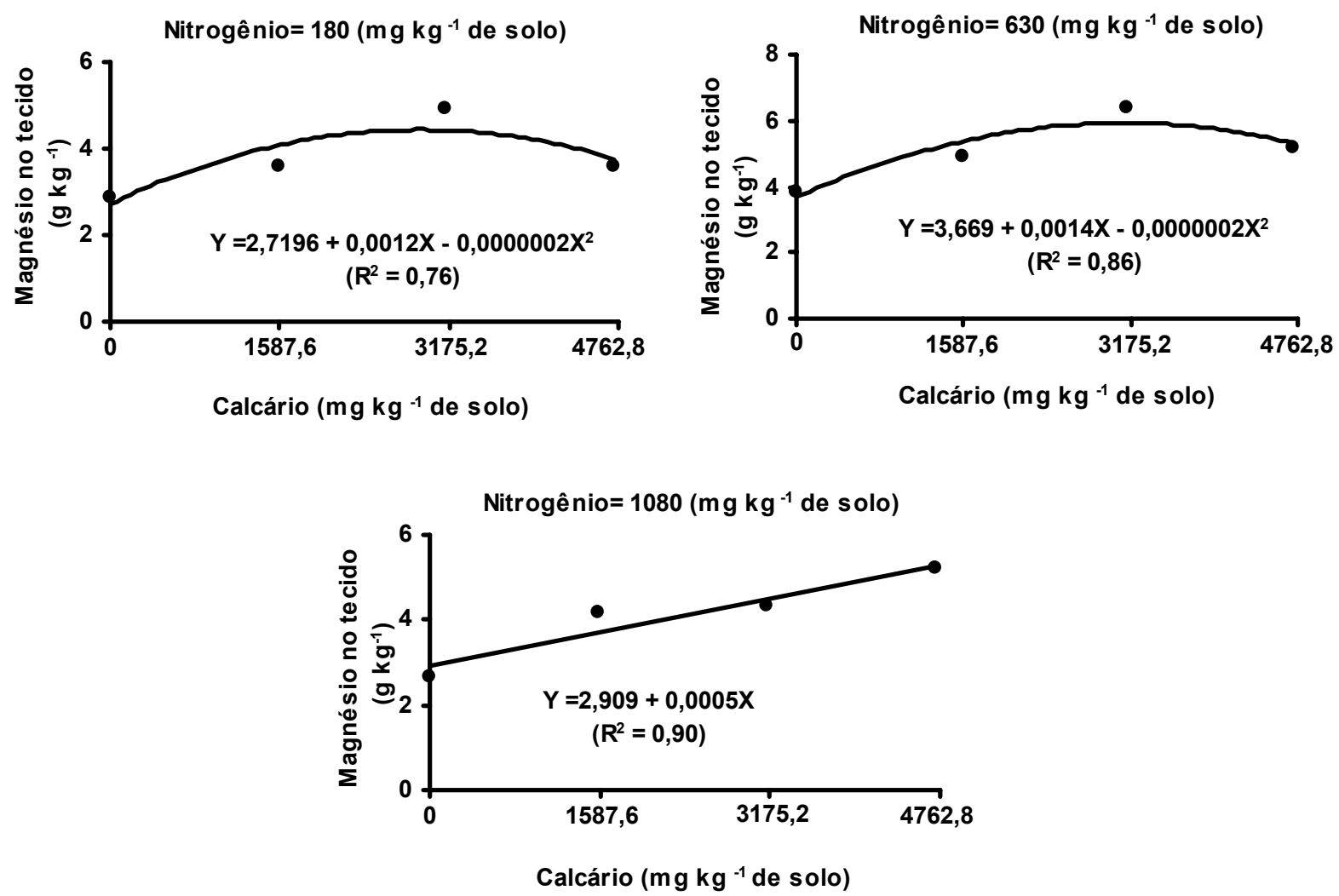

Figura 77 - Concentração de magnésio nos colmos mais bainhas da Brachiaria decumbens, no primeiro corte, em função das doses de calcário dentro das doses de nitrogênio 180, 630 e $1080 \mathrm{mg} \mathrm{kg}^{-1}$ de solo.

A análise de variância para a fração colmos mais bainhas do capimbraquiária, na segunda avaliação, revelou significância $(P<0,05)$ da interação entre doses de enxofre e nitrogênio. $\mathrm{Na}$ avaliação das doses de enxofre dentro das doses de nitrogênio, houve significância $(P<0,05)$ apenas na dose de nitrogênio de $1080 \mathrm{mg} \mathrm{kg}^{-1}$ de solo. $\mathrm{O}$ resultado foi demonstrado por um modelo quadrático, e o ponto de máxima concentração de magnésio, nesse componente, foi observado na dose de enxofre de $91 \mathrm{mg} \mathrm{kg}^{-1}$ de solo, dentro da respectiva dose de nitrogênio (Figura 78 ). Nas doses de nitrogênio dentro das doses de enxofre, verificou-se efeito significativo $(P<0,05)$ para todas as 
doses de enxofre. Esses efeitos foram representados por um modelo linear nas doses 0 e 108 e por um modelo quadrático na dose de enxofre de $216 \mathrm{mg} \mathrm{kg}^{-1}$ de solo (Figura 79). O ponto de máxima concentração de magnésio foi encontrado em $653 \mathrm{mg} \mathrm{kg}{ }^{-1}$ de solo. A variação nas concentrações de magnésio foram de 2,72 a $17,80 \mathrm{~g} \mathrm{~kg}^{-1}$. A mais alta concentração ocorreu nas doses mais elevadas de nitrogênio e enxofre.

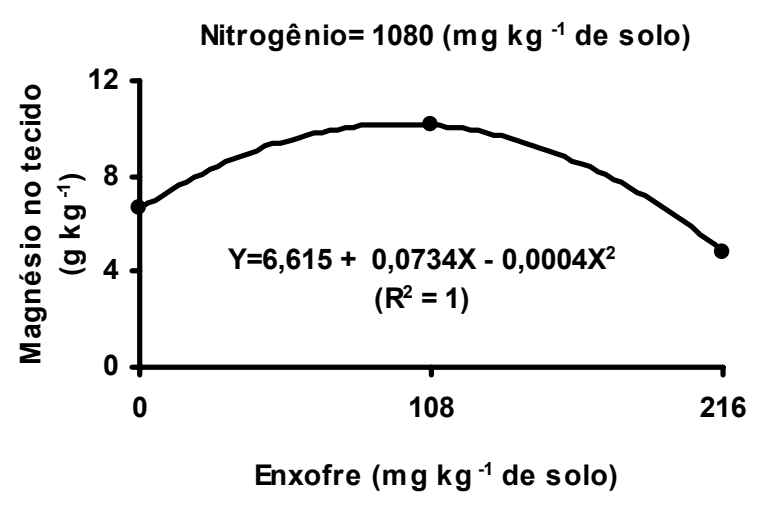

Figura 78 - Concentração de magnésio nos colmos mais bainhas da Brachiaria decumbens, no segundo corte, em função das doses de enxofre dentro da dose de nitrogênio de $1080 \mathrm{mg}$ $\mathrm{kg}^{-1}$ de solo. 

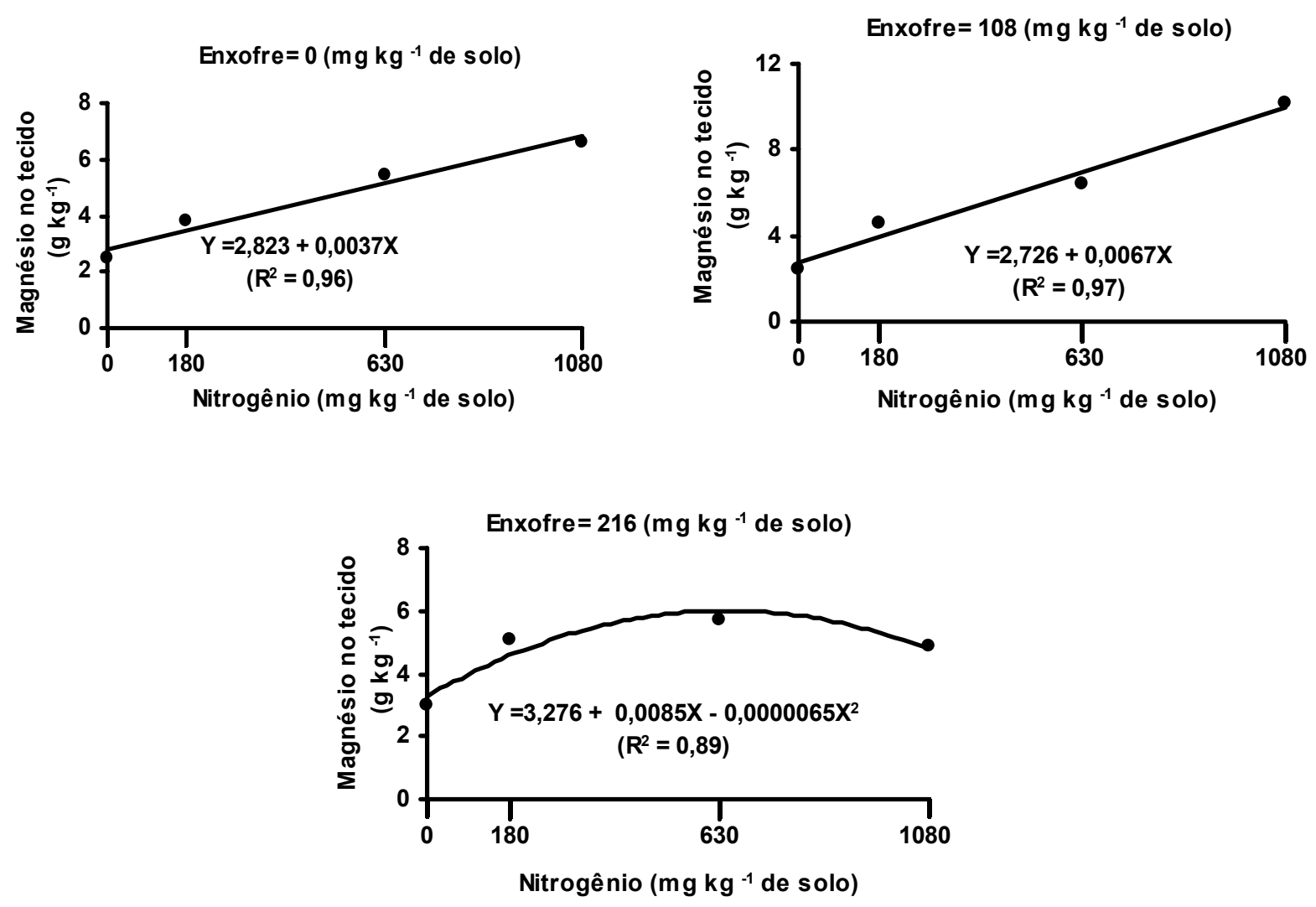

Figura 79 - Concentração de magnésio nos colmos mais bainhas da Brachiariadecumbens, no segundo corte, em função das doses de nitrogênio dentro de cada dose de enxofre.

Analisando cada componente da parte aérea observou-se que, os teores desse elemento aumentaram na planta com a calagem, estando acima dos resultados encontrados na literatura. A maior concentração de magnésio no tecido ocorreu nas lâminas de folhas maduras e nos colmos mais bainhas.

Resultados semelhantes foram encontrados por Werner \& Haag (1972) que, ressaltaram que concentrações mais altas desse nutriente foram encontradas nos colmos mais bainhas, tanto no tratamento completo $(2,7 \mathrm{~g}$ $\left.\mathrm{kg}^{-1}\right)$ quanto na omissão do nutriente $\left(0,7 \mathrm{~g} \mathrm{~kg}^{-1}\right)$. Gallo et al. (1974) avaliando a composição química de forrageiras no estado de São Paulo, encontraram que cerca de $62 \%$ das pastagens analisadas apresentavam 
teores de magnésio na faixa de 1,2 a $2,6 \mathrm{~g} \mathrm{~kg}^{-1}$, enquanto que no restante das forrageiras analisadas a concentração foi mais elevada que $2,6 \mathrm{~g} \mathrm{~kg}^{-1}$.

Faquin et al. (1995) observaram na parte aérea da Brachiaria brizantha cv. Marandu, teores de magnésio entre 1,4 a $5,5 \mathrm{~g} \mathrm{~kg}^{-1}$ no tratamento completo e de $0,7 \mathrm{~g} \mathrm{~kg}^{-1}$ quando foi omitido o magnésio no segundo corte. Monteiro et al. (1995), avaliando a mesma espécie de capim, observaram um teor de magnésio de $3,5 \mathrm{~g} \mathrm{~kg}^{-1}$ no tratamento completo, enquanto no tratamento que não foi suprido esse nutriente obtiveram um valor de $0,4 \mathrm{~g} \mathrm{~kg}^{-1}$.

\subsubsection{Cálcio}

A interação entre as doses de enxofre, nitrogênio e calcário em termos de concentração de cálcio nos componentes da parte aérea estudados não foi significativa $(P>0,05)$, no primeiro e segundo cortes da planta forrageira.

Nas folhas emergentes da braquiária, foi observado significância $(P<0,05)$ para as doses de nitrogênio sobre a concentração de cálcio no tecido, no primeiro corte e interação entre doses de enxofre e nitrogênio, no segundo corte. O resultado para as doses de nitrogênio foi demonstrado por um modelo quadrático e o ponto de máxima foi obtido na dose de nitrogênio de $555 \mathrm{mg}$ $\mathrm{kg}^{-1}$ de solo (Figura 80). Nas doses de enxofre dentro das doses de nitrogênio apenas a dose $1080 \mathrm{mg} \mathrm{kg}^{-1}$ de solo foi significativa $(P<0,05)$ e, o resultado teve ajuste a uma equação de primeiro grau (Figura 81). Já para as doses de nitrogênio dentro das doses de enxofre, não houve efeito $(P>0,05)$ significativo. Os valores de cálcio nesses componentes variaram de 0,80 a 1,52 e de 1,50 a $3,53 \mathrm{~g} \mathrm{~kg}^{-1}$, para as doses de nitrogênio e interação enxofre e nitrogênio, respectivamente. 


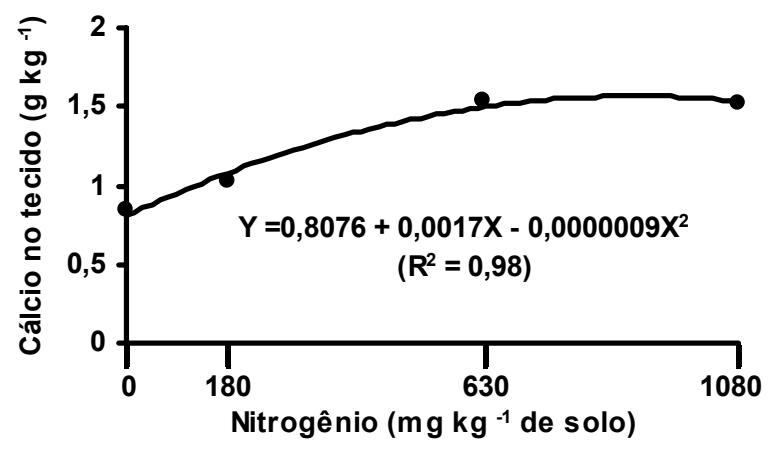

Figura 80 - Concentração de cálcio nas folhas emergentes da Brachiaria decumbens, no primeiro corte, em função das doses de nitrogênio.

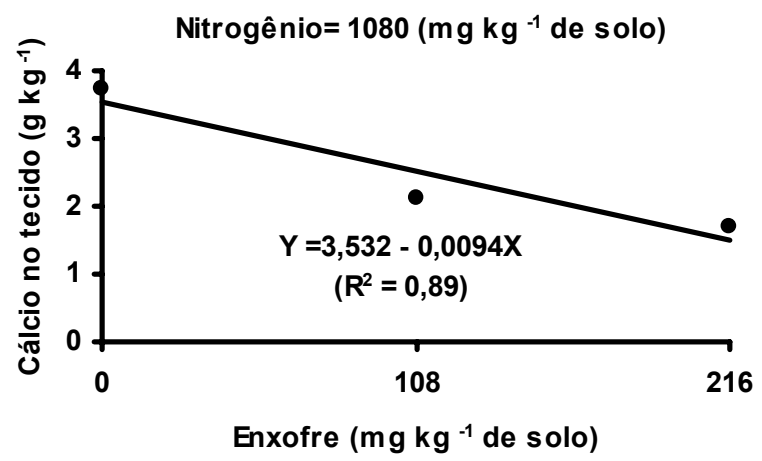

Figura 81 - Concentração de cálcio nas folhas emergentes da Brachiaria decumbens, no segundo corte, em função das doses de enxofre dentro da dose de nitrogênio de $1080 \mathrm{mg} \mathrm{kg}^{-1} \mathrm{de}$ solo.

À medida em que aumentaram as doses de nitrogênio com o mais elevado suprimento de enxofre, a concentração de cálcio nas folhas emergentes do capim-braquiária foram decrescendo, caracterizando um efeito diluição devido ao maior crescimento das plantas, em função da adubação com enxofre e nitrogênio.

As lâminas de folhas recém-expandidas da braquiária, no primeiro corte não apresentaram significância $(P>0,05)$ para nenhum dos nutrientes estudados. Já no segundo corte, houve efeito significativo $(P<0,05)$ para as 
doses de nitrogênio e enxofre. Os resultados seguiram a um modelo linear nas doses de enxofre (Figura 82). As doses de nitrogênio tiveram ajustes a um modelo quadrático de regressão e o valor de máxima concentração de cálcio nesse componente foi encontrado na dose $805 \mathrm{mg} \mathrm{kg}^{-1}$ de solo (Figura 83). Os teores de cálcio, neste componente também, foram decrescentes em função das doses de enxofre. A concentração de cálcio no tecido, em função da adubação nitrogenada variou de 2,93 a $5,46 \mathrm{~g} \mathrm{~kg}^{-1}$. O maior valor foi obtido na dose de nitrogênio de $630 \mathrm{mg} \mathrm{kg}^{-1}$ de solo.

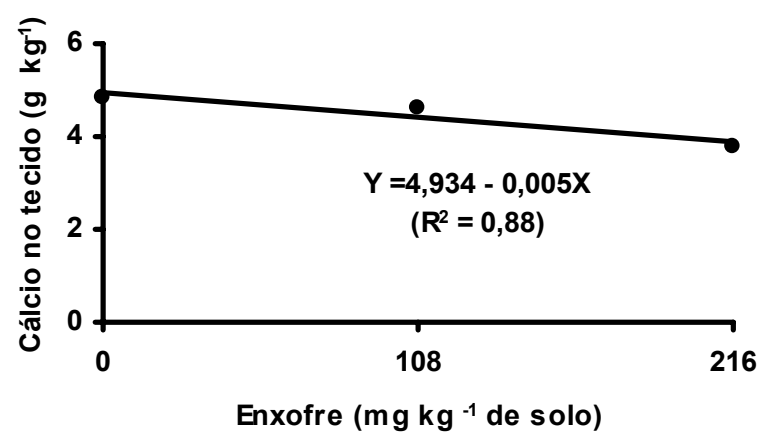

Figura 82 - Concentração de cálcio nas lâminas de folhas recémexpandidas da Brachiaria decumbens, no segundo corte, em função das doses de enxofre.

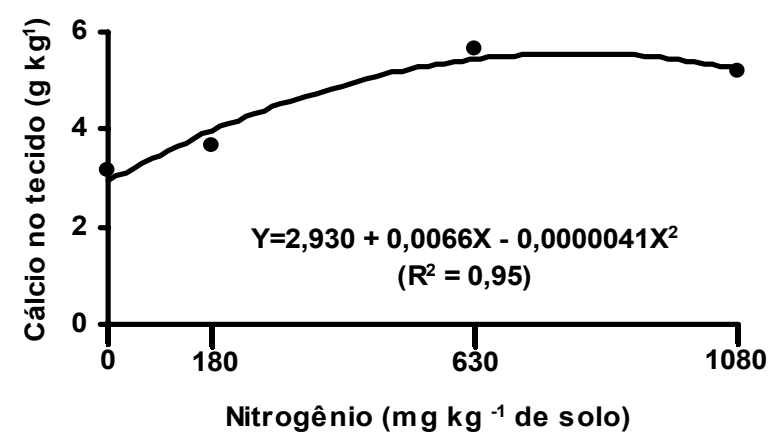

Figura 83 - Concentração de cálcio nas lâminas de folhas recémexpandidas da Brachiaria decumbens, no segundo corte, em função das doses de nitrogênio. 
A análise de variância para a fração lâminas de folhas maduras da braquiária apresentou efeito significativo $(P<0,05)$ para as doses de nitrogênio, no segundo corte e interação entre as doses de enxofre e nitrogênio na duas avaliações. As doses de nitrogênio seguiram uma equação de primeiro grau (Figura 84), indicando que, os teores de cálcio no tecido pode ser ainda maior. Os valores encontrados foram de 5,03 a $8,29 \mathrm{~g} \mathrm{~kg}^{-1}$.

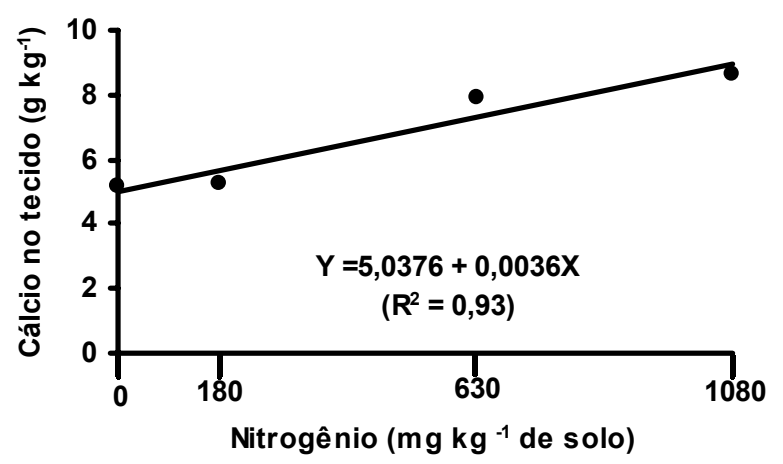

Figura 84 - Concentração de cálcio nas lâminas de folhas maduras da Brachiaria decumbens, no segundo corte, em função das nitrogênio.

As doses de enxofre dentro das doses de nitrogênio, foram significativas $(P<0,05)$ para as doses 0,630 e $1080 \mathrm{~g} \mathrm{~kg}^{-1}$ de solo, no primeiro corte e, tiveram os efeitos demonstrados por um modelo linear na dose $1080 \mathrm{~g} \mathrm{~kg}^{-1}$ de solo e por um modelo quadrático nas doses 0 e 630 $\mathrm{mg} \mathrm{kg}^{-1}$ de solo (Figura 85). Na dose 0 o ponto de mínima foi de $91 \mathrm{mg} \mathrm{kg}^{-1}$ de solo de enxofre, já na dose $1080 \mathrm{~g} \mathrm{~kg}^{-1}$ de solo, ponto de máxima concentração de cálcio no tecido desse componente foi encontrado na dose $163 \mathrm{mg} \mathrm{kg}^{-1}$ de solo. No segundo corte, houve efeito apenas nas doses 630 e $1080 \mathrm{~g} \mathrm{~kg}^{-1}$, que seguiram um modelo linear de regressão, no primeiro caso e a um modelo quadrático no segundo (Figura 86). O ponto de máxima concentração de cálcio foi obtido na dose de enxofre de $119 \mathrm{~g}$ 
$\mathrm{kg}^{-1}$ de solo dentro da dose $1080 \mathrm{~g} \mathrm{~kg}^{-1}$ de solo de nitrogênio. Os teores de cálcio nas lâminas de folhas maduras, em função das doses de enxofre dentro das doses de nitrogênio variaram de 4,59 a $6,76 \mathrm{~g} \mathrm{~kg}^{-1}$, no primeiro corte. No segundo corte a variação foi de 5,66 a $10,41 \mathrm{~g} \mathrm{~kg}^{-1}$.
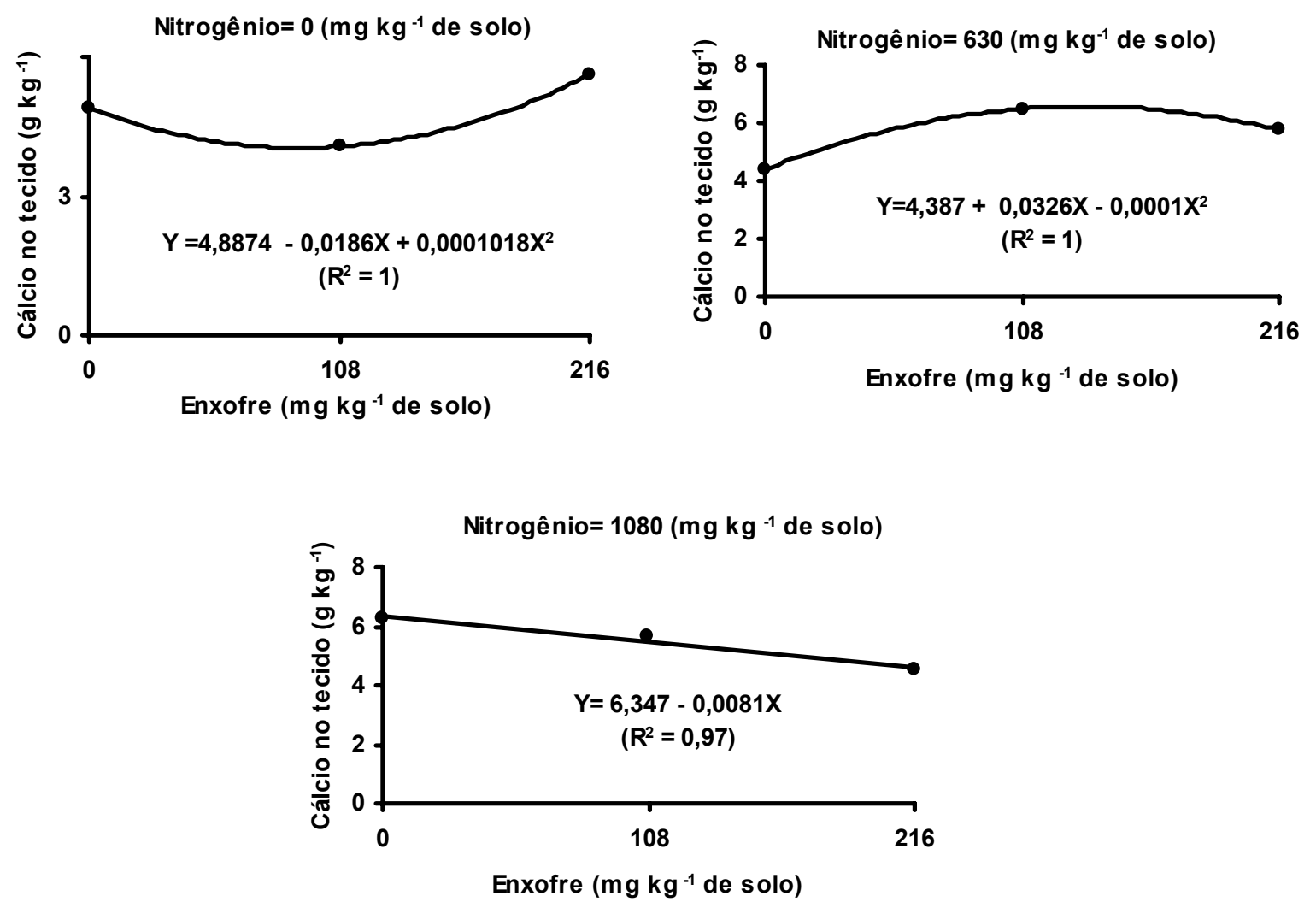

Figura 85 - Concentração de cálcio nas lâminas de folhas maduras da Brachiaria decumbens, no primeiro corte, em função das doses de enxofre dentro das doses de nitrogênio 0,630 e $1080 \mathrm{mg} \mathrm{kg}^{-1}$ de solo. 

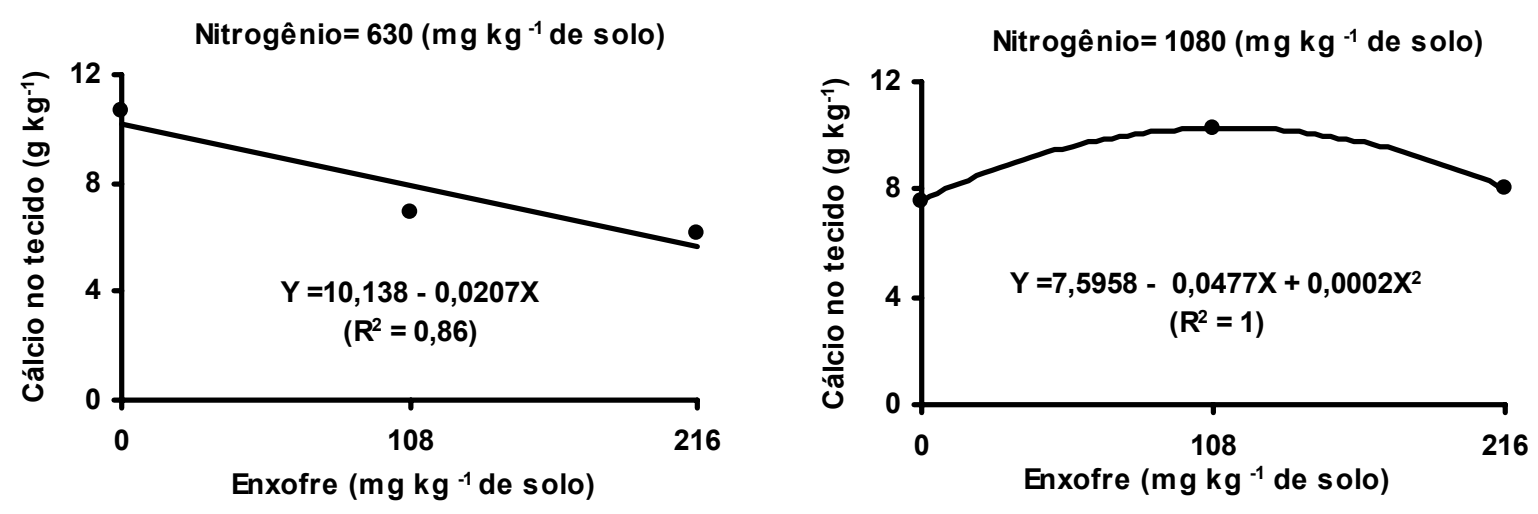

Figura 86 - Concentração de cálcio nas lâminas de folhas maduras da Brachiaria decumbens, no segundo corte, em função das doses de enxofre dentro das doses de nitrogênio.

Avaliando as doses de nitrogênio dentro das doses de enxofre, notou-se efeito significativo $(P<0,05)$ para as doses de enxofre 0 e $108 \mathrm{mg}$ $\mathrm{kg}^{-1}$ de solo, no primeiro corte que tiveram seus efeitos demonstrados por equações do segundo grau. O ponto de mínima foi encontrado em $500 \mathrm{mg}$ $\mathrm{kg}^{-1}$ de solo, enquanto o valor de máxima concentração de cálcio nesse componente foi alcançado em $863 \mathrm{mg} \mathrm{kg}^{-1}$ de solo (Figura 87). A concentração de cálcio no tecido das lâminas de folhas maduras, em função de doses de nitrogênio dentro de doses de enxofre foi de 3,87 a $6,65 \mathrm{~g} \mathrm{~kg}^{-1}$. No segundo corte, todas as doses de enxofre foram significativas $(P<0,05)$. Os efeitos seguiram a um modelo quadrático na dose 0 com ponto de máxima obtido em $676 \mathrm{mg} \mathrm{kg}^{-1}$ de solo e a um modelo linear nas doses de enxofre de108 e $216 \mathrm{mg} \mathrm{kg}^{-1}$ de solo (Figura 88). Os teores de cálcio variaram de 4,32 a $9,87 \mathrm{~g} \mathrm{~kg}^{-1}$. 

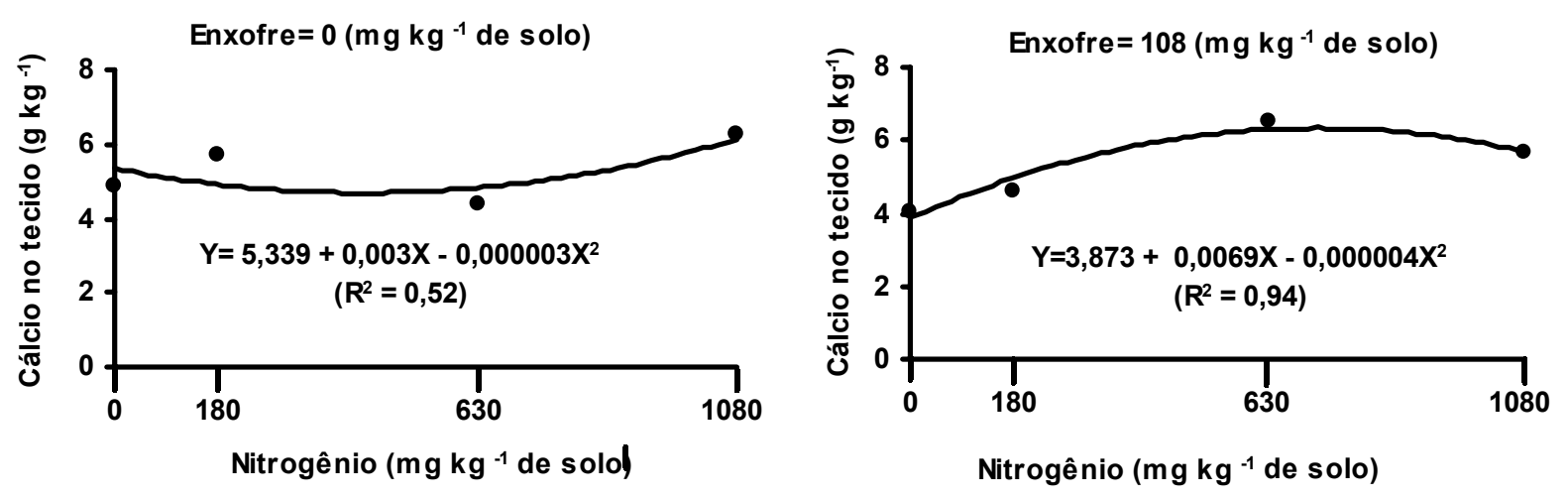

Figura 87 - Concentração de cálcio nas lâminas de folhas maduras da Brachiaria decumbens, no primeiro corte, em função das doses de nitrogênio dentro das doses de enxofre 0 e $108 \mathrm{mg} \mathrm{kg}^{-1}$ de solo.
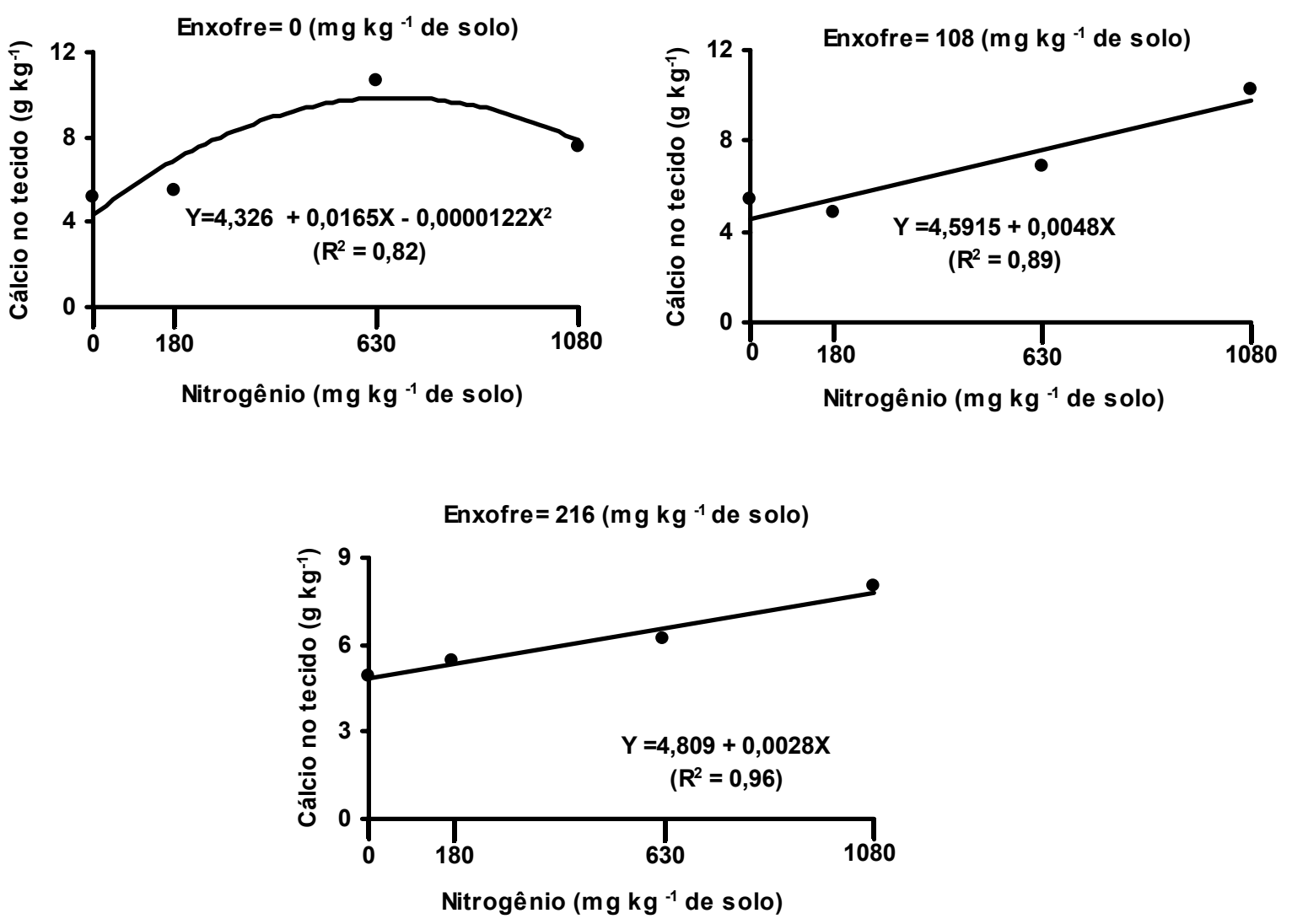

Figura 88 - Concentração de cálcio nas lâminas de folhas maduras da Brachiaria decumbens, no segundo corte, em função das doses de nitrogênio dentro de cada dose de enxofre. 
Os colmos mais bainhas da planta apresentaram efeitos significativos $(P<0,05)$ para as doses de enxofre, no primeiro corte e para as doses de nitrogênio nos dois cortes sobre a concentração de cálcio no tecido. As doses de enxofre tiveram ajuste a um modelo linear (Figura 89). As doses de nitrogênio seguiram um modelo linear, no primeiro corte e a um modelo quadrático no segundo e, o valor de máxima concentração de cálcio foi encontrado em $666,66 \mathrm{~g} \mathrm{~kg}^{-1}$ de solo (Figura 90). Os valores de cálcio nesse componente variaram de 1,72 a 1,14 e de 0,82 a 2,01 $\mathrm{g} \mathrm{kg}^{-1}$, em função das doses de enxofre e de nitrogênio, respectivamente. As doses de enxofre, sobre a concentração de cálcio nos colmos mais bainhas foram decrescentes, caracterizando mais uma vez um efeito diluição.

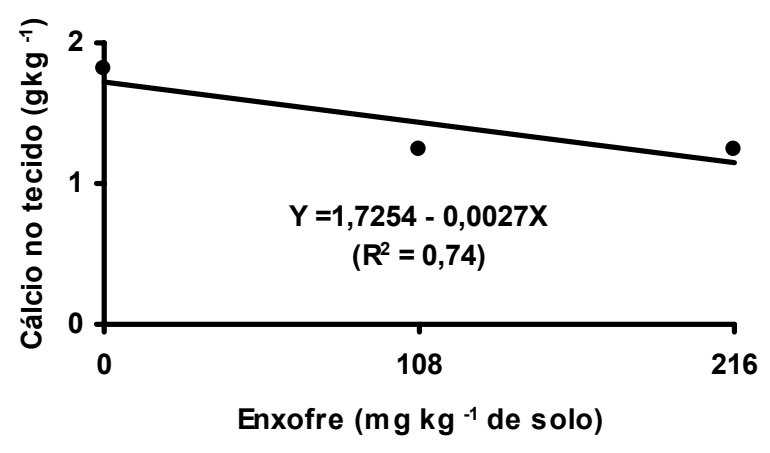

Figura 89 - Concentração de cálcio nas colmos mais bainhas da Brachiaria decumbens, no primeiro corte, em função das doses de enxofre. 


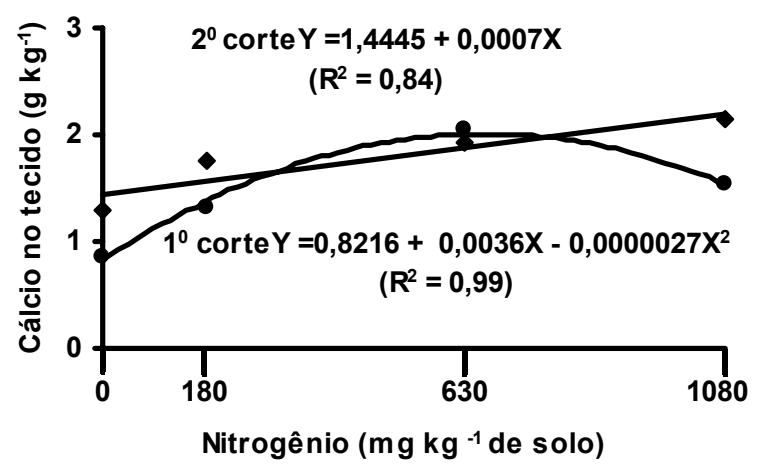

Figura 90 - Concentração de cálcio nas colmos mais bainhas da Brachiaria decumbens, no primeiro e segundo corte, em função das doses de nitrogênio.

A concentração de cálcio encontrada nos componentes da parte aérea do capim foi menor nas folhas emergentes e maiores na lâminas de folhas recém-expandidas e lâminas de folhas maduras. Isso se deve à baixa mobilidade do nutriente na planta. Observou-se que, a calagem não influenciou na concentração de cálcio no tecido, em nenhum dos componentes avaliados.

Esses valores estão dentro da faixa considerada normal para forrageira, que varia de 4 a $8 \mathrm{~g} \mathrm{~kg}^{-1}$ (Gallo et al., 1974). Resultados semelhantes foram encontrados por Mattos (2001) que, avaliando doses de nitrogênio e enxofre na recuperação de uma pastagem degradada de Brachiaria decumbens, encontrou valores entre 2 e $4 \mathrm{~g} \mathrm{~kg}^{-1}$, na lâminas de folhas recém expandidas, na área recentemente adubada.

\subsection{Concentração de micronutrientes nos componentes da parte aérea}

\subsubsection{Cobre}

A análise estatística dos dados da parte aérea da braquiária, indicou haver significância $(P<0,05)$ para as doses de nitrogênio sobre a concentração de cobre no tecido em todos os componentes da parte aérea, no primeiro corte 
e nas lâminas de folhas recém-expandidas e lâminas de folhas maduras, no segundo corte. As folhas emergentes (Figura 91), lâminas de folhas recém expandidas (Figura 92) e colmos mais bainhas (Figura 93), tiveram seus efeitos demonstrados por equações do primeiro grau, no primeiro corte, enquanto nas lâminas de folhas maduras os efeitos foram quadráticos, com ponto de máxima obtido em $238 \mathrm{mg} \mathrm{kg}^{-1}$ de solo (Figura 94). No segundo corte, os efeitos do nitrogênio sobre a concentração de cobre no tecido das lâminas de folhas recém-expandidas foram representados por uma equação de segundo grau com ponto de mínima obtido na dose $288 \mathrm{mg} \mathrm{kg}^{-1}$ de solo, podendo essa dose ser limitante para a nutrição da planta. Nas lâminas de folhas maduras os efeitos foram lineares.

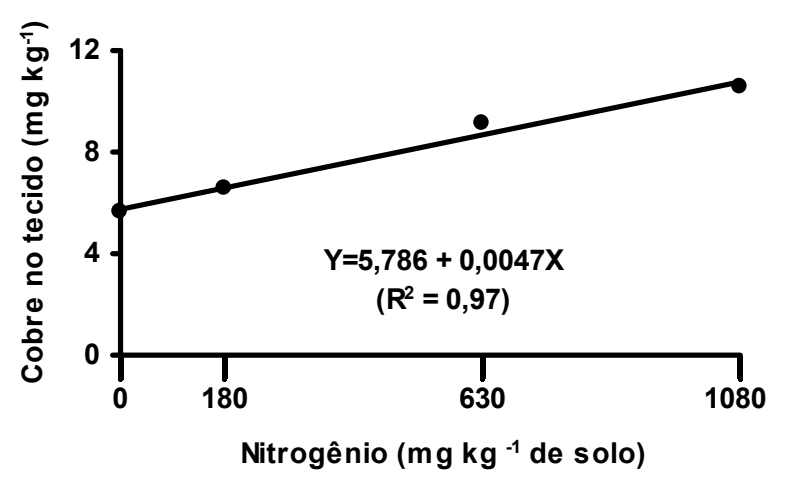

Figura 91 - Concentração de cobre no tecido das folhas emergentes da Brachiaria decumbens, no segundo corte, em função das doses de nitrogênio . 


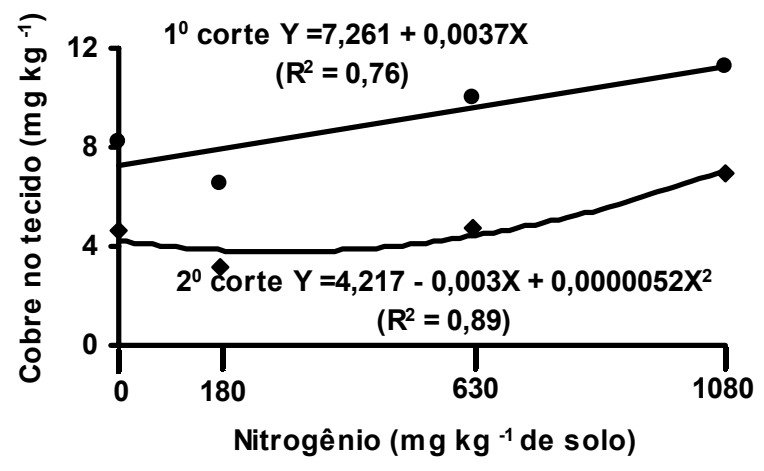

Figura 92 - Concentração de cobre no tecido das lâminas de folhas recém expandidas da Brachiaria. decumbens, no primeiro e segundo corte, em função das doses de nitrogênio .

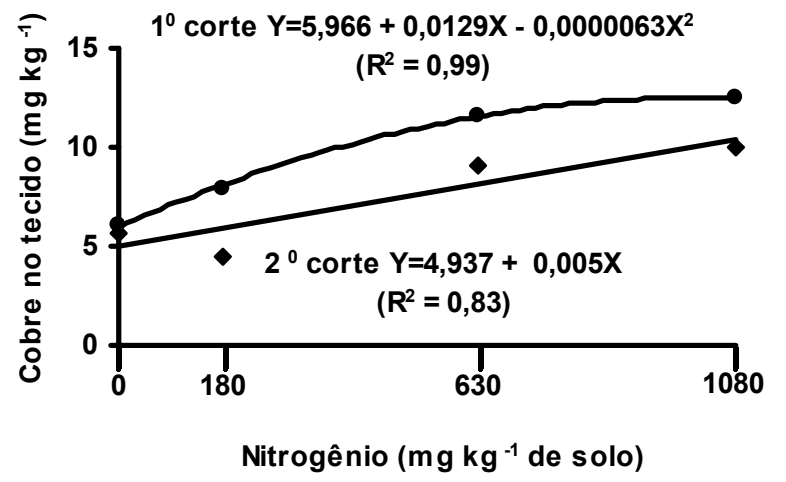

Figura 93 - Concentração de cobre no tecido das lâminas de folhas maduras da Brachiaria decumbens, no primeiro e segundo corte, em função das doses de nitrogênio. 


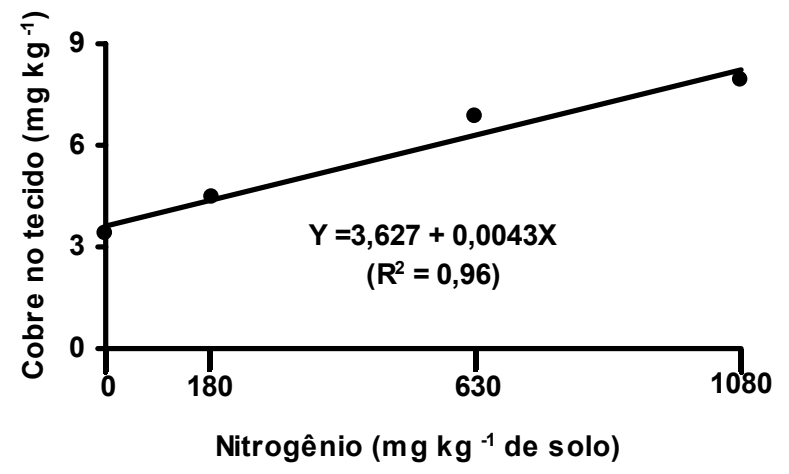

Figura 94 - Concentração de cobre no tecido dos colmos mais bainhas da Brachiaria decumbens, no primeiro corte, em função das doses de nitrogênio.

O comportamento linear das doses de nitrogênio sobre a concentração de cobre na maioria dos componentes indicam que, os valores de cobre poderiam ser ainda maiores que os teores encontrados. Esse comportamento é contrário ao observado por Guimarães (2001). Os valores encontrados variaram entre 3,84 a $12,54 \mathrm{mg} \mathrm{kg}^{-1}$. A maior concentração do nutriente no tecido ocorreu nas lâminas de folhas maduras. Gallo et al. (1974), encontraram valores entre 4 e 8 ppm de cobre no tecido das forrageiras analisadas .

\subsubsection{Ferro}

Analisando os dados de concentração de ferro no tecido em função das doses de nutrientes utilizados, notou-se significância $(P<0,05)$ para as doses de nitrogênio em todos os componentes da parte aérea. Os resultados se ajustaram a um modelo linear nas folhas emergentes nas duas avaliações (Figura 95), lâminas de folhas recém expandidas, no primeiro corte (Figura 96) e lâminas de folhas maduras, nos dois cortes (Figura 97). Os colmos mais bainhas, no primeiro corte (Figura 98) e lâminas de folhas recém-expandidas, no segundo corte, tiveram ajustes a um modelo quadrático. $O$ valor de máxima 
concentração de ferro encontrado no tecido dos colmos mais bainhas, foi obtido na dose $835 \mathrm{mg} \mathrm{kg}^{-1}$ de solo. Nas lâminas de folhas recém-expandidas o valor de mínima foi encontrado em $404 \mathrm{mg} \mathrm{kg}^{-1}$ de solo.

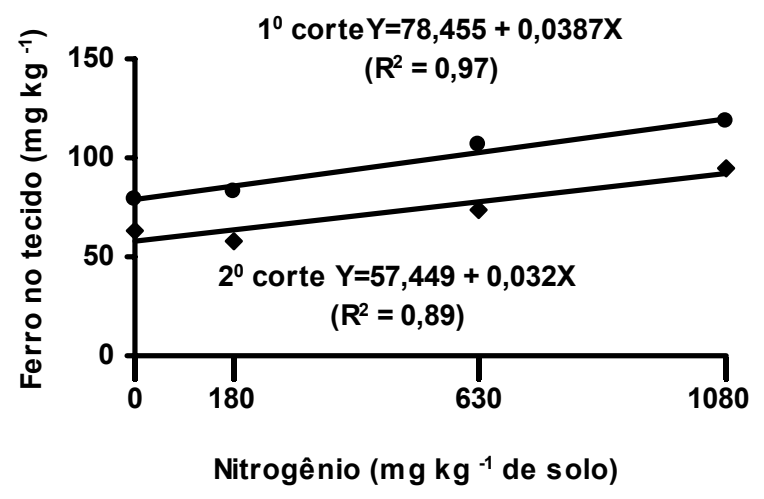

Figura 95 - Concentração de ferro no tecido das folhas emergentes da Brachiaria decumbens, no primeiro e segundo cortes, em função das doses de nitrogênio.

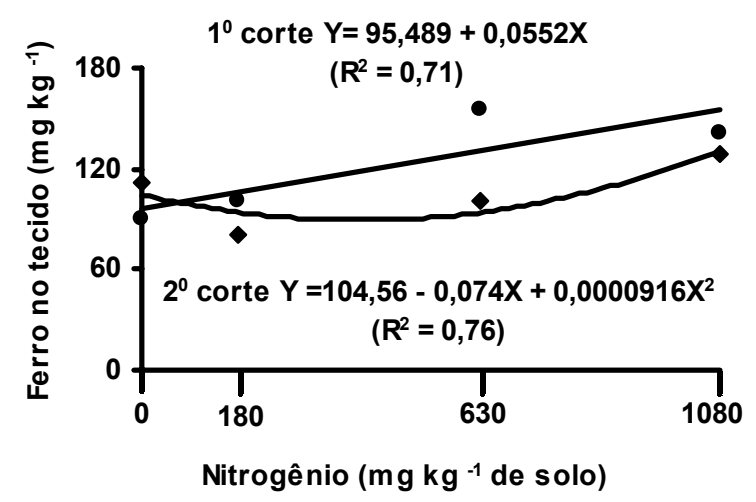

Figura 96 - Concentração de ferro no tecido nas lâminas de folhas recém expandidas da Brachiaria decumbens, no primeiro e segundo cortes, em função das doses de nitrogênio. 


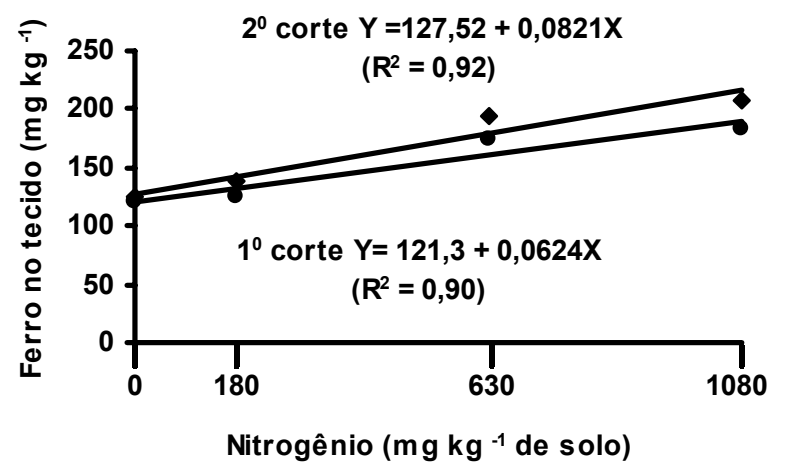

Figura 97 - Concentração de ferro no tecido das lâminas de folhas maduras da Brachiaria decumbens, no primeiro e segundo cortes, em função das doses de nitrogênio.

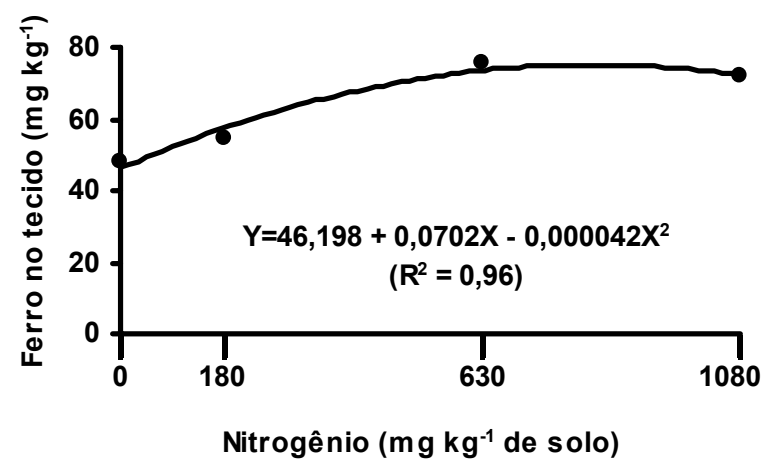

Figura 98 - Concentração de ferro no tecido dos colmos mais bainhas da Brachiaria decumbens, no primeiro corte, em função das doses de nitrogênio.

No segundo corte da planta forrageira, houve efeito significativo $(P<0,05)$ da interação entre doses de nitrogênio e calcário sobre os colmos mais bainhas. No desdobramento da interação observou-se efeito $(P<0,05)$ significativo, apenas para as doses de nitrogênio dentro da dose de calcário de 4762,8 mg $\mathrm{kg}^{-1}$ de solo (Figura 99). Também houve efeito $(P<0,05)$ significativo para as doses de calcário dentro da dose de nitrogênio1080 $\mathrm{mg} \mathrm{kg}^{-1}$ de solo (Figura 
100). Os pontos de mínima foram obtidos em 307 e $1740 \mathrm{mg} \mathrm{kg}^{-1}$ de solo, respectivamente. Esses valores indicam limites para a nutrição da planta em termos de ferro.

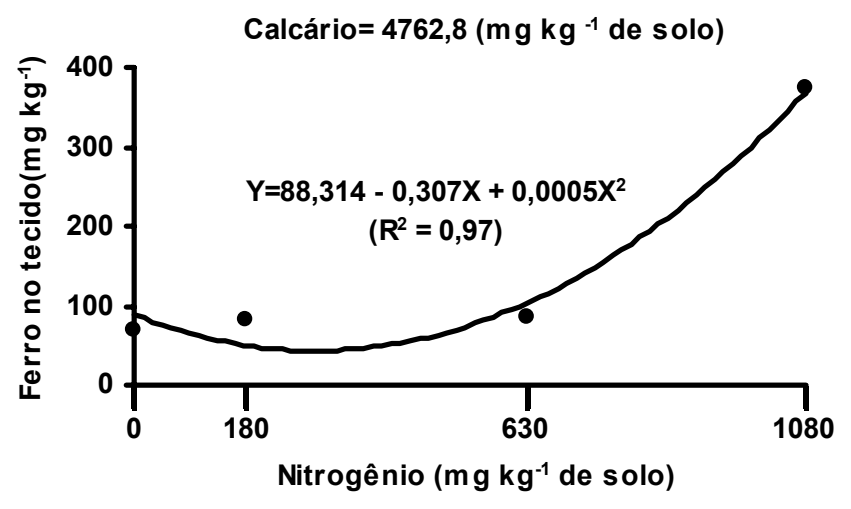

Figura 99 - Concentração de ferro no tecido dos colmos mais bainhas da Brachiaria decumbens, no primeiro corte, em função das doses de nitrogênio dentro da dose de calcário de $4762,8 \mathrm{mg} \mathrm{kg}^{-1}$ de solo.

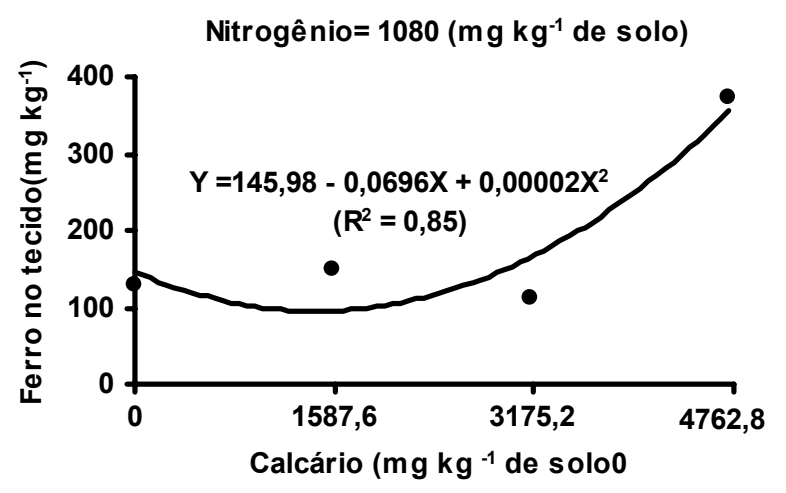

Figura 100 - Concentração de ferro no tecido dos colmos mais bainhas da Brachiaria decumbens, no primeiro corte, em função das doses de calcário dentro da dose de nitrogênio de $1080 \mathrm{mg} \mathrm{kg}^{-1}$ de solo. 
Os teores de ferro encontrados nesse estudo variaram de 57,44 a 268 $\mathrm{mg} \mathrm{kg}^{-1}$. Os maiores valores foram encontrados nos colmos mais bainhas, na interação entre doses de calcário e de nitrogênio, no segundo corte e nas lâminas de folhas maduras.

De acordo com Gallo et al. (1974) devido aos teores geralmente elevados nas plantas, a carência de ferro no animal que vive do pastejo são muito raras, não se constituindo, o ferro em problema. Os mesmos encontraram variação de ferro na forragem entre 10 e 150 ppm.

\subsubsection{Manganês}

A análise de variância para a concentração de manganês no tecido das folhas emergentes da braquiária, revelou significância $(P<0,05)$ para as doses de nitrogênio, na primeira avaliação (Figura 101) e calcário (Figura 102), na duas avaliações. Em todos os casos, os resultados ajustaram-se a um modelo linear.

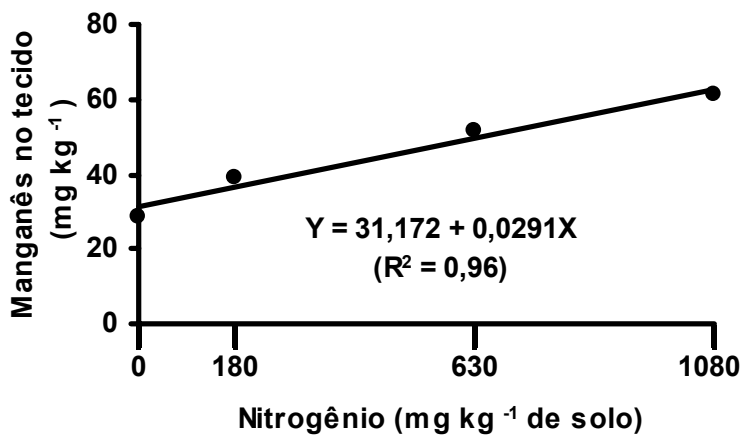

Figura 101 - Concentração de manganês no tecido das folhas emergentes da Brachiaria decumbens, no primeiro corte, em função das doses de nitrogênio. 


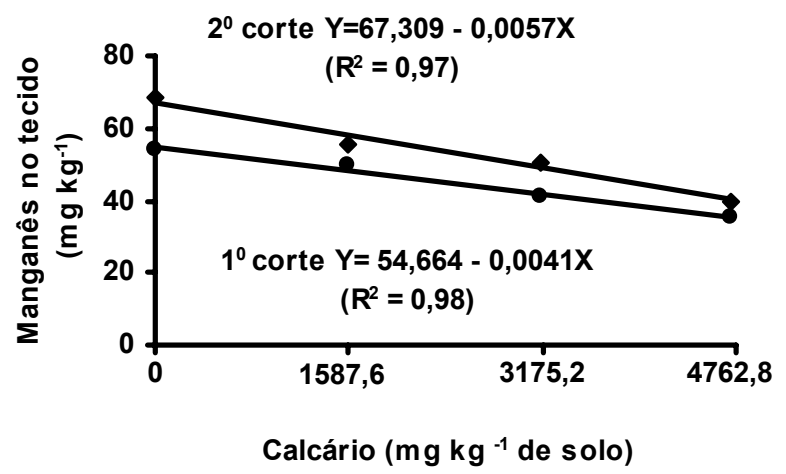

Figura 102 - Concentração de manganês no tecido das folhas emergentes da Brachiaria decumbens, no primeiro e segundo cortes, em função das doses de calcário.

Os teores encontrados no tecido foram de 31,72 a $62,60 \mathrm{mg} \mathrm{kg}^{-1} \mathrm{em}$ função das doses de nitrogênio. A influência das doses de calcário sobre a concentração de manganês no tecido foi explicada por uma reta decrescente. Os resultados concordam com alguns resultados obtidos por Premazzi (1991) e Mitidieri (1995)

Nas lâminas de folhas recém expandidas da forrageira, também houve significância $(P<0,05)$ para as doses de nitrogênio e calcário, no primeiro e segundo cortes. Os efeitos foram demonstrados por um modelo quadrático para as doses de nitrogênio, nas duas avaliações e os pontos de máxima concentração de manganês foram obtidos nas doses 848 e $562 \mathrm{mg} \mathrm{kg}^{-1}$ de solo (Figura 103). Os teores de manganês variaram de 48,50 a $112,96 \mathrm{mg} \mathrm{kg}^{-1}$, sendo que a maior concentração ocorreu na dose de nitrogênio de $1080 \mathrm{mg} \mathrm{kg}^{-1}$ de solo, no segundo corte. As doses de calcário se ajustaram a um modelo linear nas duas avaliações (Figura 104). Mais uma vez, o comportamento do calcário sobre a concentração de manganês no tecido foi linear e decrescente. 


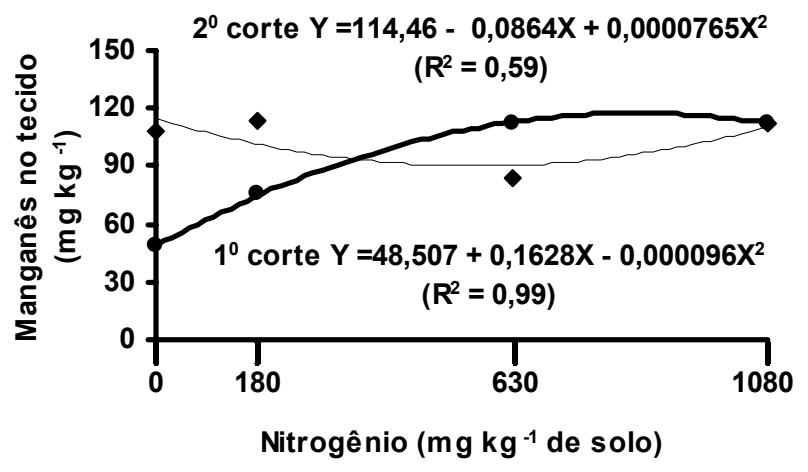

Figura 103 - Concentração de manganês no tecido das lâminas de folhas recém expandidas da Brachiaria decumbens, no primeiro e segundo cortes, em função das doses de nitrogênio.

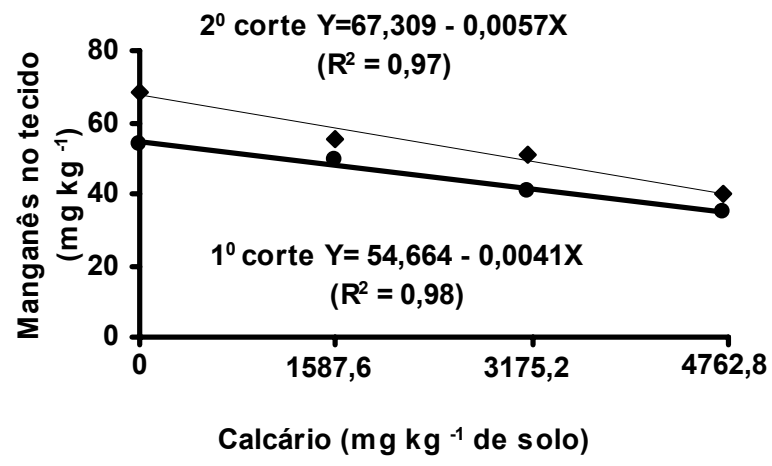

Figura 104 - Concentração de manganês no tecido das lâminas de folhas recém expandidas da Brachiaria decumbens, no primeiro e segundo cortes, em função das doses de calcário.

As lâminas de folhas maduras apresentaram significância $(P<0,05)$ para as doses de nitrogênio no primeiro corte e calcário nas duas avaliações. Os resultados seguiram ajuste a um modelo linear nas doses de nitrogênio (Figura 105) e nas doses de calcário, no segundo corte (Figura 106). No primeiro corte, as doses de calcário tiveram ajuste ao modelo quadrático com o valor de mínima concentração de manganês encontrado na dose de calcário de 4548,3 
$\mathrm{mg} \mathrm{kg}^{-1}$ de solo. Os teores de manganês variaram de 130,96 a $234,84 \mathrm{mg} \mathrm{kg}^{-1}$ em função das doses de nitrogênio. Novamente, o aumento das doses de calcário reduziram a concentração de manganês no tecido.

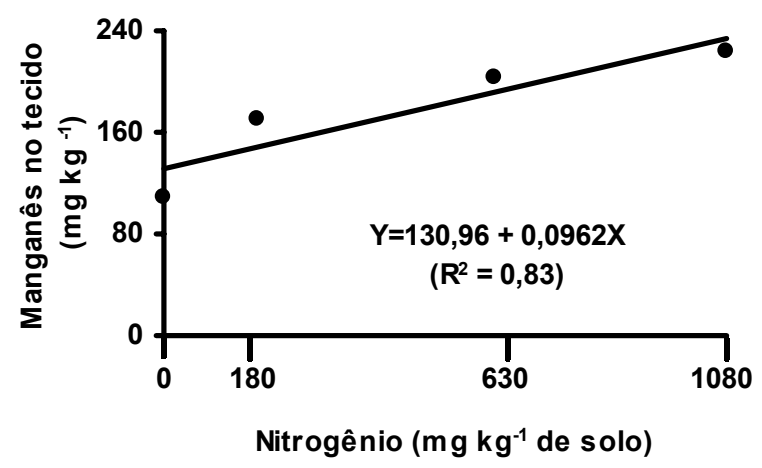

Figura 105 - Concentração de manganês no tecido das lâminas de folhas maduras da Brachiaria decumbens, no primeiro corte, em função das doses de nitrogênio.

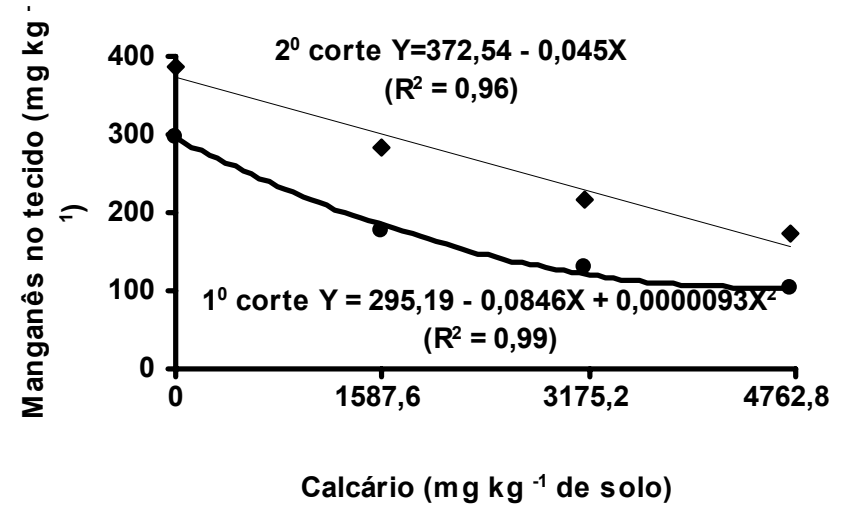

Figura 106 - Concentração de manganês no tecido das lâminas de folhas maduras da Brachiaria decumbens, nas duas avaliações, em função das doses de calcário.

A fração colmos mais bainhas também apresentaram significância $(P<0,05)$ para as doses de nitrogênio e calcário, nas duas avaliações. Os 
resultados foram mostrados por um modelo quadrático nas doses de nitrogênio, com o ponto de máxima concentração de manganês alcançado na dose $728 \mathrm{mg}$ $\mathrm{kg}^{-1}$ de solo, o ponto de mínima, no segundo corte foi de $79 \mathrm{mg} \mathrm{kg}^{-1}$ de solo. (Figura 107) . A variação na concentração de manganês foi de 6244 a 192,23 $\mathrm{mg} \mathrm{kg}^{-1}$. As doses de calcário tiveram um comportamento linear decrescente (Figura 108).

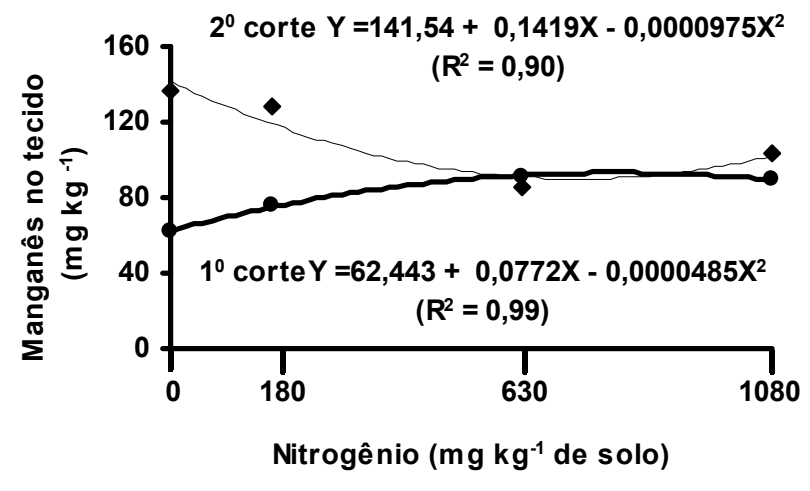

Figura 107 - Concentração de manganês no tecido dos colmos mais bainhas da Brachiaria decumbens, no primeiro e segundo cortes, em função das doses de nitrogênio.

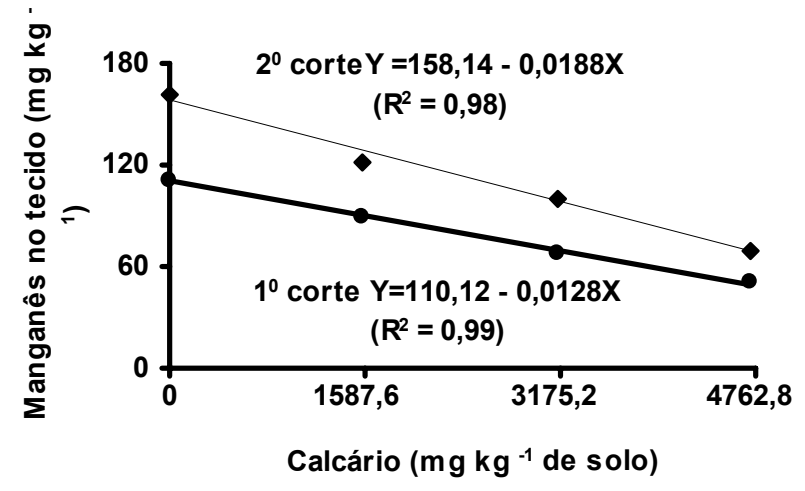

Figura 108 - Concentração de manganês no tecido dos colmos mais bainhas da Brachiaria decumbens, no primeiro e segundo cortes, em função das doses de calcário. 
As doses de nitrogênio sobre a concentração de manganês no tecido, com exceção das lâminas de folhas recém-expandidas tiveram comportamento linear, podendo a concentração desse nutriente ser ainda maior quando se utiliza doses de nitrogênio maiores que as empregadas nesse estudo. Já as doses de calcário influenciaram a concentração de manganês de forma negativa, em todos os casos. Os componentes de maiores concentrações foram os colmos mais bainhas. Os resultados encontrados, situam-se próximo dos valores obtidos por Gallo et al. (1974) que, encontraram valores entre 40 e 200 ppm nas forrageiras analisadas.

\subsubsection{Zinco}

A análise de variância mostrou significância $(P<0,05)$ para as doses de nitrogênio nas duas avaliações, calcário no primeiro corte e para a interação entre as doses de nitrogênio e enxofre no segundo corte, sobre a concentração de zinco no tecido das folhas emergentes da braquiária. As doses de nitrogênio, no primeiro corte se ajustaram a um modelo quadrático, com o ponto de máxima encontrado na dose $1053 \mathrm{mg} \mathrm{kg}^{-1}$ de solo e a um modelo linear, no segundo corte (Figura 109). Os teores de zinco variaram de 18,96 a 82,70 mg $\mathrm{kg}^{-1}$. As doses de calcário tiveram ajuste a um modelo linear (Figura 110). As doses de nitrogênio aumentaram os teores de zinco no tecido, enquanto as de calcário diminuíram. 


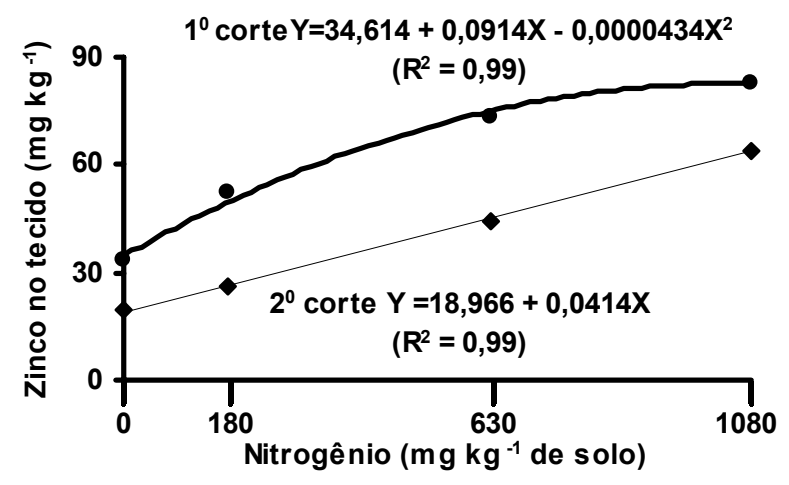

Figura 109 - Concentração de zinco no tecido das folhas emergentes da Brachiaria decumbens, no primeiro e segundo cortes, em função das doses de nitrogênio.

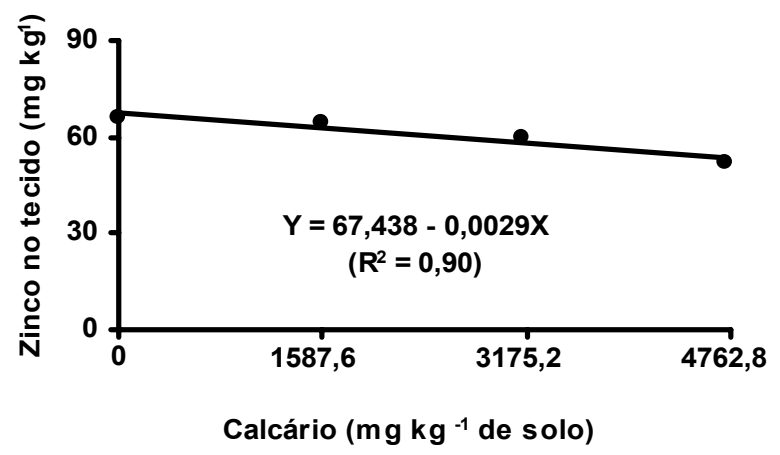

Figura 110 - Concentração de zinco no tecido das folhas emergentes da Brachiaria decumbens, no primeiro corte, em função das doses de calcário.

No segundo corte, houve efeito significativo $(P<0,05)$ para a interação entre doses de enxofre e de nitrogênio. Nas doses de enxofre dentro das doses de nitrogênio, apenas as doses 180 e $1080 \mathrm{mg} \mathrm{kg}^{-1}$ de solo foram significativas $(P<0,05)$, nos dois casos seus efeitos foram demonstrados por um modelo linear (Figura 111). Já nas doses de nitrogênio dentro das doses de enxofre, houve significância $(P<0,05)$ para todas as doses de enxofre. Os resultados tiveram ajuste a um modelo quadrático na dose 0 , com ponto de mínima obtido 
em $15 \mathrm{mg} \mathrm{kg}^{-1}$ de solo e a um modelo linear nas doses 108 e $216 \mathrm{mg} \mathrm{kg}^{-1} \mathrm{de}$ solo (Fiaura 112).
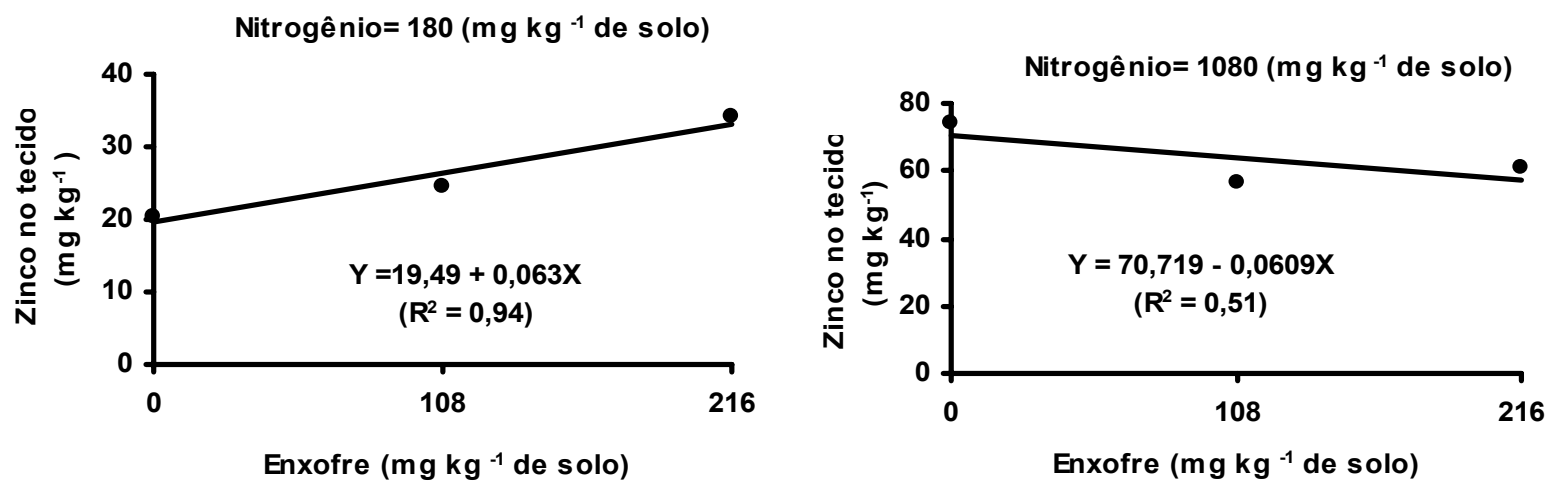

Figura 111 - Concentração de zinco no tecido das folhas emergentes da Brachiaria decumbens, no segundo corte, em função das doses enxofre dentro das doses 180 e $1080 \mathrm{mg} \mathrm{kg}^{-1}$ de solo de nitrogênio.
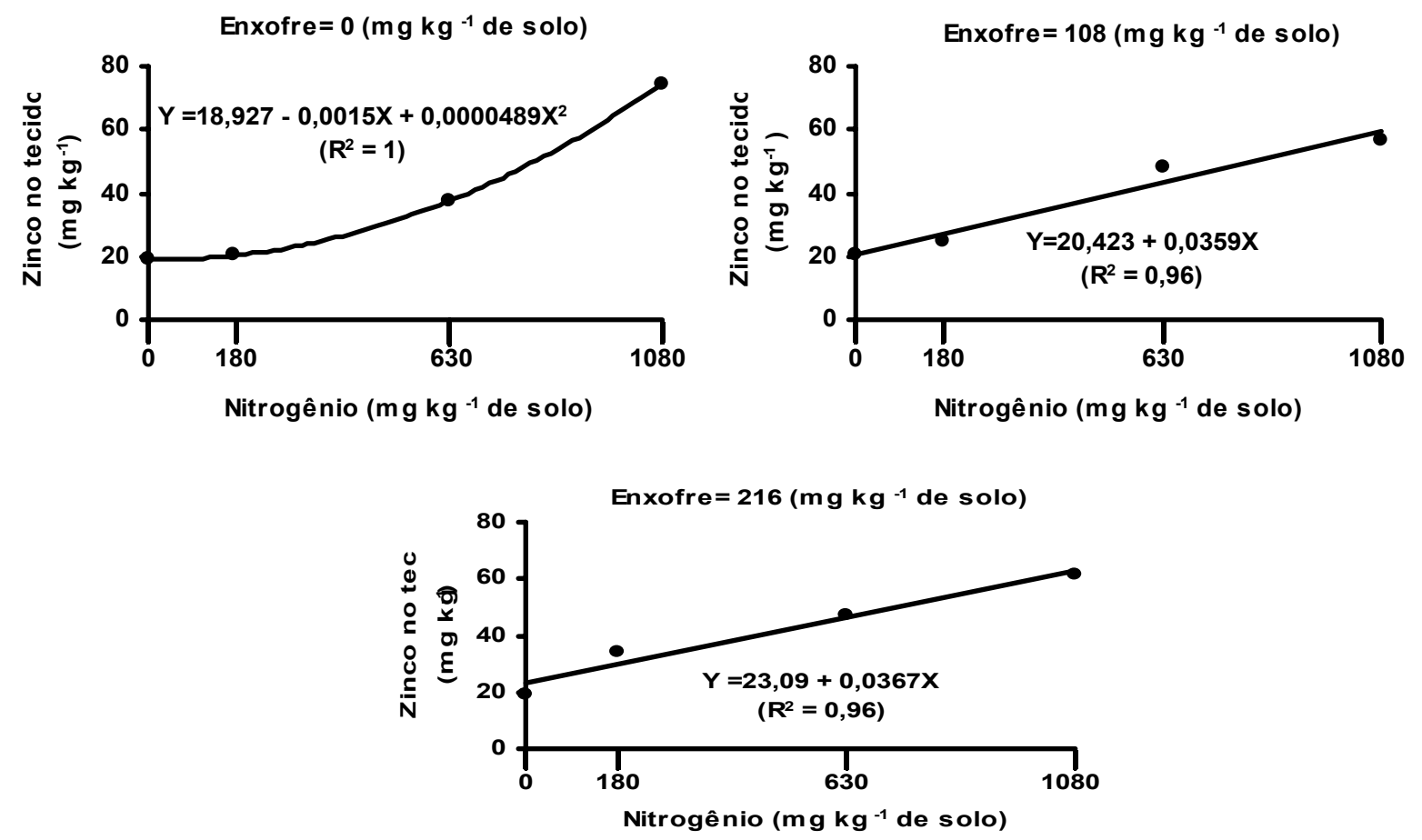

Figura 112 - Concentração de zinco no tecido das folhas emergentes da Brachiaria decumbens, no segundo corte, em função das doses de nitrogênio dentro de cada dose de enxofre. 
$\mathrm{Na}$ fração lâminas de folhas recém expandidas da braquiária, também houve significância $(P<0,05)$ para as doses de nitrogênio e calcário, no primeiro e segundo cortes e interação entre enxofre e nitrogênio, no segundo corte. As doses de nitrogênio se ajustaram a um modelo quadrático nas duas avaliações, sendo o ponto de mínima obtido em $174 \mathrm{mg} \mathrm{kg}^{-1}$ de solo e, o ponto de máxima encontrado na dose $1014 \mathrm{mg} \mathrm{kg}^{-1}$ de solo (Figura113). As doses de calcário tiveram ajustes a um modelo linear nos dois cortes (Figura114).

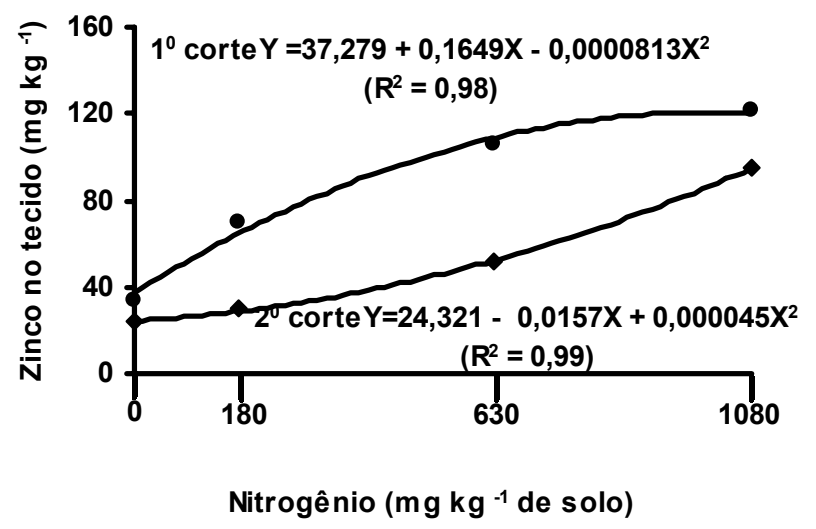

Figura 113 - Concentração de zinco no tecido das folhas recém expandidas da Brachiaria decumbens, no primeiro e segundo cortes, em função das doses de nitrogênio.

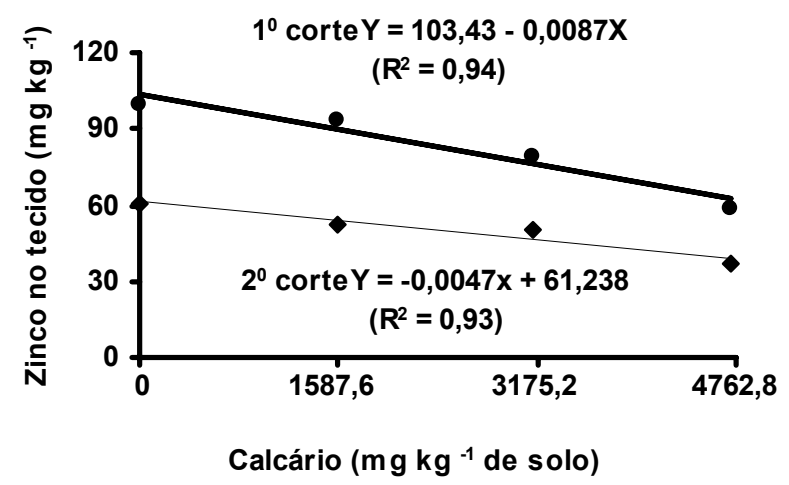

Figura 114 - Concentração de zinco no tecido das folhas recém expandidas da Brachiaria decumbens, no primeiro e segundo corte, em função das doses de calcário. 
No desdobramento das doses de enxofre dentro das doses de nitrogênio, observou-se que, apenas a dose $1080 \mathrm{mg} \mathrm{kg}^{-1}$ de solo, foi significativa $(P<0,05)$. Esse efeito foi demonstrado por um modelo quadrático e o valor de mínima concentração de zinco, foi alcançado mediante a dose $92 \mathrm{mg} \mathrm{kg} \mathrm{ha}^{-1}$ de solo (Figura 115). Nas doses de nitrogênio dentro das doses de enxofre, todas as doses foram significativas (Figura 116). Os resultaram ajustaram-se a um modelo linear na dose 108 e a um modelo quadrático nas doses 0 e $216 \mathrm{mg}$ $\mathrm{kg}^{-1}$ de solo. A ponto de máxima foi encontrado em $340 \mathrm{mg} \mathrm{kg}^{-1}$ de solo.

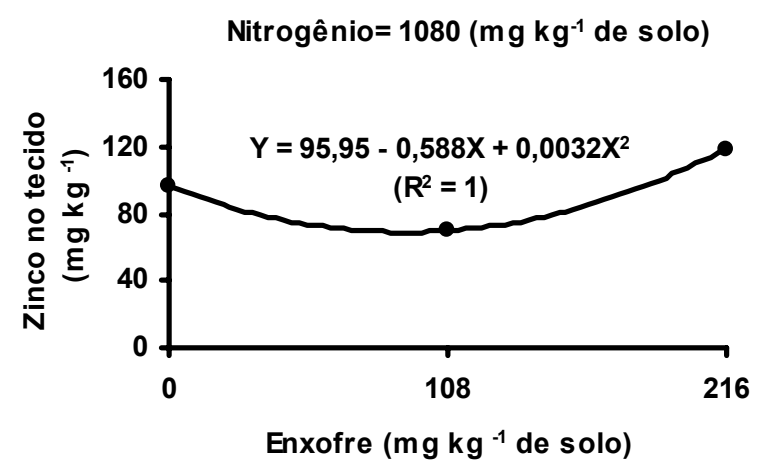

Figura 115 - Concentração de zinco no tecido das folhas recém expandidas da Brachiaria decumbens, no segundo corte, em função das doses de enxofre dentro da dose $1080 \mathrm{mg} \mathrm{kg}^{-1}$ de solo de nitrogênio. 

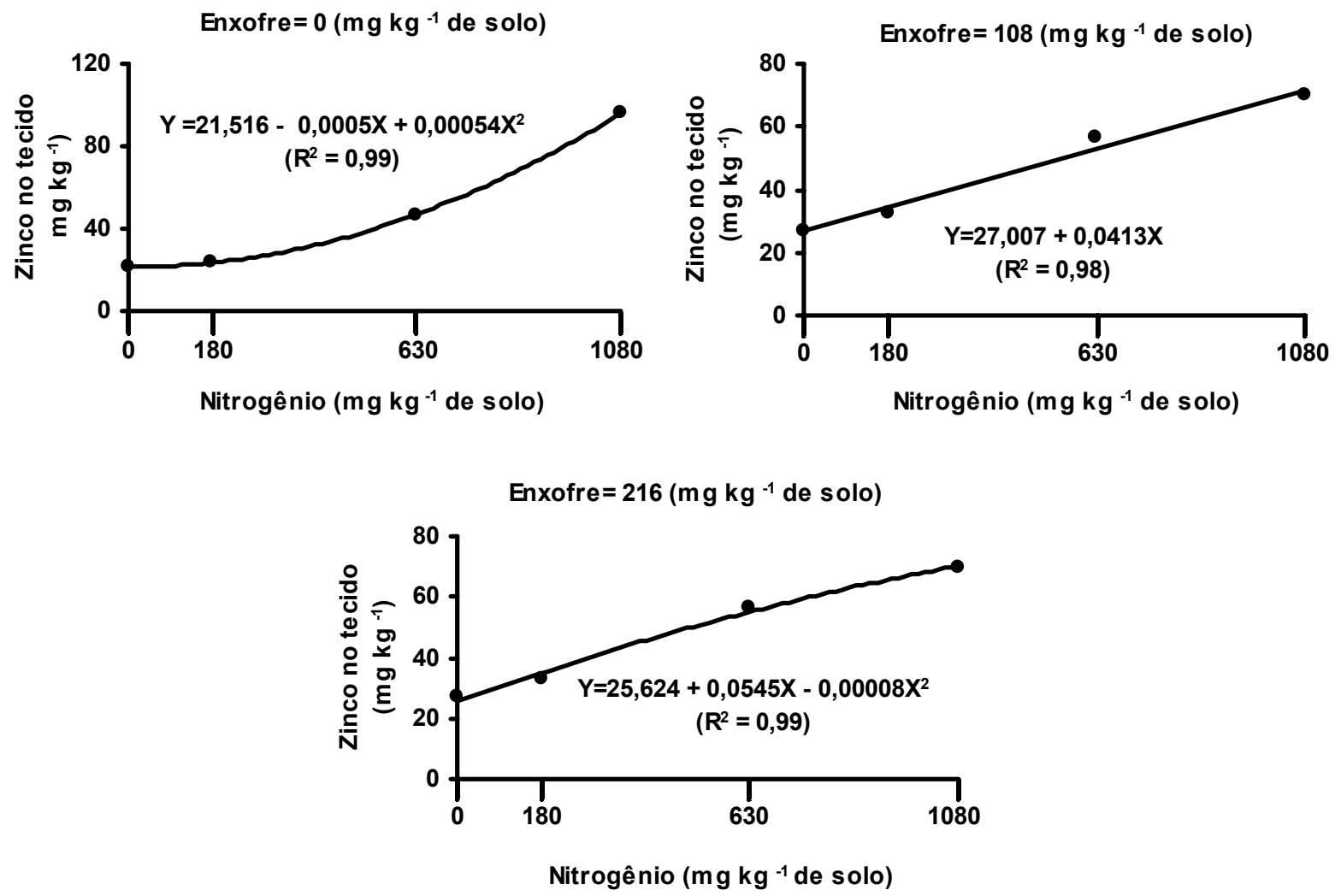

Figura 116 - Concentração de zinco no tecido das lâminas de folhas recém expandidas da Brachiaria decumbens, no segundo corte, em função das doses de nitrogênio dentro de cada dose de enxofre.

As lâminas de folhas maduras, apresentaram efeitos significativos $(P<0,05)$ para as doses de calcário, no primeiro e segundo cortes (Figura 117). Esses efeitos foram representados por um modelo linear, nos dois casos. No segundo corte, houve significância $(P<0,05)$ para as doses de nitrogênio que, tiveram ajustes a um modelo linear, nos dois casos (Figura118). 


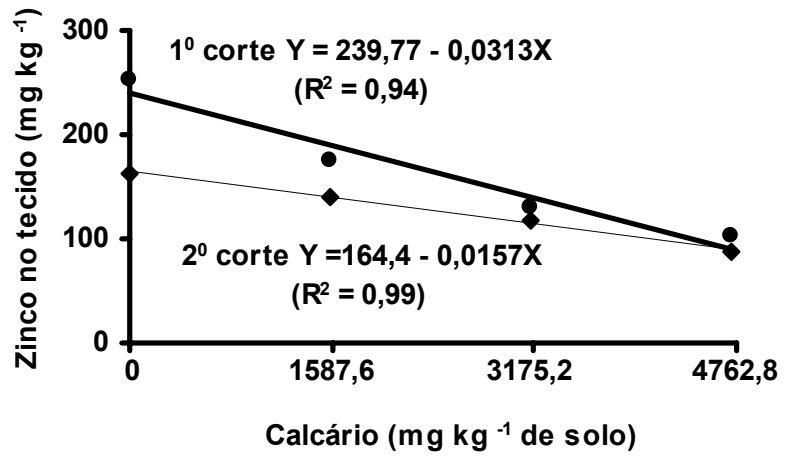

Figura 117 - Concentração de zinco no tecido das lâminas de folhas maduras da Brachiaria decumbens, no primeiro e segundo cortes, em função das doses de calcário.

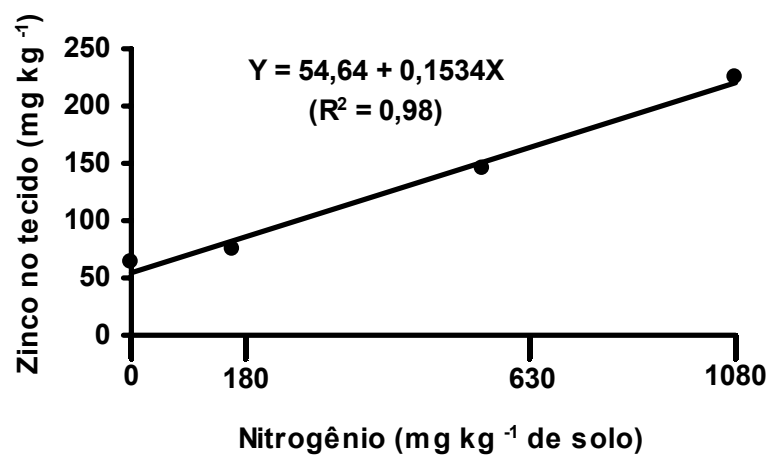

Figura 118 - Concentração de zinco no tecido das lâminas de folhas maduras da Brachiaria decumbens, no segundo corte, em função das doses de nitrogênio.

No segundo corte, houve significância $(P<0,05)$ para a interação entre doses de enxofre e nitrogênio. No estudo das doses de enxofre dentro das doses de nitrogênio, apenas a dose 0 e $1080 \mathrm{mg} \mathrm{kg}^{-1}$ de solo, foram significativas $(P<0,05)$. Os resultados ajustaram-se a um modelo quadrático na dose 0 , com ponto de máxima obtido em $110 \mathrm{mg} \mathrm{kg}^{-1}$ de solo e a um modelo linear na dose $1080 \mathrm{mg} \mathrm{kg}^{-1}$ de solo(Figura 119). Na avaliação das doses de nitrogênio dentro de cada doses de enxofre, verificou-se que, todas as doses 
foram significativas (Figura 120). Em todos os casos os valores seguiram a um modelo linear.
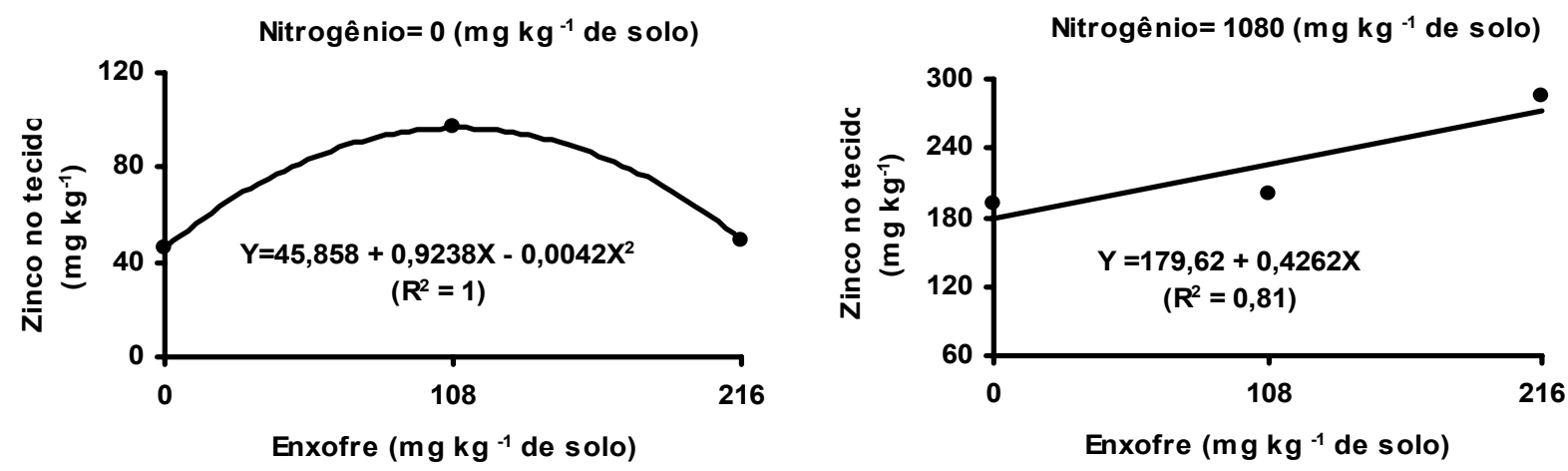

Figura 119 - Concentração de zinco no tecido das lâminas de folhas maduras da Brachiaria decumbens, no segundo corte, em função das doses de enxofre dentro das doses de nitrogênio 0 e $1080 \mathrm{mg} \mathrm{kg}^{-1}$ de solo.
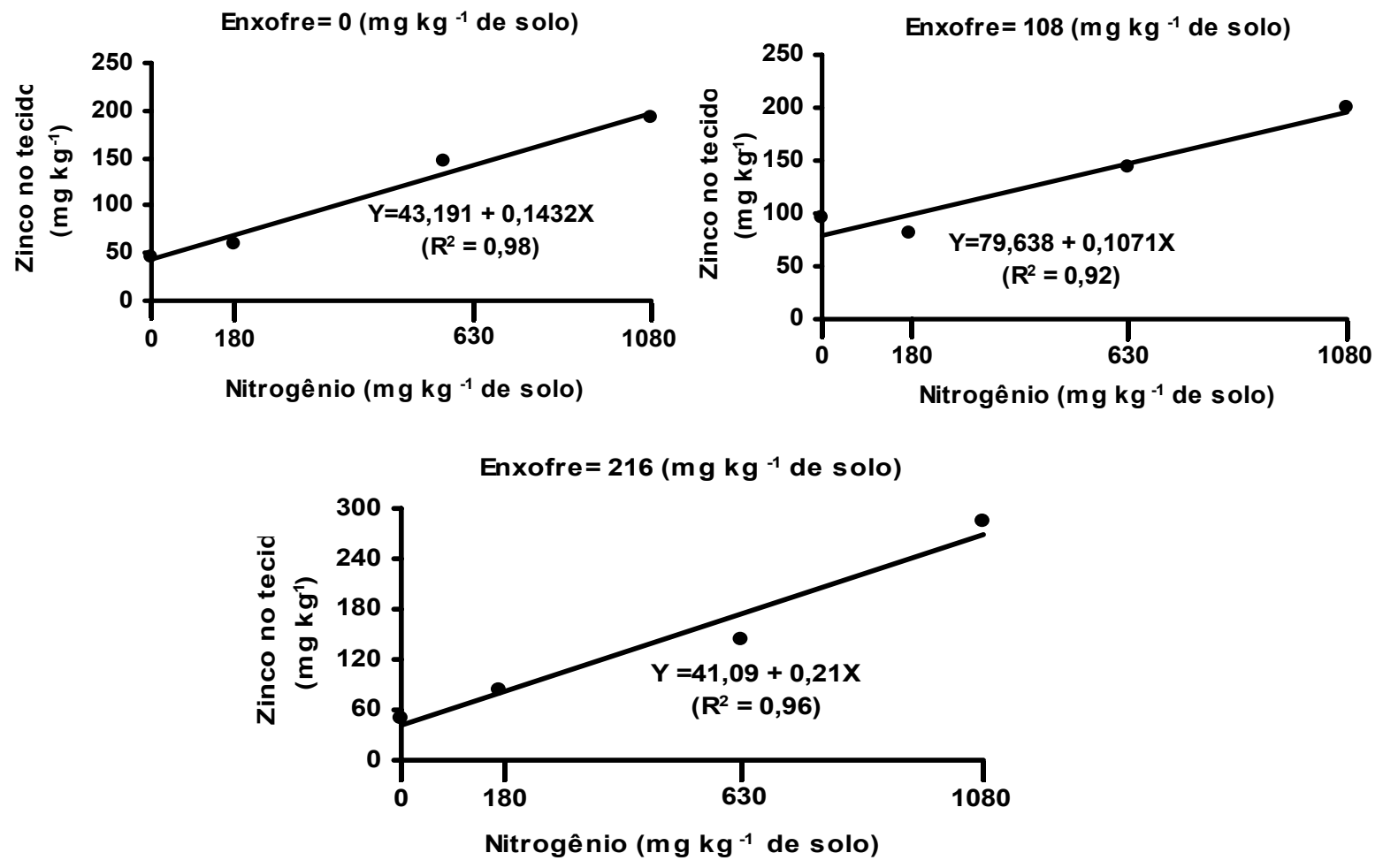

Figura 120 - Concentração de zinco no tecido das lâminas de folhas maduras da Brachiaria decumbens, no segundo corte, em função das doses de nitrogênio dentro de cada dose de enxofre. 
A análise de variância dos colmos mais bainhas, revelou significância $(P<0,05)$ para as doses de nitrogênio e calcário, no primeiro e segundo cortes. As doses de nitrogênio tiveram ajuste a um modelo quadrático com o ponto de máxima obtido na dose $856 \mathrm{mg} \mathrm{kg}^{-1}$ de solo, no primeiro corte e a um modelo linear, no segundo corte (Figura 121). As doses de calcário se ajustaram a um modelo linear, nas duas avaliações (Figura 122).

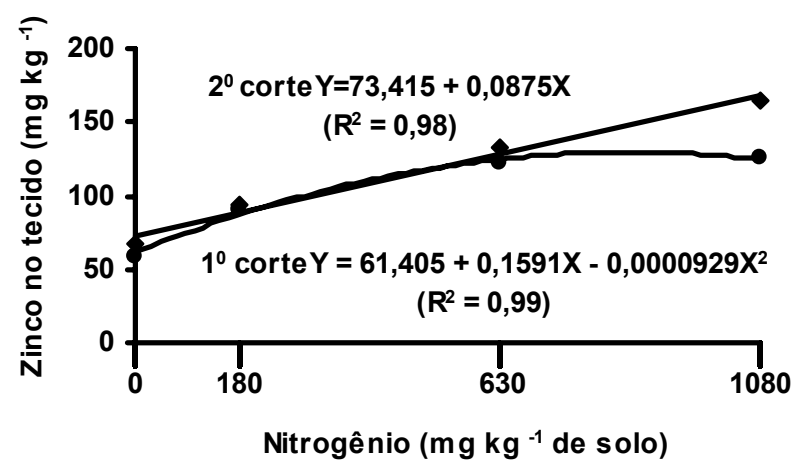

Figura 121 - Concentração de zinco no tecido dos colmos mais bainhas da Brachiaria decumbens, no primeiro e segundo corte, em função das doses de nitrogênio.

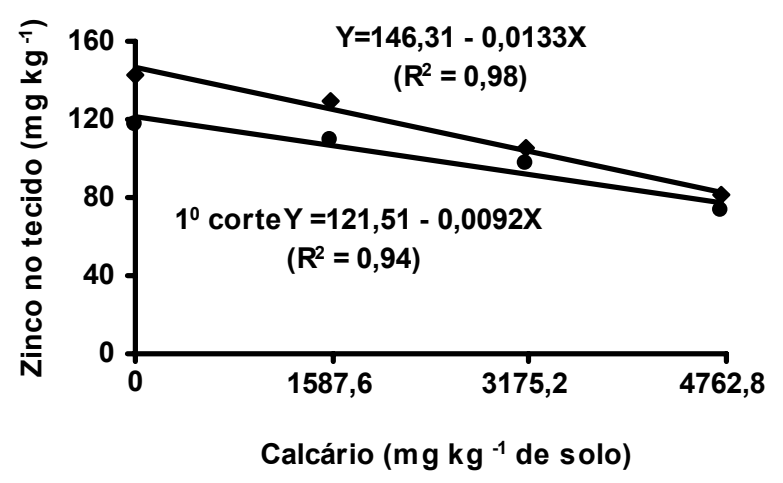

Figura 122 - Concentração de zinco no tecido dos colmos mais bainhas da Brachiaria decumbens, no primeiro e segundo corte, em função das doses de calcário. 
Os teores de zinco no tecido das plantas, estão nos padrões adequados para o animal de acordo com alguns autores e próximos dos encontrados por Gallo et al. (1974) que, observaram valores compreendidos na faixa de 20 à 80 ppm na maior parte das forrageiras analisadas. 


\section{CONCLUSÕES}

A partir dos resultados obtidos, as seguintes conclusões puderam ser formuladas:

O nitrogênio foi o nutriente que mais influenciou nos fatores analisados, comprovando sua essencialidade na recuperação de pastagens degradadas.

O enxofre também é um elemento indispensável, pois como foi observado neste estudo, a maior produção de matéria seca ocorreu nas doses mais elevadas de enxofre, principalmente nas maiores doses de nitrogênio. Além disso, ele influencia no teor de clorofila, perfilhamento e na concentração de nutriente nos tecidos das plantas, o que demonstra a importância do equilíbrio entre esses dois elementos no solo e na planta.

Por sua vez, o fornecimento de alguns nutrientes através da calagem possibilita incremento no perfilhamento, área foliar e na concentração de nutrientes nos tecidos das plantas.

O uso dessas informações isoladas ou em conjunto devem ser consideradas na recuperação de pastagens degradadas de capim-braquiária, nesse tipo de solo. 


\section{REFERÊNCIAS BIBLIOGRÁFICAS}

ALCÂNTARA, P. B. Origem das braquiárias e suas características morfológicas de interesse forrageiro. In: ENCONTRO PARA DISCUSSÃO DOS CAPINS DO GÊNERO BRACHIARIA, Nova Odessa, 1986. Anais. Nova Odessa: Instituto de Zootecnia, 1987. p.1-14.

ALVIM, M. J.; BOTREL, M. A.; VERNEQUE, R. S. Aplicação de nitrogênio em acessos de Brachiaria. 1. Efeito sobre a produção de matéria seca. Pasturas Tropicales, v. 12, n.2, p. 2-6, ago. 1990.

BENETTI, I.; MONTEIRO, F.A. Doses de potássio na produção e composição química do capim-Vencedor. In: SIMPÓSIO DE INICIAÇÃO CIENTÍFICA DA UNIVERSIDADE DE SÃO PAULO, Piracicaba, 1999. Resumos. São Paulo: Universidade de São Paulo, 1999. p.314.

BLACKMER, T.M.; SCHEPERS, J.S.; VARVEL, G.E. Light reflectance compared with other nitrogen stress measurements in corn leaves. Agronomy Journal, v.86, n.6, p.934-938, 1994.

BLASER, R.E; HAMMES Jr., R.C; FONTENOT, J. P.et al. Forage animal management systems. Backbsurg: Virginia Agricultura Experimental Station, 1986. 90 p. (Bulletin, 86-7) 
BOTREL, M. A.; ALVIM, M. J.; MARTINS, Y. Aplicação de nitrogênio em acessos de Brachiaria. 2.Efeitos sobre os teores de proteína bruta e minerais. Pasturas Tropicales, v.12, n.2, p. 7-10, 1990.

CARVALHO, M. M.; MARTINS, C. E; VERNEQUE, R S. et al. Resposta de uma espécie de Brachiaria à fertilização com nitrogênio e potássio em um solo ácido. Revista Brasileira de Ciência do Solo, v. 15, n. 2, p. 195-200, maio/ago. 1991.

CASAGRANDE, J. C.; SOUZA, O. L. Efeitos de níveis de $S$ sobre quatros gramíneas forrageiras tropicais em solo sob vegetação de cerrado do Mato Grosso do Sul, Brasil. Revista Agropecuária Brasileira, v.17, n.1, p.21-25, 1982.

CENTRO INTERNACIONAL DE AGRICULTURA TROPICAL. Informe anual. 1978: programa de ganado de carne. Cali, 1978. p. B86-B104: Fertilidade del suelo y nutrición de la planta.

COLOZZA, M. T. Rendimento e diagnose foliar dos capins Aruana e Mombaça cultivados em Latossolo-Amarelo adubado com doses de nitrogênio. Piracicaba, 1998. 127p. Tese (Doutorado) - Escola Superior de Agricultura "Luiz de Queiroz", Universidade de São Paulo.

CORREIA, A. A. D. Bioquímica nos solos, pastagens e forrageiras. Lisboa: Fundação Calouste Gulbenian, 1981. 787 p. 
CORSI, M; NASCIMENTO Jr., D. Princípios de fisiologia e morfologia de plantas forrageiras aplicados no manejo das pastagens. In: PEIXOTO, A. M.; MOURA, J. C. de; FARIA, V. P. de. (Ed.) Pastagens: fundamentos da exploração racional. Piracicaba: FEALQ, 1986. p.11-37.

DEFELIPO, B. V. Reação do solo/ correção da acidez do solo. In: UNIVERSIDADE FEDERAL DE VIÇOSA. SOL-370: Química e fertilidade do solo. Viçosa, 1990. p.73-117.

De-POLLI, H.; ALMEIDA, D. L.; FREIRE, L. R. Manual de adubação para o Rio de Janeiro. Itaguaí: Ed. UFRRJ,1988. 179 p.

EMPRESA BRASILEIRA DE PESQUISA AGROPECUÁRIA. Sistema Brasileiro de Classificação de solos. Rio de Janeiro: EMBRAPA/ Centro Nacional de Pesquisa de Solos., quinta aproximação. 1999. 171 p.

FAQUIN, V.; HOFFMANN, C. R.; EVANGELISTA, A. R. et al. O potássio e o enxofre no crescimento da braquiária e do colonião em amostras de um latossolo da região noroeste do Paraná. Revista Brasileira de Ciência do Solo, v.19, n.1, p.87-94, jan./abr. 1995.

FERNANDES, M. S.; ROSSIELO, R. O. P. Aspectos do metabolismo e utilização do nitrogênio em gramíneas tropicais. In: SIMPÓSIO SOBRE CALAGEM E ADUBAÇÃO DE PASTAGENS,1.,Nova Odessa, 1985. Anais. Piracicaba: POTAFOS, 1986. p. 93-123.

FERRAGINE, M. Combinação de doses de nitrogênio e potássio na nutrição mineral de capim-braquiária. Piracicaba, 1998. 84p. Dissertação (Mestrado) - Escola Superior de Agricultura "Luiz de Queiroz", Universidade de São Paulo. 
FERRAGINE, M. C.; MONTEIRO, F.A. Combinação de doses de nitrogênio e potássio na nutrição mineral de capim-braquiária. Boletim de Indústria Animal, v.56, n.1, p.25-33, 1999.

FERRARI Jr, E.; ANDRADE, J.B; PEDREIRA, J. V.S.; CONSENTINO, J. R.; SCHAMMASS, E. A. Produção de feno de Brachiaria decumbens e Brachiaria brizantha cv. Marandu sob três frequências de corte. 1. Produção de matéria. Boletim de Indústria Animal, v.51, n. 1, p. 49-54, 1994.

FOX, R.H.; PIEKIELEK, W. P.; MACNEAL, K. M. Using a chorophyll meter to predict nitrogen fertilizer needs of winter wheat. Communications in Soil Science and Plant Analysis, v.25, n.3/4, p.171-181, 1994.

GALLO, J.R.; HIROCE, R.; BATAGLIA, O.C. et al. Composição química inorgânica de forrageiras do Estado de São Paulo. Boletim de Indústria Animal, v. 31, n.1, p.115-137, 1974.

GASTAL, F.; LEMAIRE, G. Study of a tall fescue sward under nitrogen deficiency conditions. In: GENERAL MEETING OF THE EUROPEAN GRASSLAND FEDERATION, 12., Dublin, 1988. Proceedings. Dublin, 1988, p. 323-327.

GASTAL, F.; BELANGER, G.; LEMAIRE, G. A model of the leaf extention rate of tall fescue in response to nitrogen and temperature. Annals of Botany, v.70. n.5, p.437-442, 1992.

GASTAL, F.; NELSON, C.J. Nitrogen use withing the growing leaf blade of tall fescue. Plant Physiology, v. 105, n.1, p. 191-197, 1994. 
GUIMARÃES, T.G.; FONTES, P.C.R.; PEREIRA, P.R.G. et al. Teores de clorofila determinados por medidor portátil e sua relação com formas de nitrogênio em folhas de tomateiro cultivados em dois tipos de solos. Bragantia, v.58, n.1, p. 209-216, 1999.

HADDAD, C. M. Efeito do enxofre aplicado na forma de gesso, sobre a produção e qualidade do capim colonião ( Panicum maximum Jacq.). Piracicaba, 1983. 115 p. Tese (Doutorado). Escola Superior de Agricultura "Luiz de Queiroz", Universidade de São Paulo

HARDING, W. A. T., GROF, B. Effect of fertilizer nitrogen on yield, nitrogen content and animal productivity of Brachiaria decumbens cv. Basilisk on the wet tropical coast of North Queensland. Queensland Journal of Agricultural and Animal Sciences, v. 35, n.1, p.11-21, 1978.

HERNANDEZ, M.; CARDENAS, M. Respuesta del pasto estrella jamaicano a niveles de NPK en un suelo ferralítico cuarcítico. Pastos y Forrajes, v. 13, p.237-277, 1990.

HOEL, B.; SOLHAUG, K.A. Effect of irradiance on chlorophyll estimation with the Minolta SPAD-502 leaf chlorophyllmetre. Annals of Botany, v.82, n.3, p.389-392, 1998.

HOFFMANN, C.R. Nutrição mineral e crescimento da braquiária e do colonião, sob influência das aplicações de nitrogênio, fósforo, potássio e enxofre em Latossolo da Região Noroeste do Paraná. Lavras, 1992. 204p. Dissertação (Mestrado) - Escola Superior de Agricultura de Lavras. 
HOFFMANN, C.R.; FAQUIN, V.; GUEDES, G.A.A. et al. O nitrogênio e o fósforo no crescimento da braquiária e colonião em amostras de um latossolo da região noroeste do Paraná. Revista Brasileira de Ciência do Solo, v.19, n. 1, p.79-86, 1995.

HUMPHRIES, E.C.; WHEELER, A.W. The physiology of leaf growth. Annual Review of Plant Physiology, v.45, p.385-405, 1963.

KANTETY, R. V.; SANTEN, E. van; WOODS, F. M. et al. Chlorophyll meter predicts nitrogen status of tall fescue. Journal of Plant Nutrition, v.19, n. 6, p. 881-899, 1996.

LANGER, R.H.M. Tillering in herbage grasses. Herbage Abstracts, v.33, n.3, p.141-148, 1963.

LAVRES Jr. J. Combinações de doses de nitrogênio e potássio para o capimMombaça. Piracicaba, 2001. 103 p. Dissertação (Mestrado) - Escola Superior de Agricultura "Luiz de Queiroz", Universidade de São Paulo.

LOPES, A. Solos "sob condições de cerrados": características, propriedades e manejo. Piracicaba: Associação Brasileira para Pesquisa de Potassa e do Fosfato, 1984. 162p.

MALAVOLTA, E. Elementos de nutrição mineral de plantas. São Paulo: Agronômica Ceres, 1980. 251 p.

MALAVOLTA; E., VITTI, G. C.; OLIVEIRA, S. A. de Avaliação do estado nutricional das plantas. Piracicaba: POTAFOS, 1989. 201p. 
MALAVOLTA, E.; VITTI, G.C.; OLIVEIRA, S.A. de. Avaliação do estado nutricional de plantas: princípios e aplicações. 2.ed. Piracicaba: Associação Brasileira para Pesquisa de Potassa e do Fosfato, 1997. 319p.

MANARIN, C.A. Respostas fisiológicas, bioquímicas e produtivas do capimMombaça a doses de nitrogênio. 2000. 58p. Dissertação (Mestrado) Escola Superior de Agricultura "Luiz de Queiroz", Universidade de São Paulo.

MARSCHNER, H. Mineral nutrition in higher plants. Berlin: Academic Press, 1995. $674 \mathrm{p}$.

MARTIM, R. A. Doses de nitrogênio e de potássio para produção e composição dos capins Coastcross e Tifto 85 em um Latossolo Vermelho-Amarelo.. Piracicaba, 1997. 109p. Dissertação (Mestrado) - Escola Superior de Agricultura "Luiz de Queiroz", Universidade de São Paulo.

MARTINS SOBRINHO, E. O. Efeitos de tipos e doses de calcário em pastagens de tobiatã (Panicum maximum Jacq.). Pirassununga, 1997. 54 p. Dissertação (Mestrado) - Faculdade de Zootecnia e Engenharia de Alimentos, Universidade de São Paulo.

MARUN, F. Produção de matéria seca e nutrição mineral de gramíneas forrageiras em função da relação Ca/Mg do corretivo. Lavras, 1990. 81p. Dissertação (Mestrado) - Escola Superior de Agricultura de Lavras.

MATTOS, W.T. Diagnose nutricional de potássio em duas espécies de Braquiária. Piracicaba, 1997. 74p. Dissertação (Mestrado) - Escola Superior de Agricultura "Luiz de Queiroz”, Universidade de São Paulo. 
MATTOS, W.T. Avaliação de pastagem de capim-braquiária em degradação e sua recuperação com suprimento de nitrogênio e enxofre. Piracicaba, 2001. 94p. Tese (Doutorado) - Escola Superior de Agricultura "Luiz de Queiroz", Universidade de São Paulo.

MAZZANTI, A.; LEMAIRE, G. Effect of nitrogen fertilization on the herbage production of tall fescue swards grazed continuously with sheep. 2 . Comsumption and efficiency of herbage utilisation. Grass and Forage Science, v. 49, n.2, p. 352-359, 1994.

MENGEL, K; KIRKBY, E. A. Principles of plant nutrition. 4.ed. Bern: International Potash Institut, 1987. 687p.

MILFORD, R.; MINSON, S. J. The relation between the crude protein content of tropical pasture plants. Journal of the Bristish Grassland Society, v. 20, n. 3, p. 1977-1979, Sept. 1965.

MINOLTA CAMERA. Manual for chlorophyll meter SPAD-502. Osaka, 1989. $22 \mathrm{p}$.

MINOTTI, P. L.; HALSETH, D. E.; SIECZKA, J.B. Field chlorophyll measurements to assess the nitrogen status of potato varieties. HortScience, v.29, n.12, p.1497-1500, 1994.

MITIDIERI, F. J. Níveis de calcário em cinco gramíneas forrageiras cultivadas em solo de cerrado. Piracicaba, 1995. 156 p. Dissertação (Mestrado) Escola Superior de Agricultura "Luiz de Queiroz", Universidade de São Paulo. 
MONTEIRO, F. A.; CARRIEL, J.M. Aplicação de níveis de enxofre na forma de gesso para cultivo do capim colonião em dois solos arenosos do Estado de São Paulo. Boletim de Industria Animal, v. 44, n.2, p.335-347, 1987.

MONTEIRO, F.A.; RAMOS, A.K.B.; CARVALHO, D.D. et al. Cultivo de Brachiaria brizantha Stapf. cv. Marandu em solução nutritiva com omissões de macronutrientes. Scientia Agricola, v.52, n.1, p.135-141, 1995.

NABINGER, C. Eficiência do uso de pastagens: disponibilidade e perdas de forragem. In: SIMPOSIO SOBRE MANEJO DA PASTAGEM, 14., Piracicaba, 1997. Anais. Piracicaba: FEALQ, 1997. p.213-251.

NEILSEN,D.; HOGUE, E.L.; NEILSEN, G.H et al. Using SPAD-502 to assess the nitrogen status of apple trees. HortScience, v.30, n.3, p.508-512, 1995.

OLIVEIRA, M. A. Estudo de crescimento e valor nutritivo do capim brachiaria ( $B$. decumbens Stapf). Piracicaba, 1980. 68 p. Dissertação (Mestrado) - Escola Superior de Agricultura "Luiz de Queiroz" Universidade de São Paulo.

PAULINO, V.T.; SCHUNKE, R.; CANTARELLA, H. Avaliação do nível de nitrogênio em quatro cultivares de Panicum maximum Jacq. através da medida indireta de clorofila. In: REUNIÃO ANUAL DA SOCIEDADE BRASILEIRA DE ZOOTECNIA, 35., Botucatu, 1998. Anais. Botucatu: Sociedade Brasileira de Zootecnia, 1998. p. 508-511.

PEARSE, P.J.; WILMAN, D. Effects of applied nitrogen on grass leaf initiation, development and death in field swards. Journal of Agricultural Science, v.103, n.2, p.405-413, 1984. 
PEREIRA, J. P. Adubação de capins do gênero Brachiaria. In: ENCONTRO SOBRE CAPINS DO GÊNERO Brachiaria, 1., Nova Odessa, 1986. Anais. Nova Odessa: Instituto de Zootecnia, 1986. p.1-96.

PIEKIELEK, W.P.; FOX, R.H. Use of chlorophyll meter to predict sidedress nitrogen requirements for maize. Agronomy Journal, v.84, n.1, p.59-65, 1992.

PINTO, J.C.; GOMIDE, J.A.; MAESTRI, M. et al. Crescimento de folhas de gramíneas forrageiras tropicais, cultivadas em vasos, com duas doses de nitrogênio. Revista da Sociedade Brasileira de Zootecnia, v. 23, p. 327332, 1994.

PREMAZZI, L. M. Saturação por bases como critério para recomendação de calagem em cinco forrageiras tropicais. Piracicaba, 1991. 215 p. Dissertação (Mestrado) - Escola Superior de Agricultura "Luiz de Queiroz", Universidade de São Paulo.

PREMAZZI, L. Crescimento do capim-tifton 85 submetido a doses e épocas de aplicação de nitrogênio após o corte. Piracicaba, 2001. 93 p. Tese (Doutorado) - Escola Superior de Agricultura "Luiz de Queiroz", Universidade de São Paulo.

QUAGGIO, J. A. Reação do solo e seu controle. In: SIMPÓSIO AVANÇADO DE QUÍMICA E FERTILIDADE DO SOLO, Campinas, 1986. Anais. Campinas: Fundação Cargil,1986. p. 53-89.

RAIJ, B. van. Avaliação da fertilidade do solo. Piracicaba: Instituto da Potassa e Fosfato, 1981. 142 p. 
RAIJ, B. van.; QUAGGIO, J. A. Uso eficiente de calcário e gesso na agricultura. In: SIMPÓSIO SOBRE FERTILIZANTES NA AGRICULTURA, Brasília, 1984. Anais...Brasília: EMBRAPA-DEP, 1984. p.323-346.

SANTOS, A. R. dos. Diagnose nutricional e respostas do capim braquiária submetido a doses de nitrogênio e enxofre. Piracicaba, 1997. 115 p. Dissertação (Mestrado) - Escola Superior de Agricultura "Luiz de Queiroz", Universidade de São Paulo.

SANZONOWICZ, C. Recomendação e prática de adubação e calagem na região centro-oeste do Brasil. In: SIMPÓSIO SOBRE CALAGEM E ADUBAÇÃO DE PASTAGENS, 1., Nova Odessa, 1985. Anais. Piracicaba: Associação Brasileira para a Pesquisa da Potassa e do Fosfato, 1986. p. 309-336.

SANZONOWICZ, C.; LOBATO, E.; GOEDERT, W. J. Efeito residual de calagem e de fonte de fósforo numa pastagem estabelecida em solo de cerrado. Pesquisa Agropecuária Brasileira, v. 22, n. 3, p. 233-43, 1987.

SARRUGE, J.R.; HAAG, H.P. Análises químicas de planta. Piracicaba: ESALQ, 1974. 56p.

SAS INSTITUTE. The SAS-system for windows: release 6.11 (software). Cary, 1996.

SIQUEIRA, C.; CARVALHO, M. M.; SARAIVA, O. F. et al. Resposta de três gramíneas forrageiras tropicais à aplicação de calcário e fósforo em solo ácido. In: REUNIÃO ANUAL DA SOCIEDADE BRASILEIRA DE ZOOTECNIA, 17., Fortaleza, 1980. Anais. Fortaleza: SBZ, 1980. p. 473. 
SOARES FILHO, C. V.; MONTEIRO, F. A.; CORSI, M. Recuperação de pastagens degradadas de Brachiaria decumbens. 1. Efeito de diferentes tratamentos de fertilização e manejo. Pasturas Tropicales, v. 14, n. 2, p.16, ago. 1992.

SOARES FILHO, C. V. Variação sazonal de parâmetros bioquimicos-fisiológicos em Brachiaria decumbens estabelecida em pastagens. Piracicaba, 1991. 110 p. Dissertação (Mestrado)- Escola Superior de Agricultura "Luiz de Queiroz", Universidade de São Paulo.

TAIZ, L.; ZEIGER, E. Plant physiology. Redwood City: The Benjamin/Cumminggs, 1991. cap. 12, p. 292-317.

TURNER, F.T.; JUND, M.F. Chlorophyll meter to predict nitrogen topdress requirement for semidwarf rice. Agronomy Journal, v.83, n.1, p.926-928, 1991.

VICENTE-CHANDLER, J. Intensive grassland management in Puerto Rico. Revista da Sociedade Brasileira de Zootecnia, v. 2, n.1, p. 173-215, 1973.

VICENTE-CHANDLER, J.; SILVA, S.; ABRUNÃ, F. et al. Effect of two cutting heights, four harvest intervals and five nitrogen rates on yield and composition of Congo Grass under humic tropical conditions. Journal of Agriculture of University of Puerto Rico, v.56, n.3, p.280-291, 1972.

VITTI, G. C.; LUZ, P. H. de C. Calagem e uso de gesso agrícola em pastagens. In: SIMPÓSIO SOBRE ECOSSISTEMA DE PASTAGENS, 10., Jaboticabal, 1997. Anais Jaboticabal: UNESP/ FCAJ,1997. p.63-111. 
VITTI, G. C.; NOVAES, N. J. Adubação com enxofre. In: SIMPÓSIO SOBRE CALAGEM E ADUBAÇÃO DE PASTAGENS, 1., Nova Odessa, 1985. Anais. Piracicaba: Associação Brasileira para a Pesquisa da Potassa e do Fosfato, 1986. p.191-231.

WERNER, J.C. Adubação de pastagens. Nova Odessa: Instituto de Zootecnia, 1986. 49 p. (IZ. Boletim Técnico, 18).

WERNER, J. C.; HAAG, H. P. Estudos sobre a nutrição mineral de alguns capins tropicais. Boletim de Indústria Animal, v.29, n.1, p.191-245, 1972.

WERNER, J. C.; MONTEIRO, F. A. Respostas das pastagens à aplicação de enxofre. In: SIMPÓSIO SOBRE ENXOFRE E MICRONUTRIENTES NA AGRICULTURA BRASILEIRA, Londrina, 1988. Anais. Londrina: EMBRAPA, CNPS; IAPAR, 1988. p. 87-102.

WHITEHEAD, D. C.; Grassland nitrogen. Wallingford: CAB International, 1995. $397 \mathrm{p}$.

WILMAN, D.; PEARSE, P. J. Effects of applied nitrogen on grass yield, nitrogen content, tillers and leaves in field swards. Journal of Agricultural Science, v. 103, p. 201-211, 1984. 